\title{
AUGUSTINE AND THE ART OF RULING IN THE CAROLINGIAN IMPERIAL PERIOD
}

\section{POLITICAL DISCOURSE IN ALCUIN OF YORK AND HINCMAR OF RHEIMS}

Sophia Moesch 


\section{Augustine and the Art of Ruling in the Carolingian Imperial Period}

This volume is an investigation of how Augustine was received in the Carolingian period, and the elements of his thought which had an impact on Carolingian ideas of 'state', rulership and ethics. It focuses on Alcuin of York and Hincmar of Rheims, authors and political advisers to Charlemagne and to Charles the Bald, respectively. It examines how they used Augustinian political thought and ethics, as manifested in the De civitate Dei, to give more weight to their advice. A comparative approach sheds light on the differences between Charlemagne's reign and that of his grandson. It scrutinizes Alcuin's and Hincmar's discussions of empire, rulership and the moral conduct of political agents during which both drew on the De civitate Dei, although each came away with a different understanding. By means of a philological-historical approach, the book offers a deeper reading and treats the Latin texts as political discourses defined by content and language.

Sophia Moesch is currently an SNSF-funded postdoctoral fellow at the University of Oxford, working on a project entitled 'Developing Principles of Good Governance: Latin and Greek Political Advice during the Carolingian and Macedonian Reforms'. She completed her PhD in History at King's College London. 
$\Longrightarrow$ Taylor \& Francis Taylor \& Francis Group http://taylorandfrancis.com 


\section{Augustine and the Art of Ruling in the Carolingian Imperial Period}

Political Discourse in Alcuin of York and Hincmar of Rheims

Sophia Moesch 
First published 2020

by Routledge

2 Park Square, Milton Park, Abingdon, Oxon OX14 4RN

and by Routledge

52 Vanderbilt Avenue, New York, NY 10017

Routledge is an imprint of the Taylor \& Francis Group, an informa business

Published with the support of the Swiss National Science Foundation.

(C) 2020 Sophia Moesch

The right of Sophia Moesch to be identified as author of this work has been asserted by her in accordance with sections 77 and 78 of the Copyright, Designs and Patents Act 1988.

The Open Access version of this book, available at www.taylorfrancis.com, has been made available under a Creative Commons Attribution-Non Commercial-No Derivatives 4.0 license.

DOI: https://doi.org/10.4324/9781351116022

Trademark notice: Product or corporate names may be trademarks or registered trademarks, and are used only for identification and explanation without intent to infringe.

British Library Cataloguing-in-Publication Data

A catalogue record for this book is available from the British Library

Library of Congress Cataloging-in-Publication Data

A catalog record has been requested for this book

ISBN: 978-0-8153-6160-2 (hbk)

ISBN: 978-1-351-11602-2 (ebk)

Typeset in Times New Roman

by Deanta Global Publishing Services, Chennai, India 
"Caritas vero inter amicos melior est auro et fides inter absentes praetiosior gemmis"

- Alcuin of York, Epistle 76

Dedicated to Kurt, Rosmarie and Johanna Moesch, and Giovanni Trotto 
$\Longrightarrow$ Taylor \& Francis Taylor \& Francis Group http://taylorandfrancis.com 


\section{Contents}

Note on the text

$\mathrm{X}$

Acknowledgements $\quad \mathrm{xi}$

Abbreviations xiii

Introduction 1

Augustine and the Carolingians 1

Framing the enquiry 3

A philological-historical approach to the sources 5

'State-church' relations in late antiquity and the Early Middle Ages 8

Notes 11

Bibliography 14

\section{PART I}

Augustine of Hippo

1 Influences on the De civitate Dei

Historical and cultural context 21

Biographical aspects 22

Authorities and movements 22

Marcus Tullius Cicero 23

Notes 25

Bibliography 30

2 Augustine's stance on worldly rule and his assessment of politically organised communities in the De civitate Dei

Notes 41

Bibliography 44

3 Concepts of Augustinian political thought

Terminology for types of politically organised communities 46

Dispensatio 52 
viii Contents

Felix/felicitas and beatus/beatitudo 53

Iustitia and pax 54

Notes 57

Bibliography 64

\section{PART II}

Alcuin of York

4 Alcuin's direct use of Augustine in the 'Epistolae'

Alcuin's Epistle $307 \quad 70$

Comparison with other Epistles 73

Notes 76

Bibliography 78

5 Alcuin's indirect use of Augustine: His stance on worldly rule and recourse to Augustine's terminology

Alcuin on rulership and Roman emperors 82

Alcuin on rulership and Old Testament kings 86

Alcuin's use of Augustinian vocabulary 93

Civitas Dei 94

Dispensatio 96

Imperium and gentes 101

Notes 114

Bibliography 127

\section{PART III}

Hincmar of Rheims

6 Hincmar's direct use of Augustine in the 'Epistolae'

Hincmar's Epistle 99137

Hincmar's Epistles 179, 28, 37 and 48144

Hincmar's Epistles 134 and 108148

Notes 153

Bibliography 162

7 Hincmar's indirect use of Augustine: His 'Expositiones ad Carolum Regem' and 'De regis persona et regio ministerio'

Hincmar's Expositiones ad Carolum Regem 165

Hincmar's De regis persona et regio ministerio 182

Cicero 201

Augustine 201 
Alcuin 204

Hincmar 206

Notes 210

Bibliography 220

\section{Conclusion}

223

Carolingian political thought c. 800-c. 900224

Alcuin's and Hincmar's uses of Augustine in the light of changing 'state-church' relations 225

Notes 231

Bibliography 234

Index 


\section{Note on the text}

This book refers to many primary sources, most of which are in Latin. Citations in the main text from Latin (or, occasionally, Greek) material are given in English translation, which is my own unless otherwise indicated. The original text is given in the endnotes. Wherever I draw significantly on primary sources without quoting them in the body of the text, I provide the excerpts in the endnotes in the original language. Paragraph breaks in all quotations correspond to the original text (as rendered in the editions I adhere to). 


\section{Acknowledgements}

Many have contributed to this book, which is the culmination of four years of research into the reception of Augustine of Hippo's political thought and ethics in the Carolingian era. In the autumn of 2010, I embarked on a $\mathrm{PhD}$ in England at King's College London. I am grateful to my supervisors Peter Heather and Alice Rio for accepting my proposal from abroad, to KCL for providing the infrastructure for completing such a formidable task, and to the Swiss National Science Foundation for awarding me with a Doc.Mobility fellowship.

Several people have read the drafts of my doctoral dissertation. Thanks to Julia Crick for identifying weaknesses and options for improvement in my chapter on Alcuin of York, for encouraging my enthusiasm for palaeography and, last but not least, for encouraging me to give my first paper at Revealing Records V; to Daniel Hadas for his kind assistance with my translations of Latin passages from Alcuin and Augustine; to Carsten Schmieder for providing me with a second opinion on an intricate passage in Hincmar of Rheims' Expositiones ad Carolum Regem; and to Sarah Sharp for her excellent proofreading work.

To other people I owe a lot for helping me to develop my academic skills and specialisation. Thanks to Janet Coleman (London School of Economics) and Stefan Rebenich (University of Bern) for encouraging me to pursue research in the reception of late antique political thought; and to Achatz von Müller (University of Basel) for convening a seminar on Political Theories from Augustine to Machiavelli and for being my dissertation supervisor for the lic. phil. degree. At KCL, I am indebted to Edith Hall and Roland Mayer for welcoming me to their MA course on Hellenistic Poetry and for deepening my knowledge of ancient Greek literature, translation and interpretation; to Alessandra Bucossi, for piquing my interest in Greek Palaeography \& Textual Criticism; thanks also to Charalambos Dendrinos (Royal Holloway) for allowing me to participate in his Working Seminar on Editing Byzantine Texts at the Warburg. At the KCL Modern Language Centre, I owe thanks to Paolo Nelli and Amira Mills, who taught me Italian and Arabic. Last but not least, I would like to express my warmest thanks to Simon Sleight and Joe Maiolo who have been invaluable sources of support and advice during my time of teaching at KCL and LSE.

My friends and family have been with me all along this journey. The importance of their contribution is overshadowed only by their love and friendship. 


\section{xii Acknowledgements}

Thanks to Albertine Fox, Sakiko Kaiga and Kathrin Pavić for their continuing presence and unswerving positivity; and to Foteini Kanellopoulou, Evangelia Gioldasi and Eda Karaarslanoglu for being my family away from home. Two people have shaped my work and life significantly during the past years: Franziska Herzog and Martin Kaiser. Their human qualities have been decisive in leading me to where I am today. In particular, the brilliance of Martin Kaiser and his enthusiasm for classical and patristic ancient Greek and Latin texts were reasons, almost a decade ago, for me to embark on a $\mathrm{PhD}$ in late antique and early medieval history. I have benefited, in each of my chapters, from his unique gift for language and literary analysis, and he continues to inspire by his example and dedication to the moral values academic work can pursue. My deepest gratitude above all, of course, to my family - my parents, Kurt and Rosmarie Moesch, and sister, Johanna Moesch. I would also like to extend my love and wholehearted thanks to Giovanni Trotto, whose creative spirit and inexhaustible curiosity have never failed to enrich my explorations.

In the final stages of my work, I thank Routledge and all those who were involved in the production of my book. Above all my editors, Michael Greenwood and Dana Moss, deserve my grateful thanks for their expert work and careful guidance.

To all of you, my heartfelt thank you. 


\title{
Abbreviations
}

\author{
JThS Journal of Theological Studies \\ LLT-A Library of Latin Texts - Series A \\ MGH Monumenta Germaniae Historica. Series Latina by Jacques- \\ Paul Migne 217 vols. 1844-1855 + 4 index-vols. 1862-1865 \\ AN Poet. Lat. Antiquitates Poetae Latini aevi Carolini \\ Capit. Capitularia regum Francorum \\ Capit. N. S. Capitularia regum Francorum Nova Series \\ Conc. Concilia \\ Epp. $\quad$ Epistolae (in Quart) \\ Fontes iuris Fontes iuris Germanici antiqui in usum scholarum separatim editi \\ SS rer. Germ. Scriptores rerum Germanicarum in usum scholarum separatim \\ editi \\ SS rer. Merov. Scriptores rerum Merovingicarum \\ $P L$ \\ Patrologiae Cursus Completus. Series Latina by Jacques-Paul \\ Migne 217 vols. 1844-1855 + 4 index-vols. 1862-1865
}


$\Longrightarrow$ Taylor \& Francis Taylor \& Francis Group http://taylorandfrancis.com 


\section{Introduction}

\section{Augustine and the Carolingians}

Augustine of Hippo's De civitate Dei would seem, at first sight, an unpromising starting-point for rulers of "states" in search of ideological support, since - strictly and theoretically speaking - it ultimately predicts failure, whatever their earthly endeavours may be. Nevertheless, Charlemagne's imperial plan for a Carolingian 'state' and 'church' ${ }^{2}$ as well as his cultural reform ${ }^{3}$ have tempted historians to propose that his scheme involved the realisation of Augustine's civitas Dei. ${ }^{4}$ After all, Einhard maintains in his Vita Karoli Magni that the emperor particularly enjoyed listening to Augustine's De civitate Dei. ${ }^{5}$ However, although it may have become standard practice in medieval scholarship to relate the Carolingian empire to Augustine's civitas Dei, a thorough investigation of how Augustine was received in the Carolingian period, and the elements of his thought which had an impact on Carolingian ideas of 'state', rulership and ethics, is yet to be written. This book contributes towards such an endeavour. Since it is not possible in a monograph to explore Augustine's influence in all the surviving Carolingian texts, the book concentrates on two highly influential authors who lived at different points in time during the Carolingian empire: Alcuin of York and Hincmar of Rheims. The work explores the thinking and motives behind Alcuin's and Hincmar's recourse to Augustine's thought in their attempts to legitimate Carolingian rule, consolidate and maintain the empire - and to what extent these authors in fact used it. The research looks into how Augustine's ideas were understood, taken on and modified by Alcuin and Hincmar to serve the Carolingian imperial dynasty. ${ }^{6}$

No study has been undertaken in this area since the work of H.-X. Arquillière, published in the 1930s, which provides the dominant explanatory model of Augustine's reception in medieval political thought. ${ }^{7}$ His broad, overarching study argues that a certain form of political thought ${ }^{8}$ inspired by Augustine's De civitate Dei developed in Merovingian times, when kingship ${ }^{9}$ gradually began to be seen as subservient to the 'church'. ${ }^{10}$ The term Arquillière uses for this thought, which was diffused, for example, through the texts of Gregory the Great and Isidore of Seville, is Augustinisme politique ("political Augustinianism"). N. H. Baynes' research on the political ideas in the De civitate Dei, published two years later, does not advance Arquillière's research. ${ }^{11}$ However, Baynes 


\section{Introduction}

confirms that medieval authors, by concentrating on certain statements in isolation rather than in context, did derive political doctrine from this work. ${ }^{12}$ Before Arquillière, German scholarship (e.g. Dempf 1973; an unchanged fourth edition of the 1929 Sacrum Imperium) had suggested - without producing evidence that in the Carolingian period, Augustine's concept of the civitas Dei served as a model for the Carolingian 'state'. ${ }^{13}$ After Arquillière, the Belgian historian F. L. Ganshof indicated in The Imperial Coronation of Charlemagne (1949) that French scholars (e.g. A. Kleinclausz, L. Halphen and L. Levillain) had understood Charlemagne's empire as "a kind of prefiguration on earth of the city of God."14 Along with, for example, E. Patzelt and C. Vogel (1965),${ }^{15}$ and W. von den Steinen (1967), ${ }^{16}$ Ganshof argued that Charlemagne's advisers had attempted "to realise the 'Augustinian' conception of the city of God." ${ }^{17}$ While J. M. Wallace-Hadrill (1975; first published in 541965), ${ }^{18}$ F. Dvornik $(1966)^{19}$ and H. H. Anton $(1968)^{20}$ endorsed Arquillière's thesis concerning the development of Augustinisme politique in the Middle Ages, M. J. Wilks $(1967)^{21}$ attempted to invalidate it. Despite engagement with Arquillière, the question of Augustine's influence on Carolingian political thought and political ethics has not been at the forefront of recent historical research. R. A. Markus, in his study into Augustine's thought (1970), uses the phrase Augustinisme politique "in a very different sense from that given it by Arquillière," namely "to mean the political theory implied in Augustine's theology of the saeculum." 22 J. Boler (1978), in an article demonstrating that Augustine had no political theory at all, merely touches upon Augustinisme politique, noting that its propagandists "cannot be accused of a wholesale fabrication." ${ }^{23}$ Although J. van Oort's exploration of Augustine's sources (2013; first published in 1991) is in line with Arquillière, stating that "medieval life was modelled to a great extent after the City of God, but this occurred through a radical metamorphosis," it draws attention to the fact that "no more attention will be devoted to this remarkable historical development," ${ }^{24}$ Neither the British historian D. A. Bullough, who worked on Alcuin and Carolingian history, ${ }^{25}$ nor the German historian and philosopher K. Flasch, specialist on Augustine, ${ }^{26}$ provided anything more than outlines of Augustine's influence on Carolingian thought. Likewise, J. L. Nelson did not do more than hint at Augustine in her research on rituals of inauguration. ${ }^{27}$

The two scholars Alcuin and Hincmar were pre-eminent advisers to the rulers of the first and third generation: Charlemagne and Charles the Bald. They were the most prolific advisers, enjoying significant influence with their respective kings, and both made use of Augustine's ideas directly and for their own distinct purposes. They differ substantially in their style of advice and understanding of ecclesiastical and secular power, so that a comparison of their use of Augustine will shed light on the differences between Charlemagne's reign and the more conflict-ridden reign of his grandson.

The conditions under Charlemagne and Charles the Bald were not the same. ${ }^{28}$ Charlemagne, who expanded the Frankish territory to the North, South and East, faced the challenges of Christianising different conquered peoples and consolidating the Christian faith in these regions by (re-)founding 'churches', dioceses and ecclesiastical provinces (on the basis of the late Roman order) ${ }^{29}$ 
Charlemagne was effective in his military campaigns and cultural reform, ${ }^{30}$ and it was an advantage for him that he could govern Francia without any co-rulers for 42 years. ${ }^{31}$ He had no rivals in his family - his younger brother Carloman I died in $771 .{ }^{32}$ There was time for Charlemagne to establish himself as a powerful sole ruler before acquiring the imperial title. In the generation of Charles the Bald, by contrast, there were intense rivalries. ${ }^{33}$ Rival Carolingians strove to win royal resources, and, throughout his reign, Charles the Bald coexisted with brothers and nephews in separate territories. ${ }^{34}$ He reigned for thirty-seven years and was emperor only in the last two years of his reign. Charles the Bald was in a much less secure political position. ${ }^{35}$ Like Charlemagne, he did not have the institutional means fully to exploit the resources within his realm; unlike Charlemagne, he was no longer able to perform as many plundering raids in order to satisfy the nobility who formed the army..$^{36}$ Instead, Charles the Bald used the strategy of exploiting the 'church's' wealth in a manner previous Carolingian rulers had never tried. ${ }^{37}$ After Charlemagne, the relationship between the 'church' and the 'state' was renegotiated and underwent change. It is the aim of this book to shed light on how Alcuin's and Hincmar's style of political advice, be it complimentary or critical, was shaped by these structural changes, and what Augustine and his De civitate Dei could yield to the advice in each of the circumstances.

\section{Framing the enquiry}

The book is divided into three parts and seven chapters. Three chapters are concerned with Augustine and his De civitate Dei, two chapters each discuss the political advice of Alcuin and Hincmar.

In order to distinguish between Augustinian ${ }^{38}$ and non-Augustinian elements in the Carolingian sources, an introductory treatment of essential questions relating to Augustine, his late work, the De civitate Dei, and the Roman empire of the fourth and early fifth centuries is necessary. I explore the meaning Augustine attributes to worldly rule and politically organised communities, and I analyse how Augustine defines and evaluates temporal 'states' (particularly the Roman 'state') and how he portrays the relationship between rulers and God in the De civitate Dei. This first part lays out the themes and concepts of Augustinian thinking that are relevant to an examination of the Carolingian material. It consists of survey work and forms the basis upon which Carolingian political thought and political ethics can then be scrutinised - ideas that, while echoing Augustine in many respects, were arguably derived from propositions and demands fundamentally different to his own.

The second and third parts of the book concentrate on the two high-flying Carolingian political advisers Alcuin and Hincmar. Two chapters are devoted to each author. In each chapter, selected texts are analysed in light of Augustine's possible influence. The analyses engage with ideas about empire and the moral conduct of political agents. They ask questions relating to Augustine and his De civitate Dei. 
The primary theme in Part II on Alcuin is political thought, with an emphasis on the notions of rulership and the value of ruling power in the context of God's providential plan. The question of the salvific meaning Alcuin attributes to Carolingian rulership, as compared with that which Augustine assigns to the Christian Roman emperors, forms part of the discussion. Alcuin's Epistolae provides the main source material. The decision to focus on the correspondence is based on the proposition that the letters Alcuin wrote to Charlemagne and his descendants, or to his closest friends (e.g. Arn, Bishop of Salzburg, and Angilbert, Abbot of Saint-Riquier), not only reveal the nature of Alcuin's political thinking, but also the manner in which he communicated the thoughts he considered important for the strengthening and legitimating of Carolingian rule to his peers. The epistles show more clearly than any of his treatises the way in which he went about convincing Charlemagne and the surrounding community to implement his political scheme. The procedure for selecting the epistles was as follows: after reading the collection of Alcuin's Epistolae in the Electronic Monumenta Germaniae Historica (eMGH), I selected the letters in which Alcuin expresses his political ideas. These did not merely include letters to the ruler; I looked for any letters containing statements about the ruler's influence on political and religious affairs, legitimating the ruler's authority, or dealing with important events (such as coronations and events involving Pope Leo III). I cross-checked using the word search on the $e M G H$ and entered keywords used by Alcuin in political contexts in order to verify that no significant epistles were overlooked. Finally, I drew on secondary literature to facilitate contextualisation.

The leading theme in Part III on Hincmar is political ethics, exploring Hincmar's Epistolae, his Expositiones ad Carolum Regem and his De regis persona et regio ministerio. While the Epistolae are examined for all kinds of explicit references to Augustine, the analyses of the latter texts are concerned with advice either on how to lead a Christian life according to certain moral principles or on how to rule in consideration of Christian political ethics. The Expositiones ad Carolum Regem consist of three legal opinions composed for the Synod of Pitres in 868. Since they reflect Hincmar's opinion on a legal dispute in which he supports his nephew by defending the 'church' property against Charles the Bald's claim, they are concerned with political morality and ethics. Hincmar's De regis persona et regio ministerio belongs to the tradition of so-called 'mirrors for princes', ${ }^{39}$ medieval treatises for the instruction of Christian rulers. The premise of my analysis is that political ethics were useful for instilling a sense of common mission for the secular power and thus formed an important part of Carolingian political thought. ${ }^{40}$ Hincmar lived under a 'state' that, for its effectiveness, relied heavily on persuading an existing landed elite ${ }^{41}$ that it was worthwhile to participate in a common, empire-wide project. The late Roman empire Augustine knew, and which he was critically analysing in the De civitate Dei, had by contrast a formal and professionalised 'state' apparatus based on tradition. However, Augustine and his Carolingian-era readers shared an important common opinion that secular politics and political success were fundamentally moral issues, which demanded adherence to stringent moral standards. The reasoning was that 
political success was granted by God alone. ${ }^{42}$ The elements of Augustine's moral values that were most often picked out by, and which found most resonance with his ninth-century readers, reveal much about continuities between late antique and Carolingian political thought, as well as about the precise nature of the displacement involved in using Augustine's words in order to speak to a fundamentally different political situation.

The conclusion brings together and contextualises the findings from each part of the research. I compare and contrast the influence Augustine had on Alcuin and Hincmar. Consideration is given to the differences between Augustine's, Alcuin's and Hincmar's ideas of 'church' and 'state' in light of the changed political situation.

\section{A philological-historical approach to the sources}

The method I propose for dealing with the primary sources may be justified on two grounds; one is related to the subject matter of the investigation and is explained by its very nature, the other one is a matter of my personal preference for a particular method of investigation.

The first one may be explained as follows: the study I embark on is not concerned with the political history of the Carolingian era in and of itself, but with the manner in which Augustinian political thought and political ethics took shape in the Carolingian empire. This means that the research should at least to a minimum extent take account of the history of ideas between 400 and 800 and acknowledge the fact that Augustine's ideas had been passed down in written Latin for 350 years before reaching the Carolingians. It seems appropriate, therefore, to choose an approach that is sensitive to the language and the etymology of concepts, in other words, a philological-historical approach. Furthermore, this book is concerned with texts written in an empire that had Christianity as its 'state' religion, and, at the same time, with the early Christian thought of a pre-eminent Church Father. This implies that in all the texts under investigation, Christian doctrine plays an essential role. Since, according to Scriptures, ${ }^{43}$ the "word" ( $\lambda$ ó $\gamma \circ \varsigma$ ) is divine, Christian texts from the beginning placed emphasis on the meaning and origin of words. This is another reason why semantic and etymological aspects should not be ignored. When early medieval commentators read Augustine, they were not simply reading Augustine's words - theirs was a 'thick' reading of the text, imbued with connections to concepts, terms, expressions and figures familiar to them from Biblical, patristic and exegetical writings. This makes an intertextual method indispensable to any attempt to understand how the Carolingians interpreted Augustine's words, and what they thought were his main concerns.

Secondly, I take personal inspiration for part of the method from the synthetichistorical analysis undertaken by E. Auerbach in Mimesis (1953; first published in German in 1946) and Literatursprache und Publikum in der Lateinischen Spätantike und im Mittelalter (1965; first published in German in 1958). ${ }^{44}$ Auerbach was a philologist interested in the history of Western European ideas and contributed significantly to the investigation of how Christianity influenced literary word formation in the Middle Ages. 


\section{Introduction}

As far as the methodology chosen in this research is concerned, I approach the sources in two ways; I look for explicit evidence and for implicit evidence of Augustine's influence on Alcuin and Hincmar in separate chapters. To search the sources and locate these direct and indirect references to Augustine, I use the eMGH and the Patrologia Latina database.

The procedure for the first approach is to find various kinds of explicit references to Augustine. These include the mentioning of his name, citation and quotation. The following questions are asked with regard to the direct evidence thus located: how often is Augustine named, cited or quoted? Where in a text (beginning/middle/end)? Concerning what topic? For what purpose? Which of his works does the author cite? From which works does he quote? How precise are his citations and quotations? How does Alcuin or Hincmar incorporate Augustine into his reasoning by direct quotation? The answers should reveal to what extent the author used Augustine's thought directly and which aspects of his thinking struck him particularly. The aim of this method is to discern whether there is a qualitative or quantitative difference in these Carolingian sources between explicit references to Augustine or his works and explicit references to other Church Fathers or patristic sources. I examine direct references to see what the Augustine corpus looked like to the Carolingians (i.e. which of his works were available to them). I expect that the two Carolingian authors draw on Augustine directly for the purposes of instruction and solving dogmatic questions. This means that citations and quotations from works such as the De trinitate, De doctrina christiana, De catechizandis rudibus, Enchiridion and Sermo Ioannis Evangelii should occur often.

The second approach explores the implicit evidence of Augustine's influence at two different levels: the level of content and the formal level of the Carolingian texts. I examine the implicit evidence in addition to the explicit evidence in order to see a wider range of Augustine's influence in Alcuin's and Hincmar's texts.

At the level of the content, I look for correlations and differences between Augustinian and Carolingian political ideas and political ethics. The content analysis sheds light on which features of Augustinian thought (as manifested in the De civitate Dei) the two Carolingian authors embraced most.

The formal analysis of the Carolingian texts is concerned with indirect references to Augustine in the author's language. The primary source of inspiration for this method is the type of historical philology developed by Auerbach, which strives for a synthesis. The technique Auerbach expounds in his Literatursprache und Publikum in der Lateinischen Spätantike und im Mittelalter seeks to find linguistic elements in the sources that are worth investigating because they help explain coherences between texts. ${ }^{45}$ It involves linguistic comparison (in terms of terminology, grammar, rhetoric or style) between passages relevant to the subject of the research. Auerbach proposes this method as an alternative modus operandi in cases where existing modern categories fail to help researchers to devise a concrete plan for approaching a particular problem they have located in a certain historical context. ${ }^{46}$ I believe that Auerbach's approach is fruitful for two reasons: firstly, it compels researchers to establish early in their work what can be identified as characteristic within the source material. Secondly, it does not impose 
external theoretical frameworks on the text but looks for what is characteristic in the material itself.

My own procedure is to collect passages relevant to the subject matter and examine them for recurrent concepts, terms, expressions and figures. I interpret these elements in relation to their various contexts, which enables me to define them. What I derive from this method is to come closer to understanding the meaning of the text in the historical context under investigation. The formal analysis serves as a complement to the content analysis. It presents a particular challenge since it involves the process of evaluating the meaning of these elements as understood by Augustine and the two Carolingian authors, as well as that of assessing the relation between Augustinian thought and Carolingian thought under Charlemagne and Charles the Bald.

What I do with the Carolingian sources is to focus on concepts that I can show, in Part I of the book, to be characteristic of Augustine and prominent in the De civitate Dei. Hence, the point of departure is to define the original Augustinian meaning of the selected linguistic elements (as established in part by modern scholarship ${ }^{47}$ ). The process of defining what Augustine seems to have meant requires a critical examination of Augustine's work De civitate Dei, undertaken in Part I. Subsequently, the meaning these elements acquire in the Carolingian texts can be determined. The concepts, terms, expressions and figures include: the political terms civitas Dei, populus Christianus, imperium Christianum, regna terrarum, imperare/imperium and gentes/gentilitas; the expressions dilatare, subicere, subdere and subiugare/iugum, as well as the concepts of dispensatio, pax, iustus/iustitia, felix/felicitas, beatus/beatitudo, misericors/misericordia and humilis/humilitas. I also discuss the representation of the following figures in relation to Charlemagne and Charles the Bald: the Old Testament kings David and Solomon and the Christian Roman emperors Constantine I and Theodosius I. The selection is based on a close study of Augustine's De civitate Dei and the texts of the two Carolingian authors. It involved reading for meaning (with regard to political thought and ethics), for terminology, for expressions and phrases, as well as for clusters of terms. I discuss concepts that I found often in contexts where Augustine, Alcuin and Hincmar reflect on the worldly 'state', secular power and political ethics. The relevance of these elements to Augustine and the Carolingians ${ }^{48}$ has partly been confirmed by other scholars. The questions asked are the following: are there any parallels to Augustine in linguistic terms? If the Carolingian author avails himself of Augustinian elements, how does his meaning correspond to or differ from that of the original Augustine? Are the Augustinian language and terminology the author uses given a new political meaning? If yes, what is its nature? By examining the form and the content of the texts, the influence of Augustinian ideas emerges as more pervasive in Alcuin's and Hincmar's material, and the reader sees the sources as political discourses defined by content and language. ${ }^{49}$ It is possible to discern whether the Carolingians' political statements contain Augustinian elements and whether these statements are imitating Augustine's language. It can be explored whether Alcuin and Hincmar were using this language in Augustine's sense or with a shift in meaning, and whether they 


\section{Introduction}

were using it to make a political statement conformed to Augustinian thought or not. The answers contribute to solving the research questions of whether the Carolingian texts were influenced by Augustine and how Augustinian elements were understood, taken on and modified to serve the Carolingian imperial dynasty.

Q. Skinner, in his reflections on the relevance of language in methodology and the history of political thought, echoes what Auerbach expressed and formulated half a century ago: the importance of the contextualisation of texts for understanding their original purpose and function. ${ }^{50}$ Skinner draws on J. L. Austin and J. R. Searle ${ }^{51}$ stating that he had recourse to the theory of speech acts in order to appeal for "a more historically-minded approach to the history of ideas." 52 He highlights two dimensions of language: the dimension of meaning and the dimension of linguistic action. ${ }^{53}$ Skinner's point is that any author (even more so political writers and rhetoricians), in choosing certain words, pursues a certain purpose and, hence, performs an action. ${ }^{54}$ Skinner, likewise, emphasises the relationship between language and power, and refers to the fact that, particularly in political discourse, the power of words is exploited in order to shape the social world and engage in exercises of social control. ${ }^{55}$ More generally, Skinner calls attention to the importance of considering aspects such as performativity (the process by which semiotic expression in language produces results or real consequences in extrasemiotic reality) and intertextuality (how a text's meaning is shaped by another text) when approaching sources and trying to establish the original meaning and motive of texts under investigation. ${ }^{56}$ By dedicating the first part to Augustinian thought in the De civitate Dei and two complementary parts to Augustine's influence on Carolingian political thought and political ethics, I am hoping to let the texts speak to one another. The second and third parts initially focus on epistles as a genre and discuss explicit references to Augustine. I start out with a sample letter to each ruler (i.e. Charlemagne and Charles the Bald). In each case, I explore how and to what end Augustine is formally represented and integrated into the author's reasoning, while references are made to other letters (in order to establish correspondences in structure). Only afterwards will a content analysis and formal analysis of further epistles and other works follow.

Having read Alcuin's and Hincmar's texts and explored what is particular about the direct and indirect references to Augustine, I eventually ask why some Augustinian ideas are understood differently by these authors. Having started out from Augustine in a late Roman context and given a close reading of Alcuin and Hincmar, I end by expanding the focus again in an attempt to contextualise the Augustinianism Alcuin and Hincmar used as a body of ideas relevant to the Carolingian condition.

\section{'State-church' relations in late antiquity and the Early Middle Ages}

In the early fifth century, Augustine envisioned a certain relationship between the 'state' and the 'church that can be derived from later writings including the De civitate Dei: $:{ }^{57}$ Augustine recognised the imperfect worldly 'state' as an instrument 
of power for missionary purposes ${ }^{58}$ and saw a functional relationship between 'state' and 'church'. ${ }^{59}$ In his correspondence (e.g. epist. 48 ad Vincentium from 408), Augustine approved of laws and government regulations for religious affairs, particularly concerning pagans and schismatics (e.g. Donatists) or when they supported the 'church' ${ }^{60}$ Several passages defending the Christian religion in the De civitate Dei provide evidence that Augustine approved of the imperial repression of pagan cults. ${ }^{61}$ However, in purely abstract terms, Augustine regarded the 'state' as a worldly system of power separate from the 'church'. ${ }^{62}$ 'State' and 'church' referred to two distinct spheres. The 'church's' superior role was not to be understood in a worldly sense. ${ }^{63}$ The 'church' has an immortal soul and an eternal mission, which the 'state' evidently lacks. ${ }^{64}$ In this sense, Augustine's 'church' cannot be compared to any earthly systems of rule due to its timelessness, and it lacks a clear hierarchical structure. ${ }^{65}$ Flasch and M. De Jong note that Augustine's 'church' is a community, rather than a hierarchically structured body. ${ }^{66}$ The Carolingian 'church' too aspired to constant expansion, which was achieved by secular means. ${ }^{67}$ Since Late Antiquity the 'church' had become more powerful and wealthy ${ }^{68}$ Another difference lay in the scope of the later 'church' councils: the late Roman councils had been more wide-ranging. ${ }^{69}$ The Carolingian 'church' councils, however, were less interlinked with other regions and merely involved bishops from the same kingdom. ${ }^{70}$

It is clear that the 'church' - as it features in this book - is a concept that was subject to change over the period of time covered in this investigation (i.e. roughly from the fourth to the ninth century). It is not possible to provide a single and firm definition of 'church' that would cater to the broad spectrum of meanings the concept implies. I decided to use 'church', enclosed in single quotation marks, consistently in this research. 'Church' may refer to a general Christian spiritual power or to a distinct Christian institution with a distinct sphere of action. What 'church' always presupposes is a contrast to the 'state'.

The 'state' itself can take many forms, and in a pre-modern context it would be difficult to imagine two 'states' more dissimilar than the late Roman empire and the Carolingian empire. The Carolingian 'state' did not have a standing army, or a full-time bureaucracy, or standard forms of delegation of political powers, or such a complex system of taxation as had made the late Roman empire so powerful an entity. Carolingian rulers had a different hand to play with, which made them by definition dependent on consensus. ${ }^{71}$ One could claim that in terms of structures and forms of government, the Carolingian 'state' had a shape closer to that of Augustine's 'church' than to his 'state', and that it operated not unlike a 'church' council. Carolingian rulers seem to have consciously made this connection. ${ }^{72}$

This minimalist reading of the Carolingian 'state' apparatus is a recent historiographical phenomenon. The traditional European scholarship on Carolingian history from the first half of the twentieth century was led by French and German scholars who examined Carolingian politics and society from an angle that focused on formal, institutional and constitutional elements. Their reading of Carolingian politics was idealised. French/Belgian historians until Ganshof put forward a maximalist view of Carolingian administrative structures; German scholars also 
studied representations of rulership and power as descriptive rather than aspirational. While they focused more on political symbolism, they saw the political community as a near theocracy. ${ }^{73}$ This perception was current throughout the 1950 s and 1960s and is visible in the works of W. Ullmann and P. E. Schramm. ${ }^{74}$

Historians' treatment of the Carolingian 'state' has shifted since the 1970s. The historiographical debate in Britain has revolved around the research of three prominent medievalists. The work of R. McKitterick is based on palaeographical and manuscript studies as a foundation for the study of Carolingian politics, culture and society. This is apparent in her contributions on Carolingian law. ${ }^{75}$ McKitterick attempts to establish how different pieces of written law were used by the Carolingians and to illuminate their implementation of legislation by looking at particular manuscripts in relation to a family of manuscripts. Formal aspects of the manuscript are scrutinised. The method provides insight into the manner in which Carolingian law books were put together and used. However, a description of how this written law was brought outside the court and practised is missing. Since every surviving manuscript can be seen as a success story, using these as a starting point leads her to adopt an optimistic stance on the Carolingian 'state' as a smooth-running operation, which is reminiscent of the more traditional, German approach. ${ }^{76}$ P. Wormald also published work on law. ${ }^{77}$ However, he saw Carolingian law-making more in an ideological context. Wormald examined law in connection with rituals and symbolism, which he tried to set within a European frame of reference. In Wormald's view, written law was a product of aspiration. His argument clashes with that of McKitterick, who says that for Carolingian rulers the main goal of law making must have been the capacity to judge every man in the kingdom "according to the law peculiar to the particular national group to which he belonged." 78 Nelson's research stands out by posing a different set of questions. She attempts to shed light on the place of politics, law and society in a wider context. Nelson is concerned with the question of how, in the course of Carolingian rule, written documents exposed and portrayed the dynamics of politics, law and society. Her findings on political thought and community owe much more to anthropology. In her work, she emphasises the fact that, in order to conduct politics in a successful manner, consensus had to be created. ${ }^{79}$

The shift in the historians' interpretation of the concept of 'state' is largely the result of recent emphasis on interdisciplinarity. Anthropological findings concerning small- or no-'state' societies have influenced historians' methods. This more recent scholarship argues that even institutionally weak 'states' can be called 'states'. Accordingly, more dynamic questions, such as how politics happened as a process, are called for on the part of the researcher. ${ }^{80}$ Political thought as studied in the old constitutional style, i.e. rather detached from Carolingian society as a political community, has been left behind by this new historical scholarship. Augustine has not yet found a place in the more recent picture of Carolingian political relations. It is the contribution of this book to relate Augustine to the more recent research on Carolingian political ideas and to see what he had to offer readers and political thinkers of that period, now that the political context they were working in has been so radically re-evaluated. 
All the terminology for different types of politically organised communities that I examine in the primary sources is in Latin. The key terms I discuss in this book are: regnum, imperium, res publica, civitas and societas. Markus asserts that "the terms in which Augustine came to formulate his views on politically organised society" are "roughly what we should nowadays call the 'state'." For example, he translates res publica as "state." 82 J. Dunbabin, by contrast, says that regnum, res publica and civitas "could, but need not, denote that combination of a precise territorial area with a form of political organisation which 'state' implies for us." ${ }^{83}$ Another scholar, R. Martin, reads the famous political passage on regna in Chapter 4 of Book IV of the De civitate Dei ${ }^{84}$ as relating to the "imperial state" in general, which he sees as representative of the civitas terrena. ${ }^{85}$ Although regnum more specifically denotes "kingdom" and imperium denotes "empire," I follow Martin's view and define "state" as a suitable, broader translation of regnum and imperium. For the above reasons, I consider it justified to use the English word 'state', enclosed in single quotation marks, for the Latin terms that designate different types of politically organised communities. "Society" and "association" are relatively appropriate renderings of societas and are therefore used in this way. Wherever I examine a particular Latin term comprehensively, my translation is based on a more detailed analysis.

\section{Notes}

1 The use of modern concepts and abstractions such as 'state' in scholarship concerning the Early Middle Ages is contentious. Pohl 2002, pp. 281-285; Pohl 2006, pp. 9-38. A more detailed treatment of my use of the concept of 'state' can be found under 'StateChurch'Relations in Late Antiquity and the Early Middle Ages.

2 A more detailed treatment of my use of the concept of 'church' can be found under 'State-Church' Relations in Late Antiquity and the Early Middle Ages.

3 The ambiguity of the terms 'reform' and 'renaissance' with reference to cultural renewals in the early Middle Ages has been the subject of debate over recent decades. See the seminal work Treadgold 1984.

4 See Dempf 1973; Arquillière 1934; Ganshof 1949; Patzelt/Vogel 1965; Steinen 1967.

5 V.Kar. 24, p. 29.

6 For the Carolingian dynasty in a broader historical and geographical context, see Fouracre 2005; McKitterick 1995; Reuter 2000; Wickham 2005; 2016.

7 See Arquillière 1934.

8 In line with The Cambridge History of Greek and Roman Political Thought, I distinguish between "political thought" and "political theory" in my research. Both categories involve people who do the thinking. "Political thought," the broader category, is used with reference to general, unsystematic reflection on things political. "Political theory" is used for a framework of thought that "... represents direct, systematic reflection on things political ..." Rowe 2010, pp. 1-6.

9 An introduction to comparing kings and kingship in the ancient and medieval worlds is Mitchell and Melville 2013, pp. 1-22.

10 Arquillière 1934, pp. 151f.

11 Baynes 1936.

12 Ibid., pp. 3, 15-16.

13 Dempf 1973, p. 134. 


\section{Introduction}

14 Ganshof 1949, p. 9. Ganshof and Braunfels et al. 1965-1968 are general studies, now dated, on the meaning and reception of Charlemagne's life, work and elevation to the imperial throne.

15 Patzelt/Vogel 1965, p. 17.

16 Steinen 1967, p. 17.

17 Ganshof 1949, pp. $26 f$.

18 According to Wallace-Hadrill, the Carolingian 'state' is a community united by unanimitas and defined by a mutual interest in Christian peace. The consensus among its members, Wallace-Hadrill argues, is evocative of Augustine's idea of the 'state'. Wallace-Hadrill 1975, pp. 188-189. The Carolingian 'state' is to be understood in the sense of Augustinisme politique: "... Natural Law has become absorbed in supranatural justice, the Law of the State in that of the Church." Ibid., p. 192.

19 Dvornik 1966, p. 849. A discussion of Dvornik's support for Arquillière's Augustinisme politique can be found under Iustitia and Pax in Concepts of Augustinian Political Thought, the third chapter of Part I.

20 Anton's work is a general study enquiring into the Carolingian ethos of rulership and 'mirrors for princes'. His analysis of ninth-century mirrors is based on an exploration of the sources (e.g. Augustine, Gregory the Great, Isidore, Pseudo-Cyprian) used by the Carolingian authors. Anton 1968, pp. 47-74. An examination of different sub-genres of ninth-century 'mirrors for princes' follows an investigation of Alcuin's eighth-century discourse of admonition. Ibid., chapters II and III. Anton shows that Hincmar's work largely follows in the tradition of the "konziliare Fürstenspiegel," which developed a doctrine of the person and the office on the basis of Augustine and Gelasius. Ibid., pp. 225, 286ff., 290-293, 352-356. In Hincmar's De regis persona et regio ministerio, Anton sees a culmination of Arquillière's Augustinisme politique. Ibid., pp. 230f.

21 Wilks 1967. However, Wilks is unsuccessful since his argument compels him to assume that Augustine conceived a full realisation of iustitia in a Christian setting. Ibid., pp. 489-493, 499.

22 Markus 1970, p. 168.

23 Boler 1978, pp. 83, 87, 90. Boler bases his argument on Markus.

24 Oort van 2013, p. 92.

25 See Bullough 1991; 1999; 2003; 2004.

26 See Flasch 2003; 2008.

27 Nelson 1994, p. 56; see Nelson 1996b.

28 See Story 2005; McKitterick 2008; Nelson 1992.

29 For a contextualisation of Charlemagne's reign, see Bachrach 1998, pp. 214-231. On Charlemagne's reform of the Frankish 'church', see De Jong 2005, pp. 103-135; McKitterick 1977, pp. 1-44 on the legislation for reform, pp. 45-79 on the episcopal statutes; Christie 2005, pp. 167-180 on the restoration of the ecclesiastical heritage of Rome.

30 The expansion of learning, the dissemination of the Christian religion and Biblical and other texts are covered in McKitterick 2005, pp. 151-166.

31 A recent biographical account of Charlemagne is Hägermann 2006. On the representation of Charlemagne in Carolingian texts, see also Nelson 2005, pp. 22-37.

32 Ibid., p. 28.

33 The best full account of Charles the Bald is Nelson 1992. See in particular pp. 71-74.

34 On the rivalries during the years $840-843$, see ibid., pp. 105-131; for the years 850 858 , see ibid., pp. 160-189.

35 See the treatment by Wallace-Hadrill 1971, pp. 125-128. The workings of politics at the centre and the participation of the aristocracy, whose power was based on local landlordship, are illustrated in Nelson 1992, pp. 41-65.

36 Wickham 2016, pp. 65-68. On the economic situation, see Nelson 1992, pp. $21 \mathrm{ff}$.

37 Ibid., pp. 61-66; Wallace-Hadrill 1971, pp. 126-127.

38 By 'Augustinian', I refer to the thought that is manifested in Augustine's later work - in particular the De civitate Dei. 
39 On the genre, see Stone 2012, pp. 42-46.

40 Nelson 1986, pp. 170-171; Nelson 1994, pp. 66-69; Nelson 1996a, p. 97; Nelson 1996b, pp. 115-120.

41 The Carolingian 'elite' including the distinction between laymen and ecclesiastics is discussed in Sot 2009, pp. 341-361.

42 Nelson 1994, p. 58.

43 See the opening of the Gospel of John. Jn 1:1.

44 Auerbach 1946; 1958.

45 Auerbach 1958, pp. 18-21.

46 Ibid., pp. 19-20.

47 My linguistic argument is based on findings from Bons et al. 2015; AL vols. 1-4, Doppelfasz. 5/6 1986-2017; Pollmann and Otten 2013; TLL Online 1900-. Furthermore, it draws on the work of Arquillière; Bullough; Ganshof; R. McKitterick; and Nelson.

48 For imperium and gentes, see Bullough 1999; McKitterick 2004. For imperium Christianum and populus Christianus, see Ganshof 1949. For iustitia and pax, which are elements of the doctrine of Augustinisme politique, see Arquillière 1934.

49 That my method is applicable to the Carolingian context is evident, inter alia, in Stone 2012, p. $20 \mathrm{f}$.

50 Skinner 2013, pp. 1-7.

51 See Austin 1976.

52 Skinner 2013, pp. $2 \mathrm{f}$.

53 Ibid.

54 Ibid., pp. 2-5.

55 Ibid., pp. 5-7.

56 Ibid., p. vii.

57 Flasch 2003, pp. 391, 393.

58 On Augustine's "infamous theological justification of force," see Campenhausen von 1964, pp. 238-240.

59 Flasch 2003, pp. 164, 391-393. This is confirmed by R. Dodaro, who writes that, with the reign of Emperor Constantine I "... and continuing into the early Middle Ages, the governing structures of the Christian church and of the Roman Empire developed closer relationships, even while retaining their separate identities.” Dodaro 1999, p. 176. See also Markus 1988, p. 86; Baynes 1936, pp. 14-15.

60 Dvornik 1966, pp. 842-843; Dodaro 1999, pp. 180-181. On Augustine and religious coercion under Theodosius I and his successors, see Markus 1988, pp. 113-115.

61 At one point Augustine says that people who object to being forced to convert to Christianity are unreasonable and ungrateful. Civ. II 28 , p. 94 . He also mocks the pagans by declaring that they would be happier in life if criticism of the Christian religion were prohibited by law - except that they would of course fail to recognise their good fortune. Civ. V 26, pp. 241-242. Such statements reveal that Augustine tackled the difficulty of reducing the strongly divergent concepts of love of neighbour and affirmation of force to a common denominator by dressing force up as necessary rigour for the benefit of the people. Flasch 2003, pp. 164ff.

62 Ibid., p. 391; Dempf 1973, p. 134.

63 Flasch 2003, p. 391; Baynes 1936, p. 15.

64 Flasch 2003, p. 392. Markus, for example, speaks of “... an 'otherworldly' Church ...”" when referring to the 'church' in this abstract sense. Markus 1970, p. 133.

65 Flasch 2003, pp. 386-388.

66 Ibid., p. 388; De Jong 2009, p. 242.

67 This is well reflected by the Saxon War, which lasted from 772 until 804 and was, according to Einhard, Charlemagne's longest and most strenuous battle. V.Kar. 7, p. 9; Büttner 1967, p. 467; Fleckenstein 1990, p. 32. In the war between 791 and 803/811 against the Avars, who continuously invaded Upper Italy and Bavaria, Charlemagne conducted forced baptisms between 795 and 796. Fleckenstein 1990, pp. 48-50; Büttner 1967, pp. 476, 479; V. Kar. 13, pp. 15-16. 


\section{Introduction}

68 For a contextualisation and intercultural comparison of religious authority and the 'state' in the Middle Ages, see Black 2014, pp. 539-550.

69 Morrison 1985, p. 14. On the African 'church' synods during Augustine's episcopate, see Dodaro 1999, p. 180. Episcopal councils at Carthage mediated the African 'church's' relations with imperial authorities. The councils enabled the African bishops to negotiate directly with the imperial court at Ravenna and to take a united stance on legislation favourable to the African 'church'. Ibid., p. 180.

70 Carolingian rulers convoked 'church' councils. As in Augustine's day, the structures of the Carolingian imperial 'church' readily allowed merging with secular structures. Morrison 1985, pp. 3-52; see also Cameron 1991. It should be noted, however, that bishops in particular assumed these secular functions. See Rapp 2005.

71 See Une gestion décentralisée de la 'potestas' in Le Jan 1995, pp. 99-122. See also Nelson 1996b.

72 For instance, 'church' councils held in the Carolingian empire could very well be integrated in legislation. The Admonitio generalis, for example, drew more material from canon law than from any other source. The decisions of the Council of Frankfurt (794), whose subjects of negotiation were drawn up in fifty-six chapters that discuss theological, political and legal matters, were summarised in a capitulary.

73 For a recent German intercultural study of theocracy's social and political impacts, see the edition Trampedach and Pečar 2013.

74 See Ullmann 1969; 1974; Schramm 1983. The publications discuss the characteristics of the Carolingian reforms and political thought more generally. However, they are now obsolete.

75 McKitterick 1980, pp. 13-27.

76 E.g. Beumann 1967; McKitterick 2004, p. 114.

77 See Wormald 1977; 1999.

78 McKitterick 1980, p. 14.

79 See in particular Nelson 1986; 1994; 1996a, b.

80 On the perceptions of the 'state' in recent historical scholarship see the debate between R. Davies and S. Reynolds. Davies 2003; Reynolds 2003.

81 Markus 1970, p. 209.

82 Ibid., pp. 65-66.

83 Dunbabin 1988, p. 479.

84 Civ. IV 4, pp. 112-113.

85 Martin 1972, pp. 195, 204-206.

\section{Bibliography}

\section{Primary sources}

Einhardus: Vita Karoli Magni. Post G. H. Pertz Recensuit G. Waitz. Editio sexta. Oswald Holder-Egger (ed.) (MGH SS rer. Germ. 25). Hannover, 1911.

Hipponensis, Augustinus Sancti Aurelii Augustini episcopi De civitate Dei libri XXll 2 vols. Bernhard Dombart et Alfons Kalb (recogn.). (5th ed.), Stuttgart, 1993.

\section{Secondary sources}

Anton, Hans Hubert: Fürstenspiegel und Herrscherethos in der Karolingerzeit. Bonn, 1968.

Arquillière, H.-X.: L'Augustinisme politique: Essai sur la formation des théories politiques du Moyen-Âge. Paris, 1934. 
Auerbach, Erich: Mimesis: Dargestellte Wirklichkeit in der abendländischen Literatur. Bern, 1946 (first published in English in 1953).

Auerbach, Erich: Literatursprache und Publikum in der lateinischen Spätantike und im Mittelalter. Bern, 1958 (first Published in English in 1965).

Austin, John Langshaw: How to Do Things with Words. (2nd ed. by James Urmson and Marina Sbisà) London, 1976.

Bachrach, Bernard S.: Pirenne and Charlemagne, in: Alexander Callander Murray (ed.): After Rome's Fall: Narrators and Sources of Early Medieval History. Toronto, 1998, 214-231.

Baynes, Norman Hepburn: The Political Ideas of St. Augustine's. De Civitate Dei. Historical Association Pamphlet 104, 1936, 3-18.

Beumann, Helmut (ed.): Persönlichkeit und Geschichte, Karl der Grosse: Lebenswerk und Nachleben. Düsseldorf, 1967.

Black, Antony: Religious Authority and the State, in: Robert Pasnau and Christina van Dyke (eds.): The Cambridge History of Medieval Philosophy 2 vols. (2nd revised ed.) Cambridge, 2014, 539-550.

Boler, John: Augustine and Political Theory. Mediaevalia: A Journal of Medival Studies 4, 1978, 83-97.

Bons, Eberhard et al. (eds.): Biblical Lexicology: Hebrew and Greek: Semantics, Exegesis, Translation. Berlin, 2015.

Braunfels, Wolfgang et al. (ed.): Karl der Grosse: Lebenswerk und Nachleben 4 vols. Düsseldorf, 1965-1968.

Bullough, Donald A.: Carolingian Renewal: Sources and Heritage. Manchester and New York, 1991.

Bullough, Donald A.: Die Kaiseridee zwischen Antike und Mittelalter, in: Christoph Stiegemann and Matthias Wemhoff (eds.): Kunst und Kultur der Karolingerzeit: Karl der Grosse und Papst Leo III. in Paderborn: Beiträge zum Katalog der Ausstellung, Paderborn 1999. Mainz, 1999, 36-46.

Bullough, Donald A.: Was There a Carolingian Anti-War Movement? Early Medieval Europe 12(4), 2003, 365-376.

Bullough, Donald A.: Alcuin: Achievement and Reputation: Being Part of the Ford Lectures Delivered in Oxford in Hilary Term 1980. Leiden, 2004.

Büttner, Heinrich: Mission und Kirchenorganisation des Frankenreiches bis zum Tode Karls des Grossen, in: Helmut Beumann (ed.): Persönlichkeit und Geschichte, Karl der Grosse: Lebenswerk und Nachleben Vol. 1. (3rd ed.). Düsseldorf 1967, 454-487.

Cameron, Averil: Christianity and the Rhetoric of Empire: The Development of Christian Discourse. Berkeley and Los Angeles California, 1991.

Campenhausen von, Hans: The Fathers of the Latin Church. Transl. by Manfred Hoffmann. London, 1964.

Davies, Rees: The Medieval State: The Tyranny of a Concept? Journal of Historical Sociology 16(2), 2003, 280-300.

De Jong, Mayke: Charlemagne's Church, in: Joanna Story (ed.): Charlemagne: Empire and Society. Manchester, 2005, 103-135.

De Jong, Mayke: The State of the Church: Ecclesia and Early Medieval State Formation, in: Walter Pohl and Veronika Wieser (eds.): Der Frühmittelalterliche Staat-Europäische Perspektiven. Budapest, 2009, 241-254.

Dempf, Alois: Sacrum imperium: Geschichts- und Staatsphilosophie des Mittelalters und der politischen Renaissance. (4th ed.; 1st ed.. 1929). Darmstadt, 1973. 


\section{Introduction}

Dodaro, Robert: Church and State, in: Allan Fitzgerald (ed.): Augustine Through the Ages: An Encyclopedia. Grand Rapids, Michigan, 1999, 176-184.

Dunbabin, Jean: Government, in: James Henderson Burns (ed.): The Cambridge History of Medieval Political Thought c. 350-c. 1450. Cambridge, 1988, 477-519.

Dvornik, François: Early Christian and Byzantine Political Philosophy: Origins and Background 2 vols. Washington, D. C., 1966.

Flasch, Kurt: Augustin: Einführung in sein Denken. (3rd supplemented ed.). Stuttgart, 2003.

Flasch, Kurt: Kampfplätze der Philosophie: Grosse Kontroversen von Augustin bis Voltaire. Frankfurt am Main, 2008.

Fleckenstein, Josef: Karl der Grosse. (3rd ed.). Göttingen and Zürich, 1990.

Fouracre, Paul (ed.): The New Cambridge Medieval History vol. 1, c. 500-c. 700. Cambridge, 2005.

Ganshof, François Louis: The Imperial Coronation of Charlemagne: Theories and Facts. Glasgow, 1949.

Hägermann, Dieter: Karl der Grosse: Herrscher des Abendlandes: Biographie. (3rd ed.). Berlin, 2006.

Le Jan, Régine: Famille et pouvoir dans le monde franc (VIIe - Xe siècle): Essai d'anthropologie sociale. Paris, 1995.

Markus, Robert Austin: Saeculum: History and Society in the Theology of St Augustine. Cambridge, 1970.

Markus, Robert Austin: The Latin Fathers, in: James Henderson Burns (ed.): The Cambridge History of Medieval Political Thought c. 350-c. 1450. Cambridge, 1988, 92-122.

Martin, Rex: The Two Cities in Augustine's Political Philosophy. Journal of the History of Ideas 33, 1972, 195-216.

McKitterick, Rosamond: The Frankish Church and the Carolingian Reforms, 789-895. London, 1977.

McKitterick, Rosamond: Some Carolingian Law-Books and Their Function, in: Brian Tierney and Peter Linehan (eds.): Authority and Power. Cambridge, 1980, 13-27.

McKitterick, Rosamond (ed.): The New Cambridge Medieval History vol. 2, c. 700-c. 900. Cambridge, 1995.

McKitterick, Rosamond: History and Memory in the Carolingian World. Cambridge, 2004.

McKitterick, Rosamond: The Carolingian Renaissance of Culture and Learning, in: Joanna Story (ed.): Charlemagne: Empire and Society. Manchester, 2005, 151-166.

McKitterick, Rosamond: Charlemagne: The Formation of a European Identity. Cambridge, 2008.

Mitchell, Lynette and Melville, Charles (eds.): Every Inch a King: Comparative Studies on Kings and Kingship in the Ancient and Medieval Worlds. Leiden, 2013.

Morrison, Karl Frederick: Holiness and Politics in Early Medieval Thought. London, 1985.

Nelson, Janet Laughland: Politics and Ritual in Early Medieval Europe. London, 1986.

Nelson, Janet Laughland: Charles the Bald. London and New York, 1992.

Nelson, Janet Laughland: Kingship and Empire in the Carolingian World, in: Rosamond McKitterick (ed.): Carolingian Culture: Emulation and Innovation. Cambridge, 1994, 52-87.

Nelson, Janet Laughland: Translating Images of Authority: The Christian Roman Emperors in the Carolingian World, in: Janet Laughland Nelson (ed.): The Frankish World, 750 900. London and Rio Grande, 1996a, 89-98. 
Nelson, Janet Laughland: The Lord's Anointed and the People's Choice: Carolingian Royal Ritual, in: Janet Laughland Nelson (ed.): The Frankish World, 750-900. London and Rio Grande, 1996b, 99-131.

Nelson, Janet Laughland: Charlemagne the Man, in: Joanna Story (ed.): Charlemagne: Empire and Society. Manchester, 2005, 22-37.

Oort van, Johannes: Jerusalem and Babylon: A Study into Augustine's City of God and the Sources of His Doctrine of the Two Cities. (Repr. of the 1st ed. 1991). Leiden, 2013.

Patzelt, Erna/Vogel, Cyrille: Die Karolingische Renaissance./La réforme culturelle sous Pépin le Bref et sous Charlemagne. (2nd ed.). Graz, 1965.

Pohl, Walter: The Politics of Change: Reflections on the Transformation of the Roman World, in: Walter Pohl et al. (eds.): Integration und Herrschaft: Ethnische Identitäten und soziale Organisation im Frühmittelalter. Wien, 2002, 275-288.

Pohl, Walter: Staat und Herrschaft im Frühmittelalter: Überlegungen zum Forschungsstand, in: Stuart Airlie et al. (eds.): Staat im frühen Mittelalter. Wien, 2006, 9-38.

Pollmann, Karla and Otten, Willemien (eds.): The Oxford Guide to the Historical Reception of Augustine. Oxford, 2013.

Rapp, Claudia: Holy Bishops in Late Antiquity: The Nature of Christian Leadership in an Age of Transition. Berkeley and London, 2005.

Reuter, Timothy (ed.): The New Cambridge Medieval History vol. 3, c. 900-c. 1024. Cambridge, 2000.

Reynolds, Susan: There were States in Medieval Europe: A Response to Rees Davies. Journal of Historical Sociology 16(4), 2003, 550-555.

Rowe, Christopher: Introduction, in: Christopher Rowe and Malcolm Schofield (eds.): The Cambridge History of Greek and Roman Political Thought. (5th printing). Cambridge, 2010, 1-6.

Schramm, Percy Ernst: Die deutschen Kaiser und Könige in Bildern ihrer Zeit: 751-1190. (New ed. by Florentine Mütherich). München, 1983.

Skinner, Quentin: Visions of Politics: Volume I: Regarding Method. Cambridge, 2013.

Sot, Michel: Concordances et disconcordances entreculture des élites laïques et culture des élites cléricales à l'époque carolingienne: Jonas d'Orléans et Dhuoda, in: François Bougard, Régine Le Jan and Rosamond McKitterick (eds.): La culture du haut moyen âge. Une question d'élites? Turnhout, 2009, 341-361.

Steinen, Wolfram von den: Der Neubeginn, in: Bernhard Bischoff (ed.): Das geistige Leben, Karl der Grosse: Lebenswerk und Nachleben vol. 2. (3rd ed.). Düsseldorf, 1967, 9-27.

Stone, Rachel: Morality and Masculinity in the Carolingian Empire. Cambridge, 2012.

Story, Joanna (ed.): Charlemagne: Empire and Society. Manchester, 2005.

Trampedach, Kai and Pečar, Andreas (eds.): Theokratie und theokratischer Diskurs: Die Rede von der Gottesherrschaft und ihre politisch-sozialen Auswirkungen im interkulturellen Vergleich. Tübingen, 2013.

Treadgold, Warren: Renaissance before Renaissance: Cultural Revivals of late Antiquity and the Middle Ages. Stanford, 1984.

Ullmann, Walter: The Carolingian Renaissance and the Idea of Kingship. London, 1969.

Ullmann, Walter: Principles of Government and Politics in the Middle Ages. (Repr. of the 1st ed. 1961 with new preface and additional matter). London, 1974.

Wallace-Hadrill, John Michael: Early Germanic Kingship in England and on the Continent: The Ford Lectures Delivered in the University of Oxford in Hilary Term 1970. Oxford, 1971. 


\section{Introduction}

Wallace-Hadrill, John Michael: The Via Regia of the Carolingian Age, in: Idem (ed.): Early Medieval History. Oxford, 1975, 181-200 (first published Oxford 1965, 22-41).

Wickham, Chris: Framing the Early Middle Ages: Europe and the Mediterranean 400800. Oxford, 2005.

Wickham, Chris: Medieval Europe. New Haven, 2016.

Wilks, Michael John: Roman Empire and Christian State in the De Civitate Dei. Augustinus 12, 1967, 489-510.

Wormald, Patrick: Lex scripta et verbum regis: Legislation and Germanic Kingship from Euric to Cnut, in: Peter Sawyer and Ian Wood (eds.): Early Medieval Kingship. Leeds, 1977, 105-38.

Wormald, Patrick: The Making of English Law: King Alfred to the Twelfth Century. Oxford, 1999.

\section{Dictionaries and lexica}

Mayer, Cornelius Petrus et al. (eds.): Augustinus-Lexikon vols. 1-4, Doppelfasz. 5/6. Basel, 1986-2017.

Thesaurus Linguae Latinae Online. München, 1900. 
Part I

Augustine of Hippo 
$\Longrightarrow$ Taylor \& Francis Taylor \& Francis Group http://taylorandfrancis.com 


\section{Influences on the De civitate Dei}

This first part provides an introductory overview of fundamental questions relating to Augustine of Hippo, his late work, the De civitate Dei, and the Roman empire of the fourth and early fifth centuries. It sets the groundwork for a focused and systematic identification of Augustinian ${ }^{1}$ political ideas and political ethics in the Carolingian materials, and presents the themes and concepts of Augustinian thinking that define the analysis of Carolingian texts.

One question that arises, considering Augustine's place in time and his occupation as an early Christian writer, is: what are the main influences on Augustine's De civitate Dei? Other questions that are more specifically concerned with the political ideas and ethics inherent in the De civitate Dei are: what meaning does Augustine attribute to worldly rule and rulership? How does Augustine define and evaluate politically organised communities? An examination of prominent concepts from the De civitate Dei - which I have selected on the basis of their relevance to the Carolingian sources - supports my argument.

\section{Historical and cultural context}

The Latin Father Augustine lived at a time when changes were being made to the administrative, social and cultural structures of the Roman empire. ${ }^{2}$ Although this transformation varied from region to region, it affected the empire everywhere and reshaped the society of Western Europe. ${ }^{3}$ One facet of this transformation between the third and the fifth centuries concerns the settlement of Germanic invaders in Roman provinces from the last quarter of the fourth century onward. ${ }^{4}$ This movement is, despite its significance to the development of the De civitate $D e i,{ }^{5}$ perhaps less relevant to the conceptual questions that are addressed here. What is important, however, is that the settlement of Germanic peoples in the West resulted in a political fragmentation and brought about a cultural separation between the Germanic West and the imperial East. ${ }^{6}$ In the West, a blending of Roman with Germanic elements took place, and "a shared Latin, ecclesiastical culture $[\ldots]^{\prime \prime} 7$ emerged. A more relevant facet of the transformation is the revolution in the Christian 'church's' mode of existence since the beginning of the 
official establishment of Christianity under Emperor Constantine I. ${ }^{8}$ It was the Christian writers of the time who were the main actors involved in reconciling the Christian ideas about the nature of man's existence in politically organised communities with the change in the 'church's' status. ${ }^{9}$ Scholars are now agreed that these writers were not systematic philosophers in regard to their political thought. ${ }^{10}$ Their personalities combined irreconcilable features and tensions, " $[\ldots]$ often unresolved, sometimes unrecognised," consideration to the implications of the political ideas they contained. ${ }^{12}$ In this first part of the book, I explore to what extent Augustine was one of them. It should be noted, however, that it is not pertinent to this research to determine the influence of each of the different strands of thought that were at work in the execution of the De civitate Dei (indeed, it is doubtful whether this could be achieved at all). Therefore, I merely address those elements of influence that have had the most resonance in recent scholarship.

\section{Biographical aspects}

Augustine, born to a Christian mother and a pagan father in the Numidian town of Thagaste in 354, received a traditional education that was marked by "the conservative, strongly literary and rhetorically oriented culture [... ${ }^{\text {"13 }}$ of Late Antiquity. ${ }^{14}$ During the various stages of his life, Augustine's lifestyle, beliefs, occupations and responsibilities changed, and his texts were influenced by various strands of thought. ${ }^{15}$ After a period of attachment to Manichaeism ${ }^{16}$ and years of experience as a teacher of rhetoric (which earned him the official chair of rhetoric in Milan), ${ }^{17}$ Augustine was first a follower of Academic Scepticism and then experienced his conversion to Christianity via neo-Platonic Christianity and the sermons of Bishop Ambrose of Milan. ${ }^{18}$ The conversion brought about a change in lifestyle; Augustine resigned from his public office in 386 and retired to Cassiciacum. ${ }^{19}$ Augustine developed his conception of monastic life $^{20}$ and afterwards became a presbyter at Hippo Regius in $391 .{ }^{21}$ His life changed again when he replaced Valerius as Bishop of Hippo Regius; ${ }^{22}$ during his episcopate (395/396-430), Augustine was part of an intricate network of institutional relationships with imperial and provincial authorities who held responsibilities in the political and military sphere. ${ }^{23}$ Overall, an intellectual development from a Greco-Roman to a Judaeo-Christian perspective via neo-Platonism and St. Paul can be observed. ${ }^{24}$

\section{Authorities and movements}

Augustine composed the De civitate Dei during the period between 412/413 and $426 / 427 .{ }^{25}$ Scholarship refers to the work as an apology, ${ }^{26}$ written in response to a movement of heathen Romans who blamed the sack of Rome by Alaric I in 410 on the official establishment of Christianity in place of the traditional pagan cults. ${ }^{27}$ The De civitate Dei is both a reflection of an intellectual development and "[...] a compendium [...], a major work in which previous thought has matured and settled down." 28 
In the late fourth and the early fifth centuries, two traditions of Western Christian political thought coexisted. ${ }^{29}$ An earlier Christian tradition was shaped by " $[\ldots]$ the imagery of exile running through Old and New Testaments, rabbinic and patristic writings [...]", which "[...] needed re-interpreting in a society governed by Christian emperors and officials [...]." ${ }^{30}$ A later tradition emerged as a "[...] Christian response to the conversion of Constantine and to the progressive Christianisation of the Roman Empire [...]." ${ }^{31}$ In very simple terms, there were the following orientations among Christian writers with an interest in politically organised communities: the apocalyptic and the Eusebian. ${ }^{32}$ The ancient apocalyptic attitude of hostility to the empire saw the 'church' as a persecuted body encircled by an alien world. Representatives of this movement were Donatist theologians in Africa and ascetics in Syria. They stood within the ancient tradition of Christian thought. At the opposite extreme were the followers of Eusebius of Caesarea, ${ }^{33}$ who saw the reign of Constantine I as a fulfilment of what God had conceived in Christ and the Augustus: the uniting of the world under a single Christian order, empire and ruler, whose monarchy on earth mirrored that of God in heaven. Augustine supported neither of these two approaches. He took a critical stance on human society, while at the same time urging the Christian community not to disregard questions relating to worldly affairs, rule and rulership. Markus and Oort agree that the Donatist theologian Tyconius was probably Augustine's main source for this approach. After Tyconius, it is the gnostic religion of Manichaeism that has been most frequently named as the source of the doctrine of the two civitates, and hence as a major influence on Augustine's De civitate $D e i{ }^{34}$ Manichaeism, named after its founder Mani, is based on the primordial and inextinguishable dualism of the spiritual world of light and the material world of darkness. Despite the fact that Augustine's own dualism of good and evil is lasting, extending to the end of world history, it is not primordial. Only the good has existed from the beginning, when God created a world destined to fall apart permanently into His realm and that of Satan. Other scholars have also referred to Plato, Philo, neo-Platonism and the Stoa as elements of influence on the De civitate Dei. ${ }^{35}$ Ambrose is one of the mediators of these philosophical conceptions. ${ }^{36}$ Ambrose re-interpreted Ciceronian Stoicism (e.g. from the De officiis) for a Christian public in his work on Christian morality, the De officiis ministrorum. ${ }^{37}$ He adopted Cicero's key statement that, of the cardinal virtues, iustitia ("justice") is the bond of society, as well as Cicero's maxim that "the foundation of justice is faith (fides). ${ }^{38} \mathrm{He}$ then changed the meaning of fides from a Ciceronian "good faith" into a Christian "trust in Christ."

\section{Marcus Tullius Cicero}

In the following discussion, the republican philosopher and politician Cicero is singled out and studied in relation to political conceptions that occur in the De civitate Dei. Cicero is crucial to this study, as he stood at the beginning of the Latin tradition, shaped Roman political thinking ${ }^{39}$ and had a significant bearing on the De civitate Dei through his De re publica ${ }^{40}$ Cicero deeply influenced Augustine's 
reasoning, terminology and rhetorical mode of expression, ${ }^{41}$ as well as his political discourse and reflection on morality within politically organised communities. Cicero remains an important point of reference throughout this research.

Cicero did not have a rich corpus of Latin literature at his disposal, and therefore he relied heavily on his command of the Greek language. ${ }^{42}$ For example, he built his political ideas on the Greek literature ${ }^{43}$ his notion of the origin of the 'state', expounded in Books I and II of the De re publica, were developed from the Greek historian Polybius. ${ }^{44}$ Like him, Cicero set forth a consideration of the advantages and disadvantages of the three dominant systems of government: monarchy, aristocracy and democracy. ${ }^{45}$ In Book II, however, Cicero enhances the argument of Polybius by saying that it is incorrect to credit the success of the Roman citizens to the Roman constitution and to good fortune. ${ }^{46}$ Rather, the history of the Romans shows that the key element in their rise was from the first the wisdom and moral superiority of individuals. ${ }^{47}$ This enhanced argument shaped Roman political thinking considerably and, as this book argues, played a crucial role in Christian Carolingian political thought too. Cicero's reasoning is that it was his forefathers in Rome who realised Plato's principles of the best 'state' founded on eternal justice ${ }^{48}$ Cicero saw himself as an adherent of the New Academy; he adopted Platonic ideas but tended towards Scepticism. ${ }^{49}$ Cicero looked at philosophy as a communicative tool that helped him to understand problems more thoroughly. As a philosopher, he thought of himself as a Stoic or Epicurean. His way of assessing the pros and cons of every subject matter was exceptional..$^{50}$ Even the cardinal virtues, rooted in Stoic philosophy, as well as other constituents of the Stoic doctrine of virtue, which were traditionally seen as vices (such as the concept of misericors/misericordia), were re-evaluated by Cicero. ${ }^{51}$ This stream of thought reaches Augustine and extends beyond him to include the Carolingians. Cicero's notion that individual citizens were responsible for the Romans' success is authentically reproduced by Augustine, who, when discussing the decline of Roman power, refers both to Cicero and to Sallust. ${ }^{52}$ As far as Cicero's model of social organisation is concerned, the influence of Aristotle's maxim, "man is by nature a political animal," can be found. ${ }^{53}$ In Cicero's De re publica, Scipio makes the following claim:

'Consequently,' says Africanus, 'a 'state' is the affair of a people; however, a people is not any crowd of human beings united in any sort of way, but a crowd of great number associated in a consensus with respect to justice and welfare for the community. But its primary cause of assembling is not so much helplessness as a certain uniting of men as if produced by nature. [... $]^{154}$

It is evident that for Cicero, too, justice is fundamental to the orderly organisation of the 'state'. ${ }^{55}$ The above statement provides the starting point for Augustine's discussion of the definition of the 'state' in the De civitate Dei and his adjustment of Cicero's political ideas for his own Christian argument.

The quotation from the De re publica contains Cicero's definitions of "people" and "state." Cicero insists that a "state" is only the "affair" (res) of a 
people if someone governs it justly - be it a king, a few aristocrats or the people collectively. Otherwise, this body cannot be called a "state." ${ }^{56}$ Cicero deplores the Romans' loss of moral values over the years ${ }^{57}$ and argues for the legitimacy of certain people being in power and ruling over other members of the 'state'. ${ }^{58}$ Cicero illustrates the argument with a series of connected allegories, proceeding from God, who, being the supreme commander, rules over man, to the human spirit that is in charge of the human body, and finally to reason, which controls human desires as well as other evil stirrings of the soul to the benefit of men. ${ }^{59}$

Augustine builds on Cicero's example and argues that true justice in a 'state' can only be achieved if God is the commander of all people; the human spirit is in charge of the human body, and reason controls human desires and other evil stirrings of the soul. ${ }^{60}$ Accepting Cicero's principle that justice is a prerequisite for a 'state', Augustine holds that the Roman power is not and has never been a 'state' ${ }^{61}$ This first description of the 'state' in the De civitate Dei may be understood as being rooted in divine law. ${ }^{62}$ However, Augustine acknowledges that, seen from another angle, the Roman power is nevertheless some kind of 'state'. ${ }^{63}$ He therefore develops a more appropriate definition for such an earthly community in order to make his own statement about the difference between divine and earthly rule. ${ }^{64}$ This second description of the 'state' may be seen as being based on natural law. Augustine keeps Cicero's interpretation of a "state" (res publica) as the "affair of a people" (res populi) 65 but corrects his definition of "people": he writes that "a people is a rational union of a crowd associated in a concordant communion over things that it loves" (populus est coetus multitudinis rationalis rerum quas diligit concordi communione sociatus). ${ }^{66}$ In other words, according to Augustine, a "people" is not "associated in a consensus with respect to justice," 67 but united by a mutual interest in whatever is loved. In this respect, the Roman community is indeed a "people," since it does not matter what the shared interest is that builds its common ground. Accordingly, the "affair" of the Roman people is their "affair" and hence their "state." ${ }^{6}$ Augustine adds that, in the same way as the Romans, other earthly communities - such as the Athenians and other Greeks, the Egyptians and the Babylonians - are a "people" who own a "state"; however, each of these he calls a civitas impiorum ("state of the impious"). ${ }^{69}$ Since their members do not all obey God and acknowledge Him as their supreme commander, these 'states', he argues, lack true justice. ${ }^{70}$ In Book IV, ${ }^{71}$ Augustine addresses the poor ethical basis of regna (here: "autocratic states") in general by comparing them with latrocinia ("bands of robbers").

\section{Notes}

1 By 'Augustinian' I refer to the thought that is manifested in Augustine's later work - in particular the De civitate Dei.

2 Markus 1988, p. 83.

3 Ibid., pp. 83, 87.

4 Ibid., pp. 87-89; King 1988, pp. 123-153.

5 Oort van 2013, pp. 57-62, 86-87; Markus 1988, pp. 104ff.; Baynes 1936, p. 3. 
6 Markus 1988, p. 88; King 1988, pp. 123 ff. However, R. A. Markus notes that "contacts, influences and, especially, a shared antique cultural heritage restricted the extent to which the two worlds came to diverge." Markus 1988, p. 88.

7 Ibid., p. 89.

8 Ibid., pp. 83-87.

9 Ibid., pp. 87, $91 \mathrm{ff}$.

10 Markus 1970, pp. 63-64; Markus 1988, p. 91; Chadwick 1988, p. 20; Oort van 2013, p. 104; Baynes 1936, pp. 3, 15-16. In view of the above, employing a phrase such as "political thought" in a research that is concerned with the reception of Augustine's De civitate Dei in Carolingian texts may seem problematic. However, on the basis of the explanation I provide in the Introduction under Augustine and the Carolingians, I consider it acceptable to resort to this expression for convenience.

11 Markus 1988, p. 91.

12 On Augustine, see Boler 1978, pp. 90-91. On the composition of the De civitate Dei, see also Oort van 2013, pp. 74-77.

13 Markus 1988, p. 89. Roman education rested on the Hellenistic legacy. Ibid. Due to the fact that the Christian 'church' had never conceived a system of education of its own since Constantine I's conversion in 312, the Roman education was adopted in Christian circles. Markus explains that the Roman culture of the fourth century "... was the common property of educated Romans, whether pagan or Christian.” Ibid., p. 85. See also Oort van 2013, pp. 22-23.

14 On Augustine's life, see ibid., pp. 18-57. A comprehensive biographical account is provided by Brown 1979.

15 The point is well made by Markus 1988, p. 103.

16 During the period from 373 to 382, Augustine had been a follower of Manichaeism at the level of auditor ("hearer"). Barnes 1992, p. 7. J. van Oort argues that the "hearer" status should not be underestimated, since it involved adhering to strict rules and assuming important responsibilities. Oort van 2013, pp. 34ff., 44. Oort's research underlines the contribution of Manichaean thought (besides Tyconius) to Augustine's later doctrine of the two civitates. Ibid., pp. 8ff., 274f.

17 Augustine taught rhetoric in Carthage before leaving Africa in 383. He assumed a position as a teacher of rhetoric in Rome and then moved to Milan in 384. Barnes 1992, p. 7. Augustine did not write for and about the same Christian emperor over a long period of time. However, he got a glimpse of what it was like to work as a rhetorician and panegyrist for the imperial court. As his Confessiones demonstrate, the job did not appeal to him. MacCormack 1981, pp. 1ff.

18 The years in Milan (384-387) were crucial to the development of Augustine's later theology and conversion. Augustine was baptised by Ambrose on Easter night in 387. On the contributions of Ambrose and neo-Platonism towards Augustine's alignment with the 'church', see Oort van 2013, pp. 48-55.

19 Ibid., pp. 48, 55; Markus 1970, pp. xv-xvi.

20 The debate surrounding the authenticity of Augustine's work on monasticism is reflected in Leyser 2012, pp. 460-464.

21 Oort van 2013, p. 55; Markus 1970, pp. xv-xvi.

22 Oort van 2013, p. 55.

23 Markus 1970, p. 57; Flasch 2003, pp. 164, 391-393. Oort's overview of Augustine's life and spiritual development does not fully cover the period of his episcopate. Oort van 2013, p. 55. A broad, fact-based account of Augustine's official duties as Bishop of Hippo Regius is provided by Dodaro 1999, pp. 176-184.

24 Augustine's earlier, Platonic interpretation of Christianity involved the all-embracing concept of ordo ("order"), which allowed him to conceive a social order that was accessible to reason and that had its place in the cosmic order. A thorough reading of St. Paul in the years leading up to 400, however, shook Augustine's vision of an ordered rationality of the world. The understanding of original sin and its implications for human life 
led him to the idea that he would formulate in the De civitate Dei: a perfect harmony in the order of this world is not attainable through the rule of wise men who are dedicated to the Christian God. Markus 1970, pp. ixff., 72ff.; Markus 1988, pp. 108-111.

25 N. H. Baynes, in particular, highlights the fact that the work, which was written within a substantial period of time, was published in parts and could not be corrected after completion. Baynes 1936, p. 3. On the composition and characteristics of the De civitate Dei as well as the author's motivation, see Oort van 2013, pp. 57-92; Markus 1970, pp. xi-xiii, xvii, 47, 84ff.; Markus 1988, pp. 104-108; Baynes 1936, pp. 1-6.

26 See Markus 1970, p. 1. Oort also rightly observes that "the City of God is an apology" and that "this character of the work appears to be evident to everyone." Oort van 2013 , p. 166. Already in earlier scholarship before 1900, the De civitate Dei was regarded as an apologetic work. Ibid., pp. 164ff. See also Baynes 1936, pp. 3-5. On the thetic and catechetical aspects of the De civitate Dei, see Oort van 2013, pp. 169-196. However, Oort's overall argument is, as often, unassertive and contradictory, as he writes: "Generally speaking the first part of the De civitate Dei is mainly apologetic, the second thetic. However, there are also many apologetic passages in the second part, while in the first ten books a number of thetic expositions can be indicated." Ibid., p. 76.

27 Markus 1970, p. 47; Markus 1988, pp. 104-108; Baynes 1936, pp. 1-6. Although Oort refers to the barbarian raids as the immediate incentive for the work, he convincingly draws on existing scholarship (e.g. Brown) and Augustine's texts to confirm that the $D e$ civitate Dei is not the after-effect of any one specific event and would have been written even without the fall of Rome. Oort van 2013, pp. 57-62, 86-87. Markus mentions two other important motivations for writing: first, in the De civitate Dei, Augustine addresses, inter alia, heathen imperial officials and defines politically organised communities in a manner that would prove the Christians' unreserved allegiance to the Roman empire. Markus 1970, pp. xi-xiii; see also Chadwick 1988, pp. 19-20. Second, the work is unmistakably an attack on Roman imperialism, lust for domination and "pride" (superbia). Markus 1970, pp. xvii-xx.

28 Oort van 2013 , p. 88 . The question of whether early medieval readers were able to distinguish between the early and the late work of Augustine is raised by Leyser 2012, p. 452.

29 Markus 1988, p. 92.

30 Ibid., pp. 86-87. On the public influence and responsibilities of bishops, see Dodaro 1999, pp. 176-184. An overview of Augustine's use of the Old and New Testaments is given by Oort van 2013, pp. 312-322. In summary, Oort says: “... we should realize that when Augustine referred to biblical passages in the framework of his concept of the two cities, he took them indiscriminately from the New and the Old Testament, but much more often from the latter." Ibid., p. 312.

31 Markus 1988, p. 92.

32 The following summary of the two opposed directions, and of Augustine's own view, based on Tyconius, is taken from Markus 1970, pp. 49-50, 55-56, 76-77; Chadwick 1988, pp. 19-20; Oort van 2013, pp. 154-163, 254-275; Baynes 1936, p. 5.

33 In the De civitate Dei, Augustine uses Eusebian thought as well, though in a much more intellectual sense, drawing on Eusebius' Chronicon via Jerome. Markus 1970, p. 6.

34 Manichaeism and its influence on Augustine's De civitate Dei is treated extensively in Oort van 2013, pp. 8-15; 199-234.

35 Ibid., pp. $10 \mathrm{ff}$.

36 Ibid.

37 On this discussion, see Markus 1988, pp. $97 \mathrm{ff}$.

38 Cicero's definition of iustitia ("justice") is treated in detail in Atkins 2013, pp. $202 \mathrm{ff}$.

39 Schofield 1999, pp. 178, 180, 193.

40 See the seminal work by Suerbaum 1977, pp. 1-70, 170-220. The dialogue De re publica was published shortly after completion in $51 \mathrm{BC}$. A great part of the work was lost throughout the Middle Ages (except for a section from Book VI, which was known 
through a commentary by Macrobius, who lived during the fourth/early fifth century). As a result, later references to Cicero's text, in particular the quotations and summaries by Lactantius and Augustine, became relevant. Thus, the influence of the De re publica on the thought after Augustine was mainly indirect. It was not until 1819/1820 that a fragmentary third of the total De re publica was rediscovered. Ibid., p. 193; Atkins 2010 , p. 490.

41 Oort van 2013, pp. 22-23, 90-91; Markus 1970, pp. 58-59, 64-65. According to S. G. MacCormack, the panegyrists of the fourth century particularly used Cicero's linguistic style. Augustine himself was acquainted with Cicero's language through his rhetorical training and teaching. MacCormack 1981, pp. 1-2, 5.

42 Quintus Ennius was before Cicero.

43 Although Cicero's texts are strongly shaped by Plato, Aristotle and Hellenistic philosophy (Atkins 2013, pp. 7-8, 17ff., 61ff., 81-85, 85-96, 189ff.), there has been debate as regards the discrimination between Greek, Roman and, more specifically, his own (Ciceronian) thought. M. Schofield, in his analysis of Cicero's definition of res publica as res populi, first maintains that in the dialogue, Cicero's definition operates " ... as a criterion of legitimacy." Schofield 1999, p. 178. Second, he asserts that “... this interest in discriminating between set-ups on grounds of legitimacy is a distinctively Roman and Ciceronian input into the theory of Rep., not one inherited from whatever Greek models Cicero was using." Ibid. Schofield's claims are well argued. However, there is one aspect in which his argument could be more precise. Schofield reformulates his two claims again in the text. Ibid., pp. 179, 180, 189. But what is missing is a clear distinction between what, according to him, is "Roman" and what is "Ciceronian" about the concern for the legitimacy of government(s) in the De re publica. Schofield says "... Cicero effectively creates an entirely new theory, cast in a legal vocabulary which has no parallel in Greek generally or in Greek political philosophy in particular. Its legal inspiration makes it a distinctively Roman contribution to political thought." Ibid., p. 189. Later on he writes: “... Cicero's treatment of res publica has a quite different structure from Platonic and Aristotelian political philosophy, despite his debts to them. What makes the difference is the conceptual framework of Roman law, for it is Roman law which enables questions to be formulated about the rights a free people has to own, lend, transfer or place in trust powers conceived on the model of property." Ibid., p. 193. It remains unclear whether it is Cicero who permits a preoccupation with the problem of legitimacy, or Roman law.

44 Ibid., p. 183; Dvornik 1966, p. 469. T. Wiedemann observes that Greek writers were generally more interested in the Roman political system and in constitutional analysis than Latin authors. Wiedemann 2010, p. 526. Wiedemann agrees with J. Procopé, who writes: "Attempts to explain Rome in terms of Greek constitutional theory were of limited use." Procopé 1988, p. 29.

45 On the role of these systems of government for Cicero's definition of res publica as res populi, see Schofield 1999, pp. 185-187, 189. The function of the Senate in Cicero's constitutional scheme and Cicero's justification of aristocratic rule within the framework of popular sovereignty are discussed in ibid., pp. 190-193. See also Atkins 2013, pp. 80-104; Dvornik 1966, p. 469.

46 Procopé 1988, pp. 28ff.; Atkins 2013, p. 82; Dvornik 1966, p. 469.

47 Ibid.

48 Atkins 2013, p. 82.

49 Atkins 2010, pp. 498, 503-504.

50 Ibid., pp. 503-504.

51 AL vol. 4, 1/2 2010-2013, pp. 34-35.

52 Civ. II 21 , pp. 79-80, V 12, pp. 215-217, V 18, pp. 227-228. This is a theme that runs through Roman historical writing. Schofield comments on Cicero's reflections on Roman politics: "As so often in Roman writers, the focus is moral rather than constitutional: in this case the loss of a common experience and commitment which shaped and 
stiffened character." Schofield 1999, p. 181. Wiedemann confirms that creating theoretical premises or frameworks for politics was not a Roman characteristic. Wiedemann 2010, p. 517. The Romans judged their system: "[ ...] not with reference to a constitution or constitutional ideal, but with reference to the exempla provided by its greatest player." Ibid., p. 521. This is evident in Livy. Ibid., pp. 522-524. While Sallust drew on Posidonius when expounding the idea that the fall of Carthage determined the collapse of Roman political morality, he added other explanatory factors (e.g. luxury) that he regarded as crucial to the moral decline. Ibid., p. 527. Tacitus, the last significant historian of the Roman empire, was influenced by Sallust. Ibid., p. 528. His works, too, were concerned with morality and idealised republican virtues (in the Germania Tacitus highlighted certain values and noble principles of the Germanic peoples that were similar to the old Roman virtues). The imperial lives of Suetonius, too, although part of a different genre (biography), "contain no explicit theorizing about imperial power." Ibid., pp. 530-531. Augustine himself uses exempla from both the pagan Roman Republic and the Christian empire. See Civ. II 29, V 15, and, above all, Civ. V 25, 26 on the Christian Roman emperors Constantine I and Theodosius I. See also Markus 1970, pp. 57ff.

53 Martin 1972, p. 216; Dvornik 1966, p. 468. On the impact of Hellenistic, Aristotelian and Platonic political philosophy on Cicero, see Schofield 1999, pp. 183-184. Aristotle's maxim is adopted by Augustine. Markus 1988, pp. 109-110; Baynes 1936, p. 16.

54 'Est igitur' inquit Africanus 'res publica res populi; populus autem non omnis hominum coetus quoquo modo congregatus, sed coetus multitudinis iuris consensus et utilitatis communione sociatus. Eius autem prima causa coeundi est non tam imbecillitas, quam naturalis quaedam hominum quasi congregatio. ...' Rep. I 39, p. 28; see also Civ. II 21, p. 81. On Cicero's definition of res publica, see also Atkins 2013, pp. 129-131.

55 Ibid., pp. 144-152; Dvornik 1966, p. 468.

56 Civ. II 21, p. 81.

57 Ibid., pp. 79, 81-82.

58 Ibid., pp. 80-81, XIX 21, pp. 390-391. Ambrose, too, integrated this discussion into his Christian moral system. Markus 1988, pp. 96-98.

59 Civ. XIX 21, p. 391.

60 On Augustine's translation of the classical Ciceronian definition of the res publica into Christian terms, see also Markus 1970, pp. 64-67.

61 Civ. XIX 21, p. 391, XIX 23, p. 399.

62 A conclusive explanation of how Augustine develops two antithetical Christian notions of nature and natural law on the basis of Cicero's twofold conception of natural law is provided by M. J. Wilks: Cicero, who regards justice as a quality of nature and, "[...] inherent in natural law [...]," distinguishes between rational natural law and non-rational/unreasoning natural law, which correlate with the categories of civilised and brute creatures, respectively. Drawing on St. Paul's idea of the right-willing and wrong-willing selves in man, Augustine adopts a conception of nature and natural law in a non-divine sense alongside the Roman proposition of natura, id est, Deus, which suggests that "[...] the truly natural [is] the divine, because it [is] divinity which [gives] things their real nature." Nature or natural law in a divine sense relates to "[...] man in his pristine perfection [...]," while nature or natural law in a non-divine sense is associated with the "[...] corrupted man [...]" after the Fall. Wilks 1967, pp. 495-497. Above, I follow Dvornik's terminology of "natural law" and "divine law" for "nature and natural law in a non-divine sense" and "nature and natural law in a divine sense." Dvornik 1966, p. 845. See also Markus 1988, p. 111; Markus 1970, pp. 47ff., 84-98, 208f. A more detailed discussion of Cicero's conception of "natural law" can be found in Atkins 2013, pp. 155-187; Atkins 2010, pp. 499-500.

63 Civ. II 21, p. 83.

64 Civ. XIX 24. 
65 Ibid., p. 400.

66 Ibid., p. 400, 11. 6-7.

67 Civ. II 21, p. 81.

68 Civ. XIX 24, p. 400.

69 Ibid. I agree with R. Martin that Augustine highlights the decline that the Roman 'state' has undergone since the antique Roman Republic. Ibid., p. 400, 11. 16-22. However, Martin speaks of a general, "[...] obvious preference [...]" on the part of Augustine "[...] for the antique Roman republic [...]" Martin 1972, p. 208. I do not support this reading because the fact that Augustine concludes the chapter by ranking the Romans among other peoples, i.e. the Athenians, other Greeks, the Egyptians and Babylonians, as belonging to the civitates impiorum, reduces the worth of his previous endorsement. Civ. XIX 24, p. 400, 11. 25-401, 11. 1-3. The Romans are equalled to these other peoples for the reason that they are heathens and do not accept the Christian God as their highest authority. This logic inevitably dictates the superiority of Christian politically organised communities over heathen ones and the moral superiority of the Christian Roman empire over the pagan Roman Republic. The moral superiority of Christian 'states' over all other politically organised communities is confirmed at Civ. V 19, p. 230, 11. 21-24. Nevertheless, I agree with Markus that Augustine does not assume any turning-point in Roman history with the Christianisation of the Roman empire. Markus 1970, pp. 56ff. Wilks, moreover, says that Augustine "[...] tended to remain aloof from the Roman empire even in its Christian form [...]" Wilks 1967, p. 490. However, Wilks then argues that Augustine saw the quality of the heathen Romans' virtues as spoilt by the lack of iustitia - a concept that could only be brought to fruition within a Christian community. Ibid., pp. 491-493. The result is that still a very high moral value is attached to the Christian 'state', which is not demonstrably attributable to the De civitate Dei.

70 Civ. XIX 24, pp. 400-401.

71 Civ. IV 4, pp. 150-151.

\section{Bibliography}

\section{Primary sources}

Augustinus Hipponensis: Sancti Aurelii Augustini episcopi De civitate Dei libri XXll 2 vols. Bernhard Dombart et Alfons Kalb (recogn.). (5th ed.). Stuttgart, 1993.

Marcus Tullius Cicero: De re publica; De legibus; Cato maior de senectute; Laelius de amicitia. J. G. F. Powell (recogn. brevique adnotatione critica instruxit). Oxford and New York, 2006.

\section{Secondary sources}

Atkins, E. Margaret: Cicero, in: Christopher Rowe and Malcolm Schofield (eds.): The Cambridge History of Greek and Roman Political Thought. (5th printing). Cambridge, 2010, 477-516.

Atkins, Jed W.: Cicero on Politics and the Limits of Reason: The Republic and Laws. Cambridge, 2013.

Barnes, Timothy David: Augustine Symmachus, and Ambrose, in: Joanne McWilliam (ed.): Augustine: From Rhetor to Theologian. Waterloo, Ontario, 1992, 7-13.

Baynes, Norman Hepburn: The Political Ideas of St. Augustine's De Civitate Dei. Historical Association Pamphlet 104, 1936, 3-18.

Boler, John: Augustine and Political Theory. Mediaevalia: A Journal of Medival Studies 4, 1978, 83-97. 
Brown, Peter: Augustine of Hippo: A Biography. (1st ed. 1967, in this ed. 1969 repr.). London, 1979.

Chadwick, Henry: Christian Doctrine, in: James Henderson Burns (ed.): The Cambridge History of Medieval Political Thought c. 350-c. 1450. Cambridge, 1988, 11-20.

Dodaro, Robert: Church and State, in: Allan Fitzgerald (ed.): Augustine Through the Ages: An Encyclopedia. Grand Rapids, MI, 1999, 176-184.

Dvornik, François: Early Christian and Byzantine Political Philosophy: Origins and Background 2 vols. Washington, D. C., 1966.

Flasch, Kurt: Augustin: Einführung in sein Denken. (3rd, supplemented ed.). Stuttgart, 2003.

King, Paul David: The Barbarian Kingdoms, in: James Henderson Burns (ed.): The Cambridge History of Medieval Political Thought c. 350-c. 1450. Cambridge, 1988, 123-153.

Leyser, Conrad: Augustine in the Latin West, 430-ca. 900, in: Mark Vessey (ed.): $A$ Companion to Augustine. Chichester, 2012, 450-464.

MacCormack, Sabine G.: Art and Ceremony in Late Antiquity. Berkeley, CA and Los Angeles, CA, 1981.

Markus, Robert Austin: Saeculum: History and Society in the Theology of St Augustine. Cambridge, 1970.

Markus, Robert Austin: The Latin Fathers, in: James Henderson Burns (ed.): The Cambridge History of Medieval Political Thought c. 350-c. 1450. Cambridge, 1988, 92-122.

Martin, Rex: The Two Cities in Augustine's Political Philosophy. Journal of the History of Ideas 33, 1972, 195-216.

Oort van Johannes: Jerusalem and Babylon: A Study into Augustine's City of God and the Sources of His Doctrine of the Two Cities. (Repr. of the 1st ed. 1991). Leiden, 2013.

Procopé, John: Greek and Roman Political Theory, in: James Henderson Burns (ed.): The Cambridge History of Medieval Political Thought c. 350-c. 1450. Cambridge, 1988, 21-36.

Schofield, Malcolm: Saving the City: Philosopher-Kings and Other Classical Paradigms. London, 1999.

Suerbaum, Werner: Vom antiken zum frühmittelalterlichen Staatsbegriff: Über Verwendung und Bedeutung von 'res publica, 'regnum', imperium' und 'status' von Cicero bis Jordanis. (3rd revised ed.). Münster Westf., 1977.

Wiedemann, Thomas: Reflections of Roman Political Thought in Latin Historical Writing, in: Christopher Rowe and Malcolm Schofield (eds.): The Cambridge History of Greek and Roman Political Thought. (5th printing). Cambridge, 2010, 517-531.

Wilks, Michael John: Roman Empire and Christian State in the De civitate Dei. Augustinus 12, 1967, 489-510.

\section{Dictionaries and lexica}

Mayer, Cornelius Petrus, Feldmann, Erich and Chelius, Karl Heinz (eds.): AugustinusLexikon vols. 1-4, Doppelfasz. 5/6. Basel, 1986-2017. 


\section{Augustine's stance on worldly rule and his assessment of politically organised communities in the De civitate Dei}

This chapter seeks to determine what worldly rule means to Augustine of Hippo in the work De civitate Dei. The investigation explores questions such as: how critical was Augustine of worldly rulership? To what extent was such a criticism a viable political stance in Augustine's time? Dvornik notes that a number of medieval theologians (e.g. Gregory the Great and Isidore of Seville) and modern scholars alike have deduced from the De civitate Dei that Augustine, due to his spiritualisation of concepts such as "justice," "peace" and "virtue," and his criticism of the pagan Roman 'state', took an utterly negative stance towards worldly rulership. ${ }^{1}$ Dvornik maintains, however, that such authors were oblivious to Augustine's acknowledgement of the idea of a 'state' as being built on natural law. ${ }^{2}$ In my study of the De civitate Dei, I argue that Augustine's judgment on worldly rulership is not at all free from ambiguity. A conflict in the author's argument is revealed; there is a clear tension between approval of the supreme worldly power of Christian and (to a limited extent) pagan rulers and harsh criticism towards any form of worldly social organisation, government and power. ${ }^{3}$ This conflict is best visible in Augustine's assessment of politically organised communities. It is this elaborate evaluation of different historically significant worldly 'states' that appears to be most characteristic of Augustine's political reflections in the De civitate Dei. I expose the conceptual thought forming forces that are at play in his attempt to integrate polytheistic and monotheistic, heathen and Christian 'states' into God's plan and to provide a comprehensive framework in which politically organised communities can be compared. The conflict that unfolds in the De civitate Dei expresses Augustine's dilemma between the determination to define more clearly the idea of a Christian worldly 'state' and the inclination to negate everything that is temporal and imperfect.

Having examined Augustine's criticism of Cicero's definition of "state," the question arises whether Augustine recognised any worldly 'states' worthy of the name. Book IV, ${ }^{4}$ taken in isolation, provides a clear negative response. Augustine observes: "In the absence of justice, what are realms, therefore, but big bands of robbers? For what are bands of robbers themselves but small realms?"5 Since, according to Augustine's conclusion in Book XIX, ${ }^{6}$ all worldly 'states' are unjust, there are apparently none that deserve a better title than latrocinia ("bands of robbers"). 
However, the question may be rephrased, and one may ask whether, according to Augustine's judgment, some worldly 'states' are superior to others from a moral point of view. Following Augustine's new definition of "people" in Book XIX, Augustine indeed affirms that people or 'states' can be judged according to the things they love as a community. Thus, the more virtuous a people or 'state' is, the more honourable the matter is that is valued in common. ${ }^{7}$ This shows that a classification of worldly 'states' according to moral standards is only possible for Augustine because he recognises a definition of the "state" based on natural law alongside the other definition based on divine law. That Augustine makes a correction of his first definition of "state" in order to be able to rank some worldly 'states' higher than others is expressive of the conflict inherent in his work between an acknowledgement and a denial of worldly power.

K. Jaspers wrote about Augustine:

Nothing is easier than to find contradictions in Augustine. We take them as features of his greatness. [...] He makes us aware of the provocative question: Is there a point, a limit, where we are bound to encounter contradiction? And of the answer: Yes, wherever moved by the source of being and the unconditional will within us, we seek to communicate ourselves in thought, that is to say, in words. In this realm, freedom from contradiction would be existential death and the end of thinking itself. ${ }^{8}$

H. Arendt agreed with Jaspers' claim that a system cannot be forced on Augustine's views. This is manifested in her doctoral work on Augustine's use of the concept of "love," where, in order to gain insight into the existential origins of Augustine's ideas, she made an effort to reveal the discrepancies and inconsistencies that are inherent in Augustine's thought. She showed that the question about "love" and the relevance of the concept of "neighbour" is doubly posed and doubly answered by Augustine. This, Arendt declared, is due to the fact that for Augustine there are two ways of explaining humanity's origin.

Firstly, Augustine enquires about the being of man as an individual. In this enquiry, the question about being is identical with the question of where this being comes from or what its source is. The answer is that God is the source of each and every individual. The individual then becomes decisive for neighbourly "love" in his concern for the other's salvation. However, no consideration is given to the other person in his capacity as our neighbour if he is not in the same spiritual world with us, i.e. does not believe in the same God.

Secondly, when Augustine asks about the origin of the human race, his answer is that the origin (as distinct from the self-sameness of God) lies in the common ancestor of us all. While according to the first sense, man is seen as isolated and coming into a world that is perceived as a desert, according to the second sense, he is seen as belonging to mankind and to the world by generation. ${ }^{9}$

Hence, depending on how humanity's origin is explained, the rationale for "love" for the neighbour changes. If God is seen as the source of each and every individual, the individual's deeds of charity are done not for the sake of the 
neighbour, but for the sake of God, i.e. because the individual loves God and seeks to connect with God. Conversely, if humanity's origin is traced to a common ancestor, the deeds of charity are done because, on the grounds of kinship, the neighbour is part of the same human race. It is clear that to Augustine, under the precondition that God is the source of each and every individual, deeds of charity on the grounds of kinship cannot legitimately be called "love." The first answer to humanity's origin, according to Arendt, reflects the divine dimension of the concept of "love," while the second answer reflects its existential or natural dimension.

An analogy can be found when exploring the manner in which Augustine understood the concept of 'state'. According to Augustine, not only two "loves" but also two "states" (civitates) emerged from the first man, Adam. ${ }^{10}$ In the De civitate Dei, Augustine affirms:

Accordingly, two loves have brought forth two 'states', the love for oneself up to the contempt of God brought forth the earthly ['state'], the love for God up to the contempt of oneself, however, the heavenly ['state']. ${ }^{11}$

Here, too, Augustine has two ways of explaining what a 'state' is, depending on whether God or the common human ancestor is seen as the origin of the human race. If God is the origin, the definition is as follows (in line with Cicero): "a crowd of human beings associated in a consensus with respect to justice."12 This justice, for Augustine, is only achievable if all members of the 'state', including its ruler, place themselves completely under the authority of God. If the common human ancestor is the origin, the appropriate definition reads: "a rational union of a crowd associated in a concordant communion over things that it loves." ${ }^{.13}$ Augustine adds that a worldly 'state' is superior to another if the matter it commonly loves manifests higher ethical principles. It is clear that, according to Augustine, if justice, which can only be achieved on condition that all members of the 'state' plus its ruler place themselves fully under the authority of God, is taken as the precondition for a 'state', no worldly community could possibly pass for a 'state'.

In the De civitate Dei, Augustine looks at worldly 'states' from an eschatological point of view; all worldly 'states' are planned and controlled by the Christian God. His scheme and will are known to Him alone and impenetrable to the people in this world. ${ }^{14}$ God awards both good and evil people with rulership ${ }^{15}$ which reflects the existence of morally superior and inferior 'states'. Why a 'state' has certain properties and not others and why worldly power is granted to a certain person remains obscure. Yet Augustine maintains that worldly power is given to good and evil people without distinction in order that true Christians may question such temporal privileges. ${ }^{16}$

Augustine's assessment of worldly 'states' can be gleaned from the first books of the De civitate Dei about the Roman and other secular powers, their moral standards and the relationship between power and justice (particularly Books IV and $\mathrm{V}$ ), and from the last books concerned with the genesis, growth and interaction of the spiritual 'states' civitas Dei and civitas terrena (mainly Books XV, XVIII and XIX). In general and without regard to the great complexity of Augustine's 
representation, the manner in which the earthly powers are laid out in these books suggests that there is a certain hierarchy of 'states'.

According to this hierarchy, the 'state' of the monotheistic Jewish nation is ranked at the bottom. Of course, this is a simplified rendition of Augustine's general judgment on the Jewish people. Augustine was well aware that the Jews were the first receivers of salvation (since Abraham); God established the Old Covenant with His people, the people of Israel. ${ }^{17}$ In other words, in salvation history, the Jews play a much more important role than, for example, the heathens. Augustine's thinking behind ranking the Jews below the heathens in his evaluation of worldly 'states' must have simply been the following: the heathens who converted to Christianity are in a better position than the Jews, who have not become Christians. Augustine, especially in Book IV of the De civitate Dei, praises the Jews for being the only people who did not initially worship demons and sacrifice to false gods but served the one God. ${ }^{18}$ In order to indicate to the people on earth that all earthly goods lie in His hands, He gave power to His people, freed them from the Egyptians in miraculous ways and let them spread, prosper and win wars. ${ }^{19}$ Unfortunately, Augustine points out, the Jewish 'state' only lasted as long as it maintained the right form of belief. He rebukes them by saying that, had the Jews not turned away from the one God and worshipped tin gods and foreign idols, ${ }^{20}$ and had they not in the end brought about Christ's death, ${ }^{21}$ their ancient realm, as prosperous as it once was, would have been preserved. ${ }^{22}$ Instead, he explains, the Jews are now deprived of their homeland and live scattered all over the world..$^{23}$ Their destiny, he claims, is in agreement with divine providence. The fate of the Jews fits into God's plan in so far as, by their dispersal, the divine prophecies of the coming Messiah contained in the books of the Jews are made known to the whole world, and the growth of the 'church' of Christ on earth is launched. ${ }^{24}$

Otherworldly 'states' founded before the Romans are rated higher than the Jews in terms of moral standards. Among others, Augustine mentions the Egyptians, ${ }^{25}$ the Persians ${ }^{26}$ and, following the Roman historians Varro ${ }^{27}$ and Sallust, the Sicyonians, the Athenians and the Latins.$^{28}$ However, Augustine argues that these appear rather small and unimportant next to two large, supreme and historically more significant 'states'. For divine providence has decreed that there are two superior temporal realms, namely the pagan 'states' of the Assyrians and the Romans. ${ }^{29}$ Augustine presents the polytheistic Assyrians in the East as the typos ("pre-image") and the polytheistic/pre-Christian Romans in the West as the antitypos ("counter-image"). ${ }^{30}$ Both 'states' are noteworthy and meaningful because they are two large and, in their own way, good ${ }^{31}$ worldly 'states' which parallel the civitas Dei. ${ }^{32}$ Their function for Christianity is that, due to their longevity, size and influence, they were able over a long period of time to secure peace among the earthly community, which is often divided by enmity and war. ${ }^{33}$ What is more, the citizens of these worldly 'states' are to be taken as an example by the citizens of the civitas Dei. ${ }^{34}$ In one instance, Augustine, inspired by the Bible, uses Babylon as a pars pro toto name for any supreme worldly 'state' whose peace can provide stability to the civitas Dei ${ }^{35}$ Several other passages demonstrate how important safeguarding peace on earth is to Augustine and that, according to 
him, Christianity cannot prosper without peace. ${ }^{36}$ The significance of these two superior temporal realms in the context of God's providential plan is as follows: the Assyrian empire as the typos is relevant for events appertaining to the Old Testament. Augustine indicates that first Abraham was born in the Assyrian 'state' and then his and Sarah's long-awaited heir Isaac, who himself had the twins Esau and Jacob together with his wife Rebecca. ${ }^{37}$ The Roman empire as the antitypos must then be relevant for the New Testament. Augustine explains that, because of the virtues of the early Romans during the Roman Republic (Sallust), God allowed Christ to be born under their rule..$^{38}$ In some places in the De civitate Dei, the Roman 'state' clearly appears as the greater and more powerful of the two. ${ }^{39}$ However, it must be pointed out that already in Chapter 2 of Book XVIII, the author specifies that his illustration of the civitas terrena as running parallel to the civitas Dei will, because of the density of available historical sources, concentrate first and foremost on the Roman power. ${ }^{40}$ Augustine, indeed, praises the Romans for having initially possessed the exceptional virtues and skills for which God rewarded them ${ }^{41}$ granting them laws and a 'state' of immense proportions, which would vanquish the great evils among the subordinate races and bring peace to the entire world for a very long time.$^{42}$ Yet other passages in the De civitate Dei include not only praises but also highly sarcastic remarks about the Romans' achievements. ${ }^{43}$ These are good examples of the tension within the author's argument and indicate that the text is unresolved as to whether the Romans' success is to be praised to some extent or condemned altogether. In comparison with the Assyrians, Augustine believes that the Romans faced the bigger challenge and did the better job in terms of the military subjection of other races. According to him, the Romans had to deal with much more powerful enemies who were better organised in their defence than the enemies of the Assyrians had been. ${ }^{44}$ All in all, Augustine concludes that, because of the virtues of the early Romans during the Roman Republic (Sallust), the heathen Romans were superior to the Jews in moral behaviour, and hence were rewarded by God by being given the important task of defeating the Jews, who did not recognise Christ. ${ }^{45}$ In addition, the pagan 'state' of the Romans had the honour of having had Christ live under its rule. ${ }^{46}$

The approach of Eusebius was not structured in the same way by an opposition between the eschatologically relevant, supreme worldly powers of the Assyrians and the Romans - the Assyrian 'state' as the oriental typos meaningful to the Old Testament (birth of Abraham ${ }^{47}$ ) and the Roman 'state' as the occidental antitypos critical to the New Testament (birth of $\mathrm{Christ}^{48}$ ). For Eusebius, the Roman empire was mainly crucial for having had a facilitating role in the spread of Christianity and perhaps even a sort of joint mission. ${ }^{49}$ For him, the fact that Christ was born soon after the reign of Augustus was part of God's plan. The empire, by bringing peace among previously warring nations, accelerated the spread of the Gospel. The Assyrians as a worldly 'state' relevant for events in the Old Testament seem not to come into his field of vision at all. In relation to the idea of the breaking up of the Jewish kingdom as a sign of the coming Messiah, which was given great prominence by Eusebius, ${ }^{50}$ Augustine goes further by bringing in the Romans and explaining that they are morally superior to the Jews, who did not acknowledge 
Christ, and thus were in a position to defeat them and have Christ under their rule. ${ }^{51}$ Eusebius, like Augustine, mentioned the collapse of the Jewish nation as a portent of the coming Messiah. However, when discussing the fate of the Jewish nation, Eusebius did not involve the heathen Romans in this manner by juxtaposing their moral behaviour. Eusebius did judge worldly power, but his judgment focused on the rulers alone and depended on their success and changing stance on Christianity. ${ }^{52}$ The comparative analysis of pagan and Christian 'states' in terms of moral standards is a distinctive feature of Augustinian ${ }^{53}$ political thought.

At the top of the pyramid of worldly 'states', according to Augustine, are the Christian 'states'. The Christian Roman empire and emperors are much less criticised than the pagan Roman 'state'; in fact, they are mainly praised. Regarding the Christian emperors, Augustine declares:

For we do not call some Christian emperors happy for the reason that they have either ruled longer or have left behind ruling sons after a peaceful death, or that they have subdued enemies of the 'state' or been able both to provide against and oppress hostile citizens who were rising up against them.

Even some worshippers of demons have deserved to receive these and other favours or comforts in this miserable life, those who do not belong to the realm of God to which these [Christian emperors] belong; and this has been done by the forbearance of He Himself, lest those who believed in him desired these things from him as the highest goods.

No - rather we call them happy if they rule justly, if they do not elevate themselves among flatterers who do obeisance and debase themselves to the allegiances of those who humble themselves too much, and are mindful that they are human beings; [we call them happy] if they make their power the maid-servant of His majesty for the veneration of God, extended to the highest degree; if they fear, love and worship God; if they love that realm more, where they do not fear having co-heirs; if they avenge in a more measured manner, forgive easily; if they exert the same revenge for the necessity of governing and protecting the 'state', not for grudges of hostilities which should be set aside; if they exercise the same indulgence not to let injustice go unpunished, but for the hope of correction; if they - since they are mostly compelled to decide harshly - compensate by the mildness of forbearance and the abundance of favours; if luxury is restrained by them, although it could be more unrestrained; if they prefer ruling over their vicious desires than ruling over any tribes; and if they do all these things not because of any zeal for worthless glory, but because of their love for eternal happiness; if they do not fail to offer their true God the sacrifice of humility and compassion as well as prayer for their sins.

Such Christian emperors we call happy now because of hope, [and] hereafter when they in fact will be [happy], when what we expect will have come to pass. ${ }^{54}$

In this passage as well as in the last paragraph of Chapter 19 of Book $\mathrm{V},{ }^{55}$ proof can be found that Augustine sees emperors - including Christian emperors - as 
subordinate to God. However, in spite of this evidence, these lines (and the last two chapters of Book V of the De civitate Dei on the Christian Roman emperors Constantine I and Theodosius ${ }^{56}$ ) unmistakably disclose that Augustine still holds a certain admiration for temporal gifts and greatness. The extraordinary luck and achievements of both of these rulers incline him to think of Christian emperors as particularly felices ("happy"), although he draws attention to the fact that there were also less "happy" Christian emperors. ${ }^{57}$

Augustine remarks that the Emperor Constantine I was exceptionally talented and reigned for a long time (306-337), including as sole ruler (324-337). ${ }^{58} \mathrm{He}$ emerged victorious from wars and was always successful in subduing tyrants. ${ }^{59}$ Notably, Augustine mentions Constantine I's old age and his peaceful, natural death, which seem to be particularly precious gifts to him. ${ }^{60}$ In Augustine's view, Constantine I's greatest achievement was the creation of a Christian capital city, Constantinopolis (inaugurated in 330) as the Christian equivalent of the heathen Rome or as the "Christian Rome."

Emperor Theodosius I - emperor in the East from 379 onwards and sole ruler from 394 to 395 - is praised in the De civitate Dei above all for his piety, humility and charity. ${ }^{62} \mathrm{He}$, Augustine relates, accommodated Valentinian II, the orphaned little brother of the Western Emperor Gratian, who was murdered by the Western usurper Magnus Maximus in 383 in his part of the empire, and avenged the murder of Gratian by eliminating Magnus Maximus in 388, and returned to him his share. ${ }^{63}$ In a battle at the Frigidus River in 394, Theodosius I then destroyed the pagan tyrant Eugenius, who, after the death of Valentinian II in 392, was illegitimately made Roman emperor in the West on Valentinian's behalf. ${ }^{64}$ After having received a Christian prophecy of victory, Augustine writes, Theodosius I was so confirmed in his Christian faith that he defeated the powerful enemy mainly by prayer. ${ }^{65}$ Augustine first and foremost praises Theodosius I's strong Christian belief, his strict prohibitions on heathen practices ${ }^{66}$ and his contributions to the consolidation of the Christian 'church' on earth. ${ }^{67}$ Considerable emphasis is placed on the emperor's humility due to his willingness to forgive and repent after having punished the Thessalonians excessively for committing a crime. The group of bishops to which Ambrose belonged, and which prompted the emperor's noble gesture of penitence, is mentioned. Augustine expands on this incident when he maintains:

But what was more admirable than his [Theodosius I's] religious humility, when, by the protest of some who adhered to him, he was urged to take vengeance for the very grave crime of the Thessalonians, for which he had already promised indulgence since the bishops interfered, and corrected by the ecclesiastical instruction thus exercised penitence, so that the people praying for him shed more tears when seeing the imperial sublimity prostrated, than it feared the imperial sublimity enraged when sinning?

He carried these good deeds - as well as others like them, which would be tedious to recount - with him out of this temporal society of any high quality and human sublimity; the reward for which deeds is eternal happiness, whose giver is God to the truly pious alone. ${ }^{68}$ 
Two virtues, considered by Augustine as essentials of Christian rulership, can be found in Chapters 24 and 26 of Book V of the De civitate Dei: ${ }^{69}$ misericordia ("forbearance") and humilitas ("humility"). Augustine lays down that the "happy kings" should counterbalance their usually strict judgment by "forbearance" and should not fail to offer God the sacrifice of "humility" for their sins. The concept of misericors/misericordia is, according to the Latin Stoic tradition, the equivalent of the Greek noun हैं $\lambda \varepsilon \varsigma_{.}{ }^{70}$ Stoic philosophers such as Seneca regarded clementia as a minor and misericordia as a major vitium. They saw misericordia as an emotion distinguished from reasoning or knowledge and hence condemned it as irrational. Cicero, by contrast, celebrated Caesar's misericordia as one of the ruler's most noble attributes. Early Christian philosophers, including Augustine, of course understood misericordia as a virtue. However, the concept was more often used with reference to God, whose misericordia forgives the people's sins. With reference to the Christians, misericordia was believed to manifest itself in the people's compassionate actions and alms for the poor. ${ }^{71}$ In the AugustinusLexikon s.v. misericordia, Drecoll affirms that the distinction between misericordia and iustitia or iudicium is integrated in Augustine's vocabulary. ${ }^{72}$ Augustine takes the juxtaposition of misericordia and iustitia in $G n 24,49$ and 47,29sq. as the earliest evidence for this fundamental distinction. God is at the same time the deus ultionum ("God of vengeance") (see Ps 93,1) and the fons misericordiarum ("fountain of forbearance"). Furthermore, Augustine contrasts the iustitia punientis ("justice of the punishing") with the misericordia liberantis ("forbearance of the freeing") (lib. arb. 3,55; c. Adim. 7). Drecoll notes that Augustine depicts misericordia and iustitia or iudicium as two essential aspects of the image of God, and thus accuses the Manichaeans of eliminating the aspect of iudicium from the conception of God (Ps 100,1). ${ }^{73}$ In the De civitate Dei, Augustine picks up Cicero's reflections on misericordia. A prominent passage in Chapter 5 of Book IX defends Cicero's argument on misericordia against traditional Stoic belief. ${ }^{74}$ In the Augustinus-Lexikon s.v. humilitas,${ }^{75}$ it is stated that according to Augustine, humilitas is a typical feature of Christianity; in contrast to Christian writers before Augustine, who conferred a certain importance on the ethics of the pagans, he is eager to present humilitas as a characteristic element of Christian ethics. It is further mentioned that Augustine particularly insists on the humilitas of rulers. In his Sermones $(69,2)$, he stresses that without humilitas, greatness is not conceivable: "Do you want to be great, so start in the smallest." 76 The clearest evidence of Augustine's linking of humilitas with Christian rulership is in Chapter 26 of Book V, where Augustine alludes to the submission of Emperor Theodosius I to Bishop Ambrose.

The analysis of different temporal 'states' in the De civitate Dei has firstly revealed that, according to the author, there are more and less virtuous worldly 'states', of which, however, none is perfect in the sense that it would succeed in placing itself fully under God's authority (as demanded in Chapters 21 and 23 of Book XIX ${ }^{77}$ ). Secondly, it has become evident that Augustine also sees temporal gifts and greatness as meaningful. This has particularly been shown to be the case as far as the successes of the Christian Roman emperors Constantine I and 
Theodosius I are concerned, and, to some extent, also with respect to the skills of the heathen Romans. Augustine's acknowledgement of temporal gifts and greatness reflects his dilemma between approval of worldly rulership and supreme power on the one hand and harsh criticism towards any form of worldly government on the other. The last paragraph of Chapter 19 in Book $\mathrm{V}^{78}$ is probably most expressive of Augustine's rating of heathen and Christian worldly 'states': here, the author explicitly asserts that, according to the standards of a certain kind of worldly 'state', the heathen Romans had indeed a good 'state', which was of use to the earthly community. Yet, nuancing what he says, Augustine claims that a human being without true faith in the Christian religion can never be genuinely virtuous. Such limited virtue, however, is in Augustine's eyes still better than no virtue at all (the Jews lost theirs by abandoning the one God and killing Christ). He concludes that it is the greatest bliss for the condition of human beings on earth if people who have been granted a strong belief in Christianity, and hence true virtue and a calling for ruling over nations, come to power. ${ }^{79}$ These are the Christian emperors. The last two chapters of Book V of the De civitate Dei ${ }^{80}$ deal with the two pre-eminent Christian Roman emperors Constantine I and Theodosius I. In these chapters, Augustine clearly praises both emperors. However, it must be said that Augustine's praise is not general, as it is the case in panegyric, ${ }^{81}$ but that it is rather particular since it focuses on very specific merits of these emperors. ${ }^{82}$ The emperors' achievements in the promotion of the Christian faith - in the case of Theodosius I the destruction of images of heathen Gods, the ban on the ancient cult of the gods and of Arianism in the East, as well as his humility and willingness to repent and forgive - are mentioned. ${ }^{83}$ Augustine's account of the emperors' qualities and achievements recognises deeds for which there is irrefutable historical evidence. It seems that the author is, within reasonable limits, trying to find virtues that he can legitimately attribute to Constantine I and Theodosius I. Even though Augustine's evaluation of their rule is positive overall, he chooses a formulation that gives the reader scope for deciding about how to judge worldly Christian rulership. He ends the record of Theodosius I's accomplishments by writing: "[...] the reward for which deeds is eternal happiness, whose giver is God to the truly pious alone." ${ }^{84}$ Neither here nor anywhere else in the De civitate Dei is it stated that a Christian Roman emperor will, according to Augustine, be rewarded with eternal happiness. Augustine's opinion on the status of Christian rulers is not explicitly expressed. It is only natural that Augustine, writing as a bishop at a time when the Christians were still aware of the preceding centuries of persecution, should praise certain achievements of contemporary emperors that contributed to the strengthening of the Christian faith.

Moreover, it is obvious that from the moment a ruler adopts a certain doctrine, its adherents are less likely to judge him unfavourably. That the continued existence of the earthly 'church' as the 'state' religion, and the spread of the correct Christian doctrine under the protection of the government (i.e. the 'state's' ruler), were important to Augustine is plain for a number of reasons. Throughout his life as a Christian, Augustine had been rigorous in combating what according to him was heresy. For Augustine, heresy was a real problem of the 'church' as an 
earthly institution. Augustine was well aware of the fact that worldly powers were always involved when decisions concerning questions of faith were to be made. This explains Augustine's praise of the Christian Roman emperors Constantine I and Theodosius I for certain, very specific actions in support of the Christian 'church' as an earthly institution. According to Augustine, however, all members of a 'state', including its ruler, must place themselves completely under the authority of God in order to achieve justice, the essential precondition for any 'state' that can legitimately be called a civitas Dei. This, according to Augustine, cannot be achieved on earth.

\section{Notes}

1 Dvornik 1966, pp. 844-850. J. Boler and Martin argue along these lines. According to Boler, "[...] Augustine thinks that government is a necessary evil. That alone would be enough to put him in opposition to "classical" theories that take the political life as the form of full human development." Boler 1978, p. 93. Martin concludes that "[...] Augustine rejected the classical idealization of the state; this is far more central than how he stood on Cicero's definition. There is a gulf of radical discontinuity between Augustine and classical politics." Martin 1972, p. 216.

2 Dvornik 1966, pp. 84-850.

3 This is in line with Boler, who argues: "[...] the fact is that he [Augustine] did not offer Christians any hope for or encouragement towards establishing a political program for the betterment of man.

Perhaps this conflict of tendencies in Augustine's attitudes cannot be resolved." Boler 1978, pp. 90-91.

4 Civ. IV 4.

5 Remota itaque iustitia quid sunt regna nisi magna latrocinia? quia et latrocinia quid sunt nisi parva regna? Ibid., p. 150, 11. 19-20.

6 Civ. XIX 24.

7 Ibid., p. 400. However, what the highest social and political ambition is that a 'state' can possibly achieve is not determined in the De civitate Dei. On this subject, see Martin 1972, pp. 213ff.

8 Cited in Arendt 1996, p. 207.

9 Ibid., pp. 111-112.

10 Civ. XII 28, pp. 555-556, XIV 28, pp. 56-57. On Augustine's theory of "love" and re-definition of the res publica in terms of the "loves" of its members, see also Markus 1970, pp. 66-71; Markus 1988, pp. 105-108; Martin 1972, pp. 202, 209ff.; Baynes 1936, pp. 16-17.

11 Fecerunt itaque civitates duas amores duo, terrenam scilicet amor sui usque ad contemptum Dei, caelestem vero amor Dei usque ad contemptum sui. Civ. XIV 28, p. 56, 11. 24-26.

12 Civ. II 21, pp. 79-83, XIX 21, pp. 389-392, XIX 23, pp. 393-399.

13 Civ. XIX 24, p. 400. This definition includes both "loves": the "love" for oneself and the "love" for God. See Schofield 2010, pp. 668-671.

14 Civ. IV 33, p. 188.

15 Ibid.

16 Ibid.

17 See Rom, 1-2 Cor, Gal.

18 Civ. IV 34, p. 189, V 12, p. 211.

19 Civ. IV 34, pp. 188-189, XVIII 20, pp. 281-282.

20 Civ. IV 34, pp. 188-189. 
21 Ibid., p. 189.

22 Ibid.

23 Ibid.

24 Civ. XVIII 46, pp. 328-329, 47, p. 331.

25 Civ. XIX 24, p. 400.

26 Civ. V 21, p. 233.

27 Varro is an important reference in the De civitate Dei. His work Antiquitates Rerum Divinarum is known primarily via Augustine, who uses it in the De civitate Dei as a focus of his critique of pagan theology in Books VI and VII. Varro's De philosophia provides a record of all conceivable positions in ethics (amounting to 288 positions). Augustine has recourse to Varro in Book XIX of the De civitate Dei where he proves that only the Christian response to the question of the supreme good is feasible. Schofield 2010, p. 666; see also Oort van 2013, pp. 65-72.

28 Civ. XVIII 2, pp. 257-258.

29 Civ. XVIII 2, pp. 256-259, 22, p. 284, 27, p. 292, V 13, p. 217, 21, pp. 232-233, IV 6-7, pp. 152-154. Augustine defines the two supreme powers as follows: "[...] Babylonia, quasi prima Roma [...]" and "[...] Roma quasi secunda Babylonia [...]" Civ. XVIII 2, p. 258, 11. 22-26. Elsewhere he specifies: "[...] condita est civitas Roma velut altera Babylon et velut prioris filia Babylonis [...]" Civ. XVIII 22, p. 284, 11. 4-5. See also Oort van 2013, p. 71 (note 307). By Assyria, Augustine means Babylonia prima, hence his alternate use of Assyria and Babylonia. Ibid., p. 71.

30 Civ. XVIII 2, pp. 256-259, 22, p. 284, 27, p. 292, V 13, p. 217, IV 6-7, pp. 152-154.

31 Civ. V 19, p. 230.

32 Civ. XVIII 1, pp. 255-256, 2, p. 259.

33 Civ. XVIII 2, p. 256, 22, p. 284, XV 4, p. 63.

34 Civ. V 16, p. 221, 17, pp. 222-223, 18, pp. 227-228.

35 Civ. XIX 26, p. 402. A more detailed account of Augustine's reflections on pax ("peace") can be found in Markus 1970, pp. xi-xx; Markus 1988, pp. 110-111.

36 Civ. XV 4, p. 63, 6, p. 66, XVIII 22, p. 284.

37 Civ. XVIII 2, p. 257, 3, pp. 259-260.

38 Augustine writes about the Assyrians and the Romans: "[...] ac per hoc per ea tempora isti velut fontes prophetiae pariter eruperunt, quando regnum defecit Assyrium coepitque Romanum; ut scilicet, quem ad modum regni Assyriorum primo tempore extitit Abraham, cui promissiones apertissimae fierent in eius semine benedictionis omnium gentium, ita occidentalis Babylonis exordio, qua fuerat Christus imperante venturus, in quo implerentur illa promissa, ora prophetarum non solum loquentium, verum etiam scribentium in tantae rei futurae testimonium solverentur." Civ. XVIII 27, p. 292, 11. 4-13.

39 Civ. V 13, p. 217, XVIII 22, p. 284.

40 Civ. XVIII 2, p. 258.

41 Civ. V 13, pp. 217-218, 15, pp. 220-221, 16, p. 221, XVIII 22, p. 284.

42 Civ. V 13, p. 217, XVIII 22, p. 284.

43 Civ. V 12, pp. 211-217, 17, pp. 221-223, 18, pp. 223-228, 19, pp. 228-231.

44 Civ. XVIII 22, p. 284.

45 Civ. V 18, p. 228, XVIII 46, pp. 328-329.

46 Civ. XVIII 27, p. 292, 46, pp. 328-329.

47 Civ. XVIII 2, p. 257, 3, pp. 259-260.

48 Civ. XVIII 27, p. 292.

49 On Eusebius' view of the Roman empire and its relation to Christianity, see Procopé 1988, p. 32; Nicol 1988, pp. 51-55; Markus 1988, pp. 93-104; Garnsey 2010, pp. 411-414.

50 Markus notes: "Few Christian writers went as far as Eusebius in applying messianic categories to the rule of the Roman emperors." Markus 1970, p. 50.

51 Civ. XVIII 46, pp. 328-329. 
52 Campenhausen von 1963, p. 63.

53 By 'Augustinian', I refer to the thought that is manifested in Augustine's later work - in particular the De civitate Dei.

54 Neque enim nos christianos quosdam imperatores ideo felices dicimus, quia vel diutius imperarunt vel imperantes filios morte placida reliquerunt, vel hostes rei publicae domuerunt vel inimicos cives adversus se insurgentes et cavere et opprimere potuerunt.

Haec et alia vitae huius aerumnosae vel munera vel solacia quidam etiam cultores daemonum accipere meruerunt, qui non pertinent ad regnum Dei, quo pertinent isti; et hoc ipsius misericordia factum est, ne ab illo ista qui in eum crederent velut summa bona desiderarent.

Sed felices eos dicimus, si iuste imperant, si inter linguas sublimiter honorantium et obsequia nimis humiliter salutantium non extolluntur, et se homines esse meminerunt; si suam potestatem ad Dei cultum maxime dilatandum maiestati eius famulam faciunt; si Deum timent diligunt colunt; si plus amant illud regnum, ubi non timent habere consortes; si tardius vindicant, facile ignoscunt; si eandem vindictam pro necessitate regendae tuendae que rei publicae, non pro saturandis inimicitiarum odiis exerunt; si eandem veniam non ad inpunitatem iniquitatis, sed ad spem correctionis indulgent; si, quod aspere coguntur plerumque decernere, misericordiae lenitate et beneficiorum largitate compensant; si luxuria tanto eis est castigatior, quanto posset esse liberior; si malunt cupiditatibus pravis quam quibuslibet gentibus imperare et si haec omnia faciunt non propter ardorem inanis gloriae, sed propter caritatem felicitatis aeternae; si pro suis peccatis humilitatis et miserationis et orationis sacrificium Deo suo vero immolare non neglegunt.

Tales christianos imperatores dicimus esse felices interim spe, postea re ipsa futuros, cum id quod expectamus advenerit. Civ. V 24, p. 236, 1. 27-p. 237, 1. 26.

55 Civ. V 19, p. 230.

56 Civ. V 25, 26.

57 Civ. V 25, p. 238.

58 Ibid. On Constantine I, see also Rosen 2013, pp. 105ff., 221ff., 362-364; Nicol 1988, pp. 51-57.

59 Civ. V 25, p. 238. On Constantine I's defeat of Maxentius and Licinius, see Rosen 2013, pp. 128-129, 142ff., 150-153; Stephenson 2010, pp. 145-149, 181-183; Nicol 1988, p. 53.

60 To a certain extent, Augustine's representation generates the understanding that such gifts are a sign of divine favour. Civ. V 25, p. 238.

61 Ibid. On the foundation, significance and symbolic value of Constantinopolis, see Stephenson 2010, pp. 190-211; Nicol 1988, pp. 53-54; Dam van 2014, pp. 83-94.

62 On Theodosius see Markus 1988, pp. 103ff.; Errington 2006, pp. 212-259.

63 Civ. V 26, pp. 238-239.

64 Ibid., p. 239.

65 Ibid.

66 Ibid., pp. 239-240.

67 Ibid. See also Markus 1988, pp. 103-104, 113-114.

68 Quid autem fuit eius religiosa humilitate mirabilius, quando in thessalonicensium gravissimum scelus, cui iam episcopis intercedentibus promiserat indulgentiam, tumultu quorundam, qui ei cohaerebant, vindicare compulsus est et ecclesiastica cohercitus disciplina sic egit paenitentiam, ut imperatoriam celsitudinem pro illo populus orans magis fleret videndo prostratam, quam peccando timeret iratam?

Haec ille secum et si qua similia, quae commemorare longum est, bona opera tulit ex isto temporali vapore cuiuslibet culminis et sublimitatis humanae; quorum operum merces est aeterna felicitas, cuius dator est Deus solis veraciter piis. Civ. V 26, p. 240, 11. 16-27.

69 Civ. V 24, pp. 236-237, Civ. V 26, pp. 238-242.

70 AL vol. 4, 1/2 2010-2013, p. 34. 
71 Ibid., pp. 34-35.

72 Ibid., p. 38.

73 Ibid.

74 Civ. IX 5, pp. 374-376.

75 AL vol. 3 2004-2010, pp. 448, 451, 453.

76 Magnus esse vis, a minimo incipe.

77 Civ. XIX 21, p. 391, XIX 23, p. 399.

78 Civ. V 19, p. 230.

79 Ibid., p. 230, 11. 21-24. This passage invalidates the following statement by Martin: "It is important $[\ldots]$ to note that Augustine nowhere makes an explicit distinction between heathen and Christian states [...]. This fact in itself and his obvious preference for the antique Roman republic [...] make it difficult to see how the Christianized State interpretation has come to have the credibility that it has in recent scholarship." Martin 1972, p. 208.

80 Civ. V 25, 26.

81 Eusebius may serve as an example. Of course, very few speeches by Eusebius actually survive. There are mainly the Tricennial Orations and arguably the Vita Constantini which have some panegyrical elements. For instance, the first oration in the Tricennial Orations, the De laudibus Constantini, does offer some specific praise of Constantine I, but also offers very general remarks. In particular, it offers general remarks about tyrants and bad rulers, rather than good rulers, but it does contrast them with good rulers, using that to shed some light on what makes a good ruler. (It is worth adding that the traditional Tricennial Oration is actually two separate speeches - at least that is the current consensus.) For further reading, see the translation and commentary by H. A. Drake (In Praise of Constantine) as well as the Life of Constantine.

82 This is reflected in Markus 1970, pp. 51ff, 72. However, on p. 55 Markus argues that Augustine saw the Roman empire as "theologically neutral," which I think is an exaggerated rendering of Augustine's sober appraisal of the Theodosian establishment of Christianity. See also Markus' discussion in Markus 1988, pp. 103-108.

83 A recent biographical account of Theodosius I is provided by H. Leppin. See Leppin 2003, pp. 76, 115-127, 165-167, 230.

$84[\ldots]$ quorum operum merces est aeterna felicitas, cuius dator est Deus solis veraciter piis. Civ. V 26, p. 240, 11. 26-27.

\section{Bibliography}

\section{Primary sources}

Augustinus Hipponensis: Sancti Aurelii Augustini episcopi De civitate Dei libri XXll 2 vols. Bernhard Dombart et Alfons Kalb (recogn.). (5th ed.). Stuttgart, 1993.

Eusebius Caesariensis: In Praise of Constantine. A Historical Study and New Translation of Eusebius'. Tricennial orations by Harold Allen Drake. Berkeley, 1976.

Eusebius Caesariensis: Life of Constantine. Introduction, transl. and commentary by Averil Cameron and Stuart George Hall. Oxford, 1999.

\section{Secondary sources}

Arendt, Hannah: Love and Saint Augustine. Edited and with an interpretive essay by Joanna Vecchiarelli Scott and Judith Chelius Stark. Chicago, IL, 1996.

Baynes, Norman Hepburn: The Political Ideas of St. Augustine's De civitate Dei. Historical Association Pamphlet 104, 1936, 3-18. 
Boler, John: Augustine and Political Theory. Mediaevalia: A Journal of Medival Studies 4, 1978, 83-97.

Brunhölzl, Franz: Der Bildungsauftrag der Hofschule, in: Bernhard Bischoff (ed.): Das geistige Leben, Karl der Grosse: Lebenswerk und Nachleben vol. 2. (3rd ed.). Düsseldorf, 1967, 28-41.

Campenhausen von, Hans: The Fathers of the Greek Church. Revised transl. from the German by L. A. Garrard. London, 1963.

Dam van, Raymond: "Constantine's Beautiful City": The Symbolic Value of Constantinople. Antiquité Tardive 22, 2014, 83-94.

Dvornik, François: Early Christian and Byzantine Political Philosophy: Origins and Background 2 vols. Washington, D. C., 1966.

Errington, R. Malcolm: Roman Imperial Policy: From Julian to Theodosius. Chapel Hill, NC, 2006.

Garnsey, Peter: Introduction: The Hellenistic and Roman Periods, in: Christopher Rowe and Malcolm Schofield (eds.): The Cambridge History of Greek and Roman Political Thought. (5th printing). Cambridge, 2010, 401-414.

Leppin, Hartmut: Theodosius der Grosse. Darmstadt, 2003.

Markus, Robert Austin: Saeculum: History and Society in the Theology of St Augustine. Cambridge, 1970.

Markus, Robert Austin: The Latin Fathers, in: James Henderson Burns (ed.): The Cambridge History of Medieval Political Thought c. 350-c. 1450. Cambridge, 1988, 92-122.

Martin, Rex: The Two Cities in Augustine's Political Philosophy. Journal of the History of Ideas 33, 1972, 195-216.

Nicol, Donald MacGillivray: Byzantine Political Thought, in: James Henderson Burns (ed.): The Cambridge History of Medieval Political Thought c. 350-c. 1450. Cambridge, 1988, 51-79.

Oort van, Johannes: Jerusalem and Babylon: A Study into Augustine's City of God and the Sources of His Doctrine of the Two Cities. (Repr. of the 1st ed. 1991). Leiden, 2013.

Procopé, John: Greek and Roman Political Theory, in: James Henderson Burns (ed.): The Cambridge History of Medieval Political Thought c. 350-c. 1450. Cambridge, 1988, 21-36.

Rosen, Klaus: Konstantin der Grosse: Kaiser zwischen Machtpolitik und Religion. Stuttgart, 2013.

Schofield, Malcolm: Epilogue, in: Christopher Rowe and Malcolm Schofield (eds.): The Cambridge History of Greek and Roman Political Thought. (5th printing). Cambridge, 2010, 661-671.

Stephenson, Paul: Constantine: Roman Emperor, Christian Victor. New York, 2010.

\section{Dictionaries and lexica}

Mayer, Cornelius Petrus, Feldmann, Erich and Chelius, Karl Heinz (eds.): AugustinusLexikon Vols. 1-4, Doppelfasz. 5/6. Basel, 1986-2017. 


\section{Concepts of Augustinian political thought}

This chapter lays out concepts of Augustinian ${ }^{1}$ political thought that I have selected on the basis both of their prominence in the De civitate Dei and their relevance to the Carolingian source material. The first section explores Augustine's terminology for types of politically organised communities; the second section is dedicated to the concept of dispensatio; the third section discusses the related concepts of felix/felicitas and beatus/beatitudo; and the final section examines the implications of iustitia and pax.

\section{Terminology for types of politically organised communities}

In her research on the concept of "love" in Augustine of Hippo's writing, Arendt drew attention to problems regarding terminology - among them also Augustine's terminological inconsistency. Arendt wrote that the Latin translation of the Greek New Testament could accommodate three Greek terms for "love" - ع $\rho \omega \varsigma, \sigma \tau o \rho \gamma \eta ́$ and $\alpha \gamma \alpha ́ \pi \eta$ - with the corresponding Latin terms being amor, dilectio and caritas. She remarked, moreover, that Augustine's use of these terms was quite flexible since he frequently used them synonymously and even emphasised this fact repeatedly. Still, Arendt said, Augustine had three terms at his disposal where we have only one, at best two, in modern English: "love" and "charity." She explained that Augustine generally, but not consistently, used these three terms in different contexts. ${ }^{2}$

The same terminological problem is relevant to our analysis of Augustine's conception of different types of politically organised communities. In his work $D e$ civitate Dei, Augustine reflects on various types of political entities and, accordingly, avails himself of different Latin terms when talking about these different forms of government. Again, Augustine is not always consistent in the terminology he employs. On that account, a brief examination of the various words Augustine uses is undertaken in order to come closer to Augustine's understanding. The chief Latin terms that occur in the De civitate Dei are: regnum, imperium, res publica, civitas and societas.

Regnum, which could mean "the office of king," "monarchy," "royal state," "kingdom," "realm," "autocratic/despotic rule/state" or "tyranny," "the power of king," "kingship" or "political control," and is a derivative of rex ("king," 
"leader," "the sovereign ruler of a state/people"), ${ }^{3}$ appears in the De civitate Dei in the books on politics and the Roman empire and other worldly empires, as well as in the books that are concerned with the Christian significance of history and the two spiritual 'states', the civitas Dei and civitas terrena. ${ }^{4}$ That is to say, regnum can be found as both a political and spiritual/religious concept. ${ }^{5}$ When regnum does not refer to a 'state' or community ruled by a leader, it can usually be translated as "the power of king" or "political control"; 6 in the other cases regnum generally means "autocratic state" or "realm" (which means that, according to Augustine, regnum is not necessarily a "royal state," but may very well be any kind of realm, including a "world power" or an "empire" such as that of the Romans, governed by imperatores and dominant over other 'states' and their rul$\left.\mathrm{ers}^{7}\right)$. Regnum then generally marks an entity that is controlled by someone. The following phrases and expressions provide evidence:

Deus $[\ldots]$, in cuius potestate sunt regna omnia ${ }^{8}$ regnum Dei ${ }^{9}$

regnum $[\ldots]$ a Saule rege sumpsit exordium ${ }^{10}$

regnum Christi. ${ }^{11}$

Another passage ${ }^{12}$ that touches upon the etymology and meaning of rex, by drawing on Cicero, clearly indicates that Augustine sees regnum as closely related to and as a derivative of rex.

The word imperium, which holds the meanings "supreme power (of Roman emperors)," "(military) command," "rule," "empire" and "world power," is a derivative of imperare ("command," "rule (over)") 13 and primarily occurs in the books ${ }^{14}$ dealing with politics and the characteristics of Roman power. Only rarely is imperium found as a spiritual/religious concept. ${ }^{15}$ Strikingly, this is the case at the beginning of the De civitate Dei (in the last chapter of Book II), where Augustine urges the Romans to abandon the cult of the gods. In fact, imperium occurs as part of a quote from two verses of Virgil's Aeneid, which have been adapted by Augustine. Virgil's original text says: "For these [Romans] I set neither limits of government nor time limits; I have given an empire without end."16 These verses belong to Book I of the Aeneid and are included in Jupiter's speech to Venus. It shows Venus the future of Aeneas and the Trojans. Augustine, in the De civitate Dei, instead, attempts to convince the reader that if envious Juno already begrudges Aeneas and the Trojans their earthly happiness, which is the seat of power in Rome, she will feel a lot more bitter when learning about the humans' felicitas aeterna ("eternal happiness"). Therefore, the humans must break away from their old gods and strive after "[...] the one and true God who sets neither limits of government nor time limits, He will give an Empire without end." 17 Augustine adapts Virgil in a similar way as he avails himself of Cicero for his own argument. That Augustine uses imperium in a spiritual sense is an exception in the De civitate Dei. It can be explained by examining more closely both contexts - the context in which Augustine draws on Virgil, and the context in which Virgil writes these verses. In Book II of the De civitate Dei, Augustine denounces 
the Roman gods and criticises their values, exhorts the Romans to abandon these gods, defends the Christian religion and draws attention to its healing powers. In the first ten books of the work, in general, Augustine explains why the heathen Romans need to give up their gods, and why they are wrong to assume that Roman decline, being attributable to the fact that some citizens have left their old gods in order to join Christianity, has only started after the emergence of Christianity. Augustine's reasoning when using Virgil suggests that he is seeking to prove the unreliability of the Roman gods. He draws attention to the fact that Juno was, from the very outset, against the Romans' rise to power. What Augustine wants to say is that, if it was in their power, some of these gods would certainly never have allowed the Romans to achieve world domination. Consequently, no conclusive evidence can be presented that the Christians are to blame for the overthrow of the seat of power in Rome. The context in which the verses feature in the Aeneid is, correspondingly, a forecast of the future Roman world power. The aim Augustine pursues by referring to the eternal realm of the Christian God as an imperium is mainly to offer a comprehensible and possible alternative for the heathen Romans who are distraught over the limitedness and temporary nature of their military power. Augustine uses the heathen Romans' vocabulary to build a bridge between the two antithetical ideas - the idea of the supreme Roman military power and the idea of the transcendent realm of the Christian God. In most of the other instances in which imperium occurs in the De civitate Dei, however, it is used in the worldly sense of "empire" or "world power" and often refers to the Roman empire ${ }^{18}$ (imperium Romanum), and sometimes also to other supreme 'states'19 in history (i.e. 'states' dominant over others in power and influence). Furthermore, imperium frequently means "supreme power (of Roman emperors)" is notable about the forms in which imperium emerges in the De civitate Dei is that they almost exclusively carry a military connotation. This is in agreement with the meaning of imperium that was most common in the Classical Roman Period. ${ }^{22}$ It is therefore not surprising that in the De civitate Dei, imperium hardly ever has a spiritual or religious meaning. It also suggests that Augustine's spiritual community, the civitas Dei, is incompatible with any form of military power.

The term res publica, which generally means "activities affecting the whole people," "affairs of state," "the resources of the state," "body politic," "the (Roman) state" and "(free) state," ${ }^{23}$ is encountered above all in the books ${ }^{24}$ on the decay and characteristics of the Roman 'state' as understood by Cicero. In most cases, res publica has the meaning of "state" or "body politic" and sometimes "political career," 25 "the authority of the state," "26 "public life",27 and "the resources of the state." 28 To the worldly 'states' that are called res publica in the De civitate Dei belong the early Christian Roman 'state'29 and, above all, the pagan Roman 'state'. ${ }^{30}$ What is intriguing is that in the De civitate Dei, res publica twice ${ }^{31}$ stands for the civitas Dei. In one of these instances, Augustine explicitly comments on his use of the word res publica. He writes:

[...] the 'state', whose founder and ruler is Christ, if it pleases to call also this a 'state', seeing as we cannot deny that it is the affair of a people. But if this 
name, which has become common in other places and circumstances, is perhaps too remote from the use of our discourse, in that 'state' there is certainly true justice $[\ldots .]^{32}$

This remark indicates that it is slightly unusual in Latin to apply the concept of res publica to a spiritual/religious body. Augustine himself finds his own wording slightly awkward. The reason why Augustine here chooses res publica to refer to the civitas Dei is that immediately before he treated Cicero's notion of the 'state' in his discussion of Cicero's work De re publica, and now he picks up his argument with regard to the civitas Dei. The concept of res publica was established by Roman political thinkers and refers to the 'state' in its political structure. The root of the adjective publicus, $-a$, -um is populus..$^{33}$ Apart from the fact that publicus and populus are cognates, the phrase res publica itself does not make any direct reference to the people or citizens of a 'state'. However, res publica relates to the populus in the sense that it describes the 'state' as a public body, which in some respects belongs to the populus and is at their disposal. It is not, though, the individual citizen to whom the res publica belongs, but rather the populus as a whole. ${ }^{34}$ The res publica demands from the populus a certain ethical behaviour in turn, for example, to refrain from violent private conflicts and enmities or to sacrifice their lives for the "state'. ${ }^{35}$ In this regard, res publica is to be seen as a value concept.

Civitas may carry the meaning of "citizenship," "citizenry," "citizens," "commonwealth," "body politic," "community based on law," "state"36 or "city," and is a derivative of civis ("citizen"). ${ }^{37}$ In Chapter 15 of Book I of the De civitate Dei, Augustine himself writes that "[...] civitas is nothing else but a concordant crowd of people" (aliud civitas non sit quam concors hominum multitudo). ${ }^{38}$ This definition is later expanded as follows: "[...] civitas [...] is nothing else but a crowd of people brought together by some bond of association [...]" (civitas [...] nihil est aliud quam hominum multitudo aliquo societatis vinculo conligata). ${ }^{39}$ The similarity between the latter, more refined definition of civitas and Augustine's definition of res publica adapted from Cicero is undoubtedly striking. K. Flasch remarks that civitas is the Latin equivalent of the Greek $\pi$ ó $\lambda$ s ("city-state," "city," "state"), and hence denotes the 'state' in legal rather than in local terms. ${ }^{40} \mathrm{~K}$. F. Morrison also observes that civitas is very much a legal corporation. ${ }^{41}$ As a concept, civitas includes the citizen and his rights in the 'state' or, to put it more precisely, stands for the citizens as a collective, who have joined together and formed a community based on a valid legal order, with a common intent and to their mutual benefit. Furthermore, Flasch comments that because of the close link between politics and cult in antiquity, civitas may also signify "cult community." 42 In view of the above, civitas appears to be the most suitable term for labelling the two transcendent communities, the civitas Dei and the civitas terrena, since in these civitates too the people are united by two different devotional purposes: to live either after God or after the people. ${ }^{43}$ In line with my own reasoning, Oort observes:

The City of God is an apologetic work, and in his very choice of the term civitas Dei the author is defending himself against the pagan opposition. 
While his opponents argued that Christianity is not a community-building force, the name civitas Dei is the self-assured proclamation of the Christian idea of community: the civitas surpassing all civitates is of divine origin. While all civitates (poleis!) are linked to their particular cult of gods, the civitas Dei is united with the true God. ${ }^{44}$

My argument is that, had res publica carried the additional meaning of "cult community" (as does civitas), Augustine would have chosen res publica in the sense of his remodelled definition based on Cicero. ${ }^{45}$ In that case, the meaning of both transcendent concepts would have been complete; the "people" is neither "associated in an agreement with respect to justice" (Cicero), nor "united by a mutual interest in whatever is loved" (Augustine adapted from Cicero), but assembled by either the worship of the true Christian God (in the civitas Dei) or the worship of idols (in the civitas terrena). ${ }^{46}$ It is thus the particular nuance in the meaning of civitas, which conveys the idea of association on the grounds of a common cult or religion, that must have been decisive in Augustine's choice of civitas for denoting the two spiritual communities.

Augustine was still strongly influenced by the Greek notion of $\pi 0 \lambda \imath \tau \varepsilon i \alpha$ ("the conditions and rights of the citizen," "citizenship"). Apart from the Greek concepts of $\pi \delta \lambda_{\imath} \varsigma$ or $\pi \delta \lambda \imath \tau \varepsilon i \alpha$ and $\varepsilon^{\prime} \theta v \eta$ (pl.) (which in the singular form corresponds to the Latin populus and means "people," and in the plural form means "races," "tribes," "nations" ${ }^{47}$ ), it would be beyond the scope of this book to trace any further Latin social and political terms back to the Greek language. In the Hellenistic period, the cities were of primary importance. Christianity

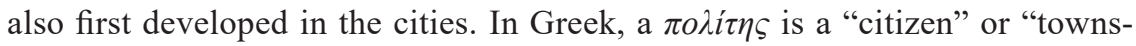
man"; the Latin equivalent is civis. In the Classical Roman Period, foreigners first had to move from the countryside to the cities, and then learn Latin (in the West) or Greek (in the East) if they wanted to qualify for Roman citizenship. The Latin equivalent of the Greek है $\theta v \eta$ (pl.) is gentes (pl.) ("races," "tribes," "nations"). ${ }^{48}$ The definition of gentes relevant to Augustine is "less influential groups of people." Hence, both gentes and $\varepsilon \theta v \eta$ refer to a less dominant group of people, such as country people, in contrast to the urban "citizens" or "townsmen." In Christian Latin, gentiles (which is evidently derived from gentes) are "pagans" or "heathens" and are pictured as living in the countryside. This makes sense, considering that Christianity first formed in the cities, and rural populations remained pagan for longer. In view of the history of the meaning of civitas, Augustine's choice of this term for denoting the spiritual communities is well considered.

Of all the Latin expressions for politically organised communities, civitas appears most often in the De civitate Dei to signify the two spiritual 'states'. Occasionally, Augustine chooses societas ("society," "association") 49 as a synonym for civitas when talking about these two spiritual groups in order to call attention to their community character. ${ }^{50}$ In several instances, civitas also refers to a temporal worldly 'state'. ${ }^{51}$ This usage of the word was widespread in classical Roman literature. The related term that denotes the "citizens" is cives. 
The Roman citizens of the Classical Roman Period referred to themselves as cives from the third century $\mathrm{BC}$ onward. It must be stressed, however, that only in some instances the classical Romans spoke of civitas when their own 'state' was concerned, since civitas more often than not designated a foreign 'state' or a foreign city (even one within the Roman empire, as citizenship in classical Roman terms could also mean citizenship of a city within the Roman empire ${ }^{52}$ ). In the cases in which a foreign 'state' or city was meant, civitas was sometimes qualified by the attribute peregrina ("outlandish," "strange," "foreign")..$^{53}$ This very combination of words - civitas peregrina - also appears in the De civitate Dei; however, not with reference to a foreign worldly 'state', but with reference to the civitas Dei, ${ }^{54}$ which is not of this world. Books $\mathrm{II},{ }^{55} \mathrm{XI}^{56}$ and $\mathrm{XVI}^{57}$ of the De civitate Dei give clues as to why the author chooses civitas as the key term for the two spiritual communities. Augustine traces his usage of civitas for both spiritual 'states' back to the Latin Bible. The fact that in the De civitate Dei Augustine explicitly explains to the reader the source of his concept of civitas reveals that he is well aware of the reader's curiosity about the origin of the concept. For the present study, in which we are mainly concerned with the De civitate Dei, the answer Augustine himself provides in the text may suffice. ${ }^{58}$

It is a fact that Augustine's concept of the civitas Dei would - although it is a Christian idea - be unthinkable without reference to the pagan Roman 'state'. The Roman 'state' as a politically organised community undoubtedly served Augustine as a model when he established the concept of the civitas Dei. I believe that, when choosing a name for this concept, Augustine looked at the terms most commonly used for the Roman empire. Imperium was not a suitable term for the spiritual concept of the civitas Dei because of its military connotation. Res publica, on the other hand, was associated with the republican form of government (although its meaning might have changed slightly since the beginning of the Roman imperial period $\left.{ }^{59}\right)$. Civitas was a more suitable term, particularly because it highlighted the social, cultural and religious aspects of the politically organised community. Augustine's civitas Dei seems to draw on imperial formulations such as Constantini civitas. I believe that, at the most basic level, Augustine's model for the civitas Dei was the pagan Roman imperial idea of empire and emperor. For in the Roman imperial period, the conception prevailed that the realm and its ruler together formed an inseparable unit - and this, I think, is the underlying idea of the concept of the civitas Dei. Eusebius was the author who updated this pagan notion to a new Christian version, envisaging it fulfilled in a moral civilisation united by a permanent Christian order, and in a holy, worldwide peace, which it was the role of the ruler to create and safeguard. ${ }^{60}$

As a final point, it should be noted that the terms res publica, civitas and societas all have a wider connotation of political reciprocity (or at least rule for the common good and with a common aim), whereas regnum and imperium are entirely focused on the aspect of rulership, i.e. the fact that there is a ruler. 


\section{Dispensatio}

Dispensatio corresponds to the Greek oikovouí in its original and literal meaning of "(house) management," "stewardship," as well as in its figurative uses, of which the common nuance "divine rule" or "divine world order" - already present in the Stoic text - became most important for the Christian linguistic usage. ${ }^{61}$ Similarly, in the New Testament oikovouí may denote "priest," "priesthood," "bishop" and "episcopacy,"62 or "God's plan of salvation" (which embraces the concept of providentia) that underlies historical events. This double spectrum of meanings is transmitted to the Latin equivalents dispensator and dispensatio. ${ }^{63}$ Moreover, the use of dispensatio/oikovouí for the relationship between the persons of the Trinity had been popular since Tertullian. ${ }^{64}$ With respect to Augustine, the development of the meaning of dispensator and dispensatio is distinctive as far as both language and content are concerned; Augustine adopts the two main denotations "priest," "priesthood," "bishop" and "episcopacy," and "God's plan of salvation," but submits them to a fundamentally new interpretation. This is based (the figurative meanings borrowed from the Greek not being applicable) on the derivation of these nouns from the verb dispensare, which in its basic sense means "divide carefully," "dispense/distribute in a considered and organised manner," and "put in order." 65 Depending on the context, Augustine interprets dispensatio as "order," "arrangement/plan," "dispensation/distribution" and "donation," and explores its new definition by linking these original or literal meanings with the aforementioned conventional metaphorical meanings. ${ }^{66}$ The outcomes of Augustine's creativity are the merging of the traditionally diverging individual meanings into an integrated concept and the elimination of denotations that did not fit into this overall concept (the Trinitarian meaning is missing altogether). ${ }^{67}$ As a consequence of Augustine's strong emphasis on the verbal derivation of dispensator and dispensatio, the concept he develops is particularly dynamic, and hence often describes an act or a process rather than (according to the traditional static use of the word) a situation, property or feature. The subject performing the act of dispensare is again either God, the priest or the bishop. ${ }^{6}$ The metaphoric use of dispensator for the priest/bishop actually appears quite often in Augustine's texts. ${ }^{69}$ Augustine understands the dispensatio of a priest/ bishop as the act of a dispenser/donor. For him, the priest/bishop as the dispensator has a dual function: the preaching of the Gospel and the donation/bestowal of divine spiritual goods. Augustine subsumes this double task of the priest/bishop under the formula of dispensator verbi et sacramenti/verbum et sacramentum dispensare. ${ }^{70}$ The act of dispensare in the sense of "preaching the Gospel" or "spreading the word of God (orally or in writing)" - a use of the verb dispensare which is in fact limited to Augustine - may be performed by the dispensatores or by God himself. ${ }^{71}$ Another spectrum of meanings in Augustine's language concerns the dispensatio of God in particular. ${ }^{72}$ Augustine uses dispensatio as a term for the working of God's plans (which are unfathomable to humans) in connection with the historical economy of salvation (a use which Augustine developed in his treatises against Manichaeism) ${ }^{73}$ Here, Augustine usually interprets dispensatio 
as the "structuring/dividing" of history into the eras of the Old Testament and the New Testament or as the "attribution/assignment" of commandments or revelations to these eras. ${ }^{74}$ Thus, the word dispensatio forms part of the terminology of salvation history, which is understood as the planned revelation of God in His creation by means of variable (verbal or nonverbal) saving acts. ${ }^{75}$ Another level of meaning is created by the dispensatio of Christ. ${ }^{76}$ Here, it is to be noted that Augustine's understanding of dispensatio as a "structuring/dividing" (into Old Testament and New Testament) implies an interpretation of dispensatio as a process encompassing temporality as a whole, and is not limited to the incarnation of Christ. ${ }^{77}$ Furthermore, Augustine also uses dispensatio more generally to define any event relevant to eschatology - a thought that is in agreement with the traditional denomination of Christ's act of redemption as oikovouía. ${ }^{78}$ Nevertheless, Augustine hardly ever refers to Christ himself as the dispensator or the issuer of dispensatio. ${ }^{79}$ The only compound of dispensatio is dispensatio temporalis, which was introduced into the Latin language by Augustine. Unlike the few other uses of the verb dispensare that have God as their subject in Augustine's writing, dispensatio temporalis refers to the Christology that has yet to unfold. ${ }^{80}$ Augustine supported this Christology, which prompted his structural shaping of the theology of history, around $390 .{ }^{81}$ The compound dispensatio temporalis appears for the first time in the work De vera religione. ${ }^{82}$

\section{Felix/felicitas and beatus/beatitudo}

The concept of felix/felicitas does not feature as a lemma in the AugustinusLexikon. In "Translating Images of Authority: The Christian Roman Emperors in the Carolingian World," J. L. Nelson correctly translates felix as "happy" when drawing attention to Augustine's phrase imperatores felices. ${ }^{83}$ In Chapters 24 and 25 (on Constantine I) of Book V of the De civitate Dei, Augustine uses felix more than any other attribute to characterise the Christian Roman emperors. The term felix is well chosen. At first sight, it might seem that "happy" is not the best translation of felix: "fortunate" or "blessed" sound better in English. However, these would both be wrong for different reasons. "Fortunate" should be strictly avoided in describing Augustine's thought, since being a Christian, Augustine believed in Providence, not Fortune. This is voiced in Chapter 33 of Book IV, where Augustine claims that God is the giver of felicitas, which He distributes according to His own judgment, beyond the comprehension of human beings:

Therefore, that God himself, the producer and giver of happiness, because He alone is the true God, gives the earthly realms to both the good and the bad, and this not at random or sort of fortuitously, since He is God, not Fortuna, but according to an order of things and times obscure to us, and most known to $\operatorname{Him}[\ldots]{ }^{84}$

The adjective "blessed" can also mean "made holy." Hence, it designates "happy," but at the same time has the connotation of "being endowed with divine 
favour and protection." At first glance, this seems to be a suitable attribute of a Christian Roman emperor according to Augustine's political thought and ethics. However, those statements in the first five books of the De civitate Dei which include the term felicitas show that felicitas is used exclusively with reference to worldly happiness - and in the cases where it does allude to eternal life it is complemented by in regno caelorum, ${ }^{85}$ aeterna,${ }^{86}$ vera $^{87}$ and also plena. ${ }^{88}$ Only by these complements does felicitas become synonymous with beatitudo ("blessedness"). Augustine's various uses of felicitas are reflected in Chapter 33 of Book IV. First, Augustine declares "[...] indeed, happiness He [God] only gives to the good ones." ${ }^{99}$ Then he says, "In fact, those who serve can both not have and have, those who reign can both not have and have this [happiness], which, however, will only be complete in the life where no one will serve any more." 90 The chapter ends with "[...] true happiness." ${ }^{91}$ At least in the first five books of the De civitate Dei, which focus on the Roman secular power, Augustine is consistent in his usage of felicitas and felicitas aeterna.

It can be concluded that, by choosing these specific terms, Augustine consciously avoids any potential association of worldly rulers - including Christian Roman emperors - with divine privilege in the sense of a prospect of eternal life. The concept of felix/felicitas ("happy/happiness") thus stands in opposition to that of beatus/beatitudo ("blessed/blessedness"). Accordingly, in the first five books of the De civitate Dei, beatus/beatitudo is linked with eternal life. Some examples may serve as evidence: in Book II we read, "[...] where they may hear how they should live well here in time, in order that after this life they earn to live blessedly and forever [...]."92; later on, "Hence, if you wish to reach the blessed state, avoid the society of the demons." "93; then in Book V, "[...] which tortures are not to be despised for faith in that fatherland, to whose blessedness faith itself leads?"94

In the Latin Bible (already in the Vetus Latina), the term selected to signify "blessed" with the connotation of "being endowed with divine favour and protection" is beatus. This is expressed in the Beatitudes, in the Sermon on the Mount. Each of the Beatitudes begins with "Blessed [...]."

\section{Iustitia and pax}

In his thesis L'Augustinisme Politique, the Belgian scholar H.-X. Arquillière presented a thought-provoking theory about the development of Augustine's political ideas from Late Antiquity to the Middle Ages. Arquillière's theory is discussed and strongly supported by Dvornik. ${ }^{96}$ Arquillière was aware of Augustine's dilemma as manifested in the De civitate Dei. He rightly maintained, contrary to Bernheim, that Augustine does attribute a legitimate power, in conformity with God's providential plan, even to the ancient pagan realms before the emergence of Christianity. Thus, according to Arquillière, Augustine also pleads (in line with St. Paul and the patristic tradition) for obedience on the part of the people to any ruler - unless the ruler's will is against Christian moral principles. ${ }^{97}$ Dvornik believes that some scholars, including Bernheim, assume that Augustine considers the good deeds of the citizens of the civitas Dei alone to be legitimate 
virtues. While Dvornik admits that for Augustine the legitimate virtues, which grant men eternal salvation, are the deeds done by members of the civitas Dei (who have true faith in God), he emphasises that Augustine at the same time also accepts the existence of natural virtues, which, for instance, prevailed among the heathen Romans and helped them to expand and protect their 'state' ${ }^{98}$ In the Augustinus-Lexikon s.v. iustitia, the theologian R. Dodaro makes a similar argument. ${ }^{99}$ Dodaro reasons that in some letters to public officials and authorities engaged in secular pursuits (e.g. Augustine's epist. 48 ad Vincentium, quoted by Hincmar of Rheims in his De regis persona et regio ministerio), Augustine outlines an argument concerning the transformation of the four virtutes civiles (sapientia/prudentia, temperantia, fortitudo/magnitudo animi and iustitia) beyond the fundamental level of virtue attained by pagan politicians who lack vera pietas (which consists of the knowledge and love of the true God). By allowing their conception of iustitia to be transformed by fides, spes and caritas, Christian politicians will, according to Augustine, fight wars in a more virtuous manner than that which is sustained by the Roman concept of bellum iustum, ${ }^{100}$ and they will punish offenders with iustitia tempered with misericordia. ${ }^{101}$ Unlike Bernheim, Arquillière, Dvornik and Dodaro seem to acknowledge the natural dimension of the concepts of iustitia and pax. Both concepts permeate the De civitate Dei and have the purpose of establishing true order in human society. ${ }^{102}$ They function in like manner in the civitas Dei as in the civitas terrena. In simple terms, their double meaning - i.e. their natural vs. divine sense - can be defined as follows: the natural form of iustitia or pax $x^{103}$ is the iustitia or pax given by men to men; the divine form of iustitia ${ }^{104}$ or pax ${ }^{105}$ is the iustitia and pax given by God to men. As soon as the concepts of iustitia and pax are spiritualised, they are determined by the Gospel's main law of love of God and of one's neighbour. Arquillière stated that Bernheim indeed saw correctly the importance of the Augustinian concepts of iustitia and pax in later, medieval political thought. However, Bernheim seemed not to have realised that for Augustine their natural, worldly forms likewise have a substantial value for life on earth. ${ }^{106}$

Arquillière claimed that the devaluation of the natural forms of these goods started in Merovingian times when kingship began to be seen in a subordinate relationship to the 'church'. Accordingly, earlier medieval thinkers, such as Gregory the Great and Isidore, and later Smaragdus of Saint-Mihiel and Jonas of Orléans, retained from Augustine merely the extreme statements that devalued the earthly 'state' (above all the Roman 'state'). Dvornik notes that in Isidore's texts from the late seventh century, the idea of the 'state' based on natural law had almost disappeared. He reasons that Isidore regards the 'state' as necessary only for the defence and protection of the 'church'. ${ }^{107}$ Arquillière termed this shift in focus, away from the recognition of the natural law of the 'state', Augustinisme politique. ${ }^{108}$ What is most striking is that Arquillière saw exceptional circumstances under Charlemagne's reign; he argued that under Charlemagne, Catholicism did not exist as a separate entity because of the merging of political and religious affairs. ${ }^{109}$ While Augustine had separated Catholicism from political affairs, Augustinisme politique did not. Dvornik, for his part, notes that the theory of 
Augustinisme politique was integrated into the coronation rituals of the medieval Frankish kings. He maintains that kings were still seen as elected by God, not on the grounds of natural law as the emperors in Christian Hellenism, but through the 'church' as a mediator. Thus, it occurred that, by the end of the eighth century, the notion of natural law was superseded by that of the divine law, and the purpose of the 'state' was believed to lie solely in the service of the 'church'. ${ }^{110}$ At the time of Charlemagne, iustitia and pax were wholly safeguarded by the omnipotent emperor. ${ }^{111}$ The political and religious domains were successfully dominated by Charlemagne. Hence, he was the one medieval emperor who, by taking on the task of implementing iustitia and pax, could give to these concepts the religious meanings they had adopted since Merovingian times under the influence of Augustinisme politique. ${ }^{112}$

The foregoing analysis of Augustine's understanding of worldly rule and rulership and his definitions of politically organised communities has revealed that in the De civitate Dei, Augustine evidently praises the Christian Roman emperors. His praise is primarily aimed at two Christian rulers who have successfully promoted Christianity and have supported the Christian 'church', namely emperors Constantine I and Theodosius I. However, it has turned out that Augustine's praise is not general, but is rather particular, since it focuses on specific achievements and deeds for which there is conclusive evidence. Moreover, Augustine chooses a formulation that gives the reader scope for deciding on how to judge worldly Christian rulership: "[...] the reward for which deeds is eternal happiness, whose giver is God to the truly pious alone." ${ }^{113}$ Nowhere in the De civitate Dei does Augustine clearly state that in his opinion a particular secular leader will be rewarded with eternal happiness. This is expressive of the unfolding tension in the work between an approval of the supreme worldly power of Christian (and to some extent pagan) rulers and a harsh criticism of any form of worldly social organisation, government and power.

In philosophical, conceptual and linguistic terms, an intellectual development from a Greco-Roman to a Judaeo-Christian perspective via neo-Platonism and St. Paul can be observed. An important strand of the philosophical tradition comes via Cicero. It is first and foremost Cicero's sceptical stance, his manner of considering supporting and opposing arguments, that is reflected in Augustine's discourse and reasoning on divine and earthly rule. Cicero, on the one hand, by enhancing Polybius' argument and claiming that the key element in the Romans' rise to power has been from the beginning the wisdom and moral superiority of individuals, sets the basis for Roman political thinking. Augustine, on the other hand, by providing an alternative definition of "state" based on divine law alongside that suggested by Cicero based on natural law, lays the foundation for a versatile application of his brand of political thought and ethics in Christian considerations of the 'state' in later periods.

Augustinian political thought and ethics, as based on the Old Testament, Biblical tradition, as well as the aforementioned philosophical tradition, will prove to be reflected in Christian Carolingian political thought. Its versatile application in Christian political reflections will be illustrated in the arguments 
made by two eminent Carolingian advisers to the rulers of the first and third generation: Charlemagne and Charles the Bald. Augustine's De civitate Dei was, according to Einhard's account in the Vita Karoli Magni, Charlemagne's favourite text. ${ }^{114}$ Having examined Augustine's treatise in detail, and having exposed the terminological problems and ambiguities that arise in Augustine's conception of different types of politically organised communities, it remains to be seen how the political advisers Alcuin of York and Hincmar of Rheims understood the work's message. What will emerge, among other things, is that Alcuin's and Hincmar's different views of Augustinianism are expressed particularly well in their ideas and political discourse on the Roman emperors (e.g. Constantine I and Theodosius I) and the Old Testament kings (e.g. David and Solomon).

\section{Notes}

1 By 'Augustinian', I refer to the thought that is manifested in Augustine's later work in particular the De civitate Dei.

2 According to Arendt, as a general rule, Augustine availed himself of amor to designate desire and craving (that is love in its largest, least specific sense), dilectio to designate the love of self and neighbour, and caritas to designate the love of God and the "highest good." As an example of Augustine's terminological inconsistency, Arendt mentioned that Augustine also distinguished occasionally between licit and illicit caritas. Arendt 1996, pp. 38-39. The Augustinus-Lexikon has articles on amor, dilectio and caritas by Dideberg. In accordance with Arendt, Dideberg established that Augustine used all three words in order to denote a concept, which, in the most general sense, translates as "love." As far as the term amor is concerned, Dideberg's argument corresponds to that of Arendt, who claimed that for Augustine amor had a wider and more indefinite sense than dilectio and caritas. With regard to dilectio and caritas, however, Dideberg found little to distinguish their use in Augustine. AL vol. 1 1986-1994, pp. 294-300, 730-743, vol. 2 1996-2002, pp. 435-453.

3 OLD vol. 2 1976, pp. 1600-1601, 1650-1651.

4 Civ. IV, V, XVIII, XX.

5 As a result, translations of regnum into modern languages often also have both connotations (e.g. "kingdom" as a political unit and "Kingdom" as a spiritual unit).

6 Civ. IV 3, p. 150, IV 6, p. 153, V 21, p. 233, V 25, p. 238, XIV 1, p. 3, XIV 7, p. 15, XV 8, p. 72, XVIII 3, p. 260, XVIII 6, p. 263, XVIII 15, p. 274, XX 23, pp. 464, 465.

7 See also Martin 1972, pp. 195, 203-206. Martin argues that Augustine, in Chapter 4 of Book IV of the De civitate Dei, equates regna with imperia. According to Martin, regna and imperia both have certain features in common with latrocinia ("bands of robbers"). Thus, the general theme of Chapter 4 of Book IV is the nature of "imperial states" as a whole. The similarity of all "imperial states" lies "[...] in their motivation by love of domination and their imposition of rule by war and force [...]" Ibid., p. 203. My interpretation of Augustine's use of regnum in the sense of "world power" and "empire" governed by imperatores and dominant over other 'states' is in line with this argument.

8 Civ. I 36, p. 52, IV 2, p. 148.

9 This is a Biblical phrase often used by Augustine. Civ. V 24, p. 237, XIV 2, p. 5 , XVIII 31, p. 298, XX 4, p. 411, XX 9, p. 428.

10 Civ. XVIII 20, p. 281.

11 Civ. XX 9, pp. 429, 430, 431, XX 13, p. 437.

12 Civ. V 12, p. 212. 
13 OLD vol. 1 1968, pp. 843-845; TLL Online 1900-, Lemma/Sublemma, s.v. imperium, $-\bar{\imath} n$.

14 Civ. I, IV, V.

15 Civ. II 29, p. 96.

16 His ego nec metas rerum nec tempora pono;

Imperium sine fine dedi. Aen. 1.278f. Another significant passage on imperium in the Aeneid is Aen. 8.714-8.731.

$17[\ldots]$ nec metas rerum nec tempora ponit, Imperium sine fine dabit. Civ. II 29, p. 96, 11. 7-8.

18 Civ. I 30, p. 47, I 36, p. 52, II 17, p. 73, II 20, p. 79, IV 2, p. 148, IV 5, p. 151, V 1, p. 190, V 18, pp. 227, 228, XX 19, p. 450.

19 Civ. IV 6, p. 152, XVIII 21, p. 283, XIX 7, p. 366, XIX 24, p. 400.

20 Civ. I 36, p. 52, IV 2, p. 147, IV 7, p. 153, IV 15, p. 165, IV 29, p. 182, V 12, pp. 211, 214-216, V 15, p. 220, XII 3, p. 515.

21 Civ. I 23, p. 38, I 26, p. 41, IV 26, p. 178, V 18, p. 224, XII 26, p. 553.

22 Another derivative of imperare, imperator, which in the Classical Roman Period signified "commander," "commander-in-chief," "(victorious) general" (as a title of honour) and "emperor." even more strongly expresses its relatedness to military affairs. OLD vol. 1 1968, pp. 842-843; TLL Online 1900-, Lemma/Sublemma, s.v. imperātor, -ōris m. See Combès 1966 for further reading on the formation of the term imperator during the Roman Republic.

23 OLD vol. 2 1976, pp. 1635-1636. Schofield's translations of the term res publica do not include the English word "state." Instead, he suggests "public-spirited activity," "public affairs/business," "the public interest", "the community sc. as the prime locus of public activity/the prime beneficiary of the public interest," "the community constituted by the civitas or populus" and "the country." Schofield 1999, p. 180. Schofield reflects Skinner's proposition that "so long as the powers of the community, if exercised by a prince or a magistrate, are regarded on Ciceronian principles as simply entrusted to him, there is no logical space for the idea of a state or commonwealth distinct from the people or the community. But where it is held ... that political powers involve a transfer ('translatio') of the people's sovereignty - not so much delegation as alienation - a logical gap opens up between the powers of a community of citizens and those of a distinct impersonal authority, even if vested in a prince or magistrate, which is now in the sense indicated absolute." Ibid., p. 181. However, I do not think that all of Schofield's alternatives necessarily imply less alienation than delegation - certainly not the renderings "public affairs/business" or "the country."

24 Civ. I, II, V, XIX.

25 Civ. II 11, p. 65.

26 Civ. II 18, p. 74.

27 Ibid., p. 75.

28 Civ. V 18, p. 227.

29 Civ. V 24, pp. 236, 237.

30 Civ. I 15, p. 25, II 18, p. 75, IV 2, p. 147, V 12, p. 212, XV 5, p. 64, XIX 21, p. 389.

31 Civ. II 19, p. 77, II 21, p. 83.

32 ... res publica, cuius conditor rectorque Christus est, si et ipsam rem publicam placet dicere, quoniam eam rem populi esse negare non possumus. Si autem hoc nomen, quod alibi aliterque vulgatum est, ab usu nostrae locutionis est forte remotius, in ea certe civitate est vera iustitia .... Civ. II 21, p. 83, 11. 9-14.

33 Schofield 1999, p. 183.

34 Civ. XIX 24, p. 400.

35 K1P vol. 4 1972, pp. 1381-1384.

36 In looking for possible translations of the Latin word civitas, Oort's main argument is that "state," although often used by earlier German and Dutch scholars to render Augustine's concept of civitas, is not a suitable term because Augustine does 
not offer a detailed political theory. Oort van 2013, pp. 102-108. Oort's claim that civitas translated as the English "state," or German/Dutch "Staat"/"staat," has too strong a political connotation, is only partly correct - it may apply to the English "state" but not to the German word "Staat" as it is presently used. Ibid., pp. 104105. Although quoting in the original language is a laudable practice, it must be noted that Oort's references to and quotations from German scholarship are often outdated, which is perceptible in the language of the quotations themselves. Above all, however, Oort's reference to German scholarship in order to support his main claim that both the English "state" and the German "Staat" are not appropriate translations - i.e. Scholz 1911 [sic] - is no longer valid. Ibid., pp. 104-105 (note 472). Scholz refers to the "Klangfarbe" of the German word "Staat" as it was used over a hundred years ago. His judgment is no longer defensible, since the connotations of the German word "Staat" have slightly changed. The German word "Staat" is a very broad term today with a wide range of meanings. See Max Weber's "Staatsbegriff," discussed in Pohl 2006, pp. 9-10. The general definition provided by DUDEN 2012 shows that the word "Staat" does not necessarily need to be linked to the political sphere. "Staat" is defined as "Gesamtheit der Institutionen, deren Zusammenwirken das dauerhafte und geordnete Zusammenleben der in einem bestimmten abgegrenzten Territorium lebenden Menschen gewährleisten soll." DUDEN 2012, s.v. Staat. (Such words as "Bienenstaat" are also expressive of the broad spectrum of meanings the German term "Staat" covers.) The fact that Oort quotes in the original languages (e.g. English and German/Dutch) and hence uses words from different languages as translations of the Latin term civitas clouds the matter: Oort presumes that the connotations of the English "state" and German "Staat" are identical. See Airlie, Pohl and Reimitz 2006, Vorwort. The compound civitas Dei itself makes it clear that this civitas belongs first and foremost to the Christian God, who is its leader. English "states" (or German "Staaten") do have a leadership. In the possible English translation "city" (or German "Stadt") for civitas, the leadership is not as readily implied, nor would "mayor" be an appropriate equivalent to the Christian God whom Augustine presents as the leader of the civitas Dei. See also Oort van 2013, p. 106. Even in terms of the size of Augustine's spiritual communities (civitas Dei and civitas terrena), the English "state" (or the German "Staat") would be a more realistic translation. Neither is Oort's reason for insisting on the two "cities" of Jerusalem and Babylon as the best representatives of the civitas terrena and civitas Dei on earth entirely plausible. On p. 105, Oort maintains: "A strong argument for the choice of 'city' is the fact that, when writing about the origin and nature of the civitas Dei, Augustine makes special reference to biblical passages pertaining to Jerusalem. The same applies for the designation of the terrena civitas as a city: Babylon." This claim is supported only by few references. What is more, a conflicting statement can be found on p. 71, where Oort refers to relevant passages in Book XVIII of the De civitate Dei. He writes about Book XVIII: "First the author outlines the development of the terrena civitas since Abraham, so that the readers can compare the two cities. He gives an overall view of world history, always chronologically related to that of Israel: Assyria (= Babylonia prima), Egypt, Greece and the rise of the Roman Empire (Roma quasi secunda Babylonia)." In the De civitate Dei, Israel and pagan Assyria or Babylonia appear with at least the same frequency next to the cities of Jerusalem and Babylon. A word search on the eMGH showed 98 hits for Israel, 66 hits for the 'city' of Hierusalem, 22 hits for Babylonia and Assyria together and 21 hits for the 'city' of Babylon in the De civitate Dei. It must be acknowledged that, when drawing analogies from the spiritual to the temporal sphere, Augustine generally relates the civitas terrena and the civitas Dei to systems and communities that are larger than a 'city'. The philosopher Martin bases his analysis of Augustine's political philosophy on the claim that Augustine does not identify either of the two civitates with earthly institutions. However, he argues that some institutions represent these civitates in 
history: the "imperial states" collectively embody the civitas terrena and the institutional 'church' (since Christ) does the work of the civitas Dei. Martin 1972, p. 203. On these grounds, Martin retains the notion of a Christianised 'state' as a possible interpretation of Augustine and writes that "it is possible that the church might appropriate some sort of political apparatus for its own purposes just as the Hebrew nation had generated a state, the Hebrew Kingdom." Ibid., p. 204. It is clear that in Martin's study likewise, both bodies, the civitas terrena and the civitas Dei, are intrinsically associated with systems and communities that resemble 'states'. Last but not least, the only reason Augustine refers to the 'city' of Babylon and the pagan Assyrian 'state' more frequently than to the 'city' of Rome and the pagan Roman 'state' when talking about the origins of the civitas terrena, is because Babylon and Assyria form the "pre-image" (typos) and existed first. After all, in Chapter 1 of Book XI, Augustine relates his use of civitas back to the (Latin) Bible. But is the 'city' of Babylon or the pagan Assyrian 'state' really given more weight than Rome or the pagan Roman 'state' in the De civitate Dei? Noteworthy passages prove otherwise: in the De civitate Dei, the pagan Assyrian and Roman 'states' are presented as the two Eastern and Western 'states' that succeed and replace each other - the former relevant to the Old Testament, the latter relevant to the New Testament. My argument is that in the De civitate Dei it is rather the Roman 'state' that is given more relevance (Civ. V 13, p. 217, XVIII 22, p. 284.). In Chapter 2 of Book XVIII, Augustine explains that his portrayal of the civitas terrena as paralleling the civitas Dei will, due to the density of available source material, focus in the first instance on the Roman 'state' (Civ. XVIII 2, p. 258.). Compared to the Assyrians, Augustine sees the Romans as more competent and efficient in political organisation and the military subjection of other races. It is said that the Romans had to overcome much more dangerous enemies who were more capable in their defence than the enemies of the Assyrians had been (Civ. XVIII 22, p. 284.). On the general use of the English word "state" for Latin terminology relating to different types of politically organised communities, see my argument in the Introduction under 'State-Church' Relatios in Late Antiquity and the Early Middle Ages.

37 OLD vol. 1 1968, p. 330; TLL Online 1900-, Lemma/Sublemma, s.v. cìvitās, -ātis f; ; Flasch 2003, p. 385. On the most common meanings of the word civitas, see also Oort van 2013, p. 102.

38 Civ. I 15, p. 27, 11. 3-4. See also Oort van 2013, p. 107.

39 Civ. XV 8, p. 73, 11. 27-29. See also Oort van 2013, p. 103; Markus 1970, pp. 61-62.

40 Flasch 2003, p. 385; Procopé 1988, p. 21. Boler finds that the image of the two civitates appeals to the polis. Boler 1978, p. 83. Oort strongly supports this thesis. Oort van 2013, pp. 103-105, 107-108. He notes that even Cicero translated polis as civitas. Ibid., p. 107 (note 483). However, his argument concerning the correct interpretation of civitas is ambiguous. On p. 104, Oort maintains that "if a definitive choice must be made for a 'translation' of the comprehensive concept civitas, the best approximation would be polis," and on p. 107 restates that, "for Augustine, as for others, it civitas is an equivalent of the Greek concept polis." On pp. 103-104, he draws attention to the important fact that polis, although often rendered as "city-state," "encompasses much more than we can indicate with this word combination, namely the entire communal life of a group of people, including their politics, culture, ethics and economics. And a polis certainly need not be a city with one centre ... even regions could be denoted by this name." Nevertheless, on p. 105 Oort somewhat inexplicably arrives at the conclusion that "the use of the word city is, in my opinion, the best way to denote the meaning of civitas."

41 Morrison 1985, p. 8.

42 Flasch 2003, p. 385. Oort confirms the meaning of both the polis and the civitas as "cult communities." Oort van 2013, pp. 104, 107-108. He writes: "It is especially 
significant in this context that every polis had its own particular cult: religion and polis, polis and religion were inextricably bound up with each other. The civitas was even the central object of the Roman religion. ... To see the extent to which civitas could be an explicitly religious concept for the Romans, one has only to look at various epithets found in non-Christian classical writings." Oort adds that "... in Augustine's description of civitas Dei and terrena civitas the unity of culture, custom and especially religion has a prominent role." Ibid., p. 104.

43 Civ. XIV 28, p. 56.

44 Oort van 2013, p. 107.

45 Schofield provides evidence that in several instances in the De re publica, the term civitas functions as a synonym of res publica, which is arguably reminiscent of the Greek polis. Schofield 1999, p. 182.

46 See also Oort van 2013, pp. 107-108.

47 AL vol. 3 2004-2010, pp. 140-141.

48 Ibid., p. 140.

49 KIP vol. 5 1975, p. 245.

50 Civ. V 15, p. 220, XII 1, p. 512, XII 9, p. 525, XII 28, p. 556; see also Flasch 2003, p. 385; Markus 1970, pp. 61-62; Oort van 2013, p. 103. Baynes already wrote that “... students are now, it would seem, agreed ... that civitas is best rendered by some such word as 'society' ...." Baynes 1936, p. 5. Oort also draws attention to the community character and the personalistic element in both civitas and the ancient polis. Oort van 2013, p. 107.

51 Civ. I 31, p. 48, II 9, p. 63, II 11, p. 65, IV 31, p. 185, XIX 24, p. 400. Oort, by contrast, writes: "Only rarely does he Augustine use the word civitas to indicate the state as we know it today." However, Oort's claim is not supported by evidence. Oort van 2013, p. 104.

52 Those living in the Roman empire who had no Roman citizenship first acquired the citizenship of a particular Roman city before gaining the Roman citizenship.

53 By far the most common expression in classical Latin for the Roman 'state' is populus Romanus. KlP vol. 1 1964, pp. 1198-1199.

54 Civ. I 35, p. 51, XVIII 1, p. 255, XVIII 2, p. 258.

55 Civ. II 21, p. 83, 11. 13-15.

56 Civ. XI 1, pp. 461-462. A more detailed treatment of Book XI of the De civitate Dei can be found under Alcuin's Use of Augustinian Vocabulary in Alcuin's Indirect Use of Augustine: His Stance on Worldly Rule and Recourse to Augustine's Terminology, the second chapter of Part II.

57 Civ. XVI 4, pp. 129-131, XVI 10, pp. 139-141, XVI 11, pp. 142-145.

58 Oort, however, gives a comprehensive account of the most frequently discussed elements of influence on Augustine's doctrine of the two civitates with particular focus on the Donatist theologian Tyconius and on Manichaean thought. Oort van 2013, pp. 8ff., 108-115, 274f. The earlier scholar Baynes also gives prominence to the influence of Tyconius' commentary on the Apocalypse. He writes: "The conception of the two 'cities' comes ultimately from the Bible: Jerusalem, the holy city, is contrasted with Babylon: but, more directly, modern research has tended to show, Augustine derived his theme from Ticonius, the Donatist, who in his work on the Apocalypse had interpreted the Book of Revelation on similar lines." Baynes 1936, p. 5.

59 Cf. the debated notion of res publica restituta under Augustus.

60 Campenhausen von 1963, p. 65; Young 2010, p. 651; Garnsey 2010, p. 411.

61 AL vol. 2 1996-2002, p. 487.

62 It must be noted that debate surrounds the existence of these roles, in their later sense, in the New Testament.

63 AL vol. 2 1996-2002, p. 487.

64 Ibid., p. 488. 
65 Ibid.

66 Ibid.

67 Ibid.

68 Ibid.

69 Ibid., p. 489.

70 Ibid.

71 Ibid., p. 490.

72 Ibid.

73 Ibid.

74 Ibid.

75 Ibid. Here I refer to Markus' discussion of the concepts of "salvation history," "sacred history" and "secular history" without, however, going as far as adopting his terminology in my research. Markus 1970, pp. 9-21, 231-232. Despite his awareness on p. 72 that the method of "... reading back into Augustine" is in principle impermissible, as this may result in anachronism, Markus' aim in the discussion of these concepts is "... to render explicit and precise what is implicit in Augustine's view." Ibid., p. 231. His argument is based on Augustine's term "sacred history" (historia sacra), which is drawn from Chapter 8 of Book XV of the De civitate Dei, where it refers to the Christian Scriptures. Ibid., p. 9 (note 5). Markus uses this term to discriminate between the Biblical narratives and "secular," historical narratives, while admitting that "... the expression 'secular history' does not form part of his Augustine's vocabulary." Ibid., p. 9. His reasoning is that, according to Augustine, "sacred history" was infused with a special character derived from the Biblical authors' prophetic insight into the events recorded by them. Ibid., pp. 14-15. Markus writes: "The difference between 'sacred' and 'secular' history is therefore to be defined by distinguishing between two different kinds of narrative: the one prophetically inspired, the other not." Ibid. According to Markus, Augustine made a distinction between two types of "history": i.e. "history" as a series of past events and "history" as a record of past events. Markus holds that in Augustine's conception of "sacred history" (historia sacra), "history" is always seen as a record, since in "history" as a series of past events "... there is nothing distinctive about any part of history in virtue of which some history is 'sacred' ..." Ibid., p. 231. Thus, Markus argues, "his Augustine's distinction between 'sacred' and 'secular' history only makes sense if 'history' is understood ... as statements about the past, recording events." Ibid., p. 14. Markus criticises Cullmann's notion of "salvation history" (Heilsgeschichte) because it merely seems to refer to "... what has happened ...," and does not presuppose any distinction between "history" as events and "history" as record on Augustine's part. Ibid., pp. 231-232. Cullmann's view appears to be in line with the terminology provided in the Augustinus-Lexikon. In my research, I use "salvation history" without suggesting that Augustine's conception presupposed a distinction between the two senses of "history." The main reason is that the distinction Markus makes is entirely based on a conceptual division of "sacred history" and "secular history," which was never explicitly expressed by Augustine. In the work Saeculum, Markus is consistent in his use of the concepts of "sacred history" and "secular history." However, the difference in meaning between the terms "sacred history," "salvation history"/ "history of salvation" and Heilsgeschichte/heilsgeschic htlich is not entirely clear. These English and German terms are used indiscriminately on pp. $44,47,54,55$.

76 AL vol. 2 1996-2002, p. 490.

77 Ibid., pp. 490-491.

78 Ibid., p. 491.

79 Ibid.

80 Ibid.

81 Ibid. 
82 Ibid., pp. 491-492.

83 Nelson 1996, p. 89.

84 Deus igitur ille felicitatis auctor et dator, quia solus est verus Deus, ipse dat regna terrena et bonis et malis, neque hoc temere et quasi fortuito, quia Deus est, non fortuna, sed pro rerum ordine ac temporum occulto nobis, notissimo sibi [...]. Civ. IV 33, p. 188, 11. 6-10.

85 Civ. V 21, p. 232.

86 Civ. V 24, pp. 236-237.

87 Civ. IV 3, p. 150.

88 Civ. IV 33, p. 188.

89 [...] felicitatem vero non dat nisi bonis. Ibid., p. 188, 1. 12.

90 Hanc enim possunt et non habere et habere servientes, possunt et non habere et habere regnantes; quae tamen plena in ea vita erit, ubi nemo iam serviet. Ibid., p. 188, 11. $13-15$.

91 [...] vera felicitas. Ibid., p. 188, 11. 23-24.

$92[\ldots]$ ubi audiant quam bene hic ad tempus vivere debeant, ut post hanc vitam beate semperque vivere mereantur [...]. Civ. II 28, p. 94, 1. 31-p. 95, 1. 1.

93 Proinde si ad beatam pervenire desideras civitatem, devita daemonum societatem. Civ. II 29, p. 97, 11. 4-5.

$94[\ldots]$ qui cruciatus non sunt pro fide illius patriae contemnendi, ad cuius beatitudinem fides ipsa perducit? Civ. V 18, p. 226, 11. 25-27.

95 Beati [...]. Mt 5:3-12.

96 Dvornik 1966, p. 849.

97 Ibid., p. 841; Chadwick 1988, pp. 12-13. On the Carolingians, see the discussions in Wallace-Hadrill 1971, pp. 127-128; Wallace-Hadrill 1975, pp. 193-195.

98 Dvornik 1966, pp. 846-847.

99 AL vol. 3 2004-2010, p. 879.

100 On this concept, see Markus 1988, pp. 115-116; Wiedemann 2010, p. 524.

101 AL vol. 3 2004-2010, p. 879.

102 On Augustine's concept of iustitia in the De civitate Dei, see also Dodaro 1999, pp. 181-183; Markus 1970, pp. 64f., 99f., 208; Wilks 1967, pp. 496-499; Baynes 1936, pp. 16-17. The concept of pax is discussed by Schofield 2010, pp. 667-671; Martin 1972, p. 214ff.; Markus 1970, pp. 68f., 83f., 95f.

103 Dvornik defines the natural pax as "natural mutual accord" in human society. Dvornik 1966, p. 846.

104 Arquillière states that Augustine's divine iustitia corresponds to St. Paul's evangelical justice. However, he claims that Augustine was the first to apply it to the constitution of 'states'. Arquillière 1934, p. 21.

105 Dvornik's translation of Augustine's definition of divine pax in Chapter 13 of Book XIX of the De civitate Dei is: "The peace of the heavenly city is a perfectly ordered and fully concordant fellowship in the enjoyment of God and in mutual enjoyment by union with God; the peace of all things is a tranquillity of order." Dvornik 1966, p. 845 .

106 Arquillière 1934, pp. 151f.

107 Dvornik 1966, p. 848.

108 Arquillière 1934, p. 152.

109 His argument is supported by Wallace-Hadrill 1971, p. 103; Wallace-Hadrill 1975, pp. 189, 193.

110 Dvornik 1966, pp. 848-849.

111 Arquillière 1934, p. 128.

112 Ibid., p. 131.

113 Civ. V 26, p. 240, 11. 26-27.

114 V.Kar. 24, p. 29. 


\section{Bibliography}

\section{Primary sources}

Augustinus Hipponensis: Sancti Aurelii Augustini episcopi De civitate Dei libri XXll 2 vols. Bernhard Dombart et Alfons Kalb (recogn.). (5th ed.). Stuttgart, 1993.

Einhardus: Vita Karoli Magni. Post G. H. Pertz recensuit G. Waitz. Editio sexta. Oswald Holder-Egger (ed.) (MGH SS rer. Germ. 25). Hannover, 1911.

Publius Vergilius Maro: Aeneis. Gian Biagio Conte (recensuit atque apparatu critico instruxit). Berlin, 2009.

\section{Secondary sources}

Airlie, Stuart, et al. (eds.): Staat im frühen Mittelalter. Wien, 2006.

Arendt, Hannah: Love and Saint Augustine. Edited and with an interpretive essay by Joanna Vecchiarelli Scott and Judith Chelius Stark. Chicago, 1996.

Arquillière, H.-X.: L'Augustinisme politique: Essai sur la formation des théories politiques du Moyen-Âge. Paris, 1934.

Baynes, Norman Hepburn: The Political Ideas of St. Augustine's De civitate Dei. Historical Association Pamphlet 104, 1936, 3-18.

Boler, John: Augustine and Political Theory. Mediaevalia: A Journal of Medival Studies 4, 1978, 83-97.

Campenhausen von, Hans: The Fathers of the Greek Church. Revised transl. from the German by L. A. Garrard. London, 1963.

Chadwick, Henry: Christian Doctrine, in: James Henderson Burns (ed.): The Cambridge History of Medieval Political Thought c. 350-c. 1450. Cambridge, 1988, 11-20.

Combès, Robert: Imperator: Recherches sur l'emploi et la signification du titre d'imperator dans la Rome républicaine. Paris, 1966.

Dodaro, Robert: Church and State, in: Allan Fitzgerald (ed.): Augustine Through the Ages: An Encyclopedia. Grand Rapids, MI, 1999, 176-184.

Dvornik, François: Early Christian and Byzantine Political Philosophy: Origins and Background 2 vols. Washington, D. C., 1966.

Flasch, Kurt: Augustin: Einführung in sein Denken. (3rd, supplemented ed.). Stuttgart, 2003.

Garnsey, Peter: Introduction: The Hellenistic and Roman Periods, in: Christopher Rowe and Malcolm Schofield (eds.): The Cambridge History of Greek and Roman Political Thought. (5th printing). Cambridge, 2010, 401-414.

Markus, Robert Austin: Saeculum: History and Society in the Theology of St Augustine. Cambridge, 1970.

Markus, Robert Austin: The Latin Fathers, in: James Henderson Burns (ed.): The Cambridge History of Medieval Political Thought c. 350-c. 1450. Cambridge, 1988, 92-122.

Martin, Rex: The Two Cities in Augustine's Political Philosophy. Journal of the History of Ideas 33, 1972, 195-216.

Morrison, Karl Frederick: Holiness and Politics in Early Medieval Thought. London, 1985.

Nelson, Janet Laughland: Translating Images of Authority: The Christian Roman Emperors in the Carolingian World, in: Janet Laughland Nelson (ed.): The Frankish World, 750900. London and Rio Grande, 1996, 89-98.

Oort van, Johannes: Jerusalem and Babylon: A Study into Augustine's City of God and the Sources of His Doctrine of the Two Cities. (Repr. of the 1st ed. 1991). Leiden, 2013. 
Pohl, Walter: Staat und Herrschaft im Frühmittelalter: Überlegungen zum Forschungsstand, in: Stuart Airlie et al. (eds.): Staat im frühen Mittelalter. Wien, 2006, 9-38.

Procopé, John: Greek and Roman Political Theory, in: James Henderson Burns (ed.): The Cambridge History of Medieval Political Thought c. 350-c. 1450. Cambridge, 1988, 21-36.

Schofield, Malcolm: Saving the City: Philosopher-Kings and Other Classical Paradigms. London, 1999.

Schofield, Malcolm: Epilogue, in: Christopher Rowe and Malcolm Schofield (eds.): The Cambridge History of Greek and Roman Political Thought. (5th printing). Cambridge, 2010, 661-671.

Wallace-Hadrill, John Michael: Early Germanic Kingship in England and on the Continent: The Ford Lectures Delivered in the University of Oxford in Hilary Term 1970. Oxford, 1971.

Wallace-Hadrill, John Michael: The Via Regia of the Carolingian Age, in: Idem (ed.): Early Medieval History. Oxford, 1975, 181-200 (first published Oxford 1965, 22-41).

Wiedemann, Thomas: Reflections of Roman Political Thought in Latin Historical Writing, in: Christopher Rowe and Malcolm Schofield (eds.): The Cambridge History of Greek and Roman Political Thought. (5th printing). Cambridge, 2010, 517-531.

Wilks, Michael John: Roman Empire and Christian State in the De civitate Dei. Augustinus 12, 1967, 489-510.

Young, Frances: Christianity in: Christopher Rowe and Malcolm Schofield (eds.): The Cambridge History of Greek and Roman Political Thought. (5th printing). Cambridge, 2010, 635-660.

\section{Dictionaries and lexica}

Dudenredaktion (eds.): DUDEN: Das grosse Wörterbuch der deutschen Sprache. (4th completely revised ed.). Mannheim, 2012.

Mayer, Cornelius Petrus, Feldmann, Erich and Chelius, Karl Heinz (eds.): AugustinusLexikon vols. 1-4, Doppelfasz. 5/6. Basel, 1986-2017.

Thesaurus Linguae Latinae Online. München, 1900.

Ziegler, Konrat and Sontheimer, Walther (eds.): Der Kleine Pauly: Lexikon der Antike in fünf Bänden 5 vols. München, 1964-1975. 
$\Longrightarrow$ Taylor \& Francis Taylor \& Francis Group http://taylorandfrancis.com 
Part II

Alcuin of York 
$\Longrightarrow$ Taylor \& Francis Taylor \& Francis Group http://taylorandfrancis.com 


\section{Alcuin's direct use of Augustine in the 'Epistolae'}

This second part explores the influence of Augustine of Hippo on Alcuin of York's writing. ${ }^{1}$ The intention is to examine different aspects of Augustine's influence on Alcuin's surviving body of work, with a strong focus on Alcuin's political ideas. His Epistolae provides the basis for this analysis. Alcuin's correspondence deserves attention because the letters he wrote - to Charlemagne, his children and his closest friends (e.g. Arn, Bishop of Salzburg, and Angilbert, Abbot of Saint-Riquier) - not only reveal the nature of Alcuin's political thought, but also the manner in which he communicated to his peers the thoughts he considered important for strengthening the rule of the Carolingians. The epistles show more clearly than any of his treatises the way in which Alcuin attempted to put his political agenda into effect. ${ }^{2}$

Finding direct influence from Augustine in the sources is challenging, because it is not always possible, on the basis of references to Augustine, to ascertain whether Alcuin was quoting from Augustine directly or through another intermediary author (such as Gregory the Great or Isidore). D. A. Bullough writes:

[...] how much of the Doctor's [Augustine's] massive oeuvre he [Alcuin] read over his lifetime is only dimly recoverable from his own writings [...] and how far he [Alcuin] had followed or endeavoured to follow the sophisticated argumentation of Augustine's major treatises is hardly clearer. ${ }^{3}$

On the other hand, Bullough is convinced of the impact Augustine's work had on Alcuin, particularly as far as political thought was concerned:

It is impossible to imagine Alcuin without Augustine [...] Alcuin's familiarity in his York years with all or a substantial part of Augustine's De civitate Dei, and its consequent influence on his thinking about kingship and emperordom, has been widely assumed. ${ }^{4}$

However, Bullough does not go into detail about Augustine and Alcuin's common ground on ideas of rulership and empire, and leaves the matter fairly open.

The approach taken in this study of Augustine's influence on Alcuin's work is as follows: in the first chapter, a sample letter from Alcuin to Charlemagne, 
which includes various explicit references to Augustine, is taken as a starting point, in order to see in what manner and for what purpose Augustine is formally represented in Alcuin's correspondence. The essence of the letter, its structure and the development of the argument are outlined to show how Alcuin incorporated Augustine into his reasoning. References are made to other letters in order to establish correspondences in structure.

The second chapter is concerned with parallels in political thought between Augustine and Alcuin - with emphasis on the notions of kingship/imperial authority and the value of rulership in the context of God's providential plan. The question of the salvific meaning Alcuin attributes to the Carolingian realm, compared and contrasted with that which Augustine assigns to earlier supreme worldly 'states' in the De civitate Dei, constitutes a key aspect of the discussion. I explore whether Alcuin sees Charlemagne as a successor to the Roman emperors and Old Testament kings. Thereby, Alcuin's Epistolae to Charlemagne and to other figures of religious and political importance form one part of the material under examination; another part is provided by Alcuin's Carm. 1 and the Vita Willibrordi archiepiscopi Traiectensis. As a complement to the content analysis, a formal analysis of said sources, concerned with Alcuin's language, follows. It focuses on selected Augustinian ${ }^{5}$ concepts found in the De civitate Dei which I regard as being particularly crucial (or which have been highlighted as such in the existing secondary literature), and which also have a bearing on the Carolingians. These concepts include, for instance, the political terms civitas Dei, populus Christianus and imperium Christianum (discussed by F. L. Ganshof ${ }^{6}$ ), regna terrarum, imperium and gentes (discussed by Bullough ${ }^{7}$ and $\mathrm{R}$. $\mathrm{McKitterick}^{8}$ ); the expressions subicere, subdere and subiugare/iugum; the concept of dispensatio as well as elements of the doctrine of Augustinisme politique as defined by H.-X. Arquillière9 in the mid-1930s. The meaning and function of these concepts, terms and expressions in Alcuin's texts are compared with those found in Augustine's own.

In the course of this investigation, Augustine emerges as heavily represented both through direct quotation and through indirect reference visible in the content and language of the sources. At the same time, an essential difference in the aim of explicit and implicit references to Augustinian thought is revealed; on the surface, Alcuin explicitly avails himself of Augustine as a pre-eminent authority and binding guideline in matters relating to Christian doctrine. His use of Augustinian thought in this sense is straightforward. However, a deeper reading that takes into account content as well as language and views of Alcuin's texts as a political discourse discloses a more complex scheme on the author's part. Alcuin draws on the most negative of all Church Fathers in terms of assessing worldly rule and rulership in order to make a positive statement about Charlemagne and the Carolingian 'state'.

\section{Alcuin's Epistle 307}

The letter under analysis in this chapter is Alcuin's Epist. 307, sent to Charlemagne within the first few years after his imperial coronation (Charlemagne is addressed 
as excellentissime imperator ${ }^{10}$ ). The letter as a whole appears to be instructional, ${ }^{11}$ and there seems to be no other underlying purpose for writing it. Alcuin's instruction to Charlemagne begins in the first line after the greeting ${ }^{12}$ and ends with the letter itself. ${ }^{13}$ The letter opens by introducing the philosophical concept of sapientia ("wisdom"), which Alcuin defines in agreement with the "philosophers" as "the knowledge of divine and human affairs."14 Alcuin praises Charlemagne for being inclined to seek sapientia from the people surrounding him, including Alcuin himself as a teacher, in order that perfection of intellect and character may be spread to all people. ${ }^{15}$ Charlemagne's thirst for gathering wisdom, Alcuin says, provides the impetus for his interest in the complexities of Christian doctrine. In this letter, the problem under discussion is one raised by an unnamed "learned Greek" regarding the pretium ("price") paid for the salvation of the human race. ${ }^{16}$ About this learned Greek, Alcuin says:

That aforementioned wise man is said by certain sons of Catholic learning at the palace to have enquired about which price was given to whom, and - as his wisdom was apparent to those who heard him - wished to establish that death was the receiver of this price; thinking that there could be no redemption without someone to receive the price from the purchaser and to give something of his own to the purchaser for the price received; he has also endeavoured to confirm this by the judgment of apostolic authority, because it was said: "Death reigned from Adam to Moses."17

Before Alcuin sets out his argument on the matter and starts engaging with the hypothesis offered by the Greek sage, he announces that he will base his comments on the views of the Fathers. ${ }^{18}$ His words are:

In order to avoid saying anything thoughtless, I will begin to respond to the profundity of his [the wise man's] question through the opinions of the Fathers; and if I wished to respond to his obscurity, the size of a book would be necessary; nevertheless, I will restrain my pen so that it does not exceed the length of a longer letter. ${ }^{19}$

Alcuin begins his instruction by elaborating on the meaning of the word mors ("death") as used by the Apostle Paul. ${ }^{20}$ Further down, Alcuin exhorts Charlemagne not to misinterpret a passage in the New Testament by assuming that the spilt blood from Christ's side stayed behind on earth in order to be spared from death. ${ }^{21}$ Here, Alcuin bases his instruction on Book IV of Augustine's De trinitate; it is the entire body of Christ that escapes death. ${ }^{22}$ In order to reinforce his position, Alcuin draws on Fulgentius, Bishop of Ruspe, who also affirmed the physical integrity of Christ after his resurrection. ${ }^{23}$ Using Cassiodorus, Alcuin demonstrates that Christ gave to his people the ransom he earned through his suffering. ${ }^{24}$ In addition, Alcuin finds it necessary to delve further into the problem of whether "death" demanded and took the pretium from the redeemer or whether "death" itself was the pretium of redemption. ${ }^{25}$ In order to give a meticulous 
commentary on the function of "death" in Christ's act of redemption, Alcuin once more uses Augustine as his main source of reference. Again, Alcuin explicitly cites Book IV of the work De trinitate, which, according to him, gives the most detailed information on "death." ${ }^{26}$ From there, Alcuin quotes a passage that makes clear why "death" is deserved by mankind but not by Christ. This passage says that mankind came to "death" through sin, whereas Christ did so through justice; hence our "death" is the punishment for our sin and his "death" the sacrifice for our sin. ${ }^{27}$ From another chapter of Book IV of the De trinitate, Alcuin draws the statement that Christ was not put to death by the judgment of some authority or power, but died willingly, choosing earthly authorities to enact his will. ${ }^{28}$ Alcuin continues quoting from Book IV and calls attention to a chapter entitled "about the perfect and true sacrifice which the saviour himself made for us." He praises this chapter, which concerns itself with who the sacrificing priest was, who the sacrifice was, and for whom or by whom the sacrifice was made, for its outstanding elucidation of the Trinity. ${ }^{29}$ In two lengthy quotations, Alcuin first demonstrates that the Son of God was the perfect priest, as a result of not being a sinner either through inheritance or through his own deeds, and thus not in need of washing his own sins away by making a sacrifice. ${ }^{30}$ Secondly, he shows that in making this human sacrifice, which was so desperately needed by all men, the sacrificer and the sacrifice were one and the same, and were also at one and in agreement with the receiver of the sacrifice, God the Father. ${ }^{31}$ At the same time, the four key aspects of the sacrifice are explained: for whom the sacrifice was made, by whom it was made, what it was and on whose behalf it was performed. ${ }^{32}$ Alcuin considers Augustine's statements in order to constitute ample evidence that the sacrifice or price was meant for, and was received by, God the Father. ${ }^{33}$ Following this line of argument, Alcuin uses another quotation from Augustine, drawn from his commentary on Psalm 58, where it is shown that Christ's suffering first led to his death and then to his resurrection. ${ }^{34}$ Alcuin then mentions the parallel between Isaac in the Old Testament, who carried the cross on his shoulders for his own sacrifice, and the Passion of Christ in the New Testament, which was purposefully initiated by God. ${ }^{35}$ As a last piece of evidence from one of the Fathers, underlining that Christ was at the same time the sacrificer and the sacrifice, Alcuin quotes Cyprian, Bishop of Carthage, whom he refers to as an outstanding scholar and glorious martyr. ${ }^{36}$ The remaining part of the letter debates a question reportedly posed by Paul and aimed at the Stoics from the Athenian school of philosophy: the question of whether "death" is substantia ("matter"). ${ }^{37}$

Looking at the structure of Epist. 307, three noticeable features mark the beginning of Alcuin's instructional correspondence: first, Alcuin uses the positive philosophical concept of sapientia when addressing Charlemagne in order to motivate the emperor and, most importantly, encourage him to absorb the Catholic Christian doctrine. Second, he confirms and praises Charlemagne's interest in the subject matter to be elucidated. Third, in order to integrate his own thoughts into an existing discourse and present an orthodox argument, at the very outset, Alcuin highlights the importance of the views of the Fathers in this discussion. 
Augustine is only one of several patristic sources consulted by Alcuin, but he is arguably presented in a different way from the others. Alcuin's citations from Augustine appear alongside - and are at times intertwined with other phrases from saints and scholars, as well as with quotations from the Scriptures. Apart from the Bible and Augustine, the authors cited in the letter are Fulgentius, ${ }^{38}$ Cassiodorus $^{39}$ and Cyprian, ${ }^{40}$ in that order. Strikingly, all citations from Augustine are referenced (even if only imprecisely); they are all drawn from the De trinitate, mostly Book IV, except for a single quote from his commentary on Psalm 58. ${ }^{41}$ Quotations from other writers, however, are not referenced in this precise manner, with the exception of the phrase from Fulgentius, which is said to be part of his best-known work, De fide. ${ }^{42}$ Moreover, Augustine is the only author (besides the evangelists) who keeps recurring in the text. Having identified Augustine as Alcuin's prime reference in this correspondence, two further observations need to be made regarding the position and prominence of Augustine's opinion in the text; Augustine is the first author (again, apart from the evangelists) to be brought into the discussion, and already at his first mention the De trinitate is introduced. ${ }^{43}$ This work is then used as a principal source to refute the misinterpretation that death had any impact on Christ's body. ${ }^{44}$ The quotation from Fulgentius that follows Augustine's statement is clearly placed in a position of secondary importance. The second instance where Alcuin has recourse to Augustine is even more remarkable. At this point, Alcuin writes that he finds it indispensable to investigate much more rigorously the role played by "death" in Christ's act of redemption. ${ }^{45}$ Here, Augustine's argument becomes prominent. The entire elucidation that follows is put together by collating extended quotations from Augustine's De trinitate and, finally, from his commentary on Psalm 58. ${ }^{46}$ This part of the letter clearly reveals that Alcuin very much relies on Augustine when there are intricate theological problems to spell out. By quoting Augustine, Alcuin can give the reader multiple pieces of information within a few lines. ${ }^{47}$ Last but not least, Alcuin himself repeatedly stresses Augustine's outstanding eloquence and reasoning in the letter. ${ }^{48}$

\section{Comparison with other Epistles}

Epist. 307 presents clear similarities with other letters written by Alcuin (both letters addressed to Charlemagne and those addressed to other acquaintances) in terms of his methods of reasoning and citation (including citation from Augustine $^{49}$ ), as well as in his form of address to the correspondent.

The mobilisation of sapientia with reference to Charlemagne, for example, is a recurring theme in Alcuin's letters. References to sapientia can accompany the beginning ${ }^{50}$ or end ${ }^{51}$ of a letter, where they tend to feature as part of a formulaic greeting or complimentary closing; or they can occur elsewhere ${ }^{52}$ in the text. Such references almost always serve to inspire Charlemagne and influential members of the court to internalise and propagate the Catholic doctrine and, crucially, to take note of Alcuin's opinion. 


\section{Alcuin of York}

In Epist. 110, for instance, Alcuin instructs the king on baptism and the procedure for converting newly subdued peoples ${ }^{53}$; first discussing the Saxons,${ }^{54}$ then the Avars. ${ }^{55}$ Afterwards, Alcuin exhorts Charlemagne:

But now your most wise, God-placating devotion should provide pious preachers for the new people; honest in character, learned in the knowledge of the sacred faith and imbued with evangelical precepts; also intent on preaching the words of God through the examples of the saintly apostles. ${ }^{56}$

In Epist. 136 and Epist. 111, Alcuin explains that conversion to the Christian faith should not be forced by the sword, but should be achieved by the words of God. ${ }^{57}$ In doing so, Alcuin makes reference to the concept of sapientia ${ }^{58}$ and to Augustine $^{59}$ as the prime authority in questions relating to the correct Christian doctrine and the correct propagation of faith.

Early on in Epist. 111, before discussing good practice in conducting missionary work, Alcuin highlights:

Belief, namely, as Saint Augustine says, is a voluntary not a necessary act. ${ }^{60}$

Thus, the cardinal principle of faith being formed through free will is based on Augustine.

At the beginning of Epist. 136, Alcuin writes:

By these praiseworthy letters of your wisdom, as you are accustomed to, I managed to want to wake my sluggishness shrewdly through prudent questions; I realised indeed to teach better by enquiries than to study the unknown.

For to ask wisely is to teach, just as we found it written on a page of your authority. ${ }^{61}$

In order to convince Charlemagne to take notice of and act on what he says, Alcuin emphasises the reciprocal relationship between him and the king. He puts forward that it was first and foremost Charlemagne's wise enquiries, his curiosity and eagerness for knowledge that helped him reach these important conclusions.

Likewise, Alcuin's mode of reasoning and way of quoting sources in Epist. 307 finds parallels in other letters. For example, as far as the composition of Epist. 110 is concerned, a similar arrangement of sources can be found; as one would expect in a correspondence dealing with conversion and baptism, the Apostle Paul ${ }^{62}$ and the Gospel ${ }^{63}$ are quoted. From the Fathers, the views of Jerome and Augustine are featured in the text. The letter contains three quotations from Jerome, ${ }^{64}$ of which the first one is not referenced, and the other two are drawn from his commentary on the Gospel of Matthew. The letter to the king closes with a detailed summary ${ }^{65}$ of the procedure for converting heathens proposed by Augustine in his 
De catechizandis rudibus. ${ }^{66}$ Alcuin rates this work as very important and useful for Charlemagne. He states:

Therefore, that order in teaching a man already grown is to be observed, diligently, as I believe, which the blessed Augustine set out in the book that he titled de catecizandis rudibus. ${ }^{67}$

Subsequently, Alcuin outlines the main points to consider in the process of conversion. He notes the following: first, the catechumen needs to be instructed on the immortality of the soul, the future life, and the retribution for good and evil as well as the infinite quality of each of these fates. ${ }^{68}$ After this, he should learn for which sins and crimes one suffers eternal punishment with the devil, and for which virtues or good deeds one enjoys eternal glory with Christ. ${ }^{69} \mathrm{Next}$, the faith of the Holy Trinity must be taught most diligently, and the coming of Christ, the Son of God, for the benefit of mankind needs to be explained; equally, the mystery of his Passion, the truthfulness of his resurrection, the glory of his ascension into heaven, his Second Coming to judge all people, the resurrection of our bodies and the eternity of the punishments for the evil and of the rewards for the good. In this way, a new awareness is formed quickly, ${ }^{70}$ and the man, confirmed by his faith, is ready to be baptised. ${ }^{71}$ Then, at a convenient time, evangelical rules have to be given more often through a service of diligent praise, until his faith is consolidated, and he has become a perfect son of God. ${ }^{72}$ From this abstract, it can be seen that Alcuin indeed wanted Charlemagne to follow Augustine's directions and that he used Augustine's authority to persuade the king away from his current course.

Another piece of correspondence worth considering in this regard is Alcuin's Epist. 182. It is a letter arguing against Adoptionism. Alcuin reasons that Christ is not only human but also divine. Consequently, Christ could not have been adopted. He is both the Son of God and human. Striking in this letter is that, already in the greeting, Alcuin announces the opinions of the Fathers that will be prominent in the text. He mentions Ambrose, Augustine, Isidore and Jerome. ${ }^{73}$ Apart from them, Alcuin quotes Cyprian ${ }^{74}$ and Gregory the Great ${ }^{75}$ and moreover names Athanasius ${ }^{76}$ and Hilary ${ }^{77}$ in the correspondence. Just as in Epist. 307, the voices of the prophets ${ }^{78}$ and the apostles ${ }^{79}$ are represented alongside other Biblical quotations. Augustine is named and quoted several times. ${ }^{80}$ Similar to Epist. 110, the representation of Augustine's voice, which appears towards the end of the letter, is extremely strong compared to the quotations Alcuin uses from other authors. ${ }^{81}$

A first step in the analysis of Alcuin's sources has been to locate explicit references to Augustine in Alcuin's correspondence. It has emerged that the epistles in which Augustine is prominent by direct quotation at some level all have an instructional component. Thus, those letters addressed to Charlemagne additionally make calls on his sapientia, which is used as a tool of encouragement for him to learn and spread the correct Christian doctrine. It is fair to say that in Alcuin's correspondence Augustine features directly as the leading authority in questions of faith. He appears to be Alcuin's prime reference for the following 
reasons: first, compared to other authors and texts, Augustine is named and cited more frequently and more rigorously (Epist. 307, Epist. 110, Epist. 182); second, Augustine's articulateness and logic are repeatedly praised by Alcuin (Epist. 307); third, quotes from Augustine are more often given a precise textual reference than quotes from other authors (Epist. 307); fourth, Augustine usually occupies a key position in the letter, i.e. he is mentioned in the opening (Epist. 307) or in the closing (Epist. 110, Epist. 182) of the text; finally, Alcuin relies more heavily on Augustine when complex theological questions are being debated, because Augustine's texts contain concentrated information in a few lines (in Epist. 307 the De trinitate is used to disprove misinterpretations, while Epist. 110 ends with an accurate review of the method of conversion suggested by Augustine in the De catechizandis rudibus). This evidence shows that Alcuin really wanted Charlemagne to follow Augustine's directions in matters of faith above all others, and was promoting him as holding an overriding authority in a way that bolstered his own.

\section{Notes}

1 On Alcuin's background and his career at Charlemagne's court, see Bullough 2004; Brunhölzl 1967; Fleckenstein 1967; 1990; Steinen 1967. Regarding Alcuin's literary influences, Bullough 2004 argues that, in addition to Augustine, Cicero, Virgil and Isidore of Seville were prominent in shaping Alcuin's work.

2 M. Kempshall's analysis of Alcuin's treatise Disputatio de rhetorica et de virtutibus is worth mentioning here. Kempshall does not refer to any methodology explicitly his investigation is entirely guided by the Latin text. Kempshall examines the various sources Alcuin uses in his argument (inter alia Cicero, Augustine and Quintilian). Kempshall 2008, p. 7. Augustine's De civitate Dei and Contra Iulianum are mentioned alongside the De musica and the De doctrina christiana. Ibid., pp. 17-23. Kempshall convincingly argues that Alcuin makes his adaptation of Cicero appropriate to a Christian context of learning by raising the relevant question of the value of natural vs. Christian virtues treated in the De civitate Dei and Contra Iulianum. Ibid., p. 17. See also Renswoude van 2008, pp. 393-413. In my research-, Augustine's political ethics (as they appear in the De civitate Dei) are explored in Part III of the book. Hincmar of Rheims' work contains a much more detailed treatment of Christian virtues, in combination with moral instruction for rulers. Unlike Hincmar's work, De regis persona et regio ministerio, none of Alcuin's treatises fulfil the criteria to be categorised as 'mirrors for princes'. Ibid., p. 9. H. H. Anton and J. M. Wallace-Hadrill both question L. Wallach's thesis that Alcuin's Disputatio de rhetorica et de virtutibus belongs to the genre of treatises on kingship; Anton instead highlights the importance of Alcuin's correspondence. Anton 1968, pp. 87-88; Wallace-Hadrill 1971, p. 101.

3 Bullough 2004, p. 261.

4 Ibid., pp. 261-262.

5 By 'Augustinian', I refer to the thought that is manifested in Augustine's later work - in particular the De civitate Dei.

6 Ganshof 1949.

7 Bullough 1999.

8 McKitterick 2004.

9 Arquillière 1934.

10 Most excellent emperor. Epist. 307, p. 466, lin. 24.

11 That Alcuin's relationship with Charlemagne is a friendship based on eruditio ("instruction") is shown by Wallace-Hadrill 1971, pp. 101-102. See also 3.2. Charakteristika 
des Lehrens in den Briefen Alkuins in Steckel 2011, pp. 156-161. Alcuin's exceptional role as a public adviser is explored by M. Garrison. She describes key traits of his character (e.g. knowability, social skills, self-perception) and work (discourse of admonition) that helped him to gain a unique status in and outside the court circle. Garrison 2010, pp. 137-151.

12 Epist. 307, p. 466, lin. 23.

13 Ibid., p. 471, lin. 6.

14 Ibid., p. 466, lin. 23.

15 Ibid., p. 466, lin. 24.

16 Ibid., p. 466, lin. 28.

17 Quod precium cui daretur, sapiens ille praedictus a quibusdam catholicae eruditionis filiis in palatio inquirere dicitur et - ut visum est eius sapientiam audientibus - velle eum adstruere huius precii acceptricem esse mortem; putans redemptionem esse non posse, nisi forte esset, qui precium accepisset ab emptore atque aliquid sui iuris emptori pro precio tradidisset accepto; hoc ipsum quoque apostolicae auctoritatis sententia confirmare nisus, quia dictum est: "Regnavit mors ab Adam ad Moysen." Ibid., p. 466, lin. 31 .

18 Ibid., p. 467, lin. 1.

19 Ad cuius questionis profunditatem, ne quid temere dicam, sensibus patrum respondere ingrediar; adque eius obscuritatem si respondere velim, magnitudine libri opus erit; tamen ita temperabo calamum, ut longioris epistolae modum non excedat. Ibid., p. 467, lin. 1.

20 Ibid., p. 467, lin. 4.

21 Ibid., p. 468 , lin. 28.

22 Ibid., p. 468, lin. 28-34.

23 Ibid., p. 468, lin. 35.

24 Ibid., p. 468, lin. 42.

25 Ibid., p. 469, lin. 5.

26 Ibid., p. 469, lin. 7.

27 Ibid., p. 469, lin. 9.

28 Ibid., p. 469, lin. 11-15.

29 Ibid., p. 469, lin. 16.

30 Ibid., p. 469, lin. 19-22.

31 Ibid., p. 469, lin. 22.

32 Ibid.

33 Ibid., p. 469, lin. 28.

34 Ibid., p. 469, lin. 36-38.

35 Ibid., p. 469, lin. 41-42.

36 Ibid., p. 469, lin. 44-p. 470, lin. 1.

37 Ibid., p. 470, lin. 19, 27.

38 Ibid., p. 468, lin. 35.

39 Ibid., p. 468, lin. 42.

40 Ibid., p. 469, lin. 44-p. 470, lin. 1.

41 Ibid., p. 469, lin. 36-38.

42 Ibid., p. 468, lin. 35.

43 Ibid., p. 468, lin. 28.

44 Ibid., p. 468, lin. 28-34.

45 Ibid., p. 469, lin. 5.

46 Ibid., p. 469, lin. 7-38.

47 See particularly the quotation used on p. 469 , lin. 22.

48 Ibid., p. 468, lin. 28, p. 469, lin. 15-16.

49 On Alcuin's use of the Church Fathers in theological debates, see Otten 1997, pp. 3-50.

50 Epist. 136, p. 205, lin. 16; Epist. 178, p. 294, lin. 21; Epist. 257, p. 414, lin. 20.

51 Epist. 249, p. 404, lin. 7. 


\section{Alcuin of York}

52 Epist. 110, p. 157, lin. 22; Epist. 111, p. 161, lin. 13, 18; Epist. 136, p. 207, lin. 26; Epist. 177, p. 292, lin. 29-33; Epist. 202, p. 335, lin. 21, 24; Epist. 257, p. 415, lin. 6.

53 I agree with Wallace-Hadrill that eruditio ("instruction") for Alcuin was always linked to the idea of national salvation. Alcuin advised Charlemagne to be aware of his important function as the founder of a new Christian community. Wallace-Hadrill 1971, p. 102.

54 Epist. 110, p. 157, lin. 13.

55 Ibid., p. 157, lin. 18.

56 Sed nunc praevideat sapientissima et Deo placabilis devotio vestra pios populo novello praedicatores; moribus honestos, scientia sacrae fidei edoctos et evangelicis praeceptis inbutos; sanctorum quoque apostolorum in praedicatione verbi Dei exemplis intentos. Ibid., p. 157, lin. 22.

57 A study of how Charlemagne was criticised, especially after 814, is provided in Collins 1998, pp. 193-211.

58 Epist. 111, p. 161, lin. 13, 18; Epist. 136, p. 205, lin. 16, 18.

59 Epist. 111, p. 160, lin. 19.

60 Fides quoque, sicut sanctus ait Augustinus, res est voluntaria, non necessaria. Epist. 111, p. 160, lin. 19.

61 In quibus laudabilibus quoque vestrae sapientiae apicibus meam, ut soliti estis, segnitiem per interrogationes prudentissimas sagaciter excitare velle inveni; immo per inquisitiones magis docere, quam ignorata discere agnovi.

Quia sapienter interrogare docere est, veluti in vestrae auctoritatis pagina scriptum repperimus. Epist. 136, p. 205, lin. 16-18.

62 Epist. 110, p. 157, lin. 25-28, p. 158, lin. 17, 33.

63 Ibid., p. 157, lin. 31.

64 Ibid., p. 158, lin. 1, 20-25, 28.

65 Ibid., p. 158, lin. 36-p. 159, lin. 10.

66 See Bouhot 1980, pp. 176-240 on Alcuin's use of Augustine's De catechizandis rudibus and Phelan 2010, pp. 455-474 on Alcuin's adaptation of Augustine's catechetical programme for missionary purposes among the Avars.

67 Igitur ille ordo in docendo virum aetate perfectum, diligenter, ut arbitror, servandus est, quem beatus Augustinus ordinavit in libro, cui de catecizandis rudibus titulum praenotavit. Epist. 110, p. 158, lin. 36.

68 Ibid., p. 158, lin. 38.

69 Ibid., p. 159, lin. 2.

70 Ibid., p. 159, lin. 3.

71 Ibid., p. 159 , lin. 9.

72 Ibid., p. 159, lin. 10.

73 Epist. 182, p. 301, lin. 1.

74 Ibid., p. 307, lin. 1.

75 Ibid., p. 301, lin. 20.

76 Ibid., p. 302, lin. 36.

77 Ibid.

78 Ibid., p. 304, lin. 12.

79 Ibid., p. 302, lin. 4, p. 304, lin. 40.

80 Ibid., p. 301, lin. 1, p. 302, lin. 36, p. 303, lin. 27, p. 305, lin. 41, p. 306, lin. 3-29.

81 Ibid., p. 306, lin. 3-20.

\section{Bibliography}

\section{Primary sources}

Alcuinus: Carmina. Ernst Dümmler (ed.) (MGH AN Poet. Lat. 1). Berlin, 1881. 
Alcuinus: De pontificibus et sanctis ecclesiae Eboracensis. Peter Godman (ed.). Oxford, 1982.

Alcuinus: Epistolae. Ernst Dümmler (ed.) (MGH Epp. 4). Berlin, 1895.

\section{Secondary sources}

Anton, Hans Hubert: Fürstenspiegel und Herrscherethos in der Karolingerzeit. Bonn, 1968.

Arquillière, H.-X.: L'Augustinisme politique: Essai sur la formation des théories politiques du Moyen-Âge. Paris, 1934.

Bouhot, Jean-Paul: Alcuin et le "De catechizandis rudibus" de Saint Augustin. Recherches Augustiniennes: Supplément à la revue des études Augustiniennes 15, 1980, 176-240.

Brunhölzl, Franz: Der Bildungsauftrag der Hofschule, in: Bernhard Bischoff (ed.): Das geistige Leben, Karl der Grosse: Lebenswerk und Nachleben vol. 2. (3rd ed.). Düsseldorf, 1967, 28-41.

Bullough, Donald A.: Die Kaiseridee zwischen Antike und Mittelalter, in: Christoph Stiegemann and Matthias Wemhoff (eds.): Kunst und Kultur der Karolingerzeit: Karl der Grosse und Papst Leo III. in Paderborn: Beiträge zum Katalog der Ausstellung, Paderborn 1999. Mainz, 1999, 36-46.

Bullough, Donald A.: Alcuin: Achievement and Reputation: Being Part of the Ford Lectures Delivered in Oxford in Hilary Term 1980. Leiden, 2004.

Collins, Roger: Charlemagne and His Critics (814-829), in: Régine Le Jan (ed.): La royauté et les élites dans l'Europe carolingienne (début IXe siècle aux environs de 920). Villeneuve d'Ascq, 1998, 193-211.

Fleckenstein, Josef: Karl der Grosse und sein Hof, in: Helmut Beumann (ed.): Persönlichkeit und Geschichte, Karl der Grosse: Lebenswerk und Nachleben vol. 1. (3rd ed.). Düsseldorf, 1967, 24-50.

Fleckenstein, Josef: Karl der Grosse. (3rd ed.). Göttingen and Zürich, 1990.

Ganshof, François Louis: The Imperial Coronation of Charlemagne: Theories and Facts. Glasgow, 1949.

Garrison, Mary: An Aspect of Alcuin: 'Tuus Albinus' - Peevish Egotist? Or Parrhesiast?, in: Richard Corradini et al. (eds.): Ego Trouble: Authors and Their Identities in the Early Middle Ages. Wien, 2010, 137-151.

Kempshall, Matthew: The Virtues of Rhetoric: Alcuin's Disputatio de Rhetorica et de Virtutibus. Anglo-Saxon England 37, 2008, 7-30.

McKitterick, Rosamond: History and Memory in the Carolingian World. Cambridge, 2004.

Otten, Willemien: The Texture of Tradition: The Role of the Church Fathers in Carolingian Theology, in: Irena Backus (ed.): The Reception of the Church Fathers in the West: From the Carolingians to the Maurists vol. 1. Leiden, 1997, 3-50.

Phelan, Owen M.: Catechising the Wild: The Continuity and Innovation of Missionary Catechesis under the Carolingians. The Journal of Ecclesiastical History 61(3), 2010, 455-474.

Renswoude van, Irene: The Word Once Sent Forth Can Never Come Back: Trust in Writing and the Dangers of Publication, in: Petra Schulte, Marco Mostert and Irene Renswoude van (eds.): Strategies of Writing: Studies on Text and Trust in the Middle Ages. Turnhout, 2008, 393-413.

Steckel, Sita: Kulturen des Lehrens im Früh- und Hochmittelalter: Autorität, Wissenskonzepte und Netzwerke von Gelehrten. Köln, 2011. 


\section{Alcuin of York}

Steinen, Wolfram von den: Der Neubeginn, in: Bernhard Bischoff (ed.): Das geistige Leben, Karl der Grosse: Lebenswerk und Nachleben vol. 2. (3rd ed.). Düsseldorf, 1967, 9-27.

Wallace-Hadrill, John Michael: Early Germanic Kingship in England and on the Continent: The Ford Lectures Delivered in the University of Oxford in Hilary Term 1970. Oxford, 1971. 


\section{Alcuin's indirect use of Augustine His stance on worldly rule and recourse to Augustine's terminology}

In the first part of the book that discussed Augustine of Hippo's thoughts on rulership, his assessment of 'states' and their integration into God's providential plan, I observed the following: an unfolding tension in the De civitate Dei that reflects Augustine's dilemma between approval of the supreme worldly power of Christian (and to some extent pagan) rulers and harsh criticism of any form of worldly social organisation, government and power. Despite his negative view of worldly affairs, Augustine arrives at the judgment that it is the greatest bliss for the condition of human beings on earth if people come to power who are granted a strong belief in Christianity, hence true virtuousness, and in addition a talent in ruling over nations. Augustine presents the Christian rulers in just this manner. However, according to Augustine, all members of a 'state', including its ruler, must place themselves completely under the authority of God in order to achieve justice, the essential precondition for a 'state' (as claimed by Cicero in Book I of his De re publica ${ }^{1}$ ) - something that he considered was not in fact achievable in practice. In the work De civitate Dei, the ruler or emperor is not discussed as being in essence different from other human beings as a result of their function.

In what follows, an attempt is made to look for implicit forms of Augustine's influence on Alcuin of York by analysing Alcuin's writing as a comprehensive political discourse. Alcuin's stance on worldly rule is examined in the content of the Epistolae, Carm. 1 and Vita Willibrordi archiepiscopi Traiectensis. I concentrate on the representation of Roman emperors and Old Testament kings and then focus on the language in these same sources. Bearing in mind Augustine's thoughts on worldly power, I explore the extent to which Alcuin saw Charlemagne as a successor to the Roman emperors and Old Testament kings, and what he thought the ruler's function should be with regard to secular and religious duties. I evaluate the place Alcuin allocates to Charlemagne and his realm within God's providential plan. In the process of the analysis, I attempt to explain the intention behind Alcuin's implicit use of Augustine and present a hypothesis on the difference in aims between the direct quotation of and indirect reference to Augustine. 


\section{Alcuin on rulership and Roman emperors}

Alcuin's letter Epist. 246 was written to Theodulf of Orléans around 801/802, i.e. after Charlemagne's imperial coronation. ${ }^{2}$ It is part of a cluster of epistles (Epist. 245-Epist. 249) concerning a well-known conflict in Tours, edited by E. Dümmler. A dispute flared up when a sinful cleric took refuge in the Basilica of Saint-Martin de Tours, involving the community, with Alcuin as its abbot and Archbishop Theodulf of Orléans as his adversary, himself a former fellow adviser to Charlemagne. ${ }^{3}$ R. Meens draws attention to the importance of the right of sanctuary and the practice of penance in the management of conflicts in the Carolingian age. ${ }^{4}$ By examining the argument between Alcuin and Theodulf, Meens points out existing conflicting views on sin and crime, penance and punishment at the Carolingian court. A cleric was judged and found guilty in Orléans by Theodulf for some unknown serious crime. The tribunal where he was sentenced was presided over by Theodulf, and a canonical penance was imposed on the cleric. ${ }^{5}$ However, despite being put in chains, the cleric managed to escape. He found refuge in the Basilica of Saint-Martin de Tours, where he apparently appealed to the emperor and requested safe conduct to him. Theodulf dispatched a group of men to Tours to retrieve the convict, and Alcuin affirms that the monks of Saint-Martin were ready to hand him over. Yet Theodulf's men, having heard rumours about an ambush, left the cleric in front of the 'church' and returned empty-handed. Full of anger, Theodulf sent a small army to fetch the prisoner by force. The army collaborated with Joseph, Bishop of Tours, who escorted eight of them on a Sunday into the crowded Basilica to capture the cleric - an action clearly condemned by Alcuin. ${ }^{6}$ This intrusion was followed by an uproar in the 'church' and terror and turmoil, especially among the poor, in the city. Subsequently, Theodulf wrote a letter of complaint to the emperor. This piece has not survived, but Alcuin refers to it in his own correspondence. ${ }^{7}$ The exact nature of Theodulf's criticism is unknown; however, the extant texts suggest that Theodulf complained to Charlemagne about disrespect towards his own men, as well as Joseph's, on the part of Alcuin and the monks of Saint-Martin during the upheaval. A further accusation was that of disrespect for the emperor's written order to hand over the fugitive. Alcuin thought that Charlemagne's command was unjust. According to Alcuin, the injustice lay in capturing offenders seeking sanctuary in sacred places as well as hindering a person from appealing to the ruler. ${ }^{8}$ This perspective is reflected in Alcuin's correspondence, and the way he went about justifying himself is significant.

Epist. 246 is also remarkable because it links Charlemagne as an emperor with the Roman imperial tradition. The letter cites laws concerning the right of sanctuary, which had been enacted by Roman emperors. Alcuin mentions laws imposed by Constantine I, Theodosius II, Valentinian and Honorius, to the effect that anyone prosecuted by the law might find shelter and be protected from a judge in any 'church' consecrated by the emperor.' Alcuin justifies the importance of this law by saying that every sinner and offender devoted to the Christian God needs a place of refuge and safety from prosecutors. He begs Theodulf to understand that 
this law is authorised for refugees in the protectorates. To reinforce his appeal, he adds that he is certain that the most Christian and noble emperor Charlemagne would never legislate differently from his predecessors, the Roman emperors. Alcuin evidently presents the above-named Roman emperors as Charlemagne's antecessores. It is in this very statement that Alcuin uses the name Carolus for the first and only time in this letter. Before, he refers to the emperor using the pseudonym David. Considering that Alcuin's main concern was to promote a law that was in force under Roman emperors, it makes sense at this point to use the ruler's proper name and not his pseudonym, which had a strong spiritual connotation. It is undeniable that linking Charlemagne to the Roman imperial tradition was Alcuin's strategy to put the ruler under an obligation to acknowledge and uphold a certain law that used to be in force during the Roman imperial period. ${ }^{10}$

Towards the end of the letter, Alcuin gives a clear explanation for why he deems it indispensable for the 'churches' of Christ in Charlemagne's realm to have the additional function of providing shelter to Christian refugees; he says that it is imperative that neither the dignity of the 'church', nor fear and reverence for it, should be smaller in the most excellent regnum ("realm") and most powerful imperium ("empire"). Instead, they should continually grow for the praise and glory of Jesus Christ who honoured Charlemagne above all other kings and emperors with the beauty of sapientia ("wisdom") and exalted him with the potentia regni ("power of reign"). This declaration manifests unmistakably that, even though with reference to legal matters Charlemagne is ranked among the Christian Roman emperors, Alcuin thinks of him and his realm as superior to any other earthly power. There is no question that Alcuin's words are also a means of persuading the ruler to rule according to the highest standards, which of course would imply doing what Alcuin advises him to do.

Among the features elevating Charlemagne over all other rulers are, according to Alcuin, the sapientia and potentia regni he had received from the Christian God. These two gifts already appear in Epist. 178, a letter addressed to the king in $800 .{ }^{11}$ In this correspondence, Alcuin strives to convince Charlemagne of the urgency of accepting the imperial title. He argues that God elected Charlemagne among all others to become a supreme ruler by granting him the exceptional gifts of imperium ("supreme power") and spiritalis sapientiae latitudo ("the breadth of spiritual wisdom"). This is one of the writings to the king showing Alcuin's endeavour to instruct Charlemagne in the notion of imperium.

As far as Charlemagne's political and religious responsibilities are concerned, Ganshof argues that it is the ruler's task to govern, defend and extend his realm and at the same time to safeguard faith and 'church'. ${ }^{12}$ There is an epistle, Epist. 257, written to Charlemagne in the aftermath of his imperial coronation, which reflects on Charlemagne's political and religious responsibilities as a ruler. ${ }^{13}$ It is a dedicatory letter for Alcuin's manual De fide sanctae et individuae Trinitatis. ${ }^{14}$ Epist. 257 reveals most clearly the meaning Alcuin attributes to the imperial authority and how he evaluates Charlemagne's worldly realm and ruling power within God's providential plan. Charlemagne is portrayed as an exceptional Christian emperor. Moreover, the writing discloses that the author must 
have had Augustine in mind when composing this text. In the first paragraph of the epistle, Alcuin explains in simple terms what the imperial dignity, with which Charlemagne had recently been invested, is for: it has no other purpose than to "preside over" (praeesse) and "be of use to" (prodesse) the people. To be able to accomplish this task, Alcuin says, potestas ("power") and sapientia ("wisdom") are given by God to the elected. ${ }^{15}$ Here, as in Epist. $178,{ }^{16}$ which dates from before the imperial coronation and gives a direct quotation, Alcuin alludes to the hexameter from Virgil's Aeneid (parcere subiectis et debellare superbos), from the passage in which Anchises prophesies to Aeneas, his son, the future Roman world power. ${ }^{17}$ Augustine also cites this very hexameter in the De civitate Dei, more precisely in Book $\mathrm{V}^{18}$ (which presents the heathen Babylonian and the heathen Roman powers as two eschatologically relevant empires - the Eastern relevant to the Old Testament, the Western relevant to the New Testament due to the fact that God allowed Christ to be born under the Romans' rule). Alcuin states that "power" is used by the ruler ut superbos opprimat ("so that he may oppress the proud") and "wisdom" ut regat et doceat pia sollicitudine subiectos ("so that he may rule and teach the subject peoples with pious concern"). Alcuin tends to remind Charlemagne of the gifts of "(supreme) power" (imperium/potestas/potentia) and "wisdom" (sapientia) granted by God in moments in which he wants to present him as a supreme Christian ruler. It appears that Alcuin strives to link Charlemagne's empire with the Roman and Assyrian realms, which have a notable function in God's providential plan. It also seems that, when using the title of imperator, Alcuin follows Augustine's definition of a "ruler who has the supremacy over other rulers in power" and seeks to equate Charlemagne with the Roman imperatores who are significant in God's providential plan because their empire was meaningful for the development of Christianity. However, in the second paragraph, Alcuin refines the statement made in the first by asserting: "With these two gifts [potestas and sapientia], holy emperor, divine grace has exalted and honoured your sublimity above others, in a manner incomparable to the predecessors of the same title and divine power [...]." ${ }^{19}$ By arguing that divine grace $^{20}$ has endowed Charlemagne with potestas and sapientia to a higher degree than any past or present political agent, Alcuin portrays Charlemagne as superior to any other secular leader and contrasts him with all previous emperors.

While the first paragraph of Epist. 257 only hints at the purpose of these gifts, the following text quite clearly divulges their different function. The second paragraph states that divine grace inflicts the terror of Charlemagne's potentia ("power") upon all the gentes ("races") from all parts, so that those may come to Charlemagne by voluntary subjection, whom the labour of war could not subdue at earlier times. One can see that the various forms of the verb "to subject" (subicere) - which features in Virgil's hexameter quoted by Augustine - build up to a recurrent theme in Epist. 257. What is furthermore implied here is, first, that Charlemagne's gift of "power" has a political function - namely that of expanding and securing his empire. ${ }^{21}$ Second, Alcuin intimates that, after successful victories in war, the remaining unsubdued tribes will eventually bow voluntarily to such a powerful ruler. In other words, Alcuin indicates that the hard times of 
war are over. Accordingly, the rest of the text expands on the role of the second gift of "wisdom," which comes into play after the first gift has fulfilled its purpose. Alcuin continues by asking Charlemagne: "What then, what must be done for your most devoted concern [again: sollicitudo] for God, at a time of serenity and peace [...]?"22 It becomes apparent that Charlemagne's attribute of "wisdom" instead has a religious function. ${ }^{23}$ After drawing the emperor's attention to a sermon on the Holy Trinity, which he composed for Charlemagne in the form of a manual, ${ }^{24}$ Alcuin expands on the significance of "wisdom." He writes:

And that is to say that I neither estimated wisdom to be worthier than any other gift of your imperial majesty: nor did I think any other to be equally worthy of accepting such an excellent gift, as it is very well known that it is necessary for the leader of the Christian people to know everything and preach what pleases God. ${ }^{25}$

To Alcuin, "wisdom" also allows the ruler to discern and make known God's will. ${ }^{26}$ (The same conclusion has already been reached in the first chapter of Part II on the explicit use of Augustine, where it was shown that in letters to Charlemagne, forms of sapientia have in many cases the function of encouraging Charlemagne to learn and spread the correct Christian doctrine taught by Augustine.) Overall, in Epist. 257, Alcuin presents Charlemagne as superior to any other secular authority by claiming that he has gained potestas ("power") and sapientia ("wisdom"), which reflect the ruler's political and religious responsibilities of defending and enlarging his realm and defending and spreading the Catholic Christian faith to a higher degree than any past or present ruling figure.

Alcuin's choice of words when referring to Charlemagne as a Christian emperor together with his people is noteworthy. He chooses princeps populi christiani, which certainly does not make him an ordinary constituent of the Roman imperial tradition. Charlemagne is given a different, superior position. Alcuin adds with regard to Charlemagne's religious responsibility that the emperor above all others needs to know which doctrine can benefit all the subject peoples (again: subiecti). Alcuin ends the debate on the purpose of "wisdom" by saying:

The means for all believers to glorify your piety is manifold, as long as the concern [again: sollicitudo] of your clemency has a priestly vigour, as is seemly, in the preaching of God's words, and a perfected knowledge in the Catholic faith and a most sacred devotion for the well-being of all. ${ }^{27}$

In the conclusion of the epistle, Alcuin then, in line with the requests of all believers, wishes both for Charlemagne's empire to be expanded and for the Catholic faith to be spread. Besides the reference to Virgil's hexameter cited by Augustine in the De civitate Dei, another obvious indication can be found in the text that Augustine was at the forefront of Alcuin's mind when drafting this letter; the opening of the discussion of the function of "wisdom" mentions Alcuin's own handbook on the Holy Trinity. Then, after the significant statement that the 
emperor before everyone else has to know which doctrine will benefit all the people under his power, Alcuin mentions Augustine. He refers to Augustine not only in terms of the work De trinitate, which must have laid the groundwork for the manual but also in connection with Charlemagne's thirst for knowledge in philosophy. One of the main aims of this manual is, according to Alcuin:

[...] and indeed that I convince those, who belittled your most noble intention of wanting to learn the theory of the dialectic discipline, which St. Augustine in the books about the Holy Trinity thought to be necessary in the highest degree, when he demonstrated that the most profound questions concerning the Holy Trinity can only be explained through the subtlety of categories. ${ }^{28}$

\section{Alcuin on rulership and Old Testament kings}

The pseudonyms that were in use among the notables (including the royal family) at the Carolingian court have been studied comprehensively by J. Fleckenstein. ${ }^{29}$ The established pseudonyms for Charlemagne were (novus) David, (novus) Salomon, (novus) Moyse and (novus) Konstantinus. The name David, in particular, made reference to anointing as a sign of God's approval of Charlemagne's assumption of the title of patricius Romanorum. ${ }^{30}$ Responding to H. von Fichtenau and Dümmler, Fleckenstein remarks that the pseudonyms for Charlemagne only appear after 794 (when the king had taken up residence at Aachen ${ }^{31}$ ), Epist. 41 being the first letter of Alcuin's to celebrate Charlemagne as David. ${ }^{32}$ This phenomenon only spread at court after Alcuin had won Charlemagne's approval. ${ }^{33}$ This supports the theory that Alcuin was the introducer of this practice of using pseudonyms. ${ }^{34}$ Because of its frequent occurrence in Alcuin's epistles, the name David has attracted the most attention out of all pseudonyms for Charlemagne. It has been stated above that the name David has a strong spiritual connotation in Alcuin's correspondence. This can be confirmed by looking at some selected epistles in which the names of the two Biblical kings David and Solomon are applied to Charlemagne and/or to his newly crowned son, Charles the Younger. ${ }^{35}$ The analysis sheds light on the ruler's status and brings more clarity to the question of what place Alcuin allocated to the Frankish realm within God's providential plan. Overall, the writings bear out to some extent Arquillière's ${ }^{36}$ argument that Charlemagne, by taking on the mission to implement pax and iustitia, could lend to these concepts the religious contents they had adopted since Merovingian times under the so-called Augustinisme politique. Indeed, a connection is revealed between Alcuin's use of the notions of pax and iustitia and his reference to the Biblical kings. Moreover, in one case, an intriguing association is made between Charlemagne as King David and the civitas Dei.

It makes sense to start with Epist. 41, addressed to the king, where Alcuin for the first time draws a parallel between Charlemagne and King David. ${ }^{37}$ After explaining that he had received from the visitor Candidus the king's gift and salutation as well as the good news about the king's prosperity and diligence in 
studying the Catholic faith, Alcuin introduces the parallel right away. He first outlines the most striking features of Charlemagne as a ruler and his realm. After this, he explains that in a similar manner King David, elected and loved by God, ${ }^{38}$ conquered surrounding tribes and instructed them in the true faith and in the law of God. Alcuin begins as follows: "Blessed is the nation, whose master is their God: and blessed is the people that is exalted by a ruler of such a kind and fortified by such a public preacher; and each of both: the sword of triumphal power vibrates in the right hand and the trumpet of Catholic preaching resounds on the tongue." ${ }^{39}$ Then he adds: "In such a way also David, once king of a preceding people, was elected by God and loved by God and, as an excellent psalmist of Israel subjecting by his victorious sword races from all directions, emerged among the people as a chosen preacher of the law of God." ${ }^{40}$ It thus appears that Charlemagne and David are both kings of a people that have God as their leader. ${ }^{41}$ Hence, these rulers have not only the function of expanding their realm politically but also of spreading the Word of God. Alcuin presents Charlemagne and David as two kings who are ruling in accordance with the will of God, implementing the law of God. This comparison is followed by a second parallel, this time with Christ. Alcuin writes:

By the select noble origin of his [David's] sons to the well-being of the world, Christ blossomed from a twig as a flower of the open field and narrow valleys, who, a little while ago in those times and of the same name, virtue and faith, authorised King David as a ruler and teacher for his people.

Under his supernal shadow the Christian people rests peacefully, and terrifying it stands out from the pagan races everywhere. ${ }^{42}$

Alcuin unambiguously links Charlemagne and David with Christ by indicating that Christ is of the house of David. Alcuin uses the formula populus Christianus ("Christian people") to refer to Christ's heavenly realm. This term (as established by Ganshof and previous scholars ${ }^{43}$ ) is one of the key terms Alcuin employs to denote Charlemagne's realm shortly before the imperial coronation. It sets Charlemagne's empire apart from all previous Christian 'states' on earth.

Epist. 217, directed to King Charles the Younger, reinforces Alcuin's argument that Charlemagne and his successors are higher in rank than all earlier Christian rulers. ${ }^{44}$ The address introduces the motivation of the letter, which is the celebration of the royal coronation of Charles the Younger. Charlemagne is mentioned as David when Alcuin states that this coronation took place with his consent. ${ }^{45}$ Alcuin first expresses his happiness about the young king's newly acquired title and power, and then his hopes that the young ruler may be of service to many peoples as well as to the Christian 'church'. ${ }^{46}$ In the following passage, Alcuin points out that, in order for his wishes to come true, Charles the Younger needs to implement justice and bring about forbearance - the two fundamental elements, according to Solomon (son and successor of King David, as Charles was to Charlemagne), which constitute a God-placating rule. Alcuin declares: "From there, most beloved son, through your actions, create justice and forbearance among the Christian people; because these are the ones, since Solomon is 
attesting it, that exalt the official seat of a realm, and bring about a laudable and God-placating power." ${ }^{47}$ Alcuin uses the Biblical words of Solomon from the Old Testament in order to identify the essential goals of a ruler who executes God's commands. Moreover, he again chooses the term populus Christianus, which Alcuin applies to Christ's heavenly realm in Epist. 41. By drawing a parallel between Charles the Younger and Solomon, Alcuin presents a role model of a true Christian king. But shortly afterwards, Alcuin even admits: "It is not for you to look for examples at length. For in the house in which you were brought up, you have the best examples of all goodness." 48 Alcuin advises Charles the Younger to follow the example of his father Charlemagne by saying:

And trust that the benediction follows you, you most assured of your wellknown, excellent father, most noble through every glory, of the ruler and emperor of the Christian people, as long as God grants it, if you make an effort to imitate the morals of his nobility as well as piety and all modesty; and to earn most fully the forbearance of the master of the house, which is better than the glory of all time. ${ }^{49}$

Charlemagne is here described as rector et imperator populi christiani ("ruler and emperor of the Christian people").$^{50}$

In Epist. 177, ${ }^{51}$ where Alcuin begs Charlemagne to intervene in favour of Pope Leo III, Alcuin once more uses the pseudonym David. ${ }^{52}$ Before announcing the urgency of the situation in Rome and before pointing out that Charlemagne is the only candidate entitled to direct the judicial investigation, Alcuin expresses warm approval and admiration for the king. In these lines, Alcuin first addresses Charlemagne as decus populi christiani ("glory of the Christian people"). Afterwards he writes: "With all these vows it is necessary to exalt your blessedness, to assist it by intercessions, until the Christian empire is preserved by your success, the Catholic faith is defended, the rule of justice becomes known to all." 53 Apart from the military defence of the Christianum imperium ("Christian empire") and the protection of the Catholic faith, Alcuin cites the spread of the principles of justice as a third main responsibility of the Christian ruler - which in the course of the letter gains in importance when Alcuin expands on the judicial matter and portrays Charlemagne as the only man alive endowed with the power to execute what pleases God. The acts of performing justice and making law are repeated further down in the epistle among the other duties of the Christian ruler. As a reward for accomplishing these tasks, Alcuin maintains, God will bless Charlemagne's sons richly and preserve the royal throne for all of his descendants, just as he did with his favourite, King David. Alcuin contends: "[...] and a rich blessing should grow through your good deeds for the most illustrious sons of your nobility; just as it is read that, through the sanctity of your only homonym, David, of the king most loved by God, the power of the royal throne was preserved for all of his descendants." 54

In his De civitate Dei, Augustine had reasoned that true justice in a 'state' can only be achieved if God is the commander of all people and all of them 
obey Him. ${ }^{55}$ This, Augustine believes, cannot possibly be realised on earth, wherefore a worldly civitas Dei becomes inconceivable. However, Epist. 41, Epist. 217 and Epist. 177 suggest that Alcuin thinks otherwise as far as the Carolingian 'state' is concerned. ${ }^{56}$ Epist. 41 depicts Charlemagne as well as Christ as descendants of King David. In Epist. 41, populus Christianus occurs with reference to the people of the kingdom of Christ, while in Epist. 217 and Epist. 177, the same expression stands for both the people of Charles the Younger and the people of Charlemagne. Epist. 41 contains a phrase that is tremendously telling in terms of the depth of Alcuin's political statement in these epistles dealing with the status of the Carolingians as Christian rulers. Alcuin notes: "Blessed is the nation, whose master is their God." ${ }^{57}$ This comment makes the Carolingian 'state' meet Augustine's prime condition for being a godly 'state' on earth. It also takes the existence of implicit Augustinian ${ }^{58}$ elements in Alcuin's correspondence to a new level; it now stands to reason that Alcuin has well understood the conditions set by Augustine in the De civitate Dei under which a 'state' might be recognised as worldly or godly. His programme is evidently to show by argument that the Carolingians are Christian rulers able to lead a people to the furthest extent possible under the divine commandments of the Christian God. Accordingly, Alcuin holds that the conditions of iustitia and pax that prevail within the Carolingian 'state' are not the worldly forms of these concepts, but amount to the justice and peace granted to the Christian ruler and his Christian people by God. Epist. 217 argues that, in order for King Charles the Younger to be a successful ruler, gain the blessing of God and eventually become a citizen of the Kingdom of God, he first and foremost has to bring about justice among the Christian people along with forbearance. Only if these two conditions are reached - as stated by Solomon - will the ruler have gained an authority that is pleasing to God. In Epist. 177, where Alcuin communicates to Charlemagne the plan of action to be taken to restore the Holy See, Alcuin introduces the proclamation of the rules of justice among the nations as a further responsibility of the Christian ruler. Last but not least, in Epist. 174, written to Charlemagne and addressing him as King David in early summer of 799, Alcuin says: "You are the judge of the crimes, you are the guide of the erring" (Tu vindex scelerum, tu rector errantium) ${ }^{59}$

When considering the occurrences of pax in Alcuin's correspondence, one finds that there is again no doubt as to the quality of this concept; the peace within the Carolingian realm is the peace given by the Christian God. ${ }^{60}$ The most significant reference to peace can be found right at the beginning of Epist. 198, after Alcuin greets Charlemagne as King David. Alcuin says:

While I know that the glorious sublimity of your power does not rule over a Jerusalem ready to be destroyed by the Chaldean fires, but guides and governs the city of eternal peace built with the precious blood of Christ, whose [the city's] living stones are kept together by the glue of love and whose walls of heavenly structure, made out of various gems of virtues, rise up to the sky $[\ldots]^{61}$ 
Alcuin terms Charlemagne's 'state' perpetuae pacis civitas ("city of eternal peace"), which comes very close to a city of God realised on earth. In any case, in this passage Charlemagne's civitas is shown to be clearly superior to Old Testament Jerusalem, which is referred to as condemned to certain destruction. ${ }^{62}$ This implies that Alcuin thinks of Charlemagne's reign as ranking higher than that of the Old Testament kings. Alcuin considers himself to be a member of Charlemagne's perpetuae pacis civitas when he asserts: "[...] I, some insignificant part of this city [...]" (ego, minima quaedam huius civitatis portio) ${ }^{63}$

This is not the only case where Alcuin alludes to the civitas Dei when talking about the Carolingian 'state'. Like Epist. 198, Epist. 139 also contains both a powerful link between Charlemagne and the Old Testament kings David and Solomon and a direct association of Charlemagne's realm with the civitas Dei. ${ }^{64}$ The epistle is addressed to Paulinus II of Aquileia, who was greatly concerned with the unity of Catholic doctrine. From 792 onwards, he took action against Adoptionism (taught by, among others, the Spanish bishops Felix of Urgel and Elipandus of Toledo) by writing a book that was sent to Spain and taking part in the councils of Regensburg (792), Frankfurt (794) and Cividale (796/797). Besides his involvement against heresy, he elaborated on the doctrine of the Holy Trinity. Epist. 139 conveys Alcuin's admiration and respect for Paulinus' efforts and provides encouragement and support. While the letter includes some notes on the Trinity, it first and foremost calls attention to the prominence of Paulinus as an advocate of the integrity of Catholicism. In the conclusion of Epist. 139, Paulinus is even represented as the primary defender of the Catholic 'church', on whose victory the entire Christian community, including its leader, relies. In these lines, Paulinus appears as the guardian of the doors of the civitas Dei as well as the holder of the clavis Daviticae potentiae ("key of David's power"). Immediately afterwards, Alcuin declares that he himself will pray, while waiting together with King David in the safest tower of the civitas, until Paulinus has succeeded against the heretics. In the following paragraph, Charlemagne is then paralleled with King Solomon. The passage is as follows:

But it is your task, excellent shepherd of the flock and guardian of the doors of the city of God, who hold the key of David's power in your right hand, and keep hidden five most limpid stones in your left, to crush with one blow of truth all those Philistines ${ }^{65}$ blaspheming in the name of the most arrogant Goliath against the army of the living God.

It is our task together with Moses $^{66}$ with hands elevated towards the sky, to assist you with prayers of humility and to watch with David in the safest tower of the city, until the look-out, calling from the high top of the mountain, announces to us your victory.

The eyes of all who wish to hear anything of your exceptionally rich heavenly speech are directed towards you: and they observe that through you the coldest stones of the hailstorm, which are not afraid of striking the crown of the wisest Solomon, are melted very swiftly by the burning sun of wisdom. ${ }^{67}$ 
Charlemagne's 'state' is pictured as the perfect Christian community of the civitas Dei on earth, which is defended by Paulinus from ungodly outside attackers, the heretics. ${ }^{68}$ According to Alcuin, he is the man who knows best the doctrine of Catholic faith and is therefore the legitimate protector of the power of the ruler of the civitas Dei, Charlemagne (in the person of an Old Testament king). Alcuin's statement that he himself is situated in the fortress of the city together with King David and the subsequent comment that the assaulters would not even stop before the king, the "wisest Solomon," are sure indications that Charlemagne is meant as the ruler of the civitas Dei.

That Alcuin presents the Carolingians and their 'state' as an exception - i.e. the rulers as superior in Christian morals to the most respectable Christian Roman emperors and their 'state' as ranking higher than Old Testament Jerusalem - would have as a logical consequence that Alcuin thinks of the Frankish nation as a people chosen by God. In her article "The Franks as the New Israel? Education for an Identity from Pippin to Charlemagne," Garrison takes a critical look at the evolution of the concept of election by God among the Franks. ${ }^{69}$ She traces its origin back to the Bible and defines the method - typological thought - necessary for exploring the idea of election by God. Garrison shows that the Carolingians, from the mid-eighth century onward, increasingly made typological comparisons. ${ }^{70}$ The essence of Garrison's argument is that the first authors to create the most expressive representations of the Carolingians as the people of God were non-Franks: the popes (Zacharias, Stephen II, Leo III) and then the insular emigrés in the mid-780s and 790s. ${ }^{71}$ The typological comparisons examined by Garrison also include Old Testament parallels to the kings David and Solomon. ${ }^{72}$ Towards the end of the article, Alcuin is discussed as one of the most prominent devisers of typological images. ${ }^{73}$ Garrison maintains that by the 790s, the Bible had become authoritative to the extent that Biblical law could be applied to the Franks (as claimed in the prologue of the Admonitio Generalis of 789), and Charlemagne could not only be equated to King David but even be named David. In this context, Garrison mentions Alcuin's Epist. 229, a very late piece of correspondence with the emperor. ${ }^{74}$ She explains: "In 801, after Charlemagne had been addressed as David for the better part of a decade, and after Alcuin and Theodulf had likened his wisdom to Solomon's, Alcuin dared to fuse the beata gens of the Old Testament with the blessed res publica of the famous Platonic proverb that asserted that 'states' would be blessed if their kings were philosophers or philosophers were their kings." 75 Afterward, the relevant passage from Epist. 229 is quoted:

Blessed is the nation, for which divine clemency provided such a pious and prudent ruler.

Happy is the people, which is led by a wise and pious leader; just as one can read in the well-known Platonic proverb which says that realms are happy, if philosophers, that is lovers of wisdom, have royal power, or if kings study philosophy.

Since nothing in this world can be compared to wisdom. [...]

Since it is solely true of wisdom that it will bring about eternally blessed days. ${ }^{76}$ 
That Alcuin prefaces the proverb with the phrases beata gens and felix populus, Garrison observes, clearly connects Alcuin's passage with the two verses (Beata gens cuius est Dominus Deus eius ${ }^{77}$ and beatus populus cuius Dominus Deus eius ${ }^{78}$ ) of Psalms 32 and 143, referring to the blessed nation of Israel. ${ }^{79}$ Garrison rightly says that in Epist. 229 Alcuin intimates that the Carolingians under Charlemagne will achieve the same eternal blessedness as the chosen people of the Old Testament. She correctly stresses: "[...] the traditional exegesis of beata gens interpreted the beata gens as the heavenly Jerusalem or else the Christian people generally, but never as approximating any secular political entity as Alcuin seems to do." Here Augustine's Enarrationes in psalmos $I-L$ appear as a reference among others. ${ }^{80}$ But then a statement made at the very end of the text attenuates Garrison's argument. She points out that the cited paragraph from Epist. 229 introduces Alcuin's request for retirement and thus was composed by Alcuin for the explicit purpose of flattering the emperor. Her words are: "Thus, what appears to be the grandest equation of all between the Franks and the chosen people is flattery addressed only to Charlemagne." ${ }^{81}$

However, Garrison overlooks the much earlier letter Epist. 41, which first gives the pseudonym David to the king. ${ }^{82}$ This writing testifies that Alcuin already made the equation of Charlemagne's people with the people of God after the king had taken up residence at Aachen in 794. This epistle does not contain any appeal on Alcuin's part comparable to that made in Epist. 229. Yet the wording here is even closer to that of the verses of the Psalms, when it says: "Beata gens, cuius est dominus Deus eorum: et beatus populus tali rectore exaltatus et tali praedicatore munitus [...]." 83 The lines include the expressions beata gens as well as beatus populus. What is more, the following sentence begins with: "Ita et David olim praecedentis populi rex a Deo electus et Deo dilectus [...]." ${ }^{44}$ This rather suggests that the passage alluding to the Psalms refers directly to Charlemagne's realm since it is only after that that the comparison is made to the former "people of God" ruled by King David.

A letter already mentioned in the first chapter of Part II, dealing specifically with the problems and complexities of subjugation, Christianisation and the process of conversion (inter alia exhorting the king to go about conversion using more lenient means), further clarifies the question of the "chosen" status of the Frankish people: in Epist. 110, written to Charlemagne (and to "the preachers of the words of the holy God" ${ }^{15}$ ), it becomes evident that Alcuin sees the Carolingian 'state' more than anything else as a godly realm. ${ }^{86}$ The address to the king discloses that Alcuin wishes Charlemagne success in his political duties only as far as they agree with the doctrine of the Catholic 'church'. The letter commences with:

The humble young son of the holy mother 'church', Albinus, wishes to the most excellent master Charles, devoted to every honour of Christ, king of Germania, Gaul and Italy, and to the public preachers of the words of the holy God, every blessing towards eternal glory in Christ. ${ }^{87}$ 
The following lines emphasise even more Charlemagne's function as an executor of God's plan. ${ }^{88}$ Alcuin expresses his gratitude towards God, who granted Charlemagne the strong will to expand the Christianitatis regnum ("realm of Christianity") - which indicates that he is not yet emperor - by military subjugation and Christianisation. ${ }^{89}$ Alcuin's words are:

Glory and praise to God the Father and Our Lord Jesus Christ, since He extended the realm of Christianity as well as the knowledge of the true God thanks to the Holy Spirit - through the devotion and service of your holy faith and good will - and led most peoples far and wide away from their errors of impiety onto the road of truth..$^{90}$

Another significant piece of information is contained in these lines; Alcuin uses the formulation plurimi populi ("most peoples") when he talks about the peoples who have been conquered and brought onto the right path in terms of faith. This expresses indirectly that there must be a certain number of people who are disloyal and therefore - at least for the time being - not part of the elect Christian community. Elsewhere in Epist. 110 Alcuin confirms: "But since election with regard to those seems not yet to have been divine, many of them still persist to the worst in the lowness of a condemnable lifestyle together with the devil." ${ }^{91}$ The chosen status of Charlemagne's subject peoples is hence restricted to those who are thoroughly converted. To these elect, however - in opposition to Augustinian thought - eternal life is guaranteed by their perfected Christian faith:

What glory will there be for you, most blessed king, on the day of eternal retribution, when all these, who have been converted through your good care from the culture of idolatry to the recognition of the true God, will follow you before the tribunal of Our Lord Jesus Christ, as you stand among the blessed kind, and when from all these the price of eternal blessedness is enriched. ${ }^{92}$

\section{Alcuin's use of Augustinian vocabulary}

In the following section, which is concerned with Alcuin's language and terminology, I trace a set of Augustinian concepts in Alcuin's source material (mostly in texts already discussed earlier) and explore Alcuin's use of words relating to them. The selected Augustinian concepts, terms and expressions are the political terms civitas Dei, imperium and gentes (around which regna terrarum and the expressions subicere, subdere and subiugare/iugum are clustered); the expression in cuius potestate sunt omnia regna terrarum as well as the concept of dispensatio. It is revealed how in linguistic terms Alcuin imitated the Augustinian political discourse. This does not mean, however, that Alcuin did not have his own political agenda. On the contrary, the language and terminology Alcuin availed himself of were given a new political meaning. E. Auerbach was led to similar conclusions in his linguistic analysis of Einhard's Vita Karoli Magni, where he established agreements in form with Suetonius' biography of Augustus. ${ }^{93}$ He examined 
two passages that had no overt political content like the extracts under discussion here but instead contained descriptions of the relationship of the emperors (Charlemagne and Augustus) with their respective relatives. ${ }^{94}$ While the portraits of these emperors were entirely different (Charlemagne was pictured as an impulsive sentimentalist with little self-control but was praised for his pietas; Augustus appeared as a contained and stern figure who suffered from the misconduct of his descendants and punished them severely), Auerbach found correspondences between these passages in terms of style, syntax and vocabulary. Auerbach's method of interpretation therefore allows the identification of coherences at an additional level of the texts.

\section{Civitas Dei}

In the third chapter of Part I on Augustine and the De civitate Dei, I identified five Latin expressions that come close to the English word "state" and which appear in the De civitate Dei, and I explained their use by Augustine. At the heart is civitas, which Augustine - as he himself maintains in the first chapter of Book $\mathrm{XI}^{95}$ - very consciously selected as the key term to denote the city of God (and the earthly city) with which his apology is concerned. ${ }^{96}$ When searching for the word combination civitas Dei in Alcuin's texts, few results are found. One of them (in Epist. 139), where the civitas Dei is directly associated with the realm of Charlemagne, who is typified by King David, has already been discussed. Two further occurrences are revealing when taken as a pair. They appear in Epist. 76 and Epist. 89.

Epist. 76 is a letter to Bishop Remedius of the East-Alpine diocese of Chur ${ }^{97}$ (the recipient is addressed as Remedius episcopus ${ }^{98}$ ), seemingly a friend stationed far away from Alcuin (the letter says "Love between friends is certainly better than gold and loyalty between distant ones more precious than jewels $[\ldots]]^{\prime 99}$ ). The letter has a motivational purpose. ${ }^{100}$ It seems that the bishop has been well and successful (at the beginning Alcuin writes "[...] we are very glad about your prosperity $[\ldots]]^{\prime 101}$ ), and now Alcuin encourages him further by observing that God will reward him by receiving him into his eternal realm:

You, most diligently pursue what is yours and multiply the received talents of godly ${ }^{102}$ wealth $[\ldots]$.

Now is the time to work, then the time to rest; now the time to earn, then the time to repay.

Act as you should be, so that what you wish may come to you.

Love the one who loves you, until you may deserve to arrive at the most blessed seat of the well-known one and say: "Just as we have heard, so we have also seen in the realm of our God", in which there is complete happiness and no disturbance, the greatest rest and everlasting blessedness. ${ }^{103}$

The quotation containing the word civitas Dei is drawn from a verse of Psalm 48. ${ }^{104}$ 
Epist. 89 is directed to a bishop in England ${ }^{105}$ who remains unnamed (the salutatory address is Pro pontifici ill. ${ }^{106}$ ). He is asked to pass this writing on to another bishop in England. ${ }^{107}$ Again, the text gives the impression of being a letter of encouragement. At first the bishop is praised, inter alia because of his concern for the well-being of his fatherland and its inhabitants. ${ }^{108}$ Then Alcuin declares that it is the bishop's work, reward, praise and glory that he can preach the word of God with great confidence. ${ }^{109}$ Alcuin reminds him not to be fearful of tongues that are talking idly and trying to ignite flames together with a rich man clothed in purple (i.e. of high office); ${ }^{110}$ this must be an exhortation to fight heresy. Instead, Alcuin urges the addressed bishop, and the other bishop to whom the message was supposed to be communicated, to get ready to join God in eternity, just as another recently deceased devout bishop had done. ${ }^{111}$ He appeals to them:

Cover with your apostolic clothes the road for Christ's donkey, in order that it [the donkey], carrying the famous one, may proceed towards Jerusalem on even foot, lest it [Jerusalem] be destroyed by the Roman armed forces, but be continuously rebuilt by the souls of the saints, to there lead me, not confident about any rewards, away with you, through the prayers of your piety giving divine grace, where we together may say: "Just as we have heard, so we have also seen in the realm of our God, glorious things are told about you; the realm of the Lord is eternal peace to me through your virtue and abundance of all joy in your towers". ${ }^{112}$

It is not known from where exactly Alcuin draws the last quoted sentence; it could be his own composition or the phrase of another author. Either way, it is clear that the quotation once again starts with the beginning of verse 9 of Psalm $48 .{ }^{113}$ The following part, "[...] gloriosa dicta sunt de te [...]," surprisingly belongs to an entirely different Psalm. ${ }^{114}$ The rest of the quotation can unfortunately not be identified, except for the last words "[...] in turribus tuis," which once more allude to Psalm 48. ${ }^{115}$

What is intriguing is that Alcuin's quotations "Sicut audivimus, ita et vidimus in civitate Dei nostri" (and the remaining part of verse 9) from Psalm 48 and "gloriosa dicta sunt de te" from Psalm 87 in Epist. 76 and Epist. 89 both appear (next to another short excerpt from a Psalm which contains the term civitas Dei $\left.{ }^{116}\right)$ in the first chapter of Book $\mathrm{XI}^{117}$ of Augustine's De civitate Dei. This chapter is, as has been said, highly revealing regarding Augustine's choice of subject for his oeuvre and choice of terminology. ${ }^{118}$ Here, Augustine refers his use of civitas for the city of God back to the (Latin) Bible by saying that it is from these Psalms that we have proof of the existence of a civitas Dei; and this evidence gives Augustine the motivation for composing his work. ${ }^{119}$ Augustine adds that, having selected and given justification for the subject matter of his book, he is aware that in the following text he owes to the reader a detailed description of the roots, evolvement and final state of the city of God and of the earthly city. ${ }^{120}$ The purpose for which Alcuin avails himself of the phrase civitas Dei is here fundamentally different from that of Epist. 139, where 
Charlemagne's realm, as a 'state' perfect in its Christian principles, is equated with the civitas Dei. Epist. 76 and Epist. 89, at first glance, do not seem to be letters of formal notice and of official political weight (which does not mean, however, that they are politically insignificant). Alcuin's primary concern in the letters to these bishops is to give support, confidence and hope. In Epist. 89, Alcuin cordially brings the bishop's main commitment - to preach the word of God with conviction and assertiveness - to the addressee's attention. Epist. 76 explicitly stresses the importance of loyalty and friendship between distant associates. Both texts display the workings of politics under Charlemagne; the success of the ruling elite was dependent on consensus, cooperation, good will and on inspiring loyalty in each other. ${ }^{121}$ The hope expressed at the end of each letter in the promise of eternal happiness for the members of the civitas Dei indicates that Alcuin not only used this concept politically when drawing a parallel to Carolingian rule, but also included it in letters to his peers. This shows that Alcuin wanted to spread the Augustinian idea of the civitas Dei among all his acquaintances and wished them to participate in it. Furthermore, Alcuin evidently tried to win them over to the political discourse he had established among Charlemagne's inner circle.

\section{Dispensatio}

Another key term in Augustine's historiography that features in Alcuin's material is dispensatio. The concept of dispensatio/dispensator/dispensare appears in a number of places in Alcuin's written material, and in almost all the meanings attributable to Augustine, except in its composite form dispensatio temporalis. However, Alcuin is also acquainted with the regular use of the noun dispensatio/oiкоvонí as it occurs in the New Testament, where one of its two principal meanings is "God's plan of salvation" (in which also the concept of providentia is incorporated). In the second paragraph of Epist. 196, for example, Alcuin emphasises that there is no other knowledge except the one which heavenly grace distributed to the human race according to the dispensation of divine providence. ${ }^{122}$ Furthermore, dispensatio is found in its literal sense of "(house) management," "stewardship" as it corresponds to the original meaning of the Greek оiкоvонí; in Epist. 111, directed to Megenfried (treasurer of the royal court ${ }^{123}$ ), Alcuin writes: "[...] the management of the vines of Christ, that is of the 'churches' of Christ.". 24 As far as Augustine's influence is concerned, there is clear evidence of Alcuin's familiarity with the idea of the dispensatio of God as a term for the working of God's plans, which are unfathomable to men, applied in connection with the historical economy of salvation. One example can be found at the end of Epist. 159:

However, God's forbearance, by aiding and steering our thoughts and desires, may grant us, since the wish has been prayed for, to come together in order to search for the salvation of everlasting prosperity, in accordance with the convenience of His [God's] attribution [...]. ${ }^{125}$ 
Augustine's more general use of dispensatio in order to define any kind of events relevant to eschatology can also be found in Alcuin's writing. Towards the end of Epist. 307, Alcuin explains that the entire Passion of Christ happened through the dispensation of godly love/dutifulness. Alcuin writes:

Whatever can be read that was done towards the suffering of our Lord, the Saviour, either through devilish spite or through Jewish ungodliness, this was all the dispensation of divine piety $[\ldots] .{ }^{126}$

In this sentence, the dispensation is effected by God in order that the Passion of Christ can be completed. In another letter from the summer of 800, Epist. 200, Alcuin conveys his firm belief that it was by divine dispensation that he had been summoned to Charlemagne's kingdom. ${ }^{127}$ It says:

For the means of his service, at the command of divine dispensation, as I believe, I, having been called, came to Charles, the glorious leader and king of this realm, who is to be named with all honour, $[\ldots] .{ }^{128}$

However, as for the dispensatio of Christ, Alcuin deviates from Augustine in that - in his Commentaria in sancti Iohannis Evangelium - he makes frequent use of the traditional denomination of Christ's act of redemption as dispensatio. In two passages, Alcuin unambiguously presents Christ in the function of dispensator or as the issuer of dispensatio. First Alcuin maintains:

Thus, the first dispensation of our Lord Jesus Christ was remedial, not judicial; for if He had first come in order to judge, He would have found no one to whom He could have given the rewards of justice. ${ }^{129}$

Later on he claims:

Because whatever has been done there with regard to the distribution of human salvation, the one Christ achieved all this, the only proper and perfect Son of God $[\ldots] \cdot{ }^{130}$

The formula of verbi dispensare or dispensatio verbi "(the) spreading (of) the word of God (orally or in writing)," which is recurrent in Augustine's writing, is represented in Alcuin's texts as well. In a letter to Charlemagne, Epist. 136, Alcuin says when quoting Luke ${ }^{131}$ :

And somewhat later: "Who listens to you, listens to me; and who scorns you, scorns me; and who scorns me, scorns the one who sent me", and other things, which are read there about the spreading of God's words. ${ }^{132}$

Furthermore, the noun dispensator occurs in Alcuin's work both with reference to God as well as with reference to persons who perform their duties in a manner 
loyal to God. Examples of both instances can be found in Epist. 111 to the treasurer Megenfried. In one instance it says:

There is one who receives the gift of preaching; another that of wisdom; another that of wealth; another that of any aid, a certain other perhaps the gift of some unknown skill from God, the dispenser of all these goods. ${ }^{133}$

In another instance Alcuin writes:

And you, most faithful dispenser of treasures and preserver of resolutions and devoted assistant, firmly do his [Charlemagne's] will. ${ }^{134}$

Here, it seems that the man Megenfried in his function as a loyal treasurer of Charlemagne, the representative of God in Francia, has also earned the title of a dispensator (although of course limited to the treasures). Finally, there is evidence in the sources that Alcuin in fact used forms of the verb dispensare (in Augustine's sense), from which Augustine typically derived the nouns dispensator and dispensatio. Alcuin relates in his Vita Willibrordi archiepiscopi Traiectensis ${ }^{135}$ :

But in order that the truth of the dream, while God is dispensing, might be fulfilled, which the mother [of Willibrord] testifies to have once seen regarding him [Willibrord], ${ }^{136}$ he, conscious of his will, though until then ignorant of the divine dispensation, thought to sail to these parts and, if it was God's will, to enlighten with the brightest light of evangelical preaching peoples slumbering in deep faithlessness. ${ }^{137}$

The representation of dispensatio/dispensator/dispensare in the above passages suggests that Alcuin's use of the concept was both wide-ranging and similar to the terminology Augustine was familiar with. Having thoroughly discussed Augustine's understanding in the third chapter of Part I, and having explored Alcuin's conception above, it is time to look at the terminology dispensatio/dispensator/dispensare in a more revealing context. In the oeuvres of Alcuin and Augustine, the noun dispensatio and the verb dispensare emerge in passages where the dispensatio ("dispensation/distribution," "attribution/assignment") of God decides on the election of earthly governors or representatives (dispensatores). ${ }^{138}$

First of all (and of less concern in terms of content), there is Epist. 272, in which Alcuin reports that God assigned him as the leader of a congregation consecrated to John the Baptist. Epist. 272 starts with the words:

For the first congregation, which I was given to govern by God dispensing, was consecrated to the blessed John the Baptist. ${ }^{139}$

Epist. 174 is part of the correspondence written after the assault on Pope Leo III on 25 April $799,{ }^{140}$ in which Alcuin repeatedly indicated to the king that he, 
bearing the title of patricius Romanorum, was responsible for the defensio ecclesiae Romanae as well as the welfare of the pope, and was the one authority who needed to act at this time of turbulence. ${ }^{141}$ Alcuin wrote this letter to the king in early summer $799 .{ }^{142}$ The text evaluates the current state of affairs and the three supreme Christian powers on earth - that of the pope, the Byzantine emperor and Charlemagne. The papal authority is discussed first:

[...] it is the apostolic sublimity, which is accustomed to govern the seat of the blessed Peter, prince of the apostles, in the function of a representative; but what was done to him, who used to be the ruler of the aforementioned seat, your venerable kindness cared to make known to me. ${ }^{143}$

The above passage shows that Alcuin directs Charlemagne's attention to the present crisis and to the pope's incapacity for office. Later on, Alcuin expands on the Byzantine imperial dignity:

The other one is the imperial dignity and the secular power of the second Rome; everywhere rumour is growing recounting how impiously the governor of the empire of that one was deposed, not by foreigners, but by his own people and fellow citizens. ${ }^{144}$

Here, Alcuin points to the Byzantine Emperor Constantine VI, having equally been removed from office by his own mother and co-regent Irene, who became the sole ruler of the empire in August 797, after having blinded her son. ${ }^{145}$ Thus, in second place after the pope, Alcuin names the authority of the Byzantine ruler and refers to him as the "imperial dignity" and the "secular power of the second Rome," while in the following Charlemagne's status is defined as "regal dignity." All the more surprising are Alcuin's remaining words regarding the influence of the king:

The third is the regal dignity, for which the dispensation of our Lord Jesus Christ set you in order as a ruler over the Christian people, since you exceed the other aforementioned dignities in power, being brighter in wisdom, being more sublime in your dignity of rulership.

See, in you alone lies inclined the entire salvation of the 'churches' of Christ.

You are the judge of the crimes, you are the guide of the erring, you are the consoler of the sad, you are the exaltation of the good. ${ }^{146}$

In Epist. 174, Alcuin assigns greater potentia ("power"), sapientia ("wisdom") and regni dignitas ("dignity of rulership") to the king than to the pope and the Byzantine emperor, even though his title alone would place him clearly below the other authorities. The aim of such representation is to show that by God's will, through the influence and reputation gained, Charlemagne has already risen above the status of king. Since the pope and the Byzantine emperor as Christian powers 
are temporarily suspended, and Charlemagne is the only power worthy of remaining in office, he is at this very moment ordained to take charge of the protection of the 'church'. A few lines down, Alcuin warns Charlemagne of the seriousness of the situation by quoting from the Sermon on Apocalyptic Prophecy. ${ }^{147}$ In the above excerpt, describing the authority of Charlemagne, Alcuin avails himself of the noun dispensatio to refer to the working of God's plans. Alcuin uses dispensatio neither in the preceding examination of the papal dignity of Pope Leo III nor in the evaluation of the Byzantine imperial dignity of Constantine VI, but solely with reference to Charlemagne; he aims to draw attention to God's salvific work as underlying Charlemagne's extraordinary power and capacity for rulership. Alcuin confirms Charlemagne's chosen status even before his elevation to his imperial one. ${ }^{148}$

In the second chapter of Part I, which was concerned with the Roman 'state' and Augustine's stance on worldly rule, Chapters 25 and 26 of Book V of the work De civitate Dei emerged as most crucial in terms of divulging Augustine's evaluation of Christian earthly rulership. These chapters are dedicated to the personalities and achievements of Constantine I and Theodosius I, the two Christian Roman emperors whose influence was decisive for the consolidation of the Christian 'church'. Furthermore, it was also observed in Part I that the Christian Roman empire, and in particular the Christian emperors Constantine I and Theodosius I, are less rigorously criticised by Augustine. Indeed, they are praised, albeit within reasonable limits, and when discussing Christian worldly 'states' Augustine concludes that " $[\ldots]$ the reward for which deeds is eternal happiness, whose giver is God to the truly pious alone." ${ }^{\prime 149}$ This conclusion is made in Chapter 26, which expounds on the efforts and accomplishments of Emperor Theodosius I. Immediately following this judgment, there is a sentence explaining God's dispensation of earthly life and earthly goods - and here Augustine emphasises that among these goods, which are significantly assigned to both good and evil men, there is in particular the gift of rulership, which God distributes for the control of the times. Augustine formulates:

[...] among them [the other things of this life] there is also whatever size of power, which He dispenses for the control of the times. ${ }^{150}$

It can be assumed that Augustine's use of the verb dispensare in this particular location of the De civitate Dei (where it becomes apparent that to Augustine the Christian Roman emperors hold a superior position among earthly authorities) inspired Alcuin to apply it in a formal letter to the king where he takes a clear stand on the distribution of power in the actual political world.

Everything considered, it is fair to say that the concept of dispensatio/dispensator/dispensare appears in all the meanings attributable to Augustine - save in its composite form dispensatio temporalis. However, as opposed to Augustine, Alcuin does make regular use of the traditional denomination of Christ's act of redemption as dispensatio. Still, in Alcuin's and Augustine's writing, the noun dispensatio and the verb dispensare can evidently be found in crucial passages 
where the dispensatio ("dispensation/distribution," "attribution/assignment") of God chooses Christian earthly governors or representatives (dispensatores).

\section{Imperium and gentes}

Furthermore, Alcuin's use of the political terms imperium and gentes, particularly in one of his Epistolae ${ }^{151}$ to Charlemagne and in his carmen $^{152}$ about the city of York, seems striking. They are two opposed terms around which the following words are found being grouped in order to heighten their polarity: subicere ("to subject"), subdere ("to subdue"), iugum ("yoke") and regna terrarum ("realms of the earth"). The word imperium, which holds the meanings "supreme power (of Roman emperors)," "(military) command," "rule," "empire" and "world power," is a derivative of imperare ("command," "rule (over)") 153 and in the Classical Roman Period commonly carries a connotation that refers to the military. ${ }^{154}$

Gentes (pl.) translates as "races," "tribes," "nations" and is the Latin equivalent of the Greek $\varepsilon \theta v \eta$ (pl.). ${ }^{155}$ In contrast to the Greek term $\beta \alpha \alpha \beta \beta \alpha \rho$, gentes does not have an overtone of "being uncivilised," but instead implies superstition, idolatry and polytheism, as well as the making of violent sacrifices and later on hostility towards the Christian religion. ${ }^{156}$ From the fourth century onwards, pagani ("pagans") (which has no precedent in Greek) began to replace gentes, probably because of the polysemy of gentes and because the pejorative meaning of gentes was seen as not strong enough. ${ }^{157}$ In the language of the councils, gentiles ${ }^{158}$ took the place of gentes. ${ }^{159}$ In the Latin Old Testament (in the Vetus Latina), gentes was initially only used for the non-Jews (while at the same time its general meaning "races," "tribes," "nations" persisted). ${ }^{160}$ It was when Christians began to dissociate themselves further from both the faithless non-Jews and the Jews that they first perceived pagans and Jews as a single entity. However, when Christianity was made the 'state' religion, the term gentes became not only further opposed to the Christians but also opposed to the Jews and Israel. ${ }^{161}$

What I try to do below is to examine the occurrences and determine the exact meanings of imperium and gentes in the contexts of first Alcuin's epistle and then his poem on York. ${ }^{162}$ I explore the ways in which imperium and gentes are employed by Augustine, particularly in his De civitate Dei, and analyse the correlation between Alcuin's and Augustine's uses of the two political terms. At the same time, it is demonstrated how the terms subicere, subdere, iugum and regna terrarum are assembled around the terms gentes and imperium in several of Alcuin's texts and that the sender, in so doing, imitates the political discourse Augustine shaped in the De civitate Dei (when evaluating God's arrangement of worldly power in time and space), in order to make his own judgment about Carolingian rule. Eventually, I recapitulate the significance of the manner in which Alcuin avails himself of imperium and gentes.

The contents of Alcuin's Epist. 178 sent to Charlemagne in preparation for the imperial coronation are, firstly, that the king's successes and triumphs should assist God in subduing the heathen gentes ("races") everywhere and put them under the yoke of Christian belief. Furthermore, according to God's plan, Charlemagne's 
extraordinary power should facilitate the conquering and Christianisation of many realms of the earth. For God's grace presents Charlemagne once more with the two exceptional gifts of imperium ("supreme power") and spiritalis sapientiae latitudo ("the breadth of spiritual wisdom"). ${ }^{163}$ The gifts of "supreme power" and "the breadth of spiritual wisdom," with which God's grace favoured the king, stand out as being of crucial importance in this epistle, and Alcuin describes this bestowal as extraordinary. ${ }^{164}$ Obviously, imperium refers to a power to which not every ruler is readily entitled. Eventually, Alcuin's conclusion that a ruler so richly endowed by God should spare his converted people and defend the 'churches' of Christ builds a bridge to the Roman empire and to the De civitate Dei; after quoting a hexameter from Virgil's Aeneid, Alcuin comments that it was originally meant to address the emperors of the Roman empire. More importantly, he explicitly states that the very same line is also discussed and cited with praise in Augustine's De civitate Dei. ${ }^{165}$ By referring to this passage, in which Augustine discusses the sovereignty, function and supreme qualities of the Roman power as an eschatologically relevant empire and cites Virgil to support his argument, and by making the same appeal to the Carolingian king as Virgil made to the Roman emperors, Alcuin places Charlemagne and his realm on an equal footing with that of the Romans and its emperors. However, at the time the letter was written, Charlemagne was a Christian ruler who had not yet received the title of imperator. Examining Alcuin's use of imperium within its context has helped to perceive the equation made between Charlemagne and the imperatores Romani regni in this epistle, and to discern the fact that Alcuin portrays the Carolingian ruler as superior to the imperatores Romani regni by indicating to Charlemagne as king that he is exceptional because he has already achieved the status of an emperor before having obtained the imperial title.

Turning to the term gentes, we find that it occurs only once, in the opening of the epistle. ${ }^{166}$ The lines in which gentes appears speak about God and his plan to use Charlemagne's strength as a tool for conquering hostile tribes and converting them to Christianity for their own well-being. They can be translated as follows:

We have received the writings about your prosperity and our comfort with great love and worthy good will, which praise very much the clemency of the almighty God, who arranged that you and your loyal people be strong with prosperous accomplishments and who placed the enemies of His own name below the feet of your power.

Indeed, God should do this, and should add this, so that He may subject the hostile races from all directions with the triumph of your terror; and that He may subject the fiercest minds by the sweetest yoke of His love to the Christian faith, so that only God and our Lord Jesus Christ be held true, worshipped, and loved.

Your most illustrious power and most sacred will should be involved in this extensive striving, so that Christ's name should be made famous and his divine power become known to many realms of the earth through the triumphs of your strength $[\ldots] .{ }^{167}$ 
It seems that the word gentes here refers to groups of people that are enemies from outside but inferior to Charlemagne's power. Moreover, these peoples are characterised as non-Christians who are on the verge of being imbued with Christian principles; as I argue further down, Alcuin's use of the term gentes, in the sense of non-believers and lower-ranking tribes, owes a great deal to Augustine.

Two passages from Alcuin's Vita Willibrordi archiepiscopi Traiectensis show the terms imperium and gentes as two polar ideas, whereby imperium intimates the Carolingians' supremacy over gentes. ${ }^{168}$ The first passage, which relates to the takeover of Charles Martel from his father Pippin of Herstal, reads thus:

Moreover, it occurred that Pippin, Duke of the Franks, died and his son Charles obtained his father's realm.

He added many races to the rule of the Franks, among them he also added Frisia with the glory of triumph to the fatherly power, after having overpowered Radbod. ${ }^{169}$

The second passage celebrating the descent and accomplishments of Charlemagne is worded as follows:

He [Willibrord] then baptised Pippin, the son of the strongest Duke of the Franks Charles, the father of this most noble Charles, who presently governs the empire of the Franks most gloriously with the greatest triumphs and every dignity. $[\ldots]$

For the entire people knows by what triumphs the most noble victor is celebrated, or how far he stretched the boundaries of our empire, or how devotedly he propagated the Christian religion in his realm, or what he effected for the defence of the holy 'church' of God among the races from without. ${ }^{170}$

Another set of expressions that appears in Epist. 178 together with gentes and reinforces its meaning of hostile, subordinate tribes to be converted, involves iugum, subicere, subdere and regna terrarum. The sentence concerning the gentes also includes the noun iugum ("yoke") once, and the verb subicere ("to subject") twice, where Alcuin says: God "[...] may subject the hostile races from all directions $[\ldots]$ " and "[...] may subject the fiercest minds by the sweetest yoke of His love [...]." In the preceding sentence, these gentes are already referred to as ungodly, hostile groups of people who are defeated by Charlemagne; Alcuin chooses subdere in the phrase "God [...] who placed the enemies of his own name below the feet of your power." Alcuin's double use of subicere in the opening section of the text is a prelude to Virgil's hexameter cited by Augustine (parcere subiectis et debellare superbos), which follows as a quotation further down in the epistle.

In Epist. 257, ${ }^{171}$ the letter addressed to Charlemagne after his imperial coronation, in which Alcuin makes known his opinion about Charlemagne as an exceptional Christian emperor, various forms of the verb "to subject" (subicere) also constitute a theme throughout the text, in order to strengthen the allusion to 
Virgil's hexameter contained in the De civitate Dei. ${ }^{172}$ Likewise, the verb subdere ("to subdue") features in this correspondence - right next to gentes and subiectio, when Alcuin comments: "divine grace [...] inflicts the terror of your [Charlemagne's] power upon all the races from all parts, in order that those come to you by voluntary subjection, whom the labour of war could not subdue at earlier times." $" 173$

In Epist. 110 we meet the same constellation of words. ${ }^{174}$ It is the letter to the king on the process of conversion. The Frankish people are presented as being elected by God to form the perfect Christian 'state' on earth. By God's own favour, their ruler is said to have been divinely ordained to execute God's plan to increase the number of predestined members of the civitas Dei by military expansion and Christianisation. Alcuin calls Charlemagne the "lover of truth and of the salvation of many" (veritatis et salutis multorum amator). ${ }^{175}$ Hence, Charlemagne will be particularly rewarded on Judgment Day when leading this vast nation to salvation. The words gentes and iugum can be found several times in the text. The lines in which Alcuin uses gentes, iugum and subdere together parade Charlemagne as the glorious executor of God's will and give an account of his success in taming and Christianising the savage Avars. Alcuin's words are:

The races and peoples of the Avars, terrible by their old wildness and strength, He [God] placed to His own honour under your military authority: and foreseeing grace He conquered the necks that have been most arrogant long enough by the yoke of holy faith, and He poured the light of truth into the minds that had been blind since ancient time. ${ }^{176}$

In Epist. 41, where the pseudonym David is first established, the noun gentes occurs twice and the verb subicere once. ${ }^{177}$ In the crucial sentence introducing King David as Charlemagne's analogue, both expressions appear together when Alcuin relates: "In such a way also David, once king of a preceding people, was elected by God and loved by God and, as an excellent psalmist of Israel subjecting by his victorious sword races from all directions, emerged among the people as a chosen preacher of the law of God." 178

The same cluster of words features in Epist. 119, a letter to Charlemagne's son, Pippin of Italy. ${ }^{179}$ At the beginning of the correspondence, Alcuin alerts Pippin to the enormous moral obligation he has as a successor of such a noble lineage and Christian king (Charlemagne). He reminds Pippin that God will only favour his rule to the same level if he fulfils this obligation. Here again Alcuin avails himself of the terms gentes and subicere. He exhorts Pippin:

And you, most excellent youth, should be eager to embellish the excellence of your birth by excellence of conduct; and seek zealously to satisfy the will and the honour of the omnipotent God through every virtue; to the extent that his unutterable piety exalts the throne of your realm and extends its borders, and subjects the races to your power. ${ }^{180}$ 
The phrase regna terrarum in Epist. 178 emerges in the sentence after the one containing gentes, iugum and subicere. It here refers to any worldly 'state'. Alcuin uses the phrase regna terrarum when expressing his hope that, through Charlemagne's power and will, the Christian religion will be spread across many realms. Alcuin notes: “[...] Christ's name should be made famous and his divine power become known to many realms of the earth [...]." ${ }^{181}$ A more complex phrase containing regna terrarum can be located in Epist. 202. ${ }^{182}$ At the end of this letter, Alcuin again expresses the wish that through Charlemagne's will and power the Christian faith may be defended, taught and propagated and the imperium Christianum ("Christian empire") expanded. To this, he adds: "[...] with Him assisting, in whose power are all realms of the earth [...]" (ipso auxiliante, in cuius potestate sunt omnia regna terrarum). ${ }^{183}$ The word combination regna terrarum here, in the vicinity of imperium Christianum designating Charlemagne's empire, expresses its implied meaning of "all earthly realms."

In Alcuin's poem on York, ${ }^{184}$ we come across instances of both imperium and gentes. Probably the most common meaning of imperium in the poem is "empire," "world power" or simply "realm having power over others." In one case, imperium stands for the Roman "empire" or "world power"; it says that York had first been built by the Romans and that Britannia, then fertile, supported their venture rightfully, "[...] in order that it be a public trading centre of land and sea, /and become to military commanders a fearless force of the realm, /and a glory of the empire and a terror to hostile arms [...]." ${ }^{185}$ In another case, imperium refers to a "realm having power over others," when the successful King Edwin expands his realm. The poem says: "[...] in assiduous triumphs defeating the hostile military camps, /he added to his realm all the races, /[...]. /And already the people of the Saxons, the Pict and the Scot, the Briton /went with a curbed neck under the yoke of the leader $[\ldots] .{ }^{" 186}$

As in the letters discussed above, the plural gentes in Alcuin's poem has (mostly) the meaning of "subordinate races/tribes/nations." When the foundation of York is described, Alcuin writes: "This one [the city of York], high with walls and towers, /the Roman hand founded first, drawing on the native British races / only as partners and sharers of labours [...]." ${ }^{187}$ In the second example of imperium above, gentes is used to denote nations inferior to Edwin's realm, which are conquered by him. ${ }^{188}$ In the very same quote, one can also spot the noun iugum in the sentence immediately following the one comprising imperium and gentes.

An investigation of Augustine's use of imperium in the De civitate Dei shows that imperium primarily occurs in the books ${ }^{189}$ dealing with politics and the characteristics of Roman power. Only rarely is imperium found as a spiritual/religious concept. ${ }^{190}$ In many instances, imperium is used in the sense of "empire" or "world power" and often refers to the Roman empire ${ }^{191}$ (imperium Romanum) and occasionally to other supreme 'states'192 (i.e. 'states' dominant over others in power and influence). In one case (Chapter 7 of Book XIX ${ }^{193}$ ), imperium $^{194}$ or imperiosa civitas $^{195}$ simply represents a sample model of a superior 'state', which, in order to be able to communicate with its neighbours, first conquers them and then together with the peace treaty imposes its language on the freshly subdued 
"races" (gentes). However, Augustine draws attention to the fact that even when this state is reached, peace is not once and for all secured, because enemies from the outside must be warded off continually, and the imperium strives for constant expansion. The result is a never-ending cycle of war. This example shows that in the De civitate Dei, imperium clearly has unhappy connotations of war and repression. Apart from this, imperium in Augustine's work frequently implies "supreme power (of Roman emperors)"196 and "command."197 What is notable about the forms in which imperium emerges in the De civitate Dei is that they generally carry connotations that refer to the military. It is therefore not surprising that in the De civitate Dei, imperium hardly has a spiritual or religious meaning. It also suggests that Augustine's spiritual community, the civitas Dei, is incompatible with any form of military power. In the De civitate Dei, the word imperium is, for instance, also found in the verses Augustine quotes from Virgil, where it says the Roman should govern the peoples with imperium ("supreme power"). ${ }^{198}$ Overall, it can be said that although Augustine does recognise some positive contexts for the use of force (e.g. against pagans, non-believers and schismatics), these are mainly worldly and therefore have no place in the city of God.

Bullough has explored the political term imperium. ${ }^{199}$ He broadly translates imperium as "lawful authority/rule." 200 Alongside this more general translation, Bullough refers to a specific meaning of imperium - "authority exercised over other gentes and their rulers"201 - which he attributes particularly to early medieval England and Alcuin. Yet the examples from the De civitate Dei given above (not least the multiple occasions in which imperium stands for the dominant Roman power) explicitly manifest that imperium in this particular sense was already frequently used by Augustine (and Virgil). McKitterick and J. L. Nelson agree that Alcuin (and Bede) used imperium in order to denote "power over many subject peoples." ${ }^{202}$ It turns out that to both Alcuin and Augustine, imperium as a term for a 'state' is reserved for a power that has supremacy over other 'states' or, in Augustine's terms, for 'states' that are eschatologically relevant. In an article entitled "The Imperial Coronation of Charlemagne," 203 Ganshof evaluates the significance of Alcuin's political thought in the lead-up to the imperial coronation and treats the meaning of Alcuin's notion of imperium in depth. While Ganshof broadly holds that Alcuin's impact on Charlemagne's elevation is undeniable, ${ }^{204}$ he sets out in detail the crucial argument put forward by A. Kleinclausz, L Halphen, ${ }^{205}$ U. Pfeil, E. Caspar ${ }^{206}$ and particularly H. Löwe and E. E. Stengel ${ }^{207}$ that Alcuin made his notion of the imperium Christianum, which started to appear in Alcuin's correspondence around 798 and was often used by him up to $801 / 802,{ }^{208}$ familiar to Charlemagne in order to acquaint him with the idea of emperorship. ${ }^{209}$ In a similar way, according to Ganshof and the scholars he cited, this term gradually conquered the minds of other Frankish clerics of the royal circle, such as Alcuin's confidential agents, whom he had sent to Rome in 800: Witto (Candidus), Fridugisus (Nathanael) and other monks of Saint-Martin. ${ }^{210}$ The expression imperium Christianum especially features in Alcuin's epistles to Arn of Salzburg, and Ganshof reasons that another of Alcuin's correspondents, Angilbert of SaintRiquier, shared Alcuin's thoughts on empire. ${ }^{211}$ Alcuin's imperium Christianum, 
according to Ganshof, corresponds to the whole of the territories submitted to Charlemagne's authority and inhabited by the populus Christianus, which is the community of Christians spiritually dependent on Rome. ${ }^{212}$ Charlemagne's duty is to govern, defend and enlarge it, and linked with these obligations is his task to protect faith and 'church'. ${ }^{213}$ Ganshof specifically contends that the term imperium Christianum has a 'geographical' meaning since Alcuin mentions its frontiers and alludes to a territory in some of his epistles. ${ }^{214}$ Ganshof here argues along the lines of Caspar and Pfeil and dismisses above all the views of Löwe, who rejected any meaning of imperium Christianum apart from a purely religious one. ${ }^{215}$ In the light of the evidence provided above, that Alcuin most likely drew from Augustine the notion of imperium as a power with supremacy over other 'states', ${ }^{216}$ the following theory promoted by Löwe and Stengel, and debated by Ganshof, is noteworthy with regard to Charlemagne's acquaintance with the concept of emperorship; one important constituent of Charlemagne's idea of imperial dignity is, according to Löwe and Stengel, a notion of authority, conceived as a superior royal power i.e. a power of supremacy - which was already familiar to the Franks. ${ }^{217}$ These scholars reason that since the notion of imperium would have been known to the Anglo-Saxons in the sense of a power of supremacy (in this regard they anticipated Bullough's conclusion), imperium would have contributed to the creation of the notion of empire as understood by Charlemagne. ${ }^{218}$ In other words, Löwe and Stengel suggest that Alcuin was particularly successful in making Charlemagne familiar with his understanding of imperium because a similar notion of authority already existed among the Franks. While this theory may or may not be accurate, it is certainly an indicator of the wide acceptance of the idea that Alcuin was the one who drew Charlemagne's attention to the notion of imperium in the sense of a power having supremacy over other 'states'. ${ }^{219}$ Alcuin then additionally conferred a spiritual Christian meaning on this idea of imperium as a notion of supremacy.

The definition of gentes relevant to Augustine seems to be "less influential groups of people." ${ }^{220}$ For example, again in Chapter 12 of Book V of the De civitate Dei, Augustine writes when quoting Virgil:

Hence, there is also that [extract] from the same poet [Virgil], which, since he [Virgil] prefers these very distinctive skills of the Romans - to reign over and also to rule over and to subjugate and furthermore to vanquish peoples - to the skills of other groups of people, says: some will forge the blazing metals more smoothly,

indeed I admit that they will derive living faces from marble,

that they will plead their causes more convincingly, that they will both describe the movements of the sky with a pointed rod and tell the risings of the stars: you Roman, remember to govern the peoples with supreme power

(these skills will belong to you) and to establish morals for peace, to spare the subject peoples and to vanquish the proud. ${ }^{221}$

Here it becomes apparent that the Romans, due to their special achievements, are thought to rank above the other races, whose achievements are considered 
second-rate. The term iugum ("yoke") in Alcuin's texts, in sentences expressing authoritative leadership, is reminiscent of the recurring verb subiugare ("subjugate") in the extract above (Chapter 12 of Book V ${ }^{222}$ ) and in Chapter 2 of Book XVIII of the De civitate Dei, where Augustine contends:

For in almost all races in some measure the well-known voice of nature resounded that they would rather choose to be subjugated by their conquerors, to whom it occurred that they were conquered, than to be destroyed by any kind of military ravaging.

From this cause it was arranged, not without the providence of God, in whose power it is that every one is either subjugated or subjugates in war, that some are endowed with realms, others are subdued to those with royal power.

But among most of the realms of the earth, into which society is divided for its earthly welfare or rather cupidity (which we call by the universal name of worldly 'state'), we discern that two realms have come forth as by far the more prosperous compared to the others; first that of the Assyrians, then that of the Romans, ordered and separated in time and space between themselves.

For in the manner in which the former was before, this one was later in order: in this manner the former rose in the East, this one in the West; in short, in the final stages of the former was immediately the beginning of this one.

The other realms and the other leaders I would like to designate as some sort of appendages to these well-known ones. ${ }^{223}$

In the quotations of Alcuin as well as in both excerpts from the De civitate Dei (Chapter 12 of Book V and Chapter 2 of Book XVIII), subiugare and iugum appear in close proximity to the word gentes. The term subicere is likewise part of the hexameter Augustine quotes from Virgil in Chapter 12 of Book V. Even the verb subdere has a prominent position in Chapter 2 of Book XVIII, emerging in the context of gentes, subiugare and regna terrarum. The sense Augustine gives to regna terrarum here matches the one Alcuin is acquainted with: "any earthly realms."

One of the routes by which ancient political concepts such as regna terrarum found their way into early medieval texts runs via the historiographer and Bishop Isidore of Seville, whose reflections are to a large extent based on Augustine's thinking. ${ }^{224}$ This link is clear in the following passage from the Etymologiarum sive Originum libri $X X$ where Isidore's use of regna terrarum is documented. ${ }^{225} \mathrm{In}$ addition, the text illustrates how Cicero's etymological claim - regnum is derived from rex -, which is also adopted by Augustine in the De civitate Dei, ${ }^{226}$ was passed on:

\section{About the Realms and the Terms of Military Service}

Regnum is derived from reges.

For just as rulers are named from ruling, so is realm from rulers.

All nations without exception had a realm at their particular times, like the Assyrians, Medians, Persians, Egyptians, Greeks, whose succession the 
fate of times turned over in a manner that the former $[P \mathcal{E} \alpha \lambda \mu]$ as terminated by the latter.

But among all the realms of the earth two realms are related to be famous compared to the others: First that of the Assyrians, then that of the Romans, both in time and space in good order and distinct within themselves.

For in the same way as the former was before and this one was later in order, so the former arose in the East, this one in the West: in short, in the final stages of the former was immediately the beginning of this one.

The other realms and the other leaders are regarded as some sort of appendages to these well-known ones. ${ }^{227}$

In Alcuin's sources, the more complex word combination in cuius potestate sunt omnia regna terrarum, ${ }^{228}$ found in Epist. 202, ${ }^{229}$ has moreover been highlighted. The exact same formulation does not exist in Augustine's De civitate Dei. However, three instances where Augustine uses almost the same wording occur within the first five books of the text. The phrases are: "[...] in whose power are all realms [...]" (in cuius potestate sunt regna omnia) $)^{230}$ and "[...] in whose power are also the earthly realms" (in cuius potestate sunt etiam regna terrena). ${ }^{231}$

At this point, it is worth looking at the surviving Carolingian copies and corrections of copies of Augustine's De civitate Dei, ${ }^{232}$ which are the following:

$L^{2}$ Codex Lugdunensis 607 (Lyon), saec. VI (lib. I-V), correcturae, saec. IX I Codex Lugdunensis 606 (Lyon), saec. IX (lib. I [in.]; VI-XIV)

$\Lambda$ Codex Lugdunensis 606 (Lyon), saec. IX (lib. I-V)

F Codex Monacensis (München) Lat. 6267 (Frising.), saec. IX (lib. I-XVIII)

K Codex Coloniensis 75 (Köln) (Darmstadt. 2077), saec. VIII (lib. I-X)

G Codex Sangallensis 178 (St.Gallen), saec. IX (lib. XI-XXII)

These indicate that by the end of the ninth century all books of the De civitate $D e i$ were known. It further appears that in the eighth century the knowledge of the De civitate Dei may have been limited to the first ten books and the first five must have been best known. The oldest manuscript of the De civitate Dei that has been preserved, the Codex Lugdunensis 607, from the sixth century, also only comprises the first five books. The ninth-century Carolingian manuscripts again show that there seems to have been a certain interest in copying particularly the first books (up to Book XIV). Maybe Carolingian scribes generally endeavoured to copy Augustine's work from the beginning, but then gave up part of the way through. However, by considering the development of the author's argument in the De civitate Dei, some interesting observations can be made; in the first five books of the De civitate Dei, Augustine primarily responds to the gradual disintegration of the Roman empire and embeds this event into salvation history. He assesses the heathen and Christian Roman 'states' and expresses particular approval of the Christian emperors Constantine I and Theodosius I. Augustine also rates and compares several influential temporal 'states' in the first ten books and reflects on the value of secular power at large and the role of free will and 
divine providence in the transmission of power. In Books X to XVIII, the two communities civitas Dei and civitas terrena are then properly introduced; their origin is explained, and they are characterised and juxtaposed. In the remaining books, Augustine transcends the present status quo and links earthly happenings with salvation history. Thus, it is confirmed that the discussion of the value of secular power and the concrete evaluation of specific temporal 'states' according to certain criteria in the first ten books were deemed to be the most critical contents of the work by Carolingian readers. They certainly attracted attention. Alcuin must have known them to the extent that he internalised Augustine's language and reused phrases such as in cuius potestate sunt omnia regna terrarum, which keep occurring in the first five books of the De civitate Dei.

It has become evident that Augustine uses gentes often in the sense of less influential groups of people. Bullough, too, makes reference to the word gentes in connection with Alcuin, and the definition suggested by him corresponds exactly to that which is relevant to Augustine: less influential groups of people. ${ }^{233}$ What is more, in the Augustinus-Lexikon it is noted that, according to Augustine, gentes in a pejorative sense usually means "non-believers." ${ }^{234}$ And here the AugustinusLexikon (s.v. gentes) refers to a particular differentiation Augustine makes between the Jews and the gentes as "non-believers," as, in the course of the fourth century, gentes became opposed to the Jews and Israel. ${ }^{235}$ Augustine takes this opposition further. He devalues the Jews in relation to the gentes (arguing that they are far more to blame for Christ's death), seeing the Jews as arrogant, the gentes however as somewhat humble, since they will at least eventually open up to the Gospel. ${ }^{236}$ Now, if we return to Alcuin and to the single instance of gentes in his epistle 237 ("Hoc enim faciat Deus [...]"), we discover that gentes in this context suits Augustine's notion of gentes who are to open up to conversion.

If we re-evaluate the appearance of the notions of imperium and gentes in the vicinity of the terms subicere, subdere, iugum and regna terrarum in Epist. 178 to Charlemagne, in the poem on York and in other sources, we find that, in alignment with Augustine's understanding, imperium for Alcuin must have meant "ruling over gentes" (in the sense of inferior groups of people who will eventually open up to conversion). Having observed Augustine's multiple use of imperium with reference to the superior Roman empire in the De civitate Dei, it appears valid to say that Alcuin, by quoting from the passage in which Augustine discusses the sovereignty, function and supreme qualities of the Roman power as an eschatologically relevant empire, seeks both to link Charlemagne's rule with the Roman empire and confer eschatological significance to Charlemagne. To Alcuin and Augustine, the title of imperator therefore seems to be reserved solely for rulers who have the supremacy over other rulers in power or, in Augustine's terms, for eschatologically relevant rulers. It is in view of this that Alcuin's equation of King Charlemagne with the imperatores Romani regni in Epist. 178 takes on its true meaning.

In one regard, however, Alcuin's understanding of imperium and imperator differs from that of Augustine. As shown above, to Alcuin these notions do not simply refer to eschatologically relevant empires and rulers in the sense of 
the Assyrians, whom Augustine deems relevant to the Old Testament (birth of Abraham $^{238}$ ), and the Romans, whom he considers relevant to the New Testament (birth of $\mathrm{Christ}^{239}$ ), but to an actual people of God on earth. This difference is manifested in the single distinction in meaning of the word imperium in Augustine and Alcuin's texts; it has been pointed out that imperium in the Classical Roman Period commonly carried a connotation that refers to the military. Similarly, the forms in which imperium can be found in the De civitate Dei also almost exclusively carry that connotation. There, imperium hardly has a spiritual or religious meaning, which proposes that Augustine's spiritual community, the civitas Dei, is in principle at odds with any secular political power. This corresponds to Garrison's claim that Augustine interpreted the Psalms beata gens and beatus populus always in a purely spiritual way, i.e. as referring to the heavenly kingdom. ${ }^{240}$

The military usage of the word imperium as observable in the De civitate $D e i^{241}$ is, for instance, still prevalent in Isidore's Etymologiarum sive Originum libri $X X$. In one instance, Isidore examines the different titles of Roman rulership and reasons:

The name of the Caesars began with Julius, who, after a civil war had been provoked, was the first of the Romans to obtain single supremacy.

However, he was named Caesar either because he was carried and drawn out of his dead mother's womb after it had been cut open, or because he was born with long hair.

Henceforth also the succeeding emperors were named Caesars, for the reason that they were long-haired.

Indeed those, who were taken out of the cut womb, were called Caesones and Caesars.

But Julius he was named, because he derived his origin from Julus, the son of Aeneas, as Vergil confirms: Julius, the name deduced from the great Julus.

However, the name emperors existed among the Romans much earlier, among whom it was founded on the highly important military institution, and from there emperors were named from the commanding of the army; yet, while for a long time the generals had served under the title of emperors, the senate decreed that this name should belong to the Caesar Augustus alone, and by that $[v \alpha \mu \varepsilon]$ he should distinguish himself from the other leaders over races; that $[v \alpha \mu \varepsilon]$ rom then onward also the succeeding Caesars used.

For it is common practice to happen that the name of the first leader also the future ones possess, just as among the Albanians from the name Silvius all the leaders of the Albanians are called Silvii; in the same way as among the Persians they are called Arsacids; among the Egyptians Ptolemies; among the Athenians Cecropids.

Accordingly, Augustus is among the Romans the name of the empire, from there that they once had augmented the republic by enlargement.

In the beginning the senate bequeathed this name to Caesar Octavian, in order that he may be deified under this very name and title, for the reason that he had expanded the territories. 
But at the time when the very Octavian was already called Caesar and emperor, or Augustus, indeed later on, when he was watching the games, and it was proclaimed to him by the people that he should also be called "Master", he repressed the inglorious flatteries instantly with a hostile hand and facial expression and refused the name "Master" like a human being, and on the following day he even rebuked the entire people in a very grave proclamation, and he thereupon would not even permit his freedmen to call him "Master" any more.

However, he was the son of Actia, who was the offspring of the sister of Julius Caesar. ${ }^{242}$

This treatise on the origin of the titles of Roman rulership draws attention to the widespread custom among nations of naming an entire dynasty after the first ruler in line. The title of imperator ("emperor") is expounded by Isidore in particular detail; after explaining its emergence in the Roman army, he hints at a Senate decision which prescribed that henceforth Caesar Augustus (Gaius Octavius) alone should be titled imperator, in order that he could distinguish himself from the other reges ("leaders") over gentes ("races"). According to the old custom, Isidore states, the title of imperator was then transferred to the subsequent Caesars. Bullough's argument suggests that the Senate's idea of the exclusiveness of the title of imperator is shared by Isidore. ${ }^{243}$ It is obvious that Isidore's terminology is strongly influenced by Augustine. However, Alcuin's understanding of imperium stands in contrast to the political term imperium in classical Roman texts, in Augustine's writing and in Isidore's; Alcuin's notion of imperium, which gains prominence in the correspondence leading up to Charlemagne's imperial coronation, refers to a secular military power at the same time as having a strong spiritual connotation.

This second part has attempted to trace various forms of reference to Augustine in Alcuin's writing. What has been observed is the consistent way in which Alcuin draws on Augustine through both direct quotation and through a more indirect, but nevertheless pervasive borrowing of concepts. In the first chapter of Part II, concerned with Alcuin's explicit use of Augustine, several epistles showed that, in the more instructional parts of the content, Augustine is presented as the most distinguished authority and as a binding guideline in questions relating to Christian doctrine. In the second chapter of Part II, Alcuin's texts were examined for implicit reference to Augustine in content and language. This kind of indirect reference is confirmed by the fact that nearly all the letters mentioned in the first part on direct reference emerge also in the second part on indirect reference (Epist. 307, Epist. 136, Epist. 178, Epist. 257, Epist. 249, Epist. 110, Epist. 177, Epist. 202). This shows that, in one and the same piece of writing, explicit reference tended to be used in statements that served to instruct in the domain of Christian faith, while implicit reference, below the surface, forms part of an underlying political discourse that begins to permeate Alcuin's texts from 794 onward (after Charlemagne's move to Aachen), when the pseudonym David came into use. 
Alcuin manifestly reinvented Augustine to suit his own project. He availed himself of the ideas of iustitia ("justice") and pax ("peace") in his correspondence with Charlemagne, and in Epist. 41 and Epist. 229 alluded to Psalms 32 and 143 (including the verses Beata gens cuius est Dominus Deus eius and beatus populus cuius Dominus Deus eius), fulfilment of which Augustine had made the precondition for a civitas Dei. Thus, it is clear that Alcuin was well acquainted with the harsh and seemingly unachievable criteria Augustine had set for a 'state' to gain the status of a civitas Dei. Alcuin assessed the Carolingian 'state' according to these strict criteria, established by the Church Father with the most negative stand on worldly rule, to give a positive evaluation of Charlemagne and his people. His argument is that, while even Old Testament Jerusalem and the reign of its kings had been doomed to failure and the Christian Roman emperors likewise had not succeeded in meeting Augustine's challenge, Charlemagne is the first ruler capable of doing so by leading a people perfectly under the command of the Christian God. Moreover, by using Augustinian political thought in order to make a positive statement about Carolingian rule, Alcuin resolves the tension in Augustine's argument in the De civitate Dei, i.e. the author's dilemma between approval of the supreme worldly power of Christian rulers and harsh criticism towards any form of worldly social organisation, government and power.

In several instances, Alcuin portrayed Charlemagne as superior to any other authority by stating that he had gained and deserved imperium ("supreme power")/potestas/potentia ("power") and sapientia ("wisdom"), which reflected the ruler's political and religious responsibilities of defending and enlarging his realm and defending and spreading the Catholic Christian faith, to a higher degree than any past or present political figure (Epist. 246, Epist. 178, Epist. 257, Epist. 174). This places Charlemagne's 'state' above the 'states' of the Assyrians and Romans, which Augustine presents as eschatologically relevant in the De civitate Dei. Throughout his correspondence after 794, Alcuin applied the names of the two Biblical kings David and Solomon to Charlemagne and/or one of his sons (Epist. 246, Epist. 41, Epist. 217, Epist. 177, Epist. 174, Epist. 198, Epist. 139, Epist. 229, Epist. 148). Thereby, he portrayed both Charlemagne and Christ as related to King David and linked the Carolingians directly with Christ by using the formula populus Christianus ("Christian people") for Charlemagne and his son's people as well as for Christ's people of God (Epist. 41, Epist. 217, Epist. 177). What is more, in Epist. 198 Alcuin presented Charlemagne's civitas as superior to Jerusalem and the reign of the Old Testament kings, which were doomed to destruction. Also in Epist. 110, written to Charlemagne (and "the preachers of the words of the holy God") and dealing with the complexities of subjugation and Christianisation, it becomes evident that Alcuin saw the Carolingian 'state' as a godly realm. The writing suggests that - as opposed to Augustinian thought eternal life was perceived as guaranteed to all of Charlemagne's faithful subject peoples through their perfected Christian faith.

Yet Alcuin did not stop there; he literally termed Charlemagne's 'state' perpetuae pacis civitas ("city of eternal peace") and civitas Dei ("city of God") (Epist. 198, Epist. 139, Epist. 76, Epist. 89) and thereby proposed that the conditions 


\section{Alcuin of York}

of iustitia and pax in the Carolingian realm were not the worldly, but in fact the divine, forms of these concepts. What is noteworthy about the contexts in which these expressions are used is that Alcuin, with this statement, was not merely trying to reach out to Charlemagne himself. In Epist. 139, Alcuin conveyed his admiration and respect for Paulinus II of Aquileia's involvement against heresy and offered him encouragement and support. He is represented as the primary defender of the Catholic 'church', on whose victory the entire Christian community (including its leader Charlemagne) relies. Paulinus appears as the guard of the doors of the civitas Dei as well as the holder of the clavis Daviticae potentiae ("key of David's power"). Charlemagne's 'state' is pictured as the perfect Christian community on earth, which is defended from ungodly attackers from the outside by Paulinus. According to Alcuin, Paulinus was the man who knew best the doctrine of Catholic faith and was therefore the legitimate protector of the power of the ruler of the civitas Dei, Charlemagne (in the person of King David). In Epist. 198, right after addressing Charlemagne as King David, Alcuin contrasted the Carolingian 'state' with Old Testament Jerusalem (referred to as condemned to certain destruction) by naming it perpetuae pacis civitas ("city of eternal peace"). Alcuin clearly considered himself to be a member of Charlemagne's civitas when he called himself: "[...] I, some insignificant part of this city [...]" (ego, minima quaedam huius civitatis portio). In Epist. 76 to Bishop Remedius and in Epist. 89 to a bishop in England, Alcuin's primary concern was to give support, confidence and hope. In Epist. 89, Alcuin cordially brought a bishop's main commitment - to preach the word of God with conviction and assertiveness - to the addressee's attention. Epist. 76 stresses the importance of loyalty and friendship between distant associates. The hope of a promise of eternal happiness among the members of the civitas Dei is expressed at the end of each correspondence. These contexts reveal that Alcuin indeed tried to win his acquaintances over to the political discourse he had established among Charlemagne's inner circle. Alcuin's programme was undeniably to include - even actively to involve - his peers. He made the civitas Dei a joint project.

\section{Notes}

1 Rep. I 39, p. 28.

2 Epist. 246, pp. 393-399.

3 Meens 2007, p. 277. An overview of Charlemagne's legal efforts and settlement of disputes is provided in Davis 2011, pp. 149-173.

4 Ibid., pp. 277-300.

5 Ibid., pp. 282-283.

6 Ibid., p. 283.

7 Ibid., p. 284.

8 Ibid., p. 285.

9 The Christian form of sanctuary dates back to the middle of the fourth century and is a continuation of Greek and Roman practices related to the imperial cult of granting sanctuary in sacred places. During the late fourth and early fifth centuries (at the time of Augustine's episcopate), imperial expenditures and corruption resulted in a growing tax burden and in an increasing number of delinquent 
taxpayers who sought sanctuary in 'churches'. A constitution dated 18 October 392 recognised the custom of sanctuary in 'churches' but excluded from its protection certain types of offenders (among them delinquent taxpayers). The bishops assembled at the Council of Carthage (399) appealed to Emperor Honorius to allow sanctuary in 'churches' to anyone. On 21 November 419, the emperors Honorius and Theodosius II eventually issued an edict recognising an inviolable right of sanctuary that extended to within fifty feet of the doors of Christian 'churches'. Dodaro 1999, pp. 178-179.

10 Another epistle from Alcuin to the emperor sent around 800/802, Epist. 249, draws parallels between Charlemagne and the Roman emperors when reminding the ruler of the value of the virtue of clementia ("clemency"). Here Alcuin asserts: "... clemency to his subject peoples was always a special virtue, excellence and praise of the emperors, in so much as the most noble Emperor Titus says that not a single one should depart in sadness from the emperor." (“... specialis virtus bonitas atque laus imperatorum semper fuit clementia in subiectos suos, in tantum ut Titus nobilissimus imperator ait neminem ab imperatore tristem debere recedere.”) Epist. 249, p. 403, lin. 43.

11 Epist. 178, pp. 294-296.

12 Ganshof 1949, p. 15. See also the discussions in Wallace-Hadrill 1971, pp. 102-103; Wallace-Hadrill 1975, pp. 188-190.

13 Epist. 257, pp. 414-416.

14 The manual De fide sanctae et individuae Trinitatis, completed at Saint-Martin around 802, is Alcuin's most influential work. See Cavadini 1991, pp. 124-125.

15 Epist. 257, p. 414, lin. 20.

16 Epist. 178, pp. 294-296.

17 Aen. 6.853. A discussion of the reception of Virgil in Alcuin's work can be found in Holtz 1997, pp. 67-80.

18 Civ. V 12, p. 213, 1. 30.

19 His duobus, sancte imperator, muneribus divina vestram inconparabiliter sublimitatem, eiusdem nominis et numinis antecessoribus gratia superexaltavit et honoravit [...]. Epist. 257, p. 414, lin. 23.

20 The implications of gratia are summarised in Wallace-Hadrill 1975, p. 190.

21 Another example of the same use of "power" can, for instance, be found in Epist. 41, where Alcuin writes: “ $\ldots$ and blessed is the people that is exalted by a ruler of such a kind and fortified by such a public preacher; and each of both: the sword of triumphal power vibrates in the right hand ...." (“... et beatus populus tali rectore exaltatus et tali praedicatore munitus; et utrumque: et gladium triumphalis potentiae vibrat in dextera ....") Epist. 41, p. 84, lin. 12.

22 Quid igitur, quid agendum est vestrae Deo devotissimae sollicitudini, tempore serenitatis et pacis [...]. Epist. 257, p. 414, lin. 27.

23 In his comments on Alcuin's conception of peace in Epist. 257, P. Kershaw makes reference to the imperial duties set out by Alcuin. Kershaw 2011, p. 153. In particular, he evaluates Alcuin's “... perception of Charlemagne's duties in a time of peace.” Ibid. He fails to notice, however, that Alcuin's concept of sapientia and its derivatives have the described religious function and introduce Charlemagne's religious responsibilities as a ruler more than anything else.

24 J. Cavadini demonstrates that Alcuin's manual evidences a clear dependence on Augustine's works and thinking. On Alcuin's use of Augustine's concept of catholica pax ("Catholic peace"), see Cavadini 1991, pp. 127-129. The "Augustinian theology" construed by Alcuin is assessed on pp. 140-141. See also Cavadini's list of sources for the De fide sanctae et individuae Trinitatis on pp. 142-146. Of particular interest to my research is Cavadini's exploration of a certain "editorial technique" Alcuin employs when drawing on Augustine. Cavadini uses the term "reduction" to describe a technique that is characterised by a combination of half or whole sentences quoted 
verbatim and complex paraphrasing. Cavadini explains that "the effect is to reproduce not only the content but the atmosphere or tone of the original as well, yet to do it in scope far reduced from that of the original, and all in such a way that it does not appear to be in a voice different from that of the editor." Ibid., p. 137. Interestingly, the technique comes into play both at the beginning and end of the De fide sanctae et individuae Trinitatis, where Alcuin relies heavily on Augustine. The beginning of the manual is modelled after Chapter 1 of Book IV of Augustine's De trinitate, whereas Alcuin's last chapter is based on the last chapter of the De civitate Dei. Ibid.

$25 \mathrm{Nec}$ videlicet alio quolibet vestrae imperialis maiestatis munere digniorem aestimabam sapientiam: nec alium quemlibet tam excellenti dono in accipiendo aeque dignum putabam, dum principem populi christiani cuncta scire et praedicare quae Deo placeant necesse esse notissimum est. Epist. 257, p. 415, lin. 1.

26 Another correspondence that reflects the value of "wisdom" equally well and in an equal manner is Epist. 177, a letter from Alcuin to Charlemagne written during the summer of 799 that implores the king to intervene in favour of Pope Leo III. It says: "Look what has been done with regard to the apostolic see in the particular city, to the most excellent dignity.

All these are only saved by your judgment; in order that with the most prudent counsel of wisdom, given to you by God, with temperate consideration the things that have to be corrected are corrected, and the things that have to be preserved are preserved; and these which divine piety carried mercifully are raised in praise of that one's name, who healed his slave and freed him from the cursed persecution of infidelity.

In fact, your wisest prudence of mind - while it understands all about what is fitting for which person - in doing good or in punishing should do and perform what pleases God." ("Ecce quid actum est de apostolica sede in civitate praecipua, in dignitate excellentissima.

Quae omnia vestro tantummodo servantur iudicio; ut prudentissimo consilio sapientiae, vobis a Deo datae, temperata consideratione corrigantur quae corrigenda sunt, et conserventur quae conservanda sunt; et quae clementer divina gessit pietas extollantur in laudem nominis illius, qui salvum fecit servum suum et liberavit a persecutione exsecrande infidelitatis.

Vestra vero sapientissima animi prudentia - dum omnia intellegat, quid cui conveniat personae - in benefaciendo sive in vindicando faciat et perficiat quod Deo placeat.") Epist. 177, p. 292, lin. 28-33. Other letters that contain the concept of "wisdom" are, for instance, Epist. 249, Epist. 148 and Epist. 111. In Epist. 249, Alcuin states: "How I always praised to wonderfully thrive in the vigour of your Charlemagne's wisdom ...." ("Quam semper agnovi in animo sapientiae vestrae mirabiliter vigere ....") Epist. 249, p. 404, lin. 3. In Epist. 148, Alcuin first maintains, after thanking the king for the gifts Fredegysus brought to him: "In these gifts I both recognised the love towards me as well as considered the wisdom within you ...." ("In quibus utrumque et dilectionem agnovi in me et sapientiam consideravi in te ....") Epist. 148, p. 237, lin. 30. Later on he observes: "Such deliberations, most loved and sweetest David, I have to write to you - not to any countrymen - in which I know your learned wisdom lies and of which I know they please you totally, in order that your mind takes pleasure in the calculations of things, just as mine is very glad rather often to lay such things out to you." ("Tales rationes, dilectissime et dulcissime David, vobis mihi scribendae sunt - non rusticis quibuslibet - in quibus sapientiam tuam eruditam esse scio et quae tibi placere omnino agnosco, ut gaudeat mens tua in rationibus rerum, sicut mea multum gaudet tibi saepius talia dirigere.") Epist. 148, p. 241 , lin. 1. The religious function of "wisdom" is particularly well expressed in Epist. 111, which was forwarded to the treasurer Megenfried. Alcuin says of Charlemagne, who is referred to as David: "For all these things my esteemed David knows best, to 
whom God gave both wisdom and good will; so that he might convert most peoples to the love and praise of Christ.

To him all goodness and power to do good sufficed, except only for one thing on account of the dangerous times of this era: that he has fewer assistants in the work of God than necessary.

Nevertheless, no one in the world, as I believe, has better ones than him.

These he should instruct, admonish and teach according to the wisdom given to him by God." ("Scit enim haec omnia optime dilectus meus David, cui Deus et sapientiam dedit et bonam voluntatem; ut plurimos convertit populos ad caritatem Christi et laudem.

Cui omnis bonitas et potentia ad benefaciendum sufficit, nisi unum tantummodo propter tempora periculosa huius saeculi: quod rariores habet adiutores in opere Domini, quam necesse sit.

Nullus tamen in mundo meliores, ut credo, habet quam ille.

Hos erudiat, ammoneat, et doceat secundum sapientiam sibi a Deo datam.”) Epist. 111, p. 161, lin. 13-18.

27 Multa est omnibus fidelibus in vestra pietate gloriandi facultas, dum clementiae vestrae sollicitudo sacerdotalem, ut decet, habet in praedicatione verbi Dei vigorem, et perfectam in catholica fide scientiam et sanctissimam pro omnium salute devotionem. Epist. 257, p. 415, lin. 26.

28 ... necnon, ut convincerem eos, qui minus utile aestimabant vestram nobilissimam intentionem dialecticae disciplinae discere velle rationes, quas beatus Augustinus in libris de sancta Trinitate adprime necessarias esse putavit, dum profundissimas de sancta Trinitate quaestiones, non nisi categoriarum subtilitate explanari posse probavit. Ibid., p. 415 , lin. 6 .

29 On Alcuin's pseudonyms and understanding of social relationships, see Garrison 1998, pp. 59-79. On the Carolingian idea of the Old Testament kings under Charlemagne and his successors, see Wallace-Hadrill 1971, pp. 99f.; Wallace-Hadrill 1975, pp. 184-191.

30 Fleckenstein 1967, pp. 43-46. Wallace-Hadrill correctly notes that the title of patricius Romanorum meant “... protection for Rome and her patrimony.” WallaceHadrill 1971, p. 100.

31 Charlemagne's choice of Aachen as principal residence after 794 is discussed in Nelson 2001, pp. 217-241.

32 Fleckenstein 1967, p. 45.

33 A detailed study of Charlemagne's permanent entourage at Aachen is Nelson 1998, pp. 177-191. For a definition of Carolingian 'courts' and 'assemblies', see Eichler 2011, pp. 121-148. The Carolingian 'court' in the interplay between 'centre' and 'periphery' is discussed in Stieldorf 2011, pp. 223-245. The term Personenverband with reference to the 'court' as a social structure relying on proximity to the ruler is examined in Depreux 2015, pp. 137-164. The role of the 'court' in Carolingian art is explored in Crivello 2015, pp. 653-666.

34 Fleckenstein 1967, p. 45.

35 For further reading on the evocation of early medieval rulers as David and Solomon, see Kershaw 2011, pp. 2-8, 50-61, 81-124, 128-147, 180-196.

36 Arquillière 1934.

37 Epist. 41, pp. 84-85.

38 At the beginning of Epist. 148 in his address to Charlemagne, who is referred to as King David, Alcuin also presents the king as chosen and loved by God. Epist. 148, p. 237, lin. 27.

39 Beata gens, cuius est dominus Deus eorum: et beatus populus tali rectore exaltatus et tali praedicatore munitus; et utrumque: et gladium triumphalis potentiae vibrat in dextera et catholicae praedicationis tuba resonat in lingua. Epist. 41, p. 84, 
lin. 12. See Anton's “... Verbindung von Schwert und Predigt ...”. Anton 1968, p. 109.

40 Ita et David olim praecedentis populi rex a Deo electus et Deo dilectus et egregius psalmista Israheli victrici gladio undique gentes subiciens, legisque Dei eximius praedicator in populo extitit. Epist. 41, p. 84, lin. 14.

41 This is in line with Wallace-Hadrill 1971, p. 102.

42 Cuius eximia filiorum nobilitate in salute mundi, de virga flos campi et convallium floruit Christus, qui istis modo temporibus ac eiusdem nominis, virtutis et fidei David regem populo suo concessit rectorem et doctorem.

Sub cuius umbra superna quiete populus requiescit christianus, et terribilis undique gentibus extat paganis. Epist. 41, p. 84, lin. 17-19.

43 Ganshof 1949, pp. 14-15.

44 Epist. 217, pp. 360-361.

45 Ibid., p. 360, lin. 35-37.

46 Ibid., p. 360 , lin. 38.

47 Unde, dilectissime fili, faciens facito iustitias et misericordias in populo christiano; quia haec sunt, Salomone adtestante, quae exaltant solium regni, et laudabilem Deoque placabilem regiam efficiunt potestatem. Ibid., p. 361, lin. 6.

48 Non sunt tibi exempla longe quaerenda.

Habes enim in domo, in qua nutritus fuisti, optima totius bonitatis exempla. Ibid., p. 361 , lin. 15 .

49 Et crede certissime illius excellentissimi et omni decore nobilissimi patris tui, rectoris et imperatoris populi christiani, benedictionem te consequi, Deo donante, si nobilitatis illius et pietatis et totius modestiae mores imitari nitaris; Dominique misericordiam, quae melior est totius saeculi gloria, plenissime promereri. Ibid., p. 361, lin. 16.

50 Cf. Wallace-Hadrill: "Charlemagne does not need a mirror of princes; he is himself one." Wallace-Hadrill 1971, p. 103.

51 Epist. 177, pp. 292-293.

52 Ibid., p. 292, lin. 9.

53 Quibus tuam beatitudinem omnibus necessarium est votis exaltare, intercessionibus adiuvare, quatenus per vestram prosperitatem christianum tueatur imperium, fides catholica defendatur, iustitiae regula omnibus innotescat. Ibid., p. 292, lin. 25.

54 ... clarissimisque vestrae nobilitatis filiis benedictio copiosa per vestra benefacta adcrescat; sicut per solius omonymi tui David Deo dilectissimi regis sanctitatem legitur omnibus nepotibus suis regalis throni potestas conservata fuisse. Ibid., p. 293, lin. 10.

55 Civ. XIX 21, p. 391, XIX 23, p. 399.

56 Alcuin's idea of justice is outlined in Kershaw 2011, pp. 149-150.

57 Beata gens, cuius est dominus Deus eorum. Epist. 41, p. 84, lin. 12.

58 By 'Augustinian', I refer to the thought that is manifested in Augustine's later work in particular the De civitate Dei.

59 Epist. 174, p. 288, lin. 26.

60 Here I mean "peace" in its divine sense: vera pax, which is also identified by Kershaw as Augustine's "true peace” or “perfect peace.” Kershaw 2011, pp. 67, 148-153. Kershaw, however, highlights the need for caution when considering Augustine's influence on Alcuin's ideas of peace. Ibid., p. 150. He draws attention to the variety of concepts of pax that Alcuin deployed in his writing. Ibid., pp. 150-151. Clearly, depending on the type of writing, Augustine also had to employ different concepts of pax. What is important for purposes of my research, however, is that Alcuin makes it clear time and again in his address to the Carolingian rulers that Charlemagne and his sons are capable of bringing about vera pax in Augustine's sense. This is supported even by Kershaw 2011, p. 152. Wallace-Hadrill is again more cautious in his reading of Alcuin's conception of pax. Wallace-Hadrill 1971, p. 104. He simply writes that 
for Alcuin pax "... is the condition achieved by a people that is God-centred ..." and relates Alcuin's pax to Augustine's representations in the De civitate Dei of the imperator felix. Ibid. The pax of the imperator felix, however, is without question "peace" in its natural sense. Augustine's influence on Alcuin's Paxidee is furthermore confirmed by Anton 1968, pp. 99-101. In view of the prominence of the concept of pax (and its derivatives, notably pacificus) in Alcuin's letters to the ruler(s), Kershaw is probably right to assume that, although "... there was almost certainly no single impetus ..." behind the strong emphasis upon peace at Charlemagne's court in the 780 s and 790 s, "... its particularly political application ... may have come from Alcuin and his circle." Kershaw 2011, pp. 141, 145.

61 Dum vestrae potentiae gloriosam sublimitatem non periturae Chaldeis flammis Hierusalem imperare scio, sed perpetuae pacis civitatem pretioso sanguine Christi constructam regere atque gubernare, cuius lapides vivi de caritatis glutino colliguntur et caelestis aedificii ad altitudinem ex diversis virtutum gemmis muri consurgunt .... Epist. 198, p. 327, lin. 2.

62 R. Le Jan argues that the production of a Christian ideal, which had its roots in the patristic tradition, led to the emergence of a pre-Carolingian type of Christian kingship in the early seventh century. She adds that "la représentation du peuple franc comme le nouvel Israël et de ses victoires comme le signe de son élection divine n'apparaît que dans la seconde moitié du VIIIe siècle.” Le Jan 2015, pp. 173f. For further reading on Carolingian ceremonies and their inherent symbolism of order and dynamics of competition see ibid., pp. 167-194. On the other hand, Wallace-Hadrill writes of the Carolingian perception of kingship and empire in the ninth century: "what could happen in the Old Israel could equally happen in its successor, the New Israel." This clearly did not yet apply under Charlemagne. Wallace-Hadrill 1971, p. 125.

63 Epist. 198, p. 327, lin. 2.

64 Epist. 139, pp. 220-222.

65 On Alcuin's use of Philistia as the antithesis of Francia and the evocation of Charlemagne as the peaceful King Solomon, see Kershaw 2011, p. 146.

66 One might assume that Moses here alludes to Charlemagne, since Moyse was one of the pseudonyms Alcuin used for him. Fleckenstein 1967, pp. 43-46. However, this might just be a figure of speech Alcuin avails himself of when he refers to the act of praying. In Epist. 93, a letter addressed to Pope Leo III (written by Alcuin on behalf of Charlemagne), the figure "elevatis ad Deum cum Moyse manibus" appears instead of "elevatis cum Moyse manibus in caelum" when Alcuin compares the responsibilities of the pope to those of the king. Since Epist. 93 is composed in Charlemagne's name, Moses cannot represent Charlemagne there. Epist. 93, p. 137, lin. 34.

67 Sed tuum est, pastor electe gregis et custos portarum civitatis Dei, qui clavem Daviticae potentiae dextera tenes, et quinque lapides limpidissimos laeva recondis, blasphemantes exercitum Dei viventis Philistaeos in superbissimo Goliath uno veritatis ictu totos conterere.

Nostrum est elevatis cum Moyse manibus in caelum, humilitatis precibus te adiuvare et spectare cum David in munitissima civitatis turre, donec speculator ex alto culminis fastigio clamitans nobis tuam adnunciet victoriam.

Ad te omnium aspiciunt oculi aliquid de tuo affluentissimo eloquio caeleste desiderantes audire: et ferventissimo sapientiae sole frigidissimos grandinum lapides, qui culmina sapientissimi Salomonis ferire non metuunt, per te citius resolvi spectantes. Epist. 139, p. 221, lin. 34-p. 222, lin. 3.

68 In his investigation of Alcuin's theological conception of pax ("peace"), Anton notes: "Haeresien und Schismata verhindern den wahren Frieden; wie für Augustin ist für Alcuin der Haeretiker der Feind des Friedens." Anton 1968, p. 100.

69 Garrison 2000, pp. 114-161. 
70 Ibid., pp. 122-123.

71 Ibid., pp. 120, 123.

72 Ibid., pp. 122, 153-161.

73 Ibid., pp. 156-161.

74 Epist. 229, pp. 372-374.

75 Garrison 2000, pp. 159. She uses "blessed" when referring to Plat. Rep. 5.473e, although Plato's verb is $\varepsilon \dot{v} \delta \alpha u$ ov $\tilde{\omega}$, which means "I am prosperous/well off/truly

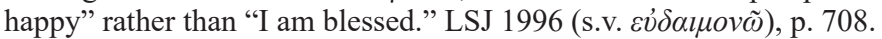

76 Beata gens, cui divina clementia tam pium et prudentem previdebat rectorem.

Felix populus, qui sapiente et pio regitur principe; sicut in illo Platonico legitur proverbio dicente felicia esse regna, si philosophi, id est amatores sapientiae, regnarent, vel reges philosophiae studerent.

Quia nihil sapientiae in hoc mundo conparari poterit. [...]

Quia solummodo vera est sapientia, quae beatos aeternos efficiet dies. Epist. 229, p. 373, lin. 1-7.

77 Ps 32:12.

78 Ps 143:15.

79 Garrison 2000, pp. 160.

80 Ibid.

81 Garrison 2000, pp. 161.

82 Epist. 41, pp. $84-85$.

83 Ibid., p. 84, lin. 12.

84 Ibid., p. 84, lin. 14.

85 Epist. 110, p. 157, lin. 1.

86 Ibid., pp. 157-159.

87 DOMINO EXCELLENTISSIMO ET IN OMNI CHRISTI HONORE DEVOTISSIMO CAROLO, REGI GERMANIAE GALLIAE ATQUE ITALIAE, ET SANCTIS VERBI DEI PRAEDICATORIBUS HUMILIS SANCTAE MATRIS ECCLESIAE FILIOLUS ALBINUS AETERNAE GLORIAE IN CHRISTO SALUTEM. Ibid., p. 157, lin. 1.

88 There is at least one other instance in Epist. 110 that reflects Charlemagne's role as an accomplisher of God's will.

89 In support of my argument, see the useful summary by Wallace-Hadrill on the obligations of Charlemagne as a Christian sovereign ruling over a Christian people. Wallace-Hadrill 1975, pp. 188-190.

90 Gloria et laus deo Patri et domino nostro Iesu Christo, quia in gratia sancti Spiritus - per devotionem et ministerium sanctae fidei et bonae voluntatis vestrae - christianitatis regnum atque agnitionem veri Dei dilatavit, et plurimos longe lateque populos ab erroribus impietatis in viam veritatis deduxit. Epist. 110, p. 157, lin. 5.

91 Sed quia electio necdum in illis divina fuisse videtur, remanent huc usque multi ex illis cum diabolo damnandi in sordibus consuetudinis pessime. Ibid., p. 157, lin. 14.

92 Qualis erit tibi gloria, o beatissime rex, in die aeternae retributionis, quando hi omnes, qui per tuam bonam sollicitudinem ab idolatriae cultura ad cognoscendum verum Deum conversi sunt, te ante tribunal domini nostri Iesu Christi in beata sorte stantem sequentur et ex his omnibus perpetuae beatitudinis merces augetur. Ibid., p. 157, lin. 8 .

93 Auerbach 1958, pp. 83-88. Other sources for Einhard's Vita Karoli Magni were Cicero and possibly Tacitus. See De Jong 2009, pp. 67-69. Suetonius and Cicero are also mentioned in Ganz 2005, p. 40.

94 Auerbach 1958, pp. 83-84.

95 Civ. XI 1, pp. 461-462.

96 AL vol. 1 1986-1994, p. 958.

97 Bullough 2004, p. 451.

98 Epist. 76, p. 118, lin. 13. 
99 Caritas vero inter amicos melior est auro et fides inter absentes praetiosior gemmis .... Ibid., p. 118, lin. 16. For the notion of fides as a key element in relations between members of the Carolingian elite, see Le Jan 1995, pp. 77-81.

100 Bullough, by contrast, considers this writing to be an unemotional request for prayers linked with thanks for gifts received. Bullough 2004, p. 451.

$101 \ldots$ multum laetati sumus de prosperitate vestra .... Epist. 76, p. 118, lin. 14.

102 Here an allusion is made to the Parable of Talents in the New Testament. Mt 25:14 30, Lk 19:11-27. Even though the parable in Matthew involves a secular master and his servants, and the parable in Luke tells of a man of noble descent (who leaves to a foreign country with the intention of becoming a king) and of his servants, I here translate dominicae pecuniae talenta in a spiritual sense as "the talents of godly wealth," because the letter is addressed to a cleric.

103 Vos quod vestrum est diligentissime exsequimini et accepta dominicae pecuniae talenta multiplicate ....

Nunc tempus est laborandi, tunc quiescendi; nunc promerendi, tunc remunerandi.

Fac ut sis, ut tibi veniat quod vis.

Dilige diligentem te, quatenus ad beatissimam illius sessionem pervenire merearis et dicere: "Sicut audivimus, ita et vidimus in civitate Dei nostri," in qua est tota felicitas et nulla perturbatio, summa requies et sempiterna beatitudo. Epist. 76, p. 118, lin. $18-22$.

104 Ps 48:9.

105 Alcuin refers to the bishop's place of residence as the patria ("fatherland"). Epist. 89, p. 133 , lin. 17.

106 Ibid., p. 133, lin. 14. See Bullough 2004, p. 86.

107 Obsecro, ut has litteras alterius cartule iubeatis dirigere ad fratrem vestrum ill. episcopum. Ibid., p. 133, lin. 15. See Bullough 2004, p. 86.

108 Multum me laetificavit ill. presbiter de ... desiderio, quod habetis de salute patrie habitantiumque in ea. Epist. 89, p. 133, lin. 17.

109 Hoc est ... opus vestrum, haec est merces vestra, haec laus et gloria vobis sempiterna, ut praedicetis verbum Dei ... cum magna fiducia. Ibid., p. 133, lin. 19.

110 Nullum gladium timentes, quanto magis nec linguas vaniloquas, que sibi cum divite purpurato flammas incendere probantur. Ibid., p. 133, lin. 21.

111 Vos vero, verbi Dei doctores, parate vobis locum letitiae, non dico in sinu Abrahae, sed in domini Salvatoris aeterna beatitudine, quo translatus est idem pius patriarcha cum omnibus prioris seculi sanctis. Ibid., p. 133, lin. 22.

112 Sternite cum apostolis vestimentis vestris viam asino Christi, ut plano pede illum portans pergat ad Ierusalem, non Romanis manibus destruendam, sed animabus sanctorum perpetuo construendam this figure of speech again hints at verse 9 of Psalm 48, quo me vobiscum, meritis non confidentem, precibus pietatis vestrae, gratia donante divina, deducite, ubi pariter dicamus: "Sicut audivimus, ita et videmus in civitate Dei nostri, gloriosa dicta sunt de te; civitas Domini est pax perpetua mihi virtute tua et abundantia totius letitiae in turribus tuis." Ibid., p. 133, lin. 25.

113 Ps 48:9.

114 Ps 87:3.

115 Ps 48:13.

116 Ps 46:5-6.

117 Civ. XI 1, p. 461, 11. 12, 15-17.

118 AL vol. 1 1986-1994, p. 958.

119 Civ. XI 1, p. 461; AL vol. 1 1986-1994, p. 958.

120 Civ. XI 1, p. 462.

121 For further reading on the working mechanisms of aristocratic loyality to the Carolingian House, see Airlie 1998, pp. 129-143. 


\section{Alcuin of York}

122 ... neque aliam esse veram sapientiam, nisi quae humano generi secundum dispensationem divinae providentiae caelestis gratia administravit. Epist. 196, p. 323, lin. 28.

123 Regalis palatii arcarius Megenfridus. Epist. 111, p. 159, lin. 22.

124 ... dispensatio vineae Christi, id est ecclesiarum Dei. Ibid., p. 162, lin. 2.

125 Sed Dei misericordia opitulante et gubernante cogitationes voluntatesque nostras, concedat nos optato desiderio ad quaerendum perpetuae prosperitatis salutem convenire secundum suae dispensationis oportunitatem .... Epist. 159, p. 258, lin. 24.

126 Quicquid in domini salvatoris nostri passione diabolica invidia vel Iudaica perfidia gestum esse legitur, hoc totum fuit divine pietatis dispensatio .... Epist. 307, p. 470, lin. 45.

127 Bullough 2004, p. 3.

128 Ad cuius servitii facultatem, divina ut credo iubente dispensatione, ad gloriosum et omni honore nominandum huius regni principem et regem Carolum vocatus adveni .... Epist. 200, p. 332, lin. 24.

129 Prima ergo dispensatio Domini nostri Iesu Christi medicinalis, non iudicialis; nam si primo venisset iudicaturus, neminem invenisset cui praemia iustitiae redderet. Commentaria in sancti Iohannis Evangelium, Epist. ad Gislam et Rodtrudam, col. 890 , lin. 41.

130 Quia quidquid ibi factum est in dispensatione humanae salutis, totum unus Christus egit, unus Filius Dei proprius et perfectus, unus Deus verus et omnipotens .... Commentaria in sancti Iohannis Evangelium, ibid., col. 857, lin. 19.

131 Lk 10:16.

132 Et paulo post: "Qui vos audit, me audit; et qui vos spernit, me spernit; et qui me spernit, spernit eum, qui me misit," et cetera, quae ibi de dispensatione verbi Dei leguntur. Epist. 136, p. 209, lin. 29.

133 Alius est, qui talentum praedicationis accipit; alius sapientiae; alius divitiarum; alius cuiuslibet amministrationis, quidam forte alicuius artificii donum a Deo, horum omnium bonorum dispensatore. Epist. 111, p. 160, lin. 5.

134 Et tu, fidelissime dispensator thesaurorum et servator consiliorum et adiutor devotus, viriliter fac voluntatem illius. Ibid., p. 161, lin. 19.

135 Anton confirms the congruence in form between Augustine and Alcuin's Vita Willibrordi archiepiscopi Traiectensis. Anton 1968, pp. 98-99 (note 117). See Rambridge 2003, pp. 371-381 for further reading on the Vita Willibrordi archiepiscopi Traiectensis and Alcuin's encouragement of continuing missionary effort.

136 Mothers were often said to have had dreams about their unborn sons' careers.

137 Sed ut somnii, Deo dispensante, inpleretur veritas, quod mater olim de eo se vidisse testatur, suae conscius voluntatis, licet adhuc divinae dispensationis ignarus, illas in partes navigare cogitavit et clarissima evangelicae praedicationis luce torpentes longa infidelitate populos, si Dei esset voluntas, inlustrare. Vit.Will., p. 119.

138 In his reflections on the dispensatio (temporalis), C. Müller emphasises that God distributes ('dispensat') his administrators and governors ('dispensatores') to different times and places. Müller 1993, p. 226.

139 Nam prima congregatio, quam Deo dispensante gubernandam accepi, beato Iohanni baptistae consecrata est. Epist. 272, p. 430, lin. 21.

140 Classen 1967, p. 569; Fleckenstein 1990, pp. 59-60.

141 Ibid., p. 56; Classen 1967, pp. 570-571, 579.

142 Ibid., pp. 571, 579; Fleckenstein 1990, p. 56.

$143 \ldots$ id est apostolica sublimitas, quae beati Petri principis apostolorum sedem vicario munere regere solet; quid vero in eo actum sit, qui rector praefate sedis fuerat, mihi veneranda bonitas vestra innotescere curavit. Epist. 174, p. 288, lin. 17.

144 Alia est imperialis dignitas et secundae Romae saecularis potentia; quam impie gubernator imperii illius depositus sit, non ab alienis, sed a propriis et concivibus, ubique fama narrante crebrescit. Ibid., p. 288, lin. 20. 
145 Classen 1967, pp. 566, 579; Fleckenstein 1990, pp. 57-59.

146 Tertia est regalis dignitas, in qua vos domini nostri Iesu Christi dispensatio rectorem populi christiani disposuit, ceteris praefatis dignitatibus potentia excellentiorem, sapientia clariorem, regni dignitate sublimiorem.

Ecce in te solo tota salus ecclesiarum Christi inclinata recumbit.

$\mathrm{Tu}$ vindex scelerum, tu rector errantium, tu consolator maerentium, tu exaltatio bonorum. Epist. 174, p. 288, lin. 22-26.

147 Tempora sunt periculosa olim ab ipsa veritate praedicta, quia refrigescit caritas multorum Mt 24:12.. Ibid., p. 288, lin. 32.

148 This argument is supported by Wallace-Hadrill 1971, p. 101.

$149[\ldots]$ quorum operum merces est aeterna felicitas, cuius dator est Deus solis veraciter piis. Civ. V 26, p. 240, 11. 26-27.

$150 \ldots$ in quibus est etiam quaelibet imperii magnitudo, quam pro temporum gubernatione dispensat. Ibid., p. 240, 11. 30-32.

151 Epist. 178, p. 294.

152 Carm. 1.

153 OLD vol. 1 1968, pp. 843-845; TLL Online 1900-, Lemma/Sublemma, s.v. imperium, $-\bar{\imath} n$.

154 Another derivative of imperare, imperator, which in the Classical Roman Period signified "commander," "commander-in-chief," "(victorious) general" (as a title of honour) and "emperor," even more strongly expresses the term's relation to military affairs. OLD vol. 1 1968, pp. 842-843; TLL Online 1900-, Lemma/Sublemma, s.v. imperātor, -ōris $m$.

155 AL vol. $32004-2010$, p. 140. It should be noted that this notion is here only considered in its plural form due to its different meaning in the singular. Unlike gentes, gens does not have a negative undercurrent. Already, the Hebrew Old Testament generally differentiated between the plural haggojjîm ("non-Jewish/heterodox tribes") and the singular ha'am, which meant the small, elected "people of God" tied by faith and blood bond. The Septuagint further reinforces this opposition, using originally the terms $\varepsilon^{\prime} \theta v \eta$ and $\lambda \alpha o ́ \varsigma$ (corresponding to the Latin gens). Hence, the word gens also appears in the Latin Old Testament with reference to the Jewish nation. As for Augustine, he uses the singular gens when he talks about both the "Jewish people" (gens Iudaeorum) and the "Roman people" (gens populi Romani) (here following Varro). Ibid., pp. 140-142.

156 Ibid., p. 141.

157 Ibid., p. 140.

158 In Latin, gentiles are "pagans" or "heathens," which is evidently derived from gentes, who usually lived in the countryside. This makes sense, considering that Christianity first formed in the cities and country people remained pagan for longer.

159 AL vol. 3 2004-2010, p. 140.

160 Ibid., p. 141.

161 Ibid.

162 Alcuin's use of pax, iustitia and imperium in the poem on York and the question of these concepts' origin in Augustine's thinking are discussed in Kershaw 2011, pp. $148 \mathrm{ff}$.

163 Epist. 178, p. 294, lin. 21.

164 Ibid., p. 294, lin. 21-25.

165 Ibid., p. 294, lin. 26.

166 Ibid., p. 294, lin. 14.

167 Litteras prosperitatis vestrae et consolationis nostrae magno amore et digno favore suscepimus, Dei omnipotentis clementiam conlaudantes, qui vos fidelesque vestros prosperis successibus pollere fecit, et inimicos sui nominis vestrae potentiae subdidit pedibus. 
Hoc enim faciat Deus et hoc addat, ut triumpho terroris vestri inimicas undique subiciat gentes; et suavissimo suae dilectionis iugo in christiana fide ferocissimos subiciat animos, ut solus deus et dominus noster Iesus Christus credatur, colatur, atque ametur.

Vestra clarissima potestas et sanctissima voluntas in hoc omni laboret studio, ut Christi nomen clarificetur et eius divina potestas per fortitudinis vestrae triumphos multis terrarum regnis innotescat .... Ibid., p. 294, lin. 10-17.

168 This is supported by Nelson 1988, p. 230.

169 Contigit autem, Pippinum ducem Francorum diem obire et filium eius Carolum regno patris potiri.

Qui multas gentes sceptris adiecit Francorum, inter quas etiam cum triumphi gloria Fresiam, devicto Rabbodo, paterno superaddidit imperio. Vit.Will., p. 127, lin. 5-6.

170 Baptizavit igitur Pippinum, filium fortissimi Francorum ducis Carli, patrem huius nobilissimi Caroli, qui modo cum triumphis maximis et omni dignitate gloriosissime Francorum regit imperium. ...

Scit namque omnis populus, quibus nobilissimus victor celebratur triumphis, vel quantum terminos nostri dilatavit imperii, vel quam devote christianam in regno suo propagavit relegionem, vel quid pro defensione sanctae Dei ecclesiae apud extraneos exercuit gentes. Ibid., p. 133, lin. 17-p. 134, lin. 2.

171 Epist. 257, pp. 414-416.

172 Ibid., p. 414, lin. 20-p. 415, lin. 12.

173 Ibid., p. 414, lin. 23.

174 Epist. 110, pp. 157-159.

175 Ibid., p. 157, lin. 17.

176 Gentes populosque Hunorum, antiqua feritate et fortitudine formidabiles, tuis suo honori militantibus subdidit sceptris: praevenienteque gratia colla diu superbissima sacrae fidei iugo devinxit et caecis ab antiquo tempore mentibus lumen veritatis infudit. Ibid., p. 157, lin. 18.

177 Epist. 41, pp. 84-85.

178 Ita et David olim praecedentis populi rex a Deo electus et Deo dilectus et egregius psalmista Israheli victrici gladio undique gentes subiciens, legisque Dei eximius praedicator in populo extitit. Ibid., p. 84, lin. 14.

179 Epist. 119, p. 174.

180 Et tu, excellentissime iuvenis, nobilitatem generationis morum nobilitate adornare studeas; et Dei omnipotentis voluntatem atque honorem tota virtute implere contende; quatenus illius ineffabilis pietas solium regni tui exaltet et terminos dilatet, et gentes tuae subiciat potestati. Ibid., p. 174, lin. 10.

$181[\ldots]$ Christi nomen clarificetur et eius divina potestas per fortitudinis vestrae triumphos multis terrarum regnis innotescat [...]. Epist. 178, p. 294, lin. 17.

182 Epist. 202, pp. 335-336.

183 Ibid., p. 336, lin. 20.

184 Carm. 1.

$185[\ldots]$ ut foret emporium terrae commune marisque, et fieret ducibus secura potentia regni, et decus imperii terrorque hostilibus armis [...]. Ibid., p. 170, vers. 19.

$186[\ldots]$ assiduis superans hostilia castra triumphis, imperioque suo gentes superaddidit omnes, [...]. Iamque iugum regis prona cervice subibant

Saxonum populus, Pictus Scotusque, Britannus [...]. Ibid., p. 172, vers. 115-122.

187 Hanc Romana manus muris et turribus altam fundavit primo, comites sociosque laborum indigenas tantum gentes adhibendo Britannas [...]. Ibid., p. 170, vers. 19.

188 Ibid., p. 172. McKitterick, discussing the text and message of the Annales regni Francorum, literally uses the word gentes when referring to the peoples who are 
about to be taken over by the Franks (saying that they will become "appendages to the Franks"). McKitterick 2004, p. 115.

189 Civ. I, IV, V.

190 This is the instance when Augustine adapts Virgil for his own argument and says about the Christian God: "[...] He sets neither limits of government nor time limits,

He will give an Empire without end." ("[...] nec metas rerum nec tempora ponit,

Imperium sine fine dabit.") Civ. II 29, p. 96, 11. 7-8. The passage is given greater consideration under Terminology for Types of Politically Organised Communities in Concepts of Augustinian Political Thought, the third chapter of Part I.

191 Civ. I 30, p. 47, I 36, p. 52, II 17, p. 73, II 20, p. 79, IV 2, p. 148, IV 5, p. 151, V 1, p. 190, V 18, pp. 227, 228, XX 19, p. 450.

192 Civ. IV 6, p. 152, XIX 7, p. 366.

193 Civ. XIX 7, pp. 366-367.

194 Ibid., p. 366, 1. 28.

195 Ibid., p. 366, 1. 19.

196 Civ. I 36, p. 52, IV 2, p. 147, IV 7, p. 153, IV 15, p. 165, IV 29, p. 182, V 12, pp. 211 , 214, 215, 216, V 15, p. 220, XII 3, p. 515.

197 Civ. I 23, p. 38, I 26, p. 41, IV 26, p. 178, V 18, p. 224, XII 26, p. 553.

198 Civ. V 12, p. 213, 1. 28.

199 Bullough 1999, pp. $42 \mathrm{f}$.

200 Ibid., p. 42.

201 Ibid.

202 McKitterick 2004, p. 115. She furthermore holds that, especially in the Frankish annals, where the Franks establish their descent as a gens and construct their own history, imperium appears in the sense of "rule of the Franks over many peoples." Ibid., p. 118. Nelson 1988, p. 230.

203 Ganshof 1949.

204 Ibid., pp. 10-28.

205 Ibid., pp. 9-10.

206 Ibid., p. 11.

207 Ibid., pp. 12-13.

208 Ibid., pp. 11, 14.

209 Ibid., pp. 12-13. However, as noted by Ganshof, H. Hirsch has shown that already in the late eighth century the term imperium Christianum emerged in liturgy as an attribute of the Carolingian king. Ibid., p. 10.

210 Ibid., p. 22.

211 Ibid., p. 17.

212 Ibid., pp. 14-15.

213 Ibid., p. 15. See also Wallace-Hadrill 1971, pp. 101-103.

214 Epist. 185, 202, 234. Ganshof 1949, p. 15.

215 Ibid.

216 Wallace-Hadrill specifies that Alcuin's ideas "[...] belonged to the insular tradition of the interpretation of kingship [...]" and "[...] were rooted in the Bible, in PseudoCyprian's Twelve Abuses, and in Isidore." Wallace-Hadrill 1971, pp. 100-101. On Pseudo-Cyprian's and Isidore's influences on Alcuin see Anton 1968, pp. 93, 101, 103, 107. The Old Testament, in particular, was relevant to Alcuin's perception of kingship. Wallace-Hadrill 1971, p. 105. The argument of these scholars is plausible in light of our finding that Isidore drew his idea of imperium from Augustine.

217 Ganshof 1949, pp. 12-13.

218 Ibid., p. 13.

219 Here I refer to Wallace-Hadrill's study, the argument of which about the search for the main characteristics and elements of influence on the Carolingians' idea of kingship and their understanding of the association between God and the ruler is only partly convincing. Wallace-Hadrill 1975 . While the point that the Carolingian age 
remained vague "[...] about its heritage of "Germanic' kingship" is probably the most cogent part in his narrative on pp. 181-185, Wallace-Hadrill is not clear about how exactly the different elements of influence are to be assembled in order to yield the "Carolingian" conception of kingship. On p. 183, Wallace-Hadrill refers to the Greek or Byzantine ideas of "divine kingship," while on p. 185 reference is made to the Old Testament idea of the divinely ordained king. The Greek notion of "divine kingship" and the Old Testament "kingship ordained by God," however, are two entirely different categories. In Wallace-Hadrill's analysis, neither of them is distinctly defined in relation to the Carolingian conception of kingship. Statements such as "the idea of the personal sanctity of the ruler [...] comes straight from the Old Testament" are thus vague and inaccurate. Ibid., p. 185.

220 Civ. II 5, p. 58, IV 7, p. 153, V 12, p. 211, V 15, p. 221, XVIII 22, p. 284.

221 Hinc est et illud eiusdem poetae, quod, cum artibus aliarum gentium eas ipsas proprias romanorum artes regnandi atque imperandi et subiugandi ac debellandi populos anteponeret, ait: excudent alii spirantia mollius aera,

cedo equidem, uiuos ducent de marmore uultus,

orabunt causas melius caeli que meatus

describent radio et surgentia sidera dicent:

tu regere imperio populos, romane, memento

(hae tibi erunt artes) paci que inponere mores,

parcere subiectis et debellare superbos. Civ. V 12, p. 213, 11. 20-30.

222 Ibid., p. 213.

223 Nam in omnibus fere gentibus quodam modo uox naturae ista personuit, ut subiugari uictoribus mallent, quibus contigit uinci, quam bellica omnifariam uastatione deleri.

Hinc factum est, ut non sine dei prouidentia, in cuius potestate est, ut quisque bello <aut $>$ subiugetur aut subiuget, quidam essent regnis praediti, quidam regnantibus subditi.

Sed inter plurima regna terrarum, in quae terrenae utilitatis uel cupiditatis est diuisa societas (quam ciuitatem mundi huius uniuersali uocabulo nuncupamus), duo regna cernimus longe ceteris prouenisse clariora, assyriorum primum, deinde romanorum, ut temporibus, ita locis inter se ordinata atque distincta.

Nam quo modo illud prius, hoc posterius: eo modo illud in oriente, hoc in occidente surrexit; denique in illius fine huius initium confestim fuit.

Regna cetera ceteros que reges uelut adpendices istorum dixerim. Civ. XVIII 2, p. 257, 11. 2-17.

224 See e.g. Leyser 2012, p. 453.

225 Even though this passage is only one among several possible examples, it is illustrative of how Augustine's political reflections were transmitted from Late Antiquity into the Early Middle Ages. To provide a more comprehensive overview of the transmission of Augustine's texts and ideas would, however, be beyond the scope of this research.

226 Civ. V 12, p. 212.

227 DE REGNIS MILITIAE QVE VOCABVLIS.

Regnum a regibus dictum.

Nam sicut reges a regendo uocati, ita regnum a regibus.

Regnum uniuersae nationes suis quaeque temporibus habuerunt, ut Assyrii, Medi, Persae, Aegyptii, Graeci, quorum uices sors temporum ita uolutauit ut alterum ab altero solueretur.

Inter omnia autem regna terrarum duo regna ceteris gloriosa traduntur: assyriorum primum, deinde Romanorum, ut temporibus, et locis inter se ordinata atque distincta.

Nam sicut illud prius et hoc posterius, ita illud in oriente, hoc in occidente exortum est: denique in illius fine huius initium confestim fuit.

Regna cetera ceteri que reges uelut adpendices istorum habentur. Etym., Cl. 1186, lib.: 9, cap.: 3, par.: 1-3. See also Étymologies 1983- and Barney et al. 2006. 
228 Epist. 202, p. 336, lin. 20.

229 Ibid., pp. 335-336.

230 Civ. I 36, p. 52, 1. 14, IV 2, p. 148, 11. 14-15.

231 Civ. V 12, p. 211, 1. 13.

232 On the transmission of Augustine's texts in the Early Middle Ages, see Leyser 2012.

233 Bullough 1999, pp. 42-43.

234 AL vol. 3 2004-2010, p. 144.

235 Ibid., p. 141.

236 Ibid., p. 144.

237 Epist. 178, p. 294, lin. 14.

238 Civ. XVIII 2, p. 257, 3, pp. 259-260.

239 Civ. XVIII 27, p. 292.

240 Garrison 2000, pp. 160.

241 Civ. I 23, p. 38, I 26, p. 41, IV 26, p. 178, V 18, p. 224, XII 26, p. 553.

242 Caesarum nomen a Iulio coepit, qui bello ciuili commoto primus Romanorum singularem optinuit principatum.

Caesar autem dictus, quod caeso mortuae matris utero prolatus eductus que fuerit, uel quia cum caesarie natus sit.

A quo et imperatores sequentes Caesares dicti, eo quod comati essent.

Qui enim execto utero eximebantur, Caesones et Caesares appellabantur.

Iulius autem dictus, quia ab Iulo Aeneae filio originem duxit, ut confirmat Vergilius: Iulius, a magno demissum nomen Iulo.

Imperatorum autem nomen apud Romanos eorum tantum prius fuit apud quos summa rei militaris consisteret, et ideo imperatores dicti ab imperando exercitui: sed dum diu duces titulis imperatoriis fungerentur, senatus censuit ut Augusti Caesaris hoc tantum nomen esset, eo que is distingueretur a ceteris gentium regibus; quod et sequentes Caesares hactenus usurpauerunt.

Solet enim fieri ut primi regis nomen etiam reliqui possideant, sicut apud Albanos ex Siluii nomine omnes reges Albanorum Siluii appellati sunt; sicut apud Persas Arsacidae; apud Aegyptios Ptolomei; apud Athenienses Cecropidae.

Augustus ideo apud Romanos nomen imperii est, eo quod olim augerent rempublicam amplificando. Quod nomen primitus senatus Octauio Caesari tradidit, ut quia auxerat terras, ipso nomine et titulo consecraretur.

Dum autem idem Octauianus iam Caesar et imperator appellaretur, uel Augustus, postea uero dum ludos spectaret, et pronuntiatum esset illi a populo ut uocaretur et Dominus, statim manu uultu que auerso indecoras adulationes repressit et Domini appellationem ut homo declinauit, atque insequenti die omnem populum grauissimo edicto corripuit, Dominum que se post haec appellari ne a liberis quidem suis permisit.

Fuit autem filius A[c]tiae, quae nata est de sorore Iulii Caesaris. Etym., Cl. 1186, lib.: 9, cap.: 3, par.: 12-17.

243 Bullough 1999, p. 41.

\section{Bibliography}

\section{Primary sources}

Alcuinus: Carmina. Ernst Dümmler (ed.) (MGH AN Poet. Lat. 1). Berlin, 1881.

Alcuinus: De pontificibus et sanctis ecclesiae Eboracensis. Peter Godman (ed.). Oxford, 1982.

Alcuinus: Epistolae. Ernst Dümmler (ed.) (MGH Epp. 4). Berlin, 1895.

Alcuinus: Vita Willibrordi archiepiscopi Traiectensis. Bruno Krusch and Wilhelm Levison (eds.) (MGH SS rer. Merov. 7). 1920, 113-141. 
Augustinus Hipponensis: Sancti Aurelii Augustini episcopi De civitate Dei libri XXll 2 vols. Bernhard Dombart et Alfons Kalb (recogn.). (5th ed.). Stuttgart, 1993.

Barney, Stephen A. et al.: The Etymologies of Isidore of Seville. With the collaboration of Muriel Hall. Cambridge, 2006.

Isidorus Hispalensis: Etymologiarum sive originum libri XX. Wallace Martin Lindsay (ed.) (LLT-A). Oxford, 1911.

Hispalensis, Isidorus: Étymologies. (Auteurs latins du Moyen Âge). Paris, 1983.

Tullius Cicero, Marcus: De re publica; De legibus; Cato maior de senectute; Laelius de amicitia. J. G. F. Powell (recogn. brevique adnotatione critica instruxit). Oxford and New York, 2006.

Vergilius Maro, Publius: Aeneis. Gian Biagio Conte (recensuit atque apparatu critico instruxit). Berlin, 2009.

\section{Secondary sources}

Airlie, Stuart: "Semper Fideles"? Loyauté envers les Carolingiens comme constituent de l'identité aristocratique, in: RégineLe Jan (ed.): La royauté et les élites dans l'Europe carolingienne (début Ixe siècle aux environs de 920). Villeneuve d'Ascq, 1998, 129-143.

Anton, Hans Hubert: Fürstenspiegel und Herrscherethos in der Karolingerzeit. Bonn, 1968.

Arquillière, H.-X.: L'Augustinisme politique: Essai sur la formation des théories politiques du Moyen-Âge. Paris, 1934.

Auerbach, Erich: Literatursprache und Publikum in der lateinischen Spätantike und im Mittelalter. Bern, 1958.

Bullough, Donald A.: Die Kaiseridee zwischen Antike und Mittelalter, in: Christoph Stiegemann and Matthias Wemhoff (eds.): Kunst und Kultur der Karolingerzeit: Karl der Grosse und Papst Leo III. in Paderborn: Beiträge zum Katalog der Ausstellung, Paderborn 1999. Mainz, 1999, 36-46.

Bullough, Donald A.: Alcuin: Achievement and Reputation: Being Part of the Ford Lectures Delivered in Oxford in Hilary Term 1980. Leiden, 2004.

Cavadini, John: The Sources and Theology of Alcuin's De Fide Sanctae et Individuae Trinitatis. Traditio 46, 1991, 123-146.

Classen, Peter: Karl der Grosse: das Papsttum und Byzanz, in: Helmut Beumann (ed.): Persönlichkeit und Geschichte, Karl der Grosse: Lebenswerk und Nachleben Vol. 1. (3rd ed.) Düsseldorf, 1967, 537-608.

Crivello, Fabrizio: Il ruolo della corte nell'arte carolingia. Le testimonianze dei manoscritti miniati. Le corti nell'alto medioevo Settimane 62, Spoleto 2015, 653-666.

Davis, Jennifer R.: Charlemagne's Settlement of Disputes, in: Matthias Becher and Alheydis Plassmann (eds.): Streit am Hof im frühen Mittelalter Super alta perennis: Studien zur Wirkung der Klassischen Antike XI, 2011, 149-173.

De Jong, Mayke: The Penitential State: Authority and Atonement in the Age of Louis the Pious, 814-840. Cambridge, 2009.

Depreux, Philippe: Der karolingische Hof als Institution und Personenverband. Le corti nell'alto medioevo Settimane 62, Spoleto 2015, 137-164.

Dodaro, Robert: Church and State, in: Allan Fitzgerald (ed.): Augustine Through the Ages: An Encyclopedia. Grand Rapids, Michigan, 1999, 176-184.

Eichler, Daniel: Karolingische Höfe und Versammlungen - Grundvoraussetzungen, in: Matthias Becher and Alheydis Plassmann (eds.): Streit am Hof im frühen Mittelalter Super alta perennis,: Studien zur Wirkung der Klassischen Antike XI 2011, 121-148. 
Fleckenstein, Josef: Karl der Grosse und sein Hof, in: Helmut Beumann (ed.): Persönlichkeit und Geschichte, Karl der Grosse: Lebenswerk und Nachleben vol. 1. (3rd ed.). Düsseldorf, 1967, 24-50.

Fleckenstein, Josef: Karl der Grosse. (3rd ed.). Göttingen and Zürich, 1990.

Ganshof, François Louis: The Imperial Coronation of Charlemagne: Theories and Facts. Glasgow, 1949.

Ganz, David: Einhard's Charlemagne: The Characterisation of Greatness, in: Joanna Story (ed.): Charlemagne: Empire and Society. Manchester, 2005, 38-51.

Garrison, Mary: The Social World of Alcuin: Nicknames at York and the Carolingian Court, in: Luuk Houwen and Alasdair MacDonald (eds.): Alcuin of York: Scholar at the Carolingian Court. Proceedings of the Third Germania Latina Conference Held at the University of Groningen, May 1995. 4.3, Groningen, 1998, 59-79.

Garrison, Mary: The Franks as the New Israel? Education for an Identity from Pippin to Charlemagne, in: Yitzhak Hen and Mathew Innes (eds.): The Uses of the Past in the Early Middle Ages. Cambridge, 2000, 114-161.

Holtz, Louis: Alcuin et la réception de Virgile du temps de Charlemagne, in: Hermann Schefers (ed.): Einhard: Studien zu Leben und Werk. Darmstadt, 1997, 67-80.

Kershaw, Paul: Peaceful Kings: Peace, Power and the Early Medieval Political Imagination. Oxford, 2011.

Le Jan, Régine: Famille et pouvoir dans le monde franc (VIIe - Xe siècle): Essai d'anthropologie sociale. Paris, 1995.

Le Jan, Régine: Les cérémonies carolingiennes: symbolique de l'ordre, dynamique de la compétition. Le corti nell'alto medioevo Settimane 62, Spoleto 2015, 167-194.

Leyser, Conrad: Augustine in the Latin West, 430-ca. 900, in: Mark Vessey (ed.): $A$ Companion to Augustine. Chichester, 2012, 450-464.

McKitterick, Rosamond: History and Memory in the Carolingian World. Cambridge, 2004.

Meens, Rob: Sanctuary, Penance, and Dispute Settlement under Charlemagne: The Conflict between Alcuin and Theodulf of Orléans over a Sinful Cleric. Speculum 82(2), 2007, 277-300.

Müller, Christof: Geschichtsbewusstsein bei Augustinus: Ontologische, anthropologische und universal-geschichtlich/heilsgeschichtliche Elemente einer Augustinischen "Geschichtstheorie". Würzburg, 1993.

Nelson, Janet Laughland: Kingship and Empire, in: James Henderson Burns (ed.): The Cambridge History of Medieval Political Thought c. 350-c. 1450. Cambridge, 1988, 211-251.

Nelson, Janet Laughland: La cour impériale de Charlemagne, in: Régine Le Jan (ed.): La royauté et les élites dans l'Europe carolingienne (début Ixe siècle aux environs de 920). Villeneuve d'Ascq, 1998, 177-191.

Nelson, Janet Laughland: Aachen as a Place of Power, in: Mayke De Jong et al. (eds.): Topographies of Power in the Early Middle Ages. Leiden, 2001, 217-241.

Rambridge, Kate: Alcuin's Narratives of Evangelism: The Life of St Willibrord and the Northumbrian Hagiographical Tradition, in: Martin Carver (ed.): The Cross Goes North: Processes of Conversion in Northern Europe. York, 2003, 371-381.

Stieldorf, Andrea: Adel an der Peripherie im Streit mit dem höfischen Zentrum, in: Matthias Becher and Alheydis Plassmann (eds.): Streit am Hof im frühen Mittelalter Super alta perennis: Studien zur Wirkung der Klassischen Antike XI, 2011, 223-245.

Wallace-Hadrill, John Michael: Early Germanic Kingship in England and on the Continent: The Ford Lectures Delivered in the University of Oxford in Hilary Term 1970. Oxford, 1971. 
Wallace-Hadrill, John Michael: The Via Regia of the Carolingian Age, in: Idem (ed.): Early Medieval History. Oxford, 1975, 181-200 (first published Oxford 1965, 22-41).

\section{Dictionaries and lexica}

A Greek-English Lexicon: With a Revised Supplement, 1996. Compiled by Henry George Liddell and Robert Scott, revised and augmented throughout by Sir Henry Stuart Jones with the assistance of Roderick McKenzie. (Repr. of the new, 9th ed. Oxford, 1996 Mayer, Cornelius Petrus et al. (eds.): Augustinus-Lexikon vols. 1-4, Doppelfasz. 5/6. Basel, 1986-2017.

Thesaurus Linguae Latinae Online. München, 1900. 


\section{Part III}

\section{Hincmar of Rheims}


$\Longrightarrow$ Taylor \& Francis Taylor \& Francis Group http://taylorandfrancis.com 


\section{Hincmar's direct use of Augustine in the 'Epistolae'}

This third part investigates the significance of Augustine of Hippo in Hincmar of Rheims' ${ }^{1}$ writing. Emphasis is placed on Augustine's political ethics besides political thought. Again, an attempt is made to trace connections to Augustine at different levels of the text. I approach Hincmar's material in two ways: by searching first for explicit and then for implicit evidence of Augustine's influence. To locate the direct and indirect references in the sources, I have used the $e M G H$ and the Patrologia Latina Database.

In this first chapter, I explore all kinds of direct references to Augustine, including the mentioning of his name, citation and quotation. The second chapter examines the implicit evidence of Augustine's influence at two levels: the level of content and the formal level of Hincmar's texts. Prominence is given to the political ethics and political thought contained in the work De civitate Dei. As in the analysis of Alcuin's writing, the formal analysis of Hincmar's sources, which is concerned with Hincmar's use of terminology, complements the content analysis. I focus on a number of identified Augustinian ${ }^{2}$ terms, concepts and figures found in the De civitate Dei, which also occur in the Carolingian sources. I attempt to define the meaning and function of all these terms, concepts and figures in Hincmar's texts, and compare Hincmar's use of them with Augustine's (and, if relevant, also with Alcuin's ${ }^{3}$ ). Particular attention is given to the argument made in the Augustinus-Lexikon. ${ }^{4}$

Among the noteworthy concepts, terms, expressions and figures treated in the formal analysis are the political terms imperare/imperium and gentes/gentilitas; the expressions dilatare and subiugare; the concepts of pax, iustus/iustitia, felix/felicitas and felicitas aeterna, beatus/beatitudo, misericors/misericordia and humilis/humilitas as well as the figures of Old Testament kings (e.g. David and Solomon). I examine the representation of Christian Roman emperors (e.g. Constantine I and Theodosius I), of Charlemagne as well as of leading clerics and theologians who prove relevant in comparisons of selected texts. I show how these terms, concepts and figures appear as clusters in similar contexts in Augustine and Hincmar (and every so often also in Alcuin).

The term sapientia ("wisdom") is not discussed in the analysis of Hincmar's sources for the following reasons: as far as Alcuin's writing is concerned, the term sapientia has revealed itself as meaningful in letters to Charlemagne that have a 
strong instructional component. It features in the author's personal address to the ruler - i.e. at the beginning and end of a letter. Alcuin firstly avails himself of the term sapientia when addressing Charlemagne in order to persuade the emperor to learn and promote the Catholic Christian doctrine (as propagated by Augustine) and to take note of Alcuin's opinion. Secondly, Alcuin exalts Charlemagne above all other secular leaders by claiming that he has gained sapientia besides imperium ("supreme power") or alternatively potestas or potentia ("power"), which together reflect the ruler's religious and political responsibilities of defending and spreading the Catholic Christian faith and defending and enlarging his realm to a higher degree than any past or present ruling figure. In Hincmar's writing, the term sapientia features too. However, Hincmar's use of sapientia - as well as the meaning he applies to it - is less consistent. Alcuin defines sapientia as "the knowledge of divine and human affairs". ${ }^{5}$ Apart from this definition, the consistency with which Alcuin applies this term in his writing allows the reader to attribute to both sapientia and imperium a separate, clear-cut and well-defined meaning relating to Christian political thought. Hincmar's personal addresses, however, proves to be much less original, if not uncreative and repetitive. This is due to the fact that Hincmar never pursued education and learning for their own sake. He mostly absorbed literary knowledge for practical purposes; in consequence, similar ideas recur in different works in similar linguistic form. Moreover, they are usually borrowed from other authors.

The aim of this analysis is to examine different aspects of Augustine's influence on Hincmar's surviving texts. In my study of Hincmar's writing, I concentrate on his Epistolae for different types of explicit references to Augustine and on his Expositiones ad Carolum Regem and De regis persona et regio ministerio for direct as well as indirect references to Augustine. In the Expositiones ad Carolum Regem and the De regis persona et regio ministerio, I focus on references to Augustinian political ethics and political thought in the De civitate Dei.

Hincmar composed more than thirty-seven works in the course of his life. It is not possible to consider all his surviving works in this study. There are at least two other works written by Hincmar that initially seemed suitable for my analysis: the De ordine palatii and the De cavendis vitiis et virtutibus ad Carolum Calvum Regem. The De ordine palatii was composed shortly before Hincmar's death. ${ }^{6}$ It is a memorandum written for King Carloman II of Western Francia between 5 August or 9 September and 21 December 882, following the death of Louis III. ${ }^{7}$ It was recorded under the title Admonitio Hincmari archiepiscopi ad episcopos et ad regem Karolomannum per capitula and became known as the De ordine palatii. $^{8}$ In this work, Hincmar devises principles that should help the young ruler to achieve the reerectio honoris et pacis ecclesiae ac regni. ${ }^{9}$ It cannot be proven that Hincmar had Adalhard of Corbie's libellus de ordine palatii in hand when he composed this 'mirror for princes' ${ }^{10}$ (Adalhard's text is no longer extant). ${ }^{11}$ However, the fact that Adalhard's description of the court of Charlemagne existed and has had an impact on Hincmar's De ordine palatii is no longer a matter for debate. ${ }^{12}$ Hincmar himself mentions the libellus de ordine palatii as a source in his text. ${ }^{13}$ Hincmar's De ordine palatii initially seemed suitable for 
analysis, particularly because of its first part, which is founded on the records he had edited of the Synod of Fismes (881). ${ }^{14}$ While the second part draws on Adalhard's lost work and contains a description of the composition and organisation of the Frankish court as well as of the political administration at the time of Charlemagne, the first part reflects Hincmar's ideas on kingship as a form of worldly government and discusses them in a broader context of world order. ${ }^{15}$ The language and content of this first section are strongly shaped by the sources he draws from - which are the Holy Scriptures and the works of the Fathers. Thus, in the De ordine palatii, linguistic formulations from patristic sources in the first part exist side by side with vernacular elements from the so-called lingua rustica in the second part. What is more, King David and Emperor Constantine I feature in the text. However, R. Schieffer argues that the quotations in the first section are largely drawn from earlier works and that the structure and style corresponds to that found in Hincmar's other texts of admonition. ${ }^{16}$ A closer examination confirms that the De ordine palatii hardly contains any thoughts that are not already expressed in the De regis persona et regio ministerio, where many direct references to the De civitate Dei are made. Hincmar instead draws more on Gregory the Great and (pseudo-) Cyprian. References to the De civitate Dei are rare. ${ }^{17}$ The De cavendis vitiis et virtutibus ad Carolum Calvum Regem is a work on the doctrine of virtue and is essentially a compilation of Bible passages and relevant expressions of the Fathers. It was written between 860 and $877 .{ }^{18}$ However, as pointed out by Schrörs, most of the content is drawn from Gregory the Great's Moralia in Iob. ${ }^{19}$ Hincmar indicates this himself (pp. 102f.) - although, contrary to his usual habit of quoting, there is a lack of references and direct quotations in the De cavendis vitiis et virtutibus ad Carolum Calvum Regem; the other patristic sources remain largely unspecified. ${ }^{20}$ Schrörs notes that Hincmar appreciated patristic anthologies ${ }^{21}$ - and more of them existed by Hincmar's time. Schrörs refers to Epist. $76,{ }^{22}$ written by Lupus Servatus to Hincmar, which reveals that Hincmar once asked Lupus for a commentary on the Pauline epistles compiled by Bede from Augustine's writings. ${ }^{23}$ Already Schrörs hints at the lack of originality in the De cavendis vitiis et virtutibus ad Carolum Calvum Regem. ${ }^{24}$

In his biography Hincmar, archevêque de Reims, 845-882, under "Appendice II: Dogmatique et Patristique," 25 Devisse provides a table counting Hincmar's direct references to the texts of relevant authors at four different stages of Hincmar's work: before 860, in 860 , between 861 and 870 as well as between 871 and 882 . Devisse does not identify the particular works in which the references to these authors occur. Augustine is one of the authors listed. ${ }^{26}$ The table shows that, overall, Hincmar quotes the De civitate Dei thirteen times in his works: three times before 860 (once in Epist. 48, which are the fragments of a letter sent to Archbishop Amolo of Lyons before March 852, recounting the incidents at Gottschalk of Orbais' conviction and detailing Gottschalk's heresy), ${ }^{27}$ once in 860 (either in the De praedestinatione Dei et libero arbitrio ${ }^{28}$ from early 860 which is extant - or, less likely, in the De divortio Lotharii regis et Theutbergae reginae, ${ }^{29}$ written between March and October 860 ), once between 861 and 870 and eight times between 871 and 882 (all these references can be found in the 
De regis persona et regio ministerio from ca. 873$).{ }^{30}$ The De regis persona et regio ministerio is indisputably the work in which the obligations of the ruler as a moral authority are most clearly defined, and the one in which Hincmar takes the most uncompromising stance towards moral failure on the ruler's part. It is therefore not surprising that this work contains by far the highest number of direct references to the De civitate Dei.

As far as Hincmar's Epistolae are concerned, my enquiry asks how and with what objective Augustine is formally represented in them. Those letters with explicit references to Augustine sent to secular as well as religious authorities are scrutinised, and I illustrate how Hincmar uses Augustine in his arguments alongside other patristic, dogmatic (and legal) sources.

The text by Hincmar that is referred to as the Expositiones ad Carolum Regem is made up of three legal opinions written for the Synod of Pîtres in 868. The first opinion, the so-called Quaterniones, contain all the explicit and implicit references to Augustine that can be found in this work.

Hincmar's text De regis persona et regio ministerio is a 'mirror for princes' written for King Charles the Bald. In it, both explicit and implicit influences of Augustine can be found. It appears that the art of ruling promulgated by Hincmar is imbued with Augustinian elements of political ethics. More precisely, these elements used by Hincmar belong for the most part to the political doctrine developed by Augustine in the De civitate Dei. This stands in contrast, for instance, to twelfth- and thirteenth-century 'mirrors for princes', which are usually much more influenced by Vegetius. In establishing principles on how to be an exemplary Christian ruler, Hincmar evidently takes a moral approach. Moreover, the De regis persona et regio ministerio is interesting for my research because a dominant theme in Hincmar's works is guidelines on how to lead a Christian life according to certain moral criteria, or on how to govern by adhering to Christian political ethics. The genre of 'mirrors for princes' was meant to instruct Christian rulers. My study is premised on the argument that political ethics were valuable for inculcating a sense of common mission for secular power and thus formed a crucial part of Carolingian political thought. ${ }^{31}$

It remains to be seen what specific moral values Hincmar expected of the Carolingian rulers and how he evaluated the Carolingian rulers' particular association with God. This third part of the research attempts to reveal which Augustinian elements of political ethics and political thought found most resonance with Hincmar.

The first section of the analysis of Hincmar's source material is devoted to locating direct evidence of Augustine alone. It is examined in what ways and for what purpose Augustine is explicitly represented in Hincmar's texts. As a complement to the investigation of Alcuin's Epistolae in the first chapter of Part II, I look at some letters from Hincmar that include various explicit references to Augustine. Hincmar wrote several hundred letters to kings and emperors, popes and bishops. Many of them have not survived in the full text, but only in a summary by Flodoard of Rheims in his Historia ecclesiae Remensis. The approach to the epistles is the following: a sample letter from Hincmar to Charles the Bald 
(Epist. 99) is selected for discussion. Its subject matter, structure and argument are considered in a summary. I show how Hincmar integrates Augustine into his reasoning. Following the study of Epist. 99, other letters whose argument is heavily based on Augustine are treated. I discuss their content and explore the relationship that exists between them with regard to the direct references to Augustine.

A general survey of Hincmar's Epistolae has revealed that Hincmar draws on Augustine mainly in his texts against Gottschalk's doctrine of predestination and in his criticism of the divorce of King Lothar II. The reason for this most probably lies in the relation that exists between the function of paenitentia in ninth-century Carolingian legal proceedings and the existing debate over praedestinatio based on Augustine. What is more, throughout the Epistolae, Prosper of Aquitaine is prominent alongside Augustine and appears as a leading exponent of Augustine's teachings - especially in Hincmar's arguments on predestination. Furthermore, particularly in the letters concerned with Gottschalk's heresy and free will, Hincmar tends to quote pseudo-Augustinian next to Augustine (by using the pseudo-Augustinian Hypomnesticon).

\section{Hincmar's Epistle 99}

Epist. 99, written to King Charles the Bald, is a dedicatory letter for Hincmar's first extensive work ${ }^{32}$ against Gottschalk on predestination. ${ }^{33}$ This was written between September 856 and the beginning of 857 but does not survive. According to Hincmar himself, it consisted of three volumes. ${ }^{34}$ The only surviving parts are the contents of the dedicatory letter Epist. $99 .{ }^{35}$ A later version survives from late 859 and early 860 , the so-called De praedestinatione Dei et libero arbitrio. It is a detailed and lengthy report to King Charles the Bald on Gottschalk's doctrine of predestination and the Synod of Langres in 859, which is rejected by Hincmar. Hincmar himself refers to this work as a compendium of his first work. ${ }^{36}$ In Epist. 99, Prosper features once together with Augustine. ${ }^{37}$ Apart from them and the Holy Scriptures, other influential authors such as Bishop Remigius of Rheims, St. Paul, Gelasius, Bede, Gregory the Great, Archbishop Theodore, Paulinus II of Aquileia, Alcuin of York and Charlemagne are mentioned. ${ }^{38}$

Epist. 99 has been singled out and is dissected as a sample letter on the following grounds; the writing contains a number of references to Augustine along with other, later religious (and secular) authorities. As a result, it can shed light not only on the significance and function of Augustine within the argument but also on Hincmar's evaluation of later authorities in relation to Augustine - particularly as far as their method of treating and interpreting other writers' texts is concerned.

After the death of Augustine and his adherents Prosper and Hilary (who had supported Augustine in the struggle against the doctrine of Pelagius), the Fifth Council of Orange (529) endorsed most of Augustine's doctrine of predestination and free will and defended a strict Augustinianism against Semi-Pelagianism. ${ }^{39}$ From the late 830s onward in the Carolingian period, the Saxon theologian Gottschalk started to preach "double predestination," 40 which he based on the theology of Augustine. ${ }^{41}$ His strong position launched a public controversy over 
predestination and free will among ninth-century Carolingian theologians. ${ }^{42}$ Two opposing parties were involved in this controversy: "double predestination" was supported in a more moderate form by the so-called Augustinian party of Remigius (Archbishop of Lyon), ${ }^{43}$ Lupus Servatus (Abbot of Ferrières), ${ }^{44}$ Ratramnus (monk of Corbie) $)^{45}$ and Prudentius (Bishop of Troyes) ${ }^{46}$. Their position was sanctioned by the Synod of Valence in $855^{47}$ and the Synod of Langres in $859 .{ }^{48}$ The socalled Semi-Augustinian party consisted of Hincmar (Archbishop of Rheims), ${ }^{49}$ Rabanus Maurus (Archbishop of Mainz) ${ }^{50}$ and Pardulus (Bishop of Laon) ${ }^{51}$ and promoted a conditional predestination - in simple terms, a predestination to salvation only (by allowing free will). Their view was confirmed by the Synod of Quierzy in $853^{52}$ and partly by the Synod of Savonnières in $859 .{ }^{53} \mathrm{~A}$ third opinion was held by John Scotus Erigena; this was aimed against Gottschalk but at the same time was not in line with the orthodox view..$^{54}$

It has to be stressed that both main parties in the public debate over predestination recognised Augustine as the highest authority in the Latin 'church'. They jointly accepted Augustine's doctrine of salvation, i.e. the doctrine of a universal fall in Adam and a limited redemption through Christ. They also agreed that some humans are saved by receiving the gift of God's grace, while others are condemned by their own sins, and that the hope of salvation is limited to human life (which means that a man's earthly exertions alone may have an influence on God's last judgment). However, the Augustinian party supported "double predestination," i.e. predestination to both salvation and condemnation; the SemiAugustinian party taught single predestination (to salvation) and claimed that God's grace is offered to all humans due to the universal passion and benevolence of God. ${ }^{55}$ It emerges that the Augustinian system is more abstract, while the Semi-Augustinian scheme is more practical and more amenable to the principles and mission of the earthly Christian 'church'. Hincmar declared himself to be an Augustinian. Yet, although he generally adhered to the Augustinian propositions, he failed to see to some extent their logical consequences. For instance, Perels' edition of Hincmar's Epistola ${ }^{56}$ reveals particularly well that in the letters dealing with predestination and free will, Hincmar quoted generously and without restriction from the pseudo-Augustinian Hypomnesticon. As a result, Hincmar strengthened the more moderate view of predestination to salvation only, which shows greater flexibility with regard to free will but is not entirely faithful to Augustine's thought.

There are five Carolingian 'church' councils that were concerned with predestination and that produced capitula on this debate; the Synod of Quierzy (853) brought forth four capitula against Gottschalk (the third one is taken from the writings of Prosper) ${ }^{57}$ Hincmar's point of view was endorsed before the emperor (Charles the Bald). Gottschalk was declared a heretic, deposed as a priest and imprisoned. At the Synod of Valence (855), Emperor Lothar I summoned fourteen bishops of the 'church' provinces of Lyon, Vienne and Arles. Hincmar was accused of contradicting the Synods of Africa and Orange. The four capitula of the Synod of Quierzy (853) were attacked, and the main positions as understood by Archbishop Remigius of Lyon were confirmed. ${ }^{58}$ These objections made at the 
Synod of Valence (855) are criticised in Hincmar's two comprehensive works on predestination and free will (of which only the second is extant). ${ }^{59}$ The Synod of Langres (859) was held under the authority of Charles the Bald, who requested that bishops from the provinces of Lyon, Vienne and Arles meet at Langres in order to amend the capitula on predestination made at the Synod of Valence (855). ${ }^{60}$ The bishops conducted revisions, the censure of the four capitula was lifted and a compromise was arranged. The Synod of Savonnières (859) near Toul was attended by bishops from twelve provinces. Archbishop Remigius of Lyon again made an effort to have his position on predestination, as presented at the Synod of Valence (855) and corrected at the Synod of Langres (859), reaffirmed by the council. ${ }^{61}$ But the decision was deferred until October 860 , when an agreement was made at the Synod of Toucy (near Toul). The synod was chaired by Emperor Charles the Bald, King Lothar II and Charles of Provence. ${ }^{62}$ An assembly of bishops of fourteen ecclesiastical provinces succeeded in terminating the dispute on predestination between Hincmar (the adversary of Gottschalk) and the 'church' of Lyon. It rejected the doctrine of predestination to condemnation and declared its support for the idea of God's universal benevolence in Prosper's (and Augustine's) terms. Hincmar was the person in charge and composed the synodical letter. Even though Hincmar had the final say in these decisions on the doctrine of predestination and free will, his stance was not ecumenically sanctioned. Pope Nicholas I, having sympathy with Gottschalk and being dissatisfied with Hincmar on hierarchical grounds, is said to have upheld the Augustinian capitula of the Synod of Valence (855) and the Synod of Langres (859). On this basis, a revival of strict Augustinianism was able to take place in the sixteenth century.

The main content of Epist. 99 is concerned with the fact that in the capitula of the Synod of Valence (855), Hincmar finds himself attacked and humiliated in a disrespectful and unbrotherly manner. It is important to note, however, that Hincmar is not mentioned by name. Nevertheless, Hincmar observes that in these capitula, the four capitula of the Synod of Quierzy (853) against Gottschalk (i.e. the decisions he himself proposed) are ridiculed and dismissed. The fourteen bishops of the 'church' provinces of Lyon, Vienne and Arles, summoned by Emperor Lothar I at the Synod of Valence (855), did not want to insert the four capitula of the Synod of Quierzy (853) into their writings. Instead, Hincmar maintains, the meaning of these capitula has been distorted in a manner harmful to his reputation, since Hincmar is criticised for arguing against the synods of Africa and Orange. The opening of Epist. 99 is as follows:

Hincmar, bishop of the people of Rheims - although the name has not been deserved - to the glorious master King Charles together with my fellow lords and brothers, the venerable bishops, devoted in prayers for both your salvation and prosperity.

We say thanks to God, who inflames your heart with love of Him and has ignited in it the knowledge of truth and the science and love of orthodox faith; who has also given you prudence and understanding in the divinely inspired writings; and who, by the study and practice of these writings (as much as 
your responsibilities to the 'state' permit you), raises with daily increase the endeavours of your devotion to the usefulness of His holy 'church'.

In other respects, we repeat the synodal capitula ${ }^{63}$ of our very venerable fellow bishops, naturally of three provinces, ${ }^{64}$ exactly as it is contained in this same place and as will be found written further below: these capitula have been delivered to you, and you have been given them to read and discuss, in concurrence with the custom of preceding kings, for the study of the truth to be understood, to our humility in accordance with the Scripture that teaches: 'Ask the priests about my law', since we read that there is also a law of the faith. In these, although our names have been omitted, we nevertheless find ourselves by clear designation, reproved as non-Catholics and scorned without respect for brotherhood. Also we find the capitula ${ }^{65}$ - which we extract for you from the sentiment and words of the Catholic Fathers for the purpose of recognition and below as a necessity to be made clear - rejected and abhorred, as if useless, or even harmful. These capitula, as they have been extracted from us, they did not want to insert into their writings, nor were they read by those, in whose hands their capitula ended up; but some of the things, which were contained in the capitula gathered by us, they have duped into an other sense and other words, that they could show that these have to be abhorred, other things, however, they suppressed and have thought about it in a way as if we believed against the ideas of the holy Fathers in the synod of Africa and Orange. ${ }^{66}$

After these initial comments, Hincmar complains that, apparently, the bishops who assembled at Valence included content from certain XIX capitula (either taken directly from John Scotus' De divina praedestinatione or from an extract composed by Archbishop Wenilo of Sens ${ }^{67}$ ) into their writings, which they presented as originating from Hincmar. Hincmar says that Augustine, during his lifetime, had also been the victim of adversaries who had twisted his words and assigned a wrong meaning to them, in order to harm his reputation. Those opponents, however, Augustine could repel with his orthodox reasoning. Then, after Augustine's death, there were those who were jealous of the high esteem Augustine had gained among theologians and who tried to use Augustine's writings in order to damage his name and enhance their own image. One of the few rightful exponents and apologists of Augustine was Prosper, who was able to prevent Augustine's rivals and prove Augustine right with the help of Pope Celestine at Rome. Besides the original Augustine, Prosper is a source Hincmar recommends relying on. By arguing in this manner, Hincmar indicates that it is vital for theologians to read and quote Augustine's works in the original and not to refer to Augustine indirectly by using the words of successors who are discussing the doctrine of Augustine. Hincmar writes:

They have also inserted into these same writings [things] from certain XIX capitula as though they should be ascribed to us, though we have neither heard nor seen anything about them - and inserted them before the venerable 
Bishop Ebbo of Grenoble has delivered them to you, as if transmitted by your brother Lothar I of good memory, at the palace of Verberie. The author of these capitula we have neither found annotated here nor been able to find, though we have researched it a lot. Therefore we think, because they have been compiled by the envy of someone in order to dishonour the reputation of a certain person (as we often read), that should recount a few of the many things which the venerable Bishop Ibas ${ }^{68}$ has denied to be his in the synod, just as the epistle of capitula has now come to light - and as certain rivals ${ }^{69}$ had already done to the words of the blessed Augustine during his lifetime, which he denounced and catholically repelled, as much as came to his knowledge. Also after his death certain envious people have made an effort to collect a capitulum of his own writings - even of those which are presently dealt with - in order that they could have superior power to weaken his orthodox and most useful doctrine out of envy for his person, and to turn away devoted readers from the reading and estimation of him, as well as necessary belief in him. St. Prosper has shown in a Catholic and prudent style from the delegation to the holy Roman see [occupied] by Pope Celestine ${ }^{70}$ that these fictions of rivals are evidently false and carelessly presented, and has most clearly demonstrated that the doctrine of the man who is celebrated - and should be celebrated - is orthodox. ${ }^{71}$

Hincmar is outraged by the bad practice of his fellow bishops. He alleges that the way in which they indicated the faults of the capitula of the Synod of Quierzy (853) was disapproving. He draws attention to the dominical rule on how to voice criticism to a colleague. Hincmar would have appreciated a constructive conversation with his fellow bishops before being judged. Thereupon, Hincmar uses Augustine as a role model of a fair-minded critic. He contends that Augustine always tried to be as impartial in judgment as possible. For, whenever he found anything that was well said in a text of his opponent, he acknowledged it and never attempted to weaken the other's work by trying to alter the meaning of the content. Hincmar raises the question:

How can it even happen that these capitula, which have been delivered or transmitted to you under the name of our colleague by persons other than themselves, have somehow not been recorded as an offence against us, but have been made at the instigation of the devil, alongside other evils - which now become frequent in this world - in order to cast discord among the priests of the Lord: the devil who both vehemently dreads and envies the love among us, when he sees that it is retained by us worldly men on earth, which this angelic spirit, refusing to retain, has let go to heaven. ${ }^{72}$ For how could it happen that our brothers condemn us thus in anger, with a view of annihilation, who always have the dominical rule, on how each one must admonish his colleague, before their eyes and in daily use? For they understand what is written: 'Before you ask, do not find fault with anyone and, when you have asked, reprove justly.' For St. Augustine received the writings of his heretics 
and denouncers most benignly if he found anything in them that was well said, and he made an effort to interpret several in their right sense, but he did not attempt to divert any from their right sense to a wrong sense. ${ }^{73}$

Hincmar rejects the capitula of the Synod of Valence (855) also for the reason that Bishop Ebbo of Grenoble ${ }^{74}$ is conspicuously mentioned together with the archbishops, while the names of his fellow priests are excluded in the text. Moreover, Hincmar points out that, among the named archbishops, the role of Augustine is not sufficiently appreciated in the capitula. He maintains that Augustine's contribution in the African councils surpasses that of any past or present archbishop. Again, Augustine features as a role model of good practice; Hincmar claims that, although Augustine outperformed everyone else in hard work, intellect and caution during his lifetime, he would neither have placed himself nor would have allowed to be placed before any other theologian. On the contrary, asserts Hincmar, Augustine tended to place himself below everyone else and would never have allowed any of his fellow bishops' names to be left out. On the whole, Hincmar demands that Augustine should be referred to more explicitly as the highest authority in the Latin 'church' and at the same time be taken as a role model of good practice in councils by the bishops who were present at the Synod of Valence (855). Hincmar reasons:

And on that account we disbelieve that these capitula $^{75}$ have been made by those, because, while the names of the other fellow priests have been omitted, the name of Ebbo ${ }^{76}$ alone is in the same place boastfully, as it seems to some, expressed together with the archbishops. And that he himself has collaborated on this in the highest degree, as it would make sense from the region, that among the archbishops he has also been greater and more learned than the others in his way of thinking, this, for instance, we find not at all about St. Augustine, who has emerged as greater in knowledge and hard work as well as vigilance in the African councils. For not only has St. Augustine himself refrained from placing himself or allowing himself to be placed before the other fellow bishops, seeking personal glory, but has indeed placed himself below the others, even though he himself has worked more than the others, just as anyone will be able to find in the epistles written to Pope St. Innocent and to the other protectors of the apostolic see, if they wish to read it there. And we do not read similarly about any of the bishops in any councils, unless perhaps the apostolic writings have decided for an evident reason to designate anyone of the fellow bishops by name to this affair together with his archbishop, such as we read about the bishop of Autun in the letters of the blessed Gregory. By how much more this religious and careful man would not have wanted to elevate himself of this sort or would have allowed to be placed before by his fellow other bishops who were snubbed and omitted! It has come to this point, since our brothers and fellow priests did not have to go through the monitory saying of Solomon with a deaf ear, when they have accepted anything improper in secret from us, either by hearing or by writing, 
in order that they, driven by whatever activity of ours, make that official in public in extreme haste, of which we are not conscious, at disputes and official speeches, for he says: 'The things that your eyes have seen, do not carry [them] into a dispute quickly, for afterwards you cannot make amends, when you have dishonoured your friend. ${ }^{77}$

The end of this dedicatory letter is worthy of attention. In the main part of Epist. 99, Hincmar has shown that, due to his greatness in all respects, Augustine should be read and quoted in the original and his merits need to be acknowledged explicitly in the records of the 'church' councils. Apart from Augustine, the only reputable figures mentioned up to this point (besides Bishop Remigius of Rheims ${ }^{78}$ ) have been Prosper, together with Pope Celestine. Hincmar regards Prosper's opinion as orthodox since it corresponds to his own understanding of Augustine's doctrine. At the end of Epist. 99, however, Hincmar calls into play a range of religious and secular authorities, whom he uses as key witnesses. They are included in order to testify to the orthodoxy of Hincmar's (and Prosper's) interpretation of Augustine. The mentioned authorities are: Gelasius, Bede, Gregory the Great, Archbishop Theodore, Paulinus II of Aquileia, Alcuin of York and, last but not least, Emperor Charlemagne himself. All these are presented as aligning themselves alongside Augustine, Prosper and Hincmar against the bishops who were involved in the Synod of Valence (855). Hincmar declares:

We embrace with equal reverence also the sentences of those who, after the canon itself had been composed by the blessed Gelasius, flourished in the 'church' with divine honour, in thought and Catholic doctrine, as well as in the sanctity of conversation; and who have written or taught nothing dissonant and nothing contrary about the trustworthy since Catholic doctrine of the Orthodox Fathers, who are themselves annotated in the same canon: and likewise those of the venerable presbyter Bede, imbued with the Catholic faith by the disciples of Pope St. Gregory and by Archbishop St. Theodore, ${ }^{79}$ trained in both languages - Greek and Latin - and sent by the Holy Roman 'church' to the Anglos for instruction in the manner of the blessed Gregory's disciples; and also no less those of the learned and of venerable memory Patriarch Paulinus, of the parochiality of Aquileia; and those of the religious and learned man Alcuin. The apostolic Roman see has not only benignly accepted their faith and doctrine, but has also elevated it with great praise, just as we find in the writings of the holy see itself, which our 'churches' have accepted from the same mother of 'churches' at the time of Emperor Charles $^{80}$ of divine memory, when the synod ${ }^{81}$ about the known infidelity of Felix $^{82}$ has been held and transmitted to the Roman 'church' just as to the summit of 'churches'. But also the one who reads their writings understands to what degree they should be praised and received. ${ }^{83}$

It has been found that although the doctrine of Augustine is at the heart of the debate on Gottschalk's interpretation of predestination and free will, the purpose 


\section{Hincmar of Rheims}

of Hincmar's direct references to Augustine in Epist. 99 is rather practical. The subject matter of the dedicatory letter is the behaviour of the bishops assembled at the Synod of Valence (855) in response to the four capitula, and the decisions taken at the Synod of Quierzy (853) under the direction of Hincmar and endorsed before Charles the Bald. Hincmar is under the impression that the bishops present at Valence tried to harm his reputation as a theologian for their own gain. He feels that his contributions to the judgment made at Quierzy have partly been ignored, partly misinterpreted, and criticised. Furthermore, he insists that some of the content assigned to him does not originate from him. By using Augustine, Hincmar explains that even though Augustine's doctrine had been exposed to criticism throughout Augustine's life and has since been repeatedly questioned by jealous opponents, Augustine had always been a fair-minded critic and a role model of good practice. It is clearly the case that in Epist. 99 Hincmar draws attention to the importance of reading and quoting Augustine in the original and not through intermediaries (who may flaw his work) and of acknowledging Augustine as the highest patristic authority. However, for the most part, Hincmar's argument in the letter is that it is virtually impossible that those bishops who criticised his own view of predestination and free will at the Synod of Valence (855) actually understand Augustine and his doctrine correctly, seeing as their bad practices in giving a judgment are entirely opposed to Augustine's method of treating and judging texts of authors he did not agree with. Rather, Hincmar's own practices, views and standards are those which resemble Augustine's most. Therefore, it is his opinion that must be declared valid.

\section{Hincmar's Epistles 179, 28, 37 and 48}

Epist. 179 is directed to Louis the German and explains to the king the contents of Psalm 103, 17. It is composed after the 19th of February 865. Epist. 179 is mentioned here as a representative example of those letters that are concerned with subject matters other than predestination, free will and the divorce of King Lothar II. Typically, Augustine and Prosper are mentioned together ${ }^{84}$ Various authorities such as Jerome, Cassiodorus, Gregory the Great (and St. Paul) are prominent. ${ }^{85}$ In this epistle, the direct references to Augustine have no particular significance alongside those of other Church Fathers.

There are three other distinctive letters that are directly concerned with Gottschalk, his conviction and doctrine of predestination: Epist. 28, Epist. 37 and Epist. 48. They are noteworthy because they express, firstly, the nature of the dispute on predestination; secondly, the way in which Hincmar reproaches Gottschalk for his view of predestination; thirdly, which parts of Augustine and pseudo-Augustine Hincmar quotes most often and, lastly, what function the direct reference to Augustine's De civitate Dei in Epist. 48 performs. Moreover, while in Epist. 28 and Epist. 37 Augustine is the only Church Father named in person as the protector of the apostolic faith ${ }^{86}$ and leader in the struggle against heresies ${ }^{87}$ (whereas the remaining Fathers are mentioned only as a collective), Epist. 28 and Epist. 48 confirm Prosper and Hilary as the main apologists of Augustine used by Hincmar. ${ }^{88}$ 
Epist. 28 is a brief missive directed at Gottschalk himself and concerns itself with his view of predestination. It was written in 849 and displays Hincmar's criticism of Gottschalk's doctrine. Hincmar claims that the monk became a heretic mainly because he failed to understand what Prosper had written and demonstrated on the basis of Augustine's teaching. Hincmar writes:

To the monk Gottschalk, who has slipped into heresy because of some authors' sentences, which he has neither understood nor interpreted well especially of Prosper, whose meaning he mainly interprets through sentences of the blessed Augustine. Declaring other suitable doctors as witnesses of the apostolic faith, he urges that their doctrine has to be followed by everyone; and he shows by manifest evidence that God foreknows both the good and the bad, but He only foreknows the bad, while the good He both foreknows and predestines. Thus, prescience can also exist without predestination: predestination, however, cannot exist without prescience; and since He foreknew as well as predestined the good to enter the Kingdom, but only foreknew the bad, He did not predestine the bad, nor did He compel that they perish by his prescience. ${ }^{89}$

Epist. 37 consists of the foreword, conclusion and notes to Hincmar's first writing against Gottschalk on predestination. The writing Ad reclusos et simplices in Remensi parrochia contra Gothescalcum is a circular letter to the members of his diocese concerning Gottschalk's stance on predestination. It was written between 849 and 850, and Augustine is used explicitly at the end of the foreword. The context is thus: Hincmar says that those who did not understand correctly have distorted the meaning and interpretation of what Augustine and the other Church Fathers had said in their fight against heresies to their own destruction. Hence, Hincmar recommends that the simplices in his diocese adhere to this brief, summarised exposition. Hincmar states further that the unlearned spoil what has been said correctly, which is confirmed by the statement about the writings of St. Paul contained in the Second Epistle of Peter.$^{90}$ In his writings against Gottschalk's heretical doctrine, Hincmar repeatedly calls attention to Peter's Second Epistle, because it emphasises the importance of the correct interpretation of the Holy Scriptures. In Hincmar's reference to the Church Fathers, Augustine is the only Father named in person. In other words, in Epist. 37, concerned with Gottschalk's doctrine of predestination, Augustine appears as the spearhead of the struggle against heresy. The end of the foreword addressed to the simplices is an attempt to justify why the Word of God should be communicated in an appropriate language to the uneducated and simple people. It is worded as follows:

For this collection is not considered necessary by those who are learned and erudite, and a vulgar discourse of this sort seems unworthy [to these men], who even in their understanding abound with gratefulness to God and who have learned the Holy Scriptures and the Catholic expositions of the holy Fathers. But you, with whom divine wisdom speaks conformably to your 
holy simplicity, as it is written: 'His conversation is with the simple people', nevertheless hold onto this brief chapter and Catholic collection, since you do not have an abundance of books and have not studied or read these oratorical tergiversations. Just as when the blessed Paul poses questions as a great orator in his epistles and solves them for us, and as the blessed Augustine and the remaining doctors have dialectically said, fighting against the heretics: those who understand less when they speak - by investigating, or by extending, or by solving - 'distort' these things which have been said correctly, and do so 'to their own destruction' (as the blessed Apostle Peter says, speaking about the epistles of St. Paul). From there, much could be collected from the sayings of the many Fathers. But since they all hear and say it according to the Apostle, and it has all been collected for you succinctly under the name of the few - some of it by sense, some of it by the words expressed by the very same - take it as sufficient. ${ }^{91}$

Epist. 48, the fragments of a letter sent to Archbishop Amolo of Lyons, relates the incidents at Gottschalk's conviction. This epistle was drafted before March 852. Besides Augustine, Hincmar uses the Holy Scriptures and quotes from Matthew, Paul, Peter and John. Prosper and Hilary feature as debaters and supporters of Augustine in his argument against Pelagius and his main follower Caelestius. ${ }^{92}$ The letter ends with the Holy Scriptures and excerpts from the Book of Psalms. ${ }^{93}$

Epist. 37 and Epist. 48 both display the public debate over predestination and explain Gottschalk's heresy by making explicit reference to Augustine (and pseudo-Augustine) in a discussion of the notions of praescientia, praedestinatio, praeparatio and liber arbiter. The main theme of Epist. 37 and Epist. 48 is that praescientia ("prescience") refers to God's foreknowing of the good and the bad, while praedestinatio ("predestination") refers to God's foreordaining of only the good. Praedestinatio ("predestination") may be deemed the equivalent of a praeparatio ("preparation") for grace and (eternal) life. Those who teach "double predestination" are on the wrong track; praedestinatio ("predestination") is not intended to speak of divine foreordaining of damnation. Some excerpts from Epist. 37 and Epist. 48 show which parts of Augustine and pseudo-Augustine Hincmar quotes repeatedly.

The conclusion to Epist. 37 (the first writing against Gottschalk) is interspersed with direct references to Augustine. Hincmar explains:

For 'predestination', as the blessed Augustine says, 'is designated by the sending in advance and anticipating or preordaining of anything future. And thus God - for whom prescience has always been and is no accident but rather His very essence - foreknows whatever is before and predestines it: and $\mathrm{He}$ predestines it for the reason that He foreknows of what sort the future is. The bad, namely, He only foreknows - the good, however, He both foreknows and predestines.' And elsewhere Augustine again says: 'Predestination is preparation for grace, and grace itself is a gift of life, that is the result of predestination.' And man, as we have mentioned much earlier, has neither 
been created nor predestined by God, in order to be sent into the eternal fire, nor has the eternal fire been created because of man, but because of the devil, just as the Lord says in the Gospel: 'It has been prepared for the devil and his angels'. ${ }^{94}$

Later on, Hincmar restates:

Prescience is foreknowing, what is known before that would happen or how would happen what is known; 'predestination', however, 'is', as St. Augustine says, preordination or 'preparation for grace', that is, as the Apostle says: God has predestined the elect to glory and has prepared them - that is preordained [them] - in faith, in good deeds, so that they would arrive at the grace of reward through those deeds, just as it is written: 'These God has prepared' - obviously the good deeds - 'in order that we may walk among them'. This is predestination. After the predestination, however, and preordination or preparation of God (which is according to the plan of His good will) nothing else follows, except for 'the result of predestination': that is 'grace', which is 'itself a gift' of life. ${ }^{95}$

A part of Epist. 37 is repeated in the following passage from Epist. 48:

But, just as foreknown, He has predestined some from the burden of $\sin$ - that is He has prepared [them] by grace - for the life and Kingdom; and those He has predestined to the life and eternal Kingdom - that is has prepared [them] by grace - to which the Gospel attests when it says: 'Come, blessed ones' - that is those freed ones by grace from the first condemnation, and those elected and predestined -, 'take possession of the Kingdom that has been prepared for you', that is that which has been predestined for you, 'from the beginning of the world'. Some, however, He has not predestined to death nor to the fire, as no doubt they were foreknown, but has left them justly in the burden of sin and perdition, from which He has freed those by His 'predestination', that is 'preparation for grace', by a judgment which is hidden but by no means unjust. For, just as the blessed Augustine sets forth, 'predestination is preparation for grace: grace, however, is a gift of life' - that is 'the result of predestination itself'. And the blessed Prosper, commentator in this matter of St. Augustine, agrees with the other orthodox Fathers when he says: 'Predestination' is nothing else but what 'relates to the gift of grace or to the retribution of justice' ${ }^{96}$

What Epist. 48 further shows is that Hincmar is unable to deny that, in principle, to some extent the unbeliever falls prey to damnation; ${ }^{97}$ and it is here where the only explicit reference to Augustine's De civitate Dei appears (together with Augustine's Enchiridion), which can be found in these letters on predestination. ${ }^{98}$ In other words, Hincmar cannot make use of the De civitate Dei in order to support his main argument against "double predestination." Nevertheless, by using 
the pseudo-Augustinian Hypomnesticon, Hincmar eventually succeeds in arguing that only malicious members of the 'church' are teaching "double predestination." 99 The text is as follows:

I also write down some examples for your wisdom, just as they come to mind at this moment, which those men out of the very same foolishness put forward for their defence, proffering them because of faulty understanding. They bring forth from the Apostle that 'the vessels of wrath have been prepared' or finished 'for destruction', saying that the vessels are predestined for destruction and cannot be changed. But others understand it differently, particularly when the same Apostle says about the same vessels: 'If anyone has purged himself from these' - obviously for whom the vessel had been of shame - 'he will be a vessel unto honour'. They set forth that 'Whoever does not believe is already judged', that is, is already condemned by the predestination of God. And Augustine says in the book about the Christian contest: 'Whoever does not believe is already judged', that is, 'is already condemned - certainly by the prescience of God, who has learned what threatens those who do not believe'. They set forth: 'The Lord has hardened the heart of Pharaoh'. 'God has given them over to a depraved mind', He will send against them the spirit of error. 'To be sure, you God will lead them away into a pit of extinction'. 'Whoever passes over from justice to injustice, God has prepared him for the javelin'.

But these ill-disposed people, not understanding what they are saying or what they give assurance of, confuse prescience with predestination. And just as they understand poorly the authentic texts, so too they understand even more poorly the words of St. Augustine in certain places, as when he says in the Enchiridion - and in the books of the De civitate Dei and elsewhere - that they are also predestined for destruction and the people born for wrath. From there, after he had written under the prosecution of many about free will and rebuke and grace and man's perfection in justice and the predestination of the Saints to Prosper and Hilary - where he said nothing about the predestination of the rejected, but instead about the predestination of the Saints - he has written the book Hypomnesticon ${ }^{100}$ against Caelestius and Pelagius about the five questions; and this sixth one he has added about predestination in the place of correction. There he excuses himself that he has not said or wants to be understood in the sense that they are predestined for destruction, but that a penalty is predestined for those who persist in injustice and impiety. He makes mention of these questions and acquittals in the book, which he has written against the Manichaeans about the Genesis. ${ }^{101}$

\section{Hincmar's Epistles 134 and 108}

Epist. $134^{102}$ consists of Hincmar's foreword to his De divortio Lotharii regis et Theutbergae reginae. The work itself is written in 860 and is a detailed report on the legal dissolution of the marriage between King Lothar II and Theutberga. ${ }^{103}$ 
Hincmar answers to the questions of unspecified religious and secular figures, and the text is divided accordingly into twenty-three responsiones. The work also contains the acts of the Synods of Aachen in January and February 860. Epist.134, i.e. the foreword, ends with Augustine and Gregory the Great. Gregory the Great (together with his Regula pastoralis) prevails. In addition, the Holy Scriptures (which are also dominant) and other authorities, such as Innocent, Celestine, St. Peter, Bede, Jerome, St. Paul and Cyprian, appear throughout the foreword.

In the foreword, Hincmar voices his thoughts on the divorce of King Lothar II; it is not Hincmar's opinion that the divorce should be categorically prohibited (nor would he have the power to influence the outcome of the cause to such an extent). ${ }^{104}$ But Hincmar finds that an approval of Lothar's conduct by the 'church' is certainly not appropriate. ${ }^{105}$ In the De divortio Lotharii regis et Theutbergae reginae, Lothar's actions are officially criticised by Hincmar. ${ }^{106}$ While Lothar's party insists that the absolute power of law and judgment should lie with the ruler, ${ }^{107}$ Hincmar argues that the secular and religious powers should both take part in reaching a sound verdict, albeit separately (in accordance with the Frankish law). ${ }^{108}$ The nature of the 'church's' involvement, however, is not discussed in greater detail. ${ }^{109}$ But - and here Hincmar uses Augustine in Epist. 134 - the religious power is dominant. Moral failure on the part of the ruler as far as the Christian code of conduct is concerned implies that the 'church' intervenes as the superior power. ${ }^{110}$ Hincmar contends that also the secular law originates from God. ${ }^{111}$ He affirms: "[...] it is necessary for both the ecclesiastical and the civil court to thus give a decision concerning whatever legal matter and person under the eyes of the supernal judge [...]."112 Furthermore, Hincmar gives examples by using the allegories of David and Saul, who were corrected by the prophets. ${ }^{113} \mathrm{He}$ then mentions the case of Louis the Pious. ${ }^{114}$ Hincmar only supports the civil law because he sees in the decisions taken at the Synod of Aachen in February 860 a violation of said law (the bishops involved had apparently applied canon law). According to Hincmar, the proceedings - which were opened under application of the court law - should have been concluded accordingly. The opinion of the 'church' should have been consulted only afterwards - even though in the end it would not carry less weight. ${ }^{115}$

In the foreword to the De divortio Lotharii regis et Theutbergae reginae, Augustine only features at the very end, together with Gregory the Great. Strikingly, Hincmar approaches the affair entirely from the perspective of the 'church' and the clerics who assume the role of representatives of God. In the last lines of the foreword, the function of the clergy (or, more precisely, the bishops) in the proceedings is summarised clearly and concisely:

[...] St. Augustine says in book four Contra Iulianum: Certainly, if we allowed those over whom we have power to commit crimes before our eyes, we would become partakers in their guilt.

But how many innumerable [crimes] does He allow to happen before our eyes, which He would under no condition allow, if He did not want it in any way? 
And $\mathrm{He}$ is nevertheless just and righteous, since He gives room after patience for penitence, and does not wish that anyone perishes. St. Gregory demonstrates why this happens by giving evidence from the Scripture: Highest, in fact, is the patient forgiver, since He both endures our evils and forgives.

For He bears them all day when they are converted, but the non-converted He condemns more sternly. ${ }^{116}$

In the quoted passage from Augustine's work against Bishop Julian of Eclanum, Augustine uses the first person plural to refer to the collective of bishops who are currently in office. He says that, ideally, the bishops may not allow any acts of misconduct on the part of subordinates, as this would violate their own integrity. But then Augustine considers that if God did not want any transgressions to happen, He would not allow them to happen. The transgressions do not affect God's integrity. He does not want anyone to perish and can accept the repentance of the guilty thanks to His patience. Then, explaining why God's integrity is maintained, Hincmar quotes Gregory the Great, who declares that the most virtuous ones are those who are patient and who forgive. The quotation further expresses that God is considerably more tolerant of converted sinners than of non-converted sinners. Augustine acts as a referee in the discussion of the bishops' (or, more generally, the clergy's) role in the case; it is the bishop's or cleric's individual responsibility to prevent potential misconduct of the subordinate. ${ }^{117}$ However, it is not possible for the cleric to prevent all crimes, since this would not be according to the will of God. Therefore, it is also the cleric's duty not to approve of the subordinate's transgressions, but to bear them. Being patient like God, the cleric remains just and righteous when he accepts the sinner's contrition and repentance. This means that Hincmar's own integrity is maintained if he allows the annulment of Lothar's marriage. The condition is that Lothar repents of his action, which is an entirely spiritual, not legal, process. Its significance for the legal proceedings, as proposed by Hincmar in this writing, is therefore remarkable. One may speak of a "secularisation of sin."118

There is another aspect of the discussion of the clergy's function in the case, which has so far been ignored and needs to be stressed. It concerns the manner in which the quotation from Augustine's Contra Iulianum is used. The quoted passage begins with the statement that, in principle, the bishops must not permit any immorality of subordinates, as this would make them complicit. In the context of the dispute over the lawfulness of the divorce of King Lothar II, the statement intimates that, according to Hincmar, King Lothar II as a secular leader is subordinate to the power of the bishops and the bishops are accountable for his misconduct. ${ }^{119}$ Strikingly, Hincmar here quotes Augustine, not Gelasius, in order to assert the superiority of the spiritual over the secular power. ${ }^{120}$ He claims - inter alia by referring to Augustine - that the spiritual power is superior to the secular power and that also the secular law stems from God.

The reference to Augustine in Epist. 134 invites comparison with Epist. 108, where Gelasius, Augustine and Gregory the Great are used in an evaluation of 
the relationship between the secular and spiritual powers. Epist. 108 consists of Hincmar's foreword and the beginning of the conclusion to his work Collectio de ecclesiis et capellis, directed to Charles the Bald. It is written between 857 and the spring of 858. The Collectio de ecclesiis et capellis or Consultatio ad Carolum regem is a collection of canones on the legal status of proprietary 'churches' and the power of bishops in their dioceses, composed as a report for King Charles the Bald.

In the foreword to the Collectio de ecclesiis et capellis, the distribution of power between the 'state' and the 'church' - in particular the authority to administer property - is assessed. Hincmar first introduces the composed collection before coming to the point. He writes:

For that reason, though this may succeed in displeasing some, if perchance there are any who choose to follow without restraint what gladly pleases them rather than what is lawful, I will do what you entreat, knowing that it has been recommended by the Apostle that 'the entire soul', that is the entire man, 'be placed below the higher powers; for there is no power except from God'; and once more he says: 'Be subjected to every human being for the sake of God as much as to a superior king'.

And since your royal sublimity established by God bends the necks of both the heart and the body to the priestly religion, one discerns that it is adequate that also the pontificial authority submits itself to the regal dignity with every obligation of loyalty, just as St. Gelasius shows in the decretal epistle to Emperor Anastasius, saying: 'There are, of course, two [sovereignties], venerable emperor, by which this world is principally governed: the sacred authority of bishops, and the royal power. Of these, the importance of the priests is that much greater, by how much they will also have to account for the kings of men themselves in the divine examination'. Hence, 'as far as the order of public discipline is concerned, understanding that the supreme power has been conferred on you by a supernal arrangement, even the priests of the religion themselves are obedient to your laws, so that the sentences, excluded from secular affairs, do not seem to obviate'. And elsewhere: 'Since Christ, mindful of the human fragility and that it was suited to the salvation of His [people], has thus regulated by sublime dispensation, in the same way has He set apart the offices of each power by particular public functions and separate dignities, wishing that His [people] are saved by medicinal humility, not snatched once more by human pride; so that the Christian emperors stand in need of the bishops for eternal life and then the bishops themselves profit by imperial arrangements for the running of temporal affairs, as long as the spiritual function stands apart from the carnal efforts, and for that reason, serving God, involves itself very little in the secular affairs. In turn the one does not seem to preside over the divine affairs who is involved in the secular affairs, in order that also the moderation of each order is ensured, lest the support on both sides be extolled; and, agreeing with the quality of the functions, the profession is individually adapted.' And St. Augustine says in the Sermo VI. 
Ioannis Evangelii: 'Manifest laws are read, where emperors have instructed those who, separate from the community of the Catholic 'church', use the Christian name for themselves and do not want to worship in peace the very founder of peace and dare to possess nothing in the name of the 'church". 'But what belongs to us', they say, 'and what to the emperor?' 'This is managed by the human law, and nevertheless the Apostle wished that the kings be served, wished that the kings be honoured and said: 'Revere the king'. Do not say: What belongs to me and what to the king? What to you, then, and the possession? By the royal law possessions are possessed'; and in the Sermo VII.: 'For it is a matter of secular law that anyone who lies in any claims may not benefit from what he has brought to pass. For you said what you wanted and to whom you said it; he does not know whether it is true; he sent you away to your adversary to be convicted that, if you are convicted of lying before the judge, you are there deprived of the benefit of the very rescript by which you brought the rescript'. And the sacred canons and decrees of the Roman bishops show that we are bound to pay the kings many times for the honour and status of the 'church', just as anyone who reads it will be able to find. And the blessed Gregory has composed the entire commonitory to the defender John, who is going to Spain, about the imperial laws for the correction and constitution of ecclesiastical sanctions. And the Council of Toledo orders 'that sentences of laws and canons are searched out' for the definition of cases. Therefore, we have to obey the kings serving the cult of piety and the religion and law and comfort. ${ }^{121}$

In the foreword to the Collectio de ecclesiis et capellis, Hincmar quotes Gelasius with regard to the separation of the secular and spiritual powers. Gelasius explains that in religious affairs the religious authorities should be consulted, while in secular affairs the secular authorities should be consulted. ${ }^{122}$ Furthermore, only by order of the emperor does the 'church' acquire the right to own secular property - to the extent that it is necessary for the mission of the 'church'. However, in essence, Gelasius claims the dominance of the spiritual over the secular power. His argument is that the bishops' power is dominant since the bishops take responsibility for the secular leaders' moral conduct. ${ }^{123}$ It is the clerics who will be held accountable for the secular people's actions. Immediately afterwards, Augustine and Gregory the Great are used in support of this reasoning.

This section on direct evidence of Augustine's influence examined in what manner and for what purpose Hincmar refers to Augustine explicitly. A study of the Epistolae has revealed that Hincmar avails himself of Augustine primarily when he writes against Gottschalk's doctrine of predestination, and when he criticises the divorce of King Lothar II. Epist. 179 has conveyed that in contexts where matters other than predestination or the divorce of the king are debated, the direct references to Augustine have no particular significance alongside those to other Church Fathers. Notably, in Hincmar's discussion of predestination, Prosper and Hilary feature alongside Augustine. For instance, Epist. 28 and Epist. 48 confirm Prosper and Hilary as the main apologists of Augustine mentioned by Hincmar. 
Epist. 28, Epist. 37 and Epist. 48. are noteworthy in relation to Gottschalk's heresy. They express, firstly, the nature of the dispute on predestination; secondly, Hincmar's own position in the debate and, lastly, which parts of Augustine and pseudo-Augustine Hincmar quotes in what contexts and for what purpose.

In the analysis of the sample letter Epist. 99, sent to Charles the Bald, it has emerged that the purpose of Hincmar's direct references to Augustine is mainly practical. Of course, Hincmar draws attention to the importance of reading and quoting Augustine in the original and not through intermediaries (who may invalidate his ideas) and of acknowledging Augustine as the leading patristic authority. Likewise, in Epist. 28 and Epist. 37, Augustine appears as the one Father who protects the apostolic faith and leads the struggle against heresies. However, the main argument in Epist. 99 is that the fellow bishops who attacked Hincmar's own view of predestination so insolently at the Synod of Valence (855) cannot possibly have understood Augustine in the right way, seeing as their unmannerliness is opposed to Augustine's method of treating and judging the texts of other authors. Hincmar's own practices, views and standards, however, resemble Augustine's much more. Hence, it is his view of predestination that should prevail.

Epist. 48 contains the only explicit reference to Augustine's De civitate Dei that can be found in these letters on predestination. It shows that, by referring to the original Augustine alone, Hincmar is unable to deny that every unbeliever falls prey to damnation on principle. That is to say, Hincmar cannot make use of the De civitate Dei to support his main point against "double predestination." Hincmar merely succeeds in his argument against "double predestination" by drawing on the pseudo-Augustinian Hypomnesticon.

In Epist. 134, the foreword to Hincmar's De divortio Lotharii regis et Theutbergae reginae, Hincmar refers to Augustine - not Gelasius, as one might have expected -to assert the superiority of the spiritual over the secular power. The passage from Augustine's Contra Iulianum, which Hincmar quotes, opens with the declaration that in principle the bishops must not permit any immorality of subordinates, as this would make them complicit. However, since it is not possible for the cleric to prevent all crimes, it is the cleric's duty to bear the subordinate's transgressions. In the context of the dispute over the lawfulness of the divorce, Hincmar's quotation from Augustine's Contra Iulianum intimates that, according to Hincmar, King Lothar II as a secular leader is subordinate to the power of the bishops and the bishops are thus accountable for his misconduct. By referring to Augustine inter alia, Hincmar claims that the spiritual power is superior to the secular power and that also the secular law originates from God.

\section{Notes}

1 The most recent overview of his life and work is Stone and West 2015. See also Stone 2013, pp. 28-45; Schrörs 1884; Anton 1968, pp. 281-355; Devisse 1976; Stratmann 1991; Patzold 2008, pp. 400-409.

2 By 'Augustinian', I refer to the thought that is manifested in Augustine's later work in particular the De civitate Dei. 


\section{Hincmar of Rheims}

3 J. Devisse remarks that Hincmar was more influenced by Alcuin's thinking before 860 than he was later in his life. Devisse 1976, p. 1354 (note 1). This might be due to Hincmar's upbringing and education at both Saint-Denis (under Abbot Hilduin) and the court of Louis the Pious.

4 AL vols. 1-4, Doppelfasz. 5/6 1986-2017.

5 Divinarum humanarumque rerum scientia. Epist. 307, p. 466, lin. 23.

6 A good summary of the content and purpose of the work is in Eichler 2011, pp. 121-148.

7 Schrörs 1884, pp. 440-442.

8 De Ord.Pal., p. 10; Schrörs 1884, pp. 440-441 (note 103).

9 De Ord.Pal., p. 34, 1. 17.

10 On the genre see Stone 2012, pp. 42-46.

11 Ibid, p. 11.

12 Ibid.

13 De Ord.Pal., p. 54, 1. $218 f f ;$ Schrörs 1884, pp. 440-442.

14 Ibid., p. 441.

15 Ibid.

16 De Ord.Pal., p. 11.

17 On the De ordine palatii see the brief analysis of Wallace-Hadrill 1975, pp. 193ff.

18 H. Schrörs assumes 869 to be the year of composition. Schrörs 1884, p. 388 (note 33).

19 Ibid., pp. 388-389 (including note 35).

20 Ibid., pp. 388-389 (note 35).

21 Ibid., p. 389 (note 35).

22 Migne 119, 536.

23 Schrörs 1884, p. 389 (note 35 ).

24 Ibid., pp. 388-389.

25 Devisse 1976, pp. 1351-1393.

26 Ibid., pp. 1358-1363.

27 Thus, before 860, the De civitate Dei must have been used chiefly in the context of Gottschalk's heretical doctrine of predestination. The role of Augustine in this discourse will be elucidated in the analyses of Epist. 37 (which contains the foreword, conclusion and notes to the Ad reclusos et simplices in Remensi parrochia contra Gothescalcum, Hincmar's first writing against Gottschalk on predestination, composed around 849-850) and Epist. 99 (a dedicatory letter for the lost extensive work against Gottschalk on predestination written between September 856 and early 857, which is an earlier version of Hincmar's De praedestinatione Dei et libero arbitrio from the beginning of 860 ). For Hincmar's texts on predestination, see also Ganz 1990, pp. 288, 298-299; Marenbon 1990, p. 304.

28 In all probability, the De civitate Dei is quoted in the De praedestinatione Dei et libero arbitrio, because Epist. 48 (from early 852), which is equally concerned with the controversy over predestination, also contains a direct reference to the De civitate Dei in a discussion of the role of the free will of man in predestination.

29 The analysis of Epist. 134 (which comprises Hincmar's foreword to the De divortio Lotharii regis et Theutbergae reginae from 860) should help illuminate Augustine's role in the argument made by Hincmar.

30 Devisse 1976, p. 1359.

31 Nelson 1986, pp. 170-171; Nelson 1994, pp. 66-69; Nelson 1996a, p. 97; Nelson 1996b, pp. 115-120. The Carolingian notion of unanimitas, based on Augustine's concerns, is evident in Wallace-Hadrill 1971, p. 105 and is explained in WallaceHadrill 1975, pp. 189f. On the purpose of the De regis persona et regio ministerio, see Wallace-Hadrill 1975, p. 193.

32 E. Perels mistakenly refers to Epist. 99 as the dedicatory letter of Hincmar's "zweite Schrift über die Prädestination.” Perels 1975, p. 44. According to Schrörs, however, 
Epist. 99 must belong to Hincmar's first extensive work on predestination, which is lost. Schrörs 1884, pp. 136-137. For Hincmar's texts on predestination, see also Ganz 1990, pp. 288, 298-299; Marenbon 1990, p. 304.

33 For Gottschalk on predestination, see Gillis 2017.

34 Schrörs 1884, p. 136 (note 27); Ganz 1990, pp. 288, 298; Marenbon 1990, p. 304.

35 Schrörs 1884, pp. 136ff.

36 Ibid., p. 136 (note 27); Ganz 1990, pp. 298-299.

37 Perels 1975, p. 46, 11. 2-10.

38 Ibid., p. 45-49.

39 Tavard 1996, pp. 22-23.

40 On Gottschalk's view of predestination, see the summaries in Ganz 1990, pp. 288, 296-297.

41 Gottschalk was a monk first of Fulda, then Reichenau, then Orbais. He had supporters until 866. For more biographical information see ibid., pp. 287, 301; Marenbon 1990, p. 304.

42 See Marenbon 1990, p. 304 and the summary in Tavard 1996, pp. 32-35. D. Ganz notes that engaging in theological controversy on a regional scale was only possible because patristic texts were easily and quickly accessible throughout the empire. In contrast to these texts, however, the treatises on predestination were hardly copied or disseminated. As a result, authors felt the need to quote extensively from the work they were criticising. Ganz adds that "the debate derived its momentum from the number of participants, not from the dissemination of treatises. These treatises were indeed written not for wide circulation but as dossiers for kings, bishops or councils." Ganz 1990, pp. 290-291. The paper by Ganz is a compelling study of this controversy from the perspective of the Carolingian clerical elite at a time of social crisis. Ganz shows how the debate brings to light the elite's different views of social order. By treating these views as "ideology," Ganz illustrates how this elite group defined its role as a "Heilsaristokratie ('aristocracy of salvation')." Ibid., pp. 286, 301-302.

43 See ibid., pp. 298-299.

44 See ibid., pp. 284, 289-291.

45 See ibid., pp. 290-291.

46 See ibid., pp. 289, 293-294; Marenbon 1990, pp. $311 \mathrm{ff}$.

47 Ganz 1990, pp. 286, 298-300.

48 Ibid., p. 298; Marenbon 1990, p. 314 (note 69).

49 See Ganz 1990, pp. 285-291, 295, 297-300, 302; Marenbon 1990, pp. 304-311.

50 See Ganz 1990, pp. 283, 287-289, 302; Marenbon 1990, pp. 304-312.

51 See Ganz 1990, pp. 286 (note 20), 289f., 295.

52 Ibid., pp. 285-286, 297-299.

53 Ibid., p. 298.

54 John Scotus' stance on predestination and free will, reflected in the De divina praedestinatione, is summarised in Ganz 1990, pp. 292-293 and comprehensively discussed in relation to Gottschalk's other opponents, Hincmar and Rabanus Maurus, in Marenbon 1990. Scholars seem to have differing opinions of the impact of John Scotus' work. While Devisse supports the view that the original and novel character of the work was not properly understood by Scotus' colleagues, J. Marenbon argues differently. Devisse 1976, p. 148; Marenbon 1990, pp. $303 \mathrm{ff}$. Marenbon integrates John Scotus into the contemporary debate and shows how members of the clerical elite did not only understand and engage with John Scotus' argument but also shared some of his opinions (e.g. Hincmar and Rabanus Maurus). Ibid., pp. 304-311. It becomes evident in his masterpiece, the Periphyseon, that John Scotus modified some of the ideas he earlier expressed in the De divina praedestinatione according to the criticism he had received by Prudentius of Troyes and Florus of Lyons. Ibid., pp. 311-325.

55 See the discussions in Ganz 1990, pp. 286ff., 297 and in Marenbon 1990, pp. $304 \mathrm{ff}$. 


\section{Hincmar of Rheims}

56 Perels 1975.

57 Ganz 1990, p. 297.

58 Ibid., pp. 298-300.

59 Perels 1975, p. 44; Schrörs 1884, pp. 136-137. For Hincmar's texts on predestination, see also Ganz 1990, pp. 288, 298-299; Marenbon 1990, p. 304.

60 Ganz 1990, p. 298; Marenbon 1990, p. 314 (note 69).

61 Ganz 1990, pp. 298-299.

62 On the decisions made at the Synod of Toucy (860), see ibid., pp. 286, 300-301.

63 The capitula of the Synod of Valence (855).

64 Emperor Lothar I requested the presence of fourteen bishops from the ecclesiastical provinces of Lyon, Vienne and Arles at the Synod of Valence (855).

65 The four capitula of the Synod of Quierzy (853) against Gottschalk.

66 Domno glorioso regi Karolo Hincmarus nomine non merito Remorum episcopus ac plebis dei famulus una cum collegis domnis et fratribus meis venerandis episcopis, oratoribus scilicet salutis atque prosperitatis vestrae devotis.

Deo gratias agimus, qui cor vestrum ad amorem suum accendit et ad cognitionem veritatis et ortodoxae fidei scientiam et diligentiam ignivit, prudentiam quoque et intellegentiam vobis in litteris divinitus inspiratis donavit et in earum meditatione atque exercitatione, quantum vobis pro rei publicae negociis licet, studium vestrae devotionis cotidiano augmento ad utilitatem sanctae suae ecclesiae provehit.

Ceterum capitula sinodalia venerabilium consacerdotum nostrorum, trium scilicet provinciarum, sicut ibidem continetur et inferius scriptum invenietur, vobis delata, quae nostrae humilitati iuxta scripturam praecipientem: 'Interroga sacerdotes legem meam', quia et legem fidei esse legimus, praecedentium regum more ob studium cognoscendae veritatis legenda et ventilanda dedistis, revolvimus. In quibus nos, licet nomina nostra sint tacita, designatione tamen effectus velut non catholicos reprehensos et sine fraternitatis respectu despectos reperimus. Capitula quoque, quae ob notam vobis et infra innotescendam necessitatem ex catholicorum patrum sensibus et verbis excerpsimus, velut inutilia, immo noxia, repulsa et abhominata invenimus. Quae capitula, sicut a nobis excerpta sunt, suis scriptis inserere noluerunt, ne ab illis legerentur, in quorum manus illorum capitula devenirent; sed quaedam de his, quae in capitulis a nobis excerptis habentur, alio sensu et aliis verbis tetigerunt, ut abhominanda illa monstarent, quaedam autem suppresserunt et taliter inde memoriam habuerunt, quasi nos contra sanctorum patrum sensa in Affricana et Arausica sinodo senserimus. Perels 1975, p. 44, 1. 17-p. 45, 1. 14.

67 Ibid., p. 45 (note 11).

68 Bishop Ibas of Edessa. At the Second Council of Constantinople (553), Emperor Justinian tried to produce proof that Ibas had denied the authorship of his letter to the Persian Maris at the Synod of Chalcedon (451). Ibid., p. 46 (notes 1-2).

69 By "rivals" (aemuli), Hincmar means the Semi-Pelagians.

70 In 431, Prosper travelled to Rome in order to ask Pope Celestine for a condemnation of Semi-Pelagianism, which was strongly represented in the monasteries of Provence. Pope Celestine then addressed himself to the Gallic bishops.

71 Inseruerunt etiam in eisdem suis scriptis de quibusdam XIX capitulis, quasi nobis debeant imputari, de quibus nil audivimus vel vidimus, antequam venerabilis Ebo Gratianopolitanus episcopus vobis ea, quasi a bonae memoriae fratre vestro Hlothario transmissa, apud Vermeriam palatium detulit. Quorum capitulorum auctorem nec ibi adnotatum invenimus nec, cum multum quaesierimus, invenire valuimus. Unde putavimus, quia alicuius inivdia ad cuiusquam opinionem infamandam fuerint compilata, sicut saepe legimus, ut de multis pauca commemoremus, veluti epistola capitulorum extitit, quam venerabilis Ibas episcopus suam esse in sinodo denegavit; et sicut quidam aemuli de verbis beati Augustini adhuc in sua vita fecerunt, quae ille arguit et catholice reppulit, quantum ad illius noticiam exinde pervenit. Post eius etiam obitum 
quidam invidi capitulum de eius ipsius scriptis, ex his etiam, unde nunc agitur, colligere curaverunt, ut illius doctrinam ortodoxam atque utillimam ob personae illius invidiam vilifacere praevalerent et lectores devotos ab illius lectione ac dilectione et necessaria credulitate averterent. Quae videlicet aemulorum mendacia ex delegatione sanctae sedis Romanae per Caelestinum papam sanctus Prosper catholico et prudenti stilo falsa esse et imprudenter obiecta ostendit et memorati ac memorandi viri doctrinam ortodoxam esse lucidissime demonstravit. Perels 1975, p. 45, 1. 26-p. 46, 1. 10.

72 See also the comment in Ganz 1990, p. 288.

73 Unde et fieri potest, ut ista capitula, quae vobis ex nomine confratrum nostrorum $\mathrm{ab}$ aliis quam ab illis delata vel transmissa sunt, taliter in suggillatione nostra conscripta non fuerint, sed instigante diabolo inter cetera mala, quae nunc in hoc mundo crebrescunt, ad immittendam inter Domini sacerdotes discordiam sint confecta, qui caritatem vehementer in nobis et timet et invidet, cum videt illam a nobis servari hominibus terrenis in terra, quam ille servare nolens angelicus spiritus amisit in caelo. Quomodo enim fieri posset, ut sic fratres nostri nos succensorie cum adnihilationis despectu iudicarent, qui regulam dominicam, qualiter confratrem quisque admonere debeat, continue prae oculis et in usu cotidie habeant? Scriptum enim esse cognoscunt: 'Priusquam interroges, ne vituperes quemquam et, cum interrogaveris, corripe iuste.' Sanctus enim Augustinus hereticorum et reprehensorum suorum scripta, si in eis quiddam bene dictum invenit, benignissime acceptavit et plura ad rectos sensus interpretari elaboravit, nulla autem de recto sensu ad pravum inclinare temptavit. Perels 1975, p. 46, 11. 11-23.

74 Archbishop Ebbo of Rheims' nephew Ebbo of Grenoble was the prime mover in the Synod of Valence (855). Ganz 1990, p. 298.

75 The capitula of the Synod of Valence (855).

76 Bishop Ebbo of Grenoble.

77 Et idcirco discredimus ista capitula ab eis confecta, quia praetermissis aliorum consacerdotum nominibus solius Ebonis nomen cum archiepiscopis est ibidem iactanter, ut quibusdam videtur, expressum. Et quod quam maxime ipse in hoc collaboraverit, quasi e regione sit sensum, ut etiam cum archiepiscopis maior ceteris et doctior in sententia fuerit, hoc enim de sancto Augustino, qui in conciliis Affricanis scientia et labore ac vigilantia maior extitit, nequaquam invenimus. Nam et ipse sanctus Augustinus non solum se ceteris coepiscopis privatam gloriam quaerens non praetulit nec praeferri permisit, verum se aliis supposuit, cum ipse plus aliis laboraverit, sicut in epistolis ad sanctum Innocentium papam scriptis et ad alios apostolicae sedis praesules qui legere voluerit invenire valebit. Nec de ullo episcoporum in ullis conciliis taliter legimus, nisi forte apostolicae litterae propter evidentem causam aliquem coepiscoporum ad hoc negocium cum archiepiscopo suo ex nomine designari decreverint, sicut de Augustidunensi episcopo in epistolis beati Gregorii legimus. Quanto magis iste religiosus et vir cautus in huiusmodi se efferre noluisset aut praeferri despectis ac praetermissis ceteris coepiscopis permisisset! Huc accedit, quia fratres nostri et consacerdotes surda aure non debuissent transire Salomonis dictum commonitorium, si ex nobis aut auditu aut scripto quiddam sinistri secreto accepissent, ut praepropere illud in publicum quacumque mobilitate nostra moti, unde non sumus conscii, ad contentiones et iurgia propalarent; ait enim: 'Quae viderunt oculi tui, ne proferas in iurgio cito, ne postea emendare non possis, cum dehonestaveris amicum tuum.’'Perels 1975, p. 47, 11. 12-31.

78 Between 877 and 878, Hincmar composed the Vita sancti Remigii episcopi Remensis, a hagiography of his predecessor St. Remigius. He was the first bishop of Rheims and is referred to as the Apostle of the Franks, since he baptised Clovis I, the first king of the Franks, in 496. His baptism resulted in the conversion of the Frankish people. In Epist. 99, St. Remigius is praised as a model of humilitas ("humility"). Ibid., p. 47, 11. $2 \mathrm{ff}$. 


\section{Hincmar of Rheims}

79 Theodore of Canterbury.

80 Emperor Charlemagne.

81 The Synod of Frankfurt (794).

82 Felix of Urgel.

83 Eorum etiam sententias, qui divina dignatione, postquam ipse canon a beato Gelasio conscriptus est, sensu et doctrina catholica et sanctitate conversationis in ecclesia floruerunt et ab ipsorum ortodoxorum patrum, qui in eodem canone adnotati sunt, fideli quia catholica doctrina nihil dissonum, nihil diversum scripserunt vel docuerunt, reverentia pari amplectimur, veluti venerabilis Bedae presbiteri a discipulis sancti papae Gregorii catholica fide imbuti et a sancto Theodoro archiepiscopo, utriusque linguae, Grecae videlicet et Latinae, perito et a sancta Romana ecclesia ad Anglos post discipulos beati Gregorii ad eruditionem transmisso, non mediocriter instructi ac venerandae memoriae Paulini patriarchae Aquileiensis parrochiae atque Alcuini viri religiosi et docti. Quorum fidem et doctrinam apostolica sedes Romana non solum benignissime acceptavit, verum et multis laudibus extulit, sicut in scriptis ipsius sanctae sedis invenimus, quae ecclesiae nostrae ab eadem ecclesiarum matre acceperunt tempore divae memoriae Karoli imperaoris, quando sinodus pro cognita infidelitate Felicis est habita et ad Romanam ecclesiam velut ad apicem ecclesiarum transmissa. Sed et eorum scripta qui legit, quam sint laudanda et recipienda, intellegit. Perels 1975, p. 49, 11. 1-16.

84 Perels 1975, p. 169, 1. 11, 1. 17.

85 Ibid., p. 168-171.

86 Ibid., p. 10, 1. 2.

87 Ibid., p. 16, 11. 9-10.

88 Ibid., p. $10,1.1$, p. $28,1.22$, p. $30,11.2-3$.

89 Gothescalco monacho, qui erat prolapsus in heresim, de quibusdam sententiis auctorum, quas ille non bene intelligebat vel exponebat, maxime Prosperi, quarum sensum per sententias precipue beati Augustini exponit, et ceteros idoneos proponit testes apostolicae fidei doctores; quorum sequendam in omnibus admonet esse doctrinam, ostenditque testimoniis manifestis Deum et bona prescire et mala, sed mala tantum prescire, bona vero et prescire et predestinare; unde et prescientia esse potest sine predestinatione, predestinatio autem non potest esse sine prescientia; et quia bonos prescivit et predestinavit ad regnum, malos autem prescivit tantum, non predestinavit nec ut perirent sua prescientia compulit. Ibid., p. 9, 1. 25-p. 10, 1. 7.

902 Pt 3:16.

91 Nam doctis et eruditis ista collectio necessaria non habetur et huiusmodi vulgaris locutio indigna videbitur, qui et in sensu suo gratias Deo habundant et sanctas scripturas atque sanctorum patrum catholicas exposiiones notas habent. Vos autem, cum quibus divina sapientia pro sancta simplicitate vestra loquitur, sicut scriptum est: 'Cum simplicibus sermocinatio eius', tamen, quoniam librorum copiam non habetis et istas oratorias tergiversationes non didicistis neque legistis unde si beatus Paulus ut mgnus orator in suis epistolis quaestiones proponit et nobis solvit et beatus Augustinus ac ceteri doctores contra hereticos pugnantes dialectice sund locuti: quae minus intelligentes, quando percontando, quando intentando, quando solvendo locuti sunt, 'depravant' bene dicta 'ad suam ipsorum perditionem', sicut beatus Petrus apostolus de epistolis sancti Pauli loquens dicit, tenete istam capitularem brevem et catholicam collectionem. Unde ex multorum patrum dictis multa colligi poterant. Sed quia id ipsum omnes secundum apostolum sentiunt et dicunt, quae breviter vobis ex paucorum nomine quaedam sensu, quaedam verbis ab eisdem expressis collecta sunt, pro sufficientibus habetote. Perels 1975 , p. 16, 11. $3-16$.

92 Ibid., p. 28, 11. 22-24, p. 30, 11. 1-6.

93 Ibid., p. 30, 11. 24-31. 
94 Quia praedestinatio, sicut beatus Augustinus dicit, a praemittendo et praeveniendo vel praeordinando futurum aliquid dicitur. Et ideo Deus, cui praescientia non accidens, sed essentia fuit semper et est, quicquid antequam sit praescit, praedestinat, et propterea praedestinat, quia quale futurum sit praescit. Mala enim tantum praescit, bona vero et praescit et praedestinat. Et alibi idem dicit: Praedestinatio est gratiae praeparatio et gratia est ipsa vitae donatio, id est praedestinationis effectus. Et homo, sicut longe superius diximus, non est factus neque praedestinatus a Deo, ut iret in ignem aeternum, neque ignis aeternus factus est propter hominem, sed propter diabolum, sicut dicit Dominus in evangelio: 'Qui praeparatus est diabolo et angelis eius'. Ibid., p. 17, 11. 25-33.

95 Praescientia est praecognoscentia, quod ante scitur quod eveniat vel quam fiat quod scitur; praedestinatio autem est, sicut sanctus Augustinus dicit, praeordinatio vel gratiae praeparatio, id est, sicut apostolus dicit: Electos praedestinavit Deus ad gloriam et praeparavit illos, id est praeordinavit, in fide, in bonis operibus, ut per illa ad gratiam remunerationis pervenirent, sicut scriptum est: 'Quae praeparavit Deus', scilicet bona opera, 'ut in illis ambulemus'. Haec est praedestinatio. Post praedestinationem autem et praeordinationem vel praeparationem Dei, quae est secundum propositum bonae voluntatis suae, nihil aliud sequitur, nisi praedestinationis effectus, id est gratia, quae est ipsa vitae donatio. Ibid., p. 19, 11. 13-21.

96 Sed ex massa peccati quosdam, sicut praescivit, praedestinavit, id est gratia praeparavit, ad vitam et regnum, et illis vitam ac regnum praedestinavit, id est gratia praeparavit, aeternum, evangelio teste, qui dicit: 'Venite, benedicti' id est de prima maledictione gratia erepti, electi et praedestinati , 'percipite regnum, quod vobis paratum est', id est quod vobis praedestinatum est, 'ab origine mundi'. Quosdam autem, sicut praescivit, non ad mortem neque ad ignem praedestinavit, sed in massa peccati et perditionis iuste deseruit, a qua eos 'praedestinatione' sua, id est 'gratiae praeparatione', occulto, sed non iusto iudicio nequaquam eripuit. Quia, sicut beatus exponit Augustinuns, 'praedestinatio est gratiae praeparatio; gratia autem est vitae donatio', id est 'ipsius praedestinationis effectus'. Et beatus Prosper, in hac re sancti Augustini expositor, cum ceteris orthodoxis concordans patribus dicit: Non est 'praedestinatio' nisi quod 'ad donum pertinet gratiae aut ad retributionem iustitiae'. Ibid., p. 28, 11. $14-24$.

97 Ibid., p. 29, 11. 29-35.

98 Ibid., p. 29, 11. 38-39.

99 Ibid., p. 30, 11. 1ff.

100 The pseudo-Augustinian Hypomnesticon.

101 Aliqua etiam exempla, quae illorum stultitia ad munimen sui eadem male intellegendo proferens profert, sicut modo ad memoriam occurrunt, sapientiae vestrae scribo. Proferunt ex apostolo 'vasa irae aptata' vel perfecta 'ad interitum', dicentes vasa esse praedestinata ad interitum et mutari non possunt. Sed aliter alii intellegunt, maxime cum idem dicat apostolus de eisdem vasis: 'Si quis emundaverit se ab istis', videlicet pro quibus vas contumeliae fuerat, 'erit vas in honorem'. Proferunt: 'Qui non credit, iam iudicatus est', id est praedestinatione Dei iam damnatus est. Et Augustinus in libro de agone Christiano dicit: 'Qui non credit, iam iudicatus est', id est 'iam damnatus est, praescientia utique Dei, qui novit, quid immineat non credentibus'. Proferunt: 'Induravit Dominus cor Pharaonis'. 'Tradidit illos in reprobum sensum', inmittet eis spiritum erroris. 'Tu vero Deus deduces eos in puteum interitus'. 'Qui transgreditur a iustitia ad iniquitatem, Deus paravit illum ad rompheam'.

Sed isti malivoli, non intellegentes quae locuntur vel de quibus affirmant, confundunt praescientiam et praedestinationem. Et sicut male intellegunt authenticas scripturas, ita et pessime verba sancti Augustini in quibusdam locis, sicut in enchiridion et in libris de civitate Dei et alibi praedestinatos ad interitum et populum natum ad iram dicit. Unde etiam postquam de libero arbitrio et de correptione et gratia et 
de perfectione iustituae hominis et de praedestinatione sanctorum ad Prosperum et Hilarum ubi nihil de praedestinatione reproborum, sed de praedestinatione sanctorum dixit multis postulantibus scripserat, librum ypomnesticon adversus Caelestium et Pelagium scripsit de quinque quaestionibus et hanc sextam loco retractationis superaddidit de praedestinatione. Ubi se excusat non eo sensu dixisse nec intellegi velle praedestinatos ad interitum, sed in inquitate vel impietate perseverantibus poenam esse praedestinatam. Quarum quaestionum et absolutionum mentionem in libro, quem scripsit contra Manicheos ex Genesi, facit. Perels 1975, p. 29, 1. 24-p. 30, 1. 9.

102 In the newest edition, to which I adhere, the content of this writing appears as the praefatio to Hincmar's De divortio Lotharii regis et Theutbergae reginae. See De divort. Loth.

103 An overview of the 'church's' struggle against divorce is provided in Le Jan 1995, pp. 277-285. See also the recent article by Bof and Leyser 2016, pp. 155-180. For an extensive treatment of the case, see Stone and West 2016; Heidecker 2010. A discussion of the case with regard to the themes of private and public is given by Airlie 1998. The analysis of the private and public spheres concentrates on the representation of Christian royalty and the role gender played in the case. On the relationship between a king and a queen, S. Airlie concludes: "A king who could not rule his own body was unworthy to rule his kingdom, just as a queen who could not rule her body was unworthy to be a wife. King and queen may thus have been seen in the Carolingian era as points on a scale of values rather than as strictly gender-separated offices." Ibid., p. 33.

104 Schrörs 1884, p. 195.

105 Ibid., p. 204.

106 Ibid., p. 205.

107 Ibid., p. 203.

108 Ibid., p. 196.

109 Ibid., p. 195.

110 See J. L. Nelson's argument in Nelson 1986, pp. 140, 142.

111 Schrörs 1884, p. 193. Augustine's reflections on law are summarised by R. A. Markus 1988, pp. 110-111.

$112[\ldots]$ necesse est et ecclesiasticis et publicae rei iudicibus, ut ita sub oculis superni iudicis in quacumque causa et de quacumque persona decernant iudicium [...]. De divort. Loth., p. 109, lin. 22.

113 Schrörs 1884, p. 203.

114 On Louis the Pious, see the analysis in Arquillière 1934, pp. 170ff. and Chapters 5 and 6 in De Jong 2009. The function of his penance is summarised in Wallace-Hadrill 1971, pp. 124-125.

115 Schrörs 1884, p. 193.

116 [...] sanctus Augustinus in libro quarto contra Iulianum dicit: Nos certe, si eos, in quos nobis potestas est, ante oculos nostros perpetrare scelera permittamus, rei cum ipsis erimus.

Quam vero innumerabilia ille permittit fieri ante oculos suos, quae utique, si noluisset, nulla ratione permitteret?

Et tamen iustus et bonus est et, quod post patientiam dat locum poenitentiae, nolens aliquem perire.

Quod cur fiat, sanctus demonstrat Gregorius exponens scripturae testimonium: Altissimus est enim patiens redditor, quoniam et patitur mala nostra et reddit.

Nam quos diu, ut convertantur, tolerat, non conversos durius damnat. De divort. Loth., p. 113, lin. 36-p. 114, lin. 3.

117 Nelson 1986, p. 139.

118 The phrase is borrowed from D. Erdozain's article on sin in the nineteenth century. Erdozain 2011. 
119 This is also the view of Anton 1968, pp. 307, 329. On the episcopal jurisdiction over the consecrated king, see Nelson 1986, pp. 140, 142.

120 An interesting but rather bold argument by M. J. Wilks may be able to delineate and explain a certain reading of Augustine that might have prompted Hincmar to have recourse to Augustine in this context. Wilks' fundamental proposition is that, when setting forth the doctrine of the two civitates, Augustine "was not juxtaposing Church and State, but comparing Christian and non-Christian empires." Wilks 1967, p. 493. Although he argues that for Augustine iustitia was a pre-eminently divine quality, he assumes that Augustine in fact conceived a realisation of iustitia in a fully Christian setting. Wilks writes that, according to Augustine, it was ultimately the lack of iustitia among the heathen Romans that had prevented them from achieving a res publica. Ibid., pp. 491, 493. Wilks maintains: “... Augustine's point was that ... from a Christian viewpoint ... all these Roman virtues were vitiated by the lack of iustitia, something which could only be understood in terms of the Christian way of life and operated within the context of a Christian society." Ibid., p. 493. Wilks even goes so far as to suggest that, in Augustine's eyes, "the Christian society had taken over the Roman empire and converted it into an empire of Christ, coterminous with the visible Church, the civitas Dei on earth." Ibid., p. 499. On this theoretical basis, Wilks develops his broader argument against the scholarship influenced by H.-X. Arquillière that sees the millenium between Augustine's death and the Aristotelian revolution as "... a period of development completely out of line with Augustinian theory, the age of political Augustinianism, a bastardisation of true Augustinian principles ...." Ibid., p. 490. Wilks considers it wrong to assume that the papal-hierocratic model is not representative of an important continuation and enhancement of Augustine's thinking: he suggests an "all-pervasive teleological cast of Augustine's mind" which "... is a cardinal feature of the Platonism which characterises his whole outlook." Ibid., p. 491. Wilks claims that it was characteristic of Augustine's attitude of mind to think about the purpose towards which an institution should be directed. He also writes that "... iustitia as giving each his due exemplifies Augustine's deliberate attempt to suggest a continuity of Christian theory from the natural law of the classical Roman philosophers." Ibid. Consequently, according to Wilks, it is Augustine who is the true deviser of the idea that institutions like royal power needed "... direction by the priesthood as the divine element in the community which alone had the proper understanding of divine things." Ibid., p. 499. Wilks presents Augustine as the thinker who prepared the framework of the auctoritas Ecclesiae, the thought that it is the bishops who rule over the secular leadership and over the lay members of society. Ibid., pp. 502-503. Thus, by referring to the inheritor Gelasius, Wilks concludes: "Whilst Augustine cannot be said to have stressed the opposition between episcopal auctoritas and royal potestas in the same outspoken manner as Gelasius later in the century, he cannot, as a student of Cicero, Roman law and the Bible, have settled on this distinctive terminology by accident." Ibid., p. 503. On Gelasius' scheme of subordination and his formulation of the role of the secular ruler in the 'church', see also Markus 1988, pp. 101-102.

121 Qua de re, licet hoc quibusdam valeat displicere, si forte sunt, qui magis eligunt sequi quod eis libenter libet, quam quod licenter licet, faciam quod iubetis, sciens ab apostolo commendatum, ut 'omnis anima', id est omnis homo, 'potestatibus sublimioribus subdita sit; non est enim potestas nisi a Deo'; et iterum dicit: 'Subiecti estote omni humanae creaturae propter Deum sive regi tamquam praeccellenti'.

Et quoniam vestra regis a Deo constituta sublimitas sacerdotali religioni et cordis et corporis cervices devote inclinat, competens esse dinoscitur, ut et pontificalis auctoritas regiae dignitati cum omni pietatis officio se submittat, sicut sanctus Gelasius in decretali epistola ad Anastasium imperatorem ostendit dicens: 'Duo sunt quippe, imperator auguste, quibus principaliter mundus hic regitur: auctoritas sacra pontificum et regalis potestas; in quibus tanto gravius pondus est sacerdotum, quanto etiam 
pro ipsis regibus hominum in divino reddituri sunt examine rationem'. Hinc, 'quantum ad ordinem publicae pertinet disciplinae, cognoscentes imperium tibi superna dispositione conlatum, legibus tuis ipsi quoque parent religionis antistites, ne vel in rebus mundanis exclusae videantur obviare sententiae'; et alibi: 'Quoniam sic Christus, memor fragilitatis humanae, quod suorum saluti congrueret, dispensatione magnifica temperavit, sic actionibus propriis dignitatibusque distinctis officia potestatis utriusque discrevit, suos volens medicinali humilitate salvari, non humana superbia rursus intercipi, ut et Christiani imperatores pro aeterna vita pontificibus indigerent et pontifices pro temporalium cursu rerum imperialibus dispositionibus unterentur, quatenus spiritalis actio a carnalibus distaret incursibus et ideo militans Deo minime se negotiis saecularibus implicaret, ac vicissim non ille rebus divinis praesidere videretur, qui esset negotiis saecularibus implicatus, ut et modestia utriusque ordinis curaretur, ne extolleretur utroque suffultus, et competens qualitatibus actionum specialiter professio aptaretur'. Et sanctus Augustinus in sermone VI. evangelii Iohannis dicit: 'Leguntur enim leges manifestae, ubi praeceperunt imperatores eos, qui praeter ecclesiae catholicae communionem usurpant sibi nomen Christianum nec volunt in pace colere pacis auctorem, nihil nomine ecclesiae audeant possidere'. 'Sed quid nobis', inquiunt, 'et imperatori?' 'De iure humano hoc agitur, et tamen apostolus voluit serviri regibus, voluit honorari reges et dixit: 'Regem reveremini'. Noli dicere: Quid mihi et regi? Quid tibi ergo et possessioni? Per iura regum possidentur possessiones'; et in sermone VII.: 'Iuris enim forensis est, ut qui in petitionibus mentitus fuerit, non illi prosit quod inpetravit. Dixisti enim quod voluisti et cui dixisti; nescit an verum sit; dimisit te adversario tuo convincendum, ut, si ante iudicem convictus fueris de mendaacio, ibi careas ipso beneficio rescripti, quo perduxisti rescriptum'. Et sacri canones atque decreta pontificum Romanorum multoties pro honore et statu ecclesiae apud reges satagere nos debere ostendunt, sicut qui legerit invenire valebit. Et beatus Gregorius commonitorium ad Iohannem defensorem euntem in Hispanias totum de legibus imperialibus ad correctionem et constitutionem ecclesiasticarum sanctionum composuit. Et Toletantum concilium in causarum diffinitione 'legum et canonum sententias' iubet 'exquiri'. Oboediendum ergo nobis regibus pietatis cultui et religione et iure et solatio servientibus. Perels 1975, p. 53, 1. 7-p. 54, 1. 12.

122 This is clarified in Anton 1968, pp. $311 \mathrm{ff}$.

123 Nelson 1986, p. 139.

\section{Bibliography}

\section{Primary sources}

Ernst Perels (ed.): Hincmari archiepiscopi Remensis epistolae: Die Briefe des Erzbischofs Hinkmar von Reims. München, 1975.

Hincmarus Archiepiscopus Rhemensis: De ordine palatii. Thomas Gross and Rudolf Schieffer (eds.) (Fontes iuris 3). Hannover, 1980.

Hincmarus Remensis: De divortio Lotharii regis et Theutbergae reginae. Letha Böhringer (ed.) (MGH Conc. 4 Suppl. 1). Hannover, 1992.

Hincmari Rhemensis archiepiscopi opera omnia. Juxta editionem Sirmondianam ad prelum revocata/accurante J.-P. Migne. Turnhout, 1966-1969.

\section{Secondary sources}

Airlie, Stuart: Private Bodies and the Body Politic in the Divorce Case of Lothar II. Past and Present: A Journal of Historical Studies 161, 1998, 3-38. 
Anton, Hans Hubert: Fürstenspiegel und Herrscherethos in der Karolingerzeit. Bonn, 1968.

Arquillière, H.-X.: L'Augustinisme politique: Essai sur la formation des théories politiques du Moyen-Âge. Paris, 1934.

Bof, Riccardo and Leyser, Conrad: Divorce and Remarriage between Late Antiquity and the Early Middle Ages: Canon Law and Conflict Resolution, in: Kate Cooper and Conrad Leyser (eds.): Making Early Medieval Societies: Conflict and Belonging in the Latin West, 300-1200. Cambridge, 2016, 155-180.

De Jong, Mayke: The Penitential State: Authority and Atonement in the Age of Louis the Pious, 814-840. Cambridge, 2009.

Devisse, Jean: Hincmar: Archevêque de Reims 845-882. Genève, 1976.

Eichler, Daniel: Karolingische Höfe und Versammlungen - Grundvoraussetzungen, in: Matthias Becher and Alheydis Plassmann (eds.): Streit am Hof im frühen Mittelalter Super alta perennis: Studien zur Wirkung der Klassischen Antike XI, 2011, 121-148.

Erdozain, Dominic: The Secularisation of Sin in the Nineteenth Century. The Journal of Ecclesiastical History 62(1), 2011, 59-88.

Ganz, David, The Debate on Predestination, in: Margaret Templeton Gibson and Janet Laughland Nelson (eds.): Charles the Bald: Court and Kingdom. (2nd revised ed.). Aldershot, 1990, 283-302.

Gillis, Matthew Bryan: Heresy and Dissent in the Carolingian Empire: The Case of Gottschalk of Orbais. Oxford, 2017.

Heidecker, Karl: The Divorce of Lothar II: Christian Marriage and Political Power in the Carolingian World. Ithaca and London, 2010.

Le Jan, Régine: Famille et pouvoir dans le monde franc (VIIe - Xe siècle): Essai d'anthropologie sociale. Paris, 1995.

Marenbon, John: John Scottus and Carolingian Theology: From the De Praedestinatione, Its Background and Its Critics, to the Periphyseon, in: Margaret Templeton Gibson and Janet Laughland Nelson (eds.): Charles the Bald: Court and Kingdom. (2nd revised ed.). Aldershot, 1990, 303-325.

Markus, Robert Austin: The Latin Fathers, in: James Henderson Burns (ed.): The Cambridge History of Medieval Political Thought c. 350-c. 1450. Cambridge, 1988, 92-122.

Nees, Lawrence: Carolingian Art and Politics, in: Richard Eugene Sullivan (ed.): The Gentle Voices of Teachers: Aspects of Learning in the Carolingian Age. Columbus, 1995, 186-226.

Nelson, Janet Laughland: Politics and Ritual in Early Medieval Europe. London, 1986.

Nelson, Janet Laughland: Kingship and Empire in the Carolingian World, in: Rosamond McKitterick (ed.): Carolingian Culture: Emulation and Innovation. Cambridge, 1994, $52-87$.

Nelson, Janet Laughland: Translating Images of Authority: The Christian Roman Emperors in the Carolingian World, in: Janet Laughland Nelson (ed.): The Frankish World, 750 900. London and Rio Grande, 1996a, 89-98.

Nelson, Janet Laughland: The Lord's Anointed and the People's Choice: Carolingian Royal Ritual, in: Janet Laughland Nelson (ed.): The Frankish World, 750-900. London and Rio Grande, 1996b, 99-131.

Nelson, Janet Laughland: 'Not Bishops' Bailiffs but Lords of the Earth': Charles the Bald and the Problem of Sovereignty, in: Janet Laughland Nelson (ed.): The Frankish World, 750-900. London and Rio Grande 1996c, 133-143. 


\section{Hincmar of Rheims}

Patzold, Steffen: Episcopus: Wissen über Bischöfe im Frankenreich des späten 8. bis frühen 10. Jahrhunderts. Ostfildern, 2008.

Schrörs, Heinrich: Hinkmar, Erzbischof von Reims: Sein Leben und seine Schriften. Freiburg i. Br., 1884.

Stone, Rachel: Morality and Masculinity in the Carolingian Empire. Cambridge, 2012.

Stone, Rachel: Gender and Hierarchy: Archbishop Hincmar of Rheims (845-882) as a Religious Man, in: Patricia H. Cullum and Katherine J. Lewis (eds.): Religious Men and Masculine Identity in the Middle Ages. Woodbridge, 2013, 28-45.

Stone, Rachel and West, Charles (eds.): Hincmar of Rheims: Life and Work. Manchester, 2015.

Stone, Rachel and West, Charles: The Divorce of King Lothar and Queen Theutberga: Hincmar of Rheims's De Divortio. Manchester, 2016.

Stratmann, Martina: Hinkmar von Reims als Verwalter von Bistum und Kirchenprovinz. Sigmaringen, 1991.

Tavard, George Henry: Trina Deitas: The Controversy between Hincmar and Gottschalk. Milwaukee, 1996.

Wallace-Hadrill, John Michael: Early Germanic Kingship in England and on the Continent: The Ford Lectures Delivered in the University of Oxford in Hilary Term 1970. Oxford, 1971.

Wallace-Hadrill, John Michael: The Via Regia of the Carolingian Age. in: Idem (ed.): Early Medieval History. Oxford, 1975, 181-200 (first published Oxford, 1965, 22-41).

West, Charles: Lordship in Ninth-Century Francia: The Case of Bishop Hincmar of Laon and His Followers. Past and Present: A Journal of Historical Studies 226, 2015, 3-40.

Wilks, Michael John: Roman Empire and Christian State in the De Civitate Dei. Augustinus $12,1967,489-510$.

\section{Dictionaries and lexica}

Mayer, Cornelius Petrus et al. (eds.): Augustinus-Lexikon vols. 1-4, Doppelfasz. 5/6. Basel, 1986-2017. 


\section{Hincmar's indirect use of Augustine His 'Expositiones ad Carolum Regem' and 'De regis persona et regio ministerio'}

\section{Hincmar's Expositiones ad Carolum Regem}

In the spring of 868 , a disagreement broke out between Charles the Bald and Bishop Hincmar of Laon, the nephew of Hincmar of Rheims. ${ }^{1}$ In this confrontation, which resulted in a legal dispute, Hincmar of Rheims took sides with his nephew and wrote three legal opinions for the Synod of Pîtres in 868: the so-called Quaterniones, defending the 'church' property against Charles the Bald's claim; the so-called Rotula, providing supplementary legal evidence and the Admonitio, drawing the king's attention to the commitments he had made to the 'church'.

As far as the written tradition of the Expositiones ad Carolum Regem is concerned, it is worth asking why these three texts have been preserved. First of all, Reims was - not only in geographical terms - the most influential archdiocese in Western Francia. Secondly, between 865 and 870 the library and archives of Rheims were restructured. ${ }^{3}$ This was partly the result of Hincmar's realisation of the importance of keeping a complete record of the files. His defeat in the conflict of authority with Rothad of Soissons in 865, and the difficulties with Rome that this entailed, played a crucial role in this enterprise. He would henceforth make a particular effort to store all the documents concerning ecclesiastical law. ${ }^{4}$ Accordingly, the three texts that constitute the Expositiones ad Carolum Regem were also recorded. Another reason why these legal opinions have been preserved and had become relevant for the entire Middle Ages is that Hincmar appears as a radical apologist for the liberties of the 'church'. The work provides a first-rate example of a legal defence of ecclesiastical privileges against usurpation by secular power.

The cause of the dispute of 868 was one of the many incidents relating to 'church' property that mark the ninth century. At the request of Bishop Hincmar of Laon, Charles the Bald handed over a villa to him, which had recently been confiscated. Hincmar the Younger immediately gave it as a benefice to the king who then installed a faithful man by the name of Nortmann in the villa. Charles would then continually accuse the bishop of trying to seize five fiscal manses, in addition to the land rightly returned, while the bishop would in turn accuse Nortmann of being a raptor facultatum ecclesiasticarum for having taken back these five manses. The result of this conflict was the deposition of Bishop Hincmar of Laon. 
In 868 , the king summoned Hincmar of Laon to appear in person before the royal tribunal or be represented by an intermediary. He accused the bishop of having made abusive confiscations of benefices dependent on his diocese and entrusted to certain men of the king. No bishop, not even the archbishop, was informed about the summons Hincmar the Younger had received. His refusal to appear was then punished by the seizure of the bishop's revenues through Nortmann.

When Hincmar of Rheims learned about the incident, he carried out a detailed investigation and prepared a dossier to be given to the king at the Synod of Pitres in the summer of 868. The two texts submitted in August were the Quaterniones and the Rotula. However, Charles the Bald decided to postpone the reading and intended to demand that the bishops give account if they confiscate benefices from the holders. Thereupon, Hincmar of Rheims pronounced an allocution, the Admonitio, in order to force the king to acknowledge his dossier.

The prelate's survey found, among other things, evidence of unacceptable actions taken by Charles the Bald. Furthermore, it exposed the pretext for the rapid escalation of the judicial process; passing through the lands of Laon, the king received a complaint against Bishop Hincmar of Laon from the son of a certain Liudon. As was confirmed by the bishop, this boy should have received the benefice held by his father in exchange for a gift. However, for no apparent reason, Hincmar of Laon then revoked the concession. Enraged by what he had heard, the king publicly insulted the bishop. Hincmar of Laon did not appear before the royal court, and the king made him pay a fine despite his apologies for absence. Having repeatedly asked for the bishop's advocate in vain, Charles the Bald finally ordered the confiscation of all the secular goods of Laon, with the exception of the cathedral, the residence of the bishop and the cloister of the clerics. The Count of Laon placed the property under the royal ban. Hincmar writes at the beginning of the Quaterniones where he provides a description of the facts:

Since his [Bishop Hincmar of Laon's] advocate had both been required and not been found, who should have given an account of his [Bishop Hincmar of Laon's] offence for the aforesaid reason, with the exception of the 'church' and the house of the bishop, as well as the cloister of the clerics, everything he had accepted of the property and ecclesiastical goods commissioned to him at the episcopal ordination as a gift of the Holy Spirit to manage and distribute has been banned, at your command, by the viscount of the county itself which is legally called 'proscription by confiscation' in the Latin language. ${ }^{5}$

The royal chancellor had informed Hincmar of Rheims in detail about the steps taken by the king in order to achieve the bishop's capitulation. It had never happened before that a bishop had been stripped of his property by a judgment of laymen without an ecclesiastical agreement. This is made clear somewhat further below in the Quaterniones:

For it is new what has been done now, since it has never been heard under this sky, that a bishop has been expropriated with his 'church' under the title 
of 'proscription' by any religious leader, in a judicial investigation of laymen, after Emperor Constantine the Great had made a law for the entire body of clerics, saying: "Constantine greets the clerics. Beside the confirmation of inviolability that you have been asserted to have earned not long since, no one will restrain your lands and ecclesiastical tributaries by new collections, instead you will take pleasure in immunity." For, since he says "no one", no one is excluded; certainly, in this comprehension the leading power is also included. ${ }^{6}$

Hincmar wants to make explicit that the ruler, as well as any of his direct officials, are included in this clause.

All the texts the prelate gathered for the Quaterniones condemn the procedure followed by the king. Hincmar of Rheims lays out the entire legislation on ecclesiastical goods in order to remind Charles the Bald of the promises he made with regard to their protection. Hincmar adds some canonical texts that condemn a confiscation of the kind undertaken by the king. Furthermore, by using four pieces of Roman law as well as the Pseudo-Isidorian Decretals, he establishes an inviolable principle on the trial of clerics; a cleric cannot be summoned before a secular court. ${ }^{7}$ The civil law and the canon law have commonly agreed that the 'church' will indict any bishop who has accepted to be judged by a layman. No one can seize the episcopal property - especially not in the absence of any legal ruling.

As far as the case of Liudon and his son is concerned, Hincmar finds that it is proper that these homines militares who receive the benefices serve both the king and the 'church'. When a son follows a man who has conscientiously fulfilled this double duty, the transfer of the benefice to the son is conventional. If a dispute arises between the homo militaris and the bishop, and all avenues of reconciliation have been explored, it is normal that the layman brings the appeal before the king. Up to that point, according to Hincmar, the procedure had been lawful. However, it was the king's reaction to the complaint that was immoderate. First of all, the integrity of the 'church' property should have been protected. Secondly, missi should have been sent by the king in order to investigate discreetly. After the investigation, the case should have been brought before an ecclesiastical tribunal. Canon law would have been applied to the cleric, the capitularies to the layman. ${ }^{8}$

The prelate's principal statement is that only a careful observance of the law can provide a solution to the matter and that Charles the Bald, although king, is wrong to believe that he is above the law. The Rotula was essentially an aidemémoire highlighting particular points made in the Quaterniones (mostly with regard to the rules of judgment when the accused is a bishop). After Charles the Bald had dismissed both texts and insisted on having his own rights respected, the Admonitio reminded him more rigorously of his duties. The basic argument remained the same; the king is a prisoner of the texts. The predecessors of Charles the Bald made a point of respecting the laws their predecessors had respected and those they signed themselves. ${ }^{9}$ Hincmar of Rheims indicated to the king that he himself, through his own concessions, had multiplied these promises of respect for the 'church', its members and its property. 
The first part, the Quaterniones, comprise all the explicit and implicit references to Augustine of Hippo (of which there are five explicit references in total) present in Hincmar's Expositiones ad Carolum Regem. No further references to Augustine can be found in the Rotula or the Admonitio. While the Admonitio has a purely monitory function and the Rotula merely gives additional evidence from canon law, the Roman law enforced by the Christian Roman emperors and from Carolingian capitularies, the Quaterniones contain the main argument of Hincmar's legal opinion. For this reason, only the Quaterniones of the Expositiones ad Carolum Regem will be considered in my research.

In terms of originality and individuality, the Expositiones ad Carolum Regem are probably Hincmar's most interesting piece of writing. They are written from the author's point of view and are Hincmar's personal statement in response to infringements of the libertates ecclesiae. ${ }^{10}$ In this regard, the Expositiones ad Carolum Regem seem to form a counterpart to the De regis persona et regio ministerio, which (like Hincmar's other works) only contains a little of his own original work. Although intriguing because it draws heavily on Augustine and is interspersed with long quotations from the De civitate Dei, the De regis persona et regio ministerio does not comprise an original engagement with the source material it uses. Its lengthy quotes are often only loosely connected to the subject matter.

A number of questions will guide the investigation of the Quaterniones. The main question that is asked in the Quaterniones itself concerning a legal dispute that involves both the 'state' and the 'church' is: how does the secular law relate to the 'church' that is affected (i.e. accused) in this case? The main questions that will be posed with regard to Augustine's influence are: where in the text, in what context(s) and how often compared to other authors and sources is Augustine used explicitly and/or implicitly? For what purposes? To make what kind of statements? Of what nature are the explicit and implicit references to Augustine? What place does Augustine take in this legal opinion? As part of the search for implicit evidence of Augustine's influence, a formal analysis of the Quaterniones will look at the following concepts: iustus/iustitia (taking into consideration Hincmar's references to Theodosius I and Theodosius II), beatus/beatitudo vs. (in)felix/(in)felicitas, superbus/superbia as opposed to humilis/humilitas (in various rulers, including King David, who has sinned like King Charles the Bald) and misericors/misericordia. In terms of intertextuality and performativity, further enquiries will be made, such as: in what way does Hincmar refer to the (Christian) Roman emperors and the Frankish predecessors as well as contemporary rulers of Charles the Bald (compared with Alcuin of York's Epist. 246 directed to Archbishop Theodulf of Orléans, which was composed after Charlemagne's imperial coronation and associates Charlemagne with the Roman imperial tradition)? What aim does the author pursue by referring to these previous rulers? Is there any criticism involved? What are the roles of Charlemagne and Paulinus II of Aquileia (compared with Alcuin's Epist. 139 directed to Paulinus, which contains a powerful link between Charlemagne as an Old Testament king and the civitas Dei), Emperor Theodosius I and Bishop Ambrose as well as King David in the 
Quaterniones? What is the meaning of the closing of the Quaterniones together with the direct references to Augustine? It will be seen that in the Quaterniones, Augustine emerges in particularly interesting and important places of the text.

In the explanatory section at the beginning of the Quaterniones, Hincmar repeatedly emphasises the outrageousness of the fact that Bishop Hincmar of Laon is made answerable to a secular tribunal by Charles the Bald. He writes:

Then you have ordered the aforementioned bishop to come to your cause, that is, to the secular court, on the designated day and place: and that he would present his advocate of his offence, naturally of his act which he has committed himself, that is, with some fellow bishop of whom I am not aware. This one has commissioned [put into writing], sending an excuse to your lordship for the impossibility of him coming there. What we name an excuse in the indigenous language has been required, since he was unable to come: which has hitherto been unheard of. ${ }^{11}$

Right at the beginning of his criticism, Hincmar voices the opinion that Charles the Bald has imposed too heavy penalties on Hincmar of Laon. He acknowledges Charles the Bald's good intentions, but at the same time warns that rumours about his decisions will circulate in remote areas where his essentially good intentions will be misunderstood. Hincmar chooses the following words:

And although, in view of the religious observance of your Christianity, one has to believe that you have carried this out for the correction of the bishop himself, your wisdom still has to be wondered at, which has thus measured the medicine for a [Hincmar of Laon's] wound so that it was itself wounded from the medicine. The Lord sets the standards of the love of neighbour thus, that we love the neighbour as ourselves and do not love ourselves more. Fame - or, more precisely, infamy - penetrating Burgundy and Provence, as well as Italy, will reach Rome; and through the realm of your grandson, will not only come to nearer Germania, but also to the more remote parts; it will occupy Aquitania and Septimania, rushing through Neustria. And whoever does not know the sincere eye - that is to say the good intention - that is in you will think that where something is done contrary to the Lord, and hostile to the sacred canons (just as the blessed Leo writes, constructed by the Holy Spirit and consecrated to the reverence of the entire world, whose founders reign in heaven with the Lord, and sparkle on earth with miracles, live to this day together with us in the constitutions), and also even to the laws, by which together with the same sacred canons the 'church' is regulated - they will think that where something like this is done, it is without doubt adverse [to the Lord]. ${ }^{12}$

After the statement already mentioned above - that it is unprecedented that a bishop is summoned before a secular court - Hincmar starts listing major laws adopted by previous rulers. He remarks that a law enforced by Constantine I has 
been confirmed by the emperors Constantius II (a dedicated promoter of Arianism) and Constans, who have both granted the 'church' immunity. ${ }^{13}$ Also, the emperors Valentinian I and Valens have similarly decreed that nothing concerning the ecclesiastical privileges can be changed. ${ }^{14}$ Thereafter, according to Hincmar's account, these laws have indirectly been validated by the emperors Arcadius and Honorius, who have claimed: "Concerning the sacred 'churches', we order that whatever, they say, has been set up by our ancestors in different times, remains inviolable and incorruptible." ${ }^{15}$ The meaning of this precept in simple words is that whatever has been enacted by a predecessor cannot be repealed by a successor.

Before we discuss Hincmar's consideration of the Christian Roman empire and emperors in the Quaterniones, two thought-provoking passages from the De civitate Dei must be recalled. They are drawn from Chapters 24 and 26 of Book V of the De civitate Dei, where Augustine judges the Christian Roman 'state' and praises some of its leaders (emperors Constantine I and Theodosius I) within reasonable limits. Regarding the Christian emperors at large, Augustine first declares that it would be wrong to consider some of them successful and lucky because they managed to overcome enemies of the 'state' and rebels and had a long and contented reign and a peaceful death. For even demon worshippers enjoy the benefit of such comforts. Rather, they must be called happy if they govern justly and with the right measure of forbearance under God's authority, if they do not forget that they are human too, if they honour God and the Kingdom of God, if they live a modest, virtuous and pious life and do not wage unnecessary wars or conquer unnecessarily and, finally, if they do all this not for any kind of human recognition but in humility before God, for the love of God. ${ }^{16}$ In this extract (as well as in the last paragraph of Chapter 19 in Book V of the De civitate De $i^{17}$ ), proof can be found that Augustine sees emperors in general as subordinate to God. However, at the same time, these lines also disclose that Augustine still holds a certain passion for temporal greatness and thinks of Christian emperors as particularly felices ("happy"). In the second passage, Theodosius I is praised above all for his piety and humility. Augustine expresses admiration for Theodosius I's strong Christian belief, his strict prohibitions on heathen practices ${ }^{18}$ and his contributions to the consolidation of the Christian 'church' on earth. Great emphasis is placed on the emperor's humility due to his willingness to forgive and repent after having punished the Thessalonians excessively for committing a crime. Augustine also does not fail to mention the group of bishops (to which Ambrose belonged) who encouraged the emperor's noble gesture of penitence. ${ }^{19}$ His judgment of Emperor Theodosius I is as follows:

But what was more admirable than his [Theodosius I's] religious humility, when, by the protest of some who adhered to him, he was urged to take vengeance for the very grave crime of the Thessalonians, for which he had already promised indulgence since the bishops interfered, and corrected by the ecclesiastical instruction thus exercised penitence, so that the people praying for him shed more tears when seeing the imperial sublimity prostrated, than it feared the imperial sublimity enraged when sinning? 
He carried these good deeds - as well as others like it, which would be tedious to recount - with him out of this temporal society of any high quality and human sublimity; the reward for which deeds is eternal happiness, whose giver is God to the truly pious alone. ${ }^{20}$

The first time Theodosius II and his laws are mentioned in the Quaterniones is when Hincmar suggests that Charles the Bald read the Codex Theodosianus. Hincmar observes:

Many things could still be laid out here, which have been preserved by all those who are advantageously reigning, and justly judging for a long period of time; but I know that your wisdom is bound to understand most of these things which have been laid out from the sixteenth book of the Theodosian law. ${ }^{21}$

Immediately after the Codex Theodosianus has been recommended to Charles the Bald, a link is made from the laws of the Christian Roman emperors to those of the Frankish predecessors as well as contemporary rulers of Charles the Bald; Charlemagne is mentioned as the linking element between the Christian Roman and the Frankish rulers, of whom the Carolingians are the only ones mentioned. The Merovingians are excluded from this tradition for the purpose of entirely breaking the link between the notion of rulership of the Christian Carolingians and that of their ancestors with pagan, Germanic roots. Furthermore, Charlemagne and Paulinus II of Aquileia play the key roles in a praeiudicium ("prejudgment") made by Charlemagne concerning the ecclesia res (which here clearly has the literal meaning of "“church' property"). ${ }^{22}$ The result is the publication of an edict, signed by Charlemagne (for his successors to adhere to), at the instigation of Paulinus and other bishops. According to Hincmar, a part of this edict can be found in the book of the imperial Capitularies, cap. $67 .{ }^{23}$ In the edict, the material ecclesiastical goods are presented under a spiritual veneer. Hincmar uses the edict and the capitulary in order to prove that the secular authorities have committed an offence. The passage says:

And both the ancient as well as the modern kings of the Franks who take the religion of these emperors as a model, have been accustomed to granting privileges to the 'churches' and servants of God; while those who do not preserve them accumulate their sins from their alms. Thus, since we speak of other memorable emperors and kings, the memory of your grandfather, of the great emperor Charles, should not be passed over. From him, as is usual, [the religion] was snatched away by the tongues of flatterers, so that he made a certain prejudgment about his 'church' property; since the bishops disapproved, and especially Patriarch Paulinus, as I understand that it is well known to you, he has thus reminded himself, and has contented both the 'church' and the bishops; since the prompt oral confession has not satisfied him, he has transmitted for those descendants who will emerge from his lineage a writing of his confession and confirmation signed with his own hand. 
A part of this edict is retained in your book, which is called the book of the imperial Capitularies, cap. 67 where it is written: "Since we know that next to the tradition of the holy Fathers the affair of the 'church' is the religious engagement of the faithful, the punishment of sinners, and the patrimony of the poor: we wish for everyone not only to preserve the possessions, but also to collect many things with God's help: nevertheless, in order that we could entirely eliminate from the ecclesiastics the mistrust of him previously held about the goods that are not to be divided, we have established that no division or diminution at all may be allowed either in our times, or in those of our sons; or, so long as God is dispensing, in those of our successors, who will have wanted to imitate either our will of the progenitors, or their example."24

The text suggests that Charlemagne was led to an offence against the 'church' by certain people at the court - so-called adulantium linguis ("tongues of flatterers"). The result, Hincmar writes, was that Charlemagne was robbed of his religion. However, the meaning of this statement remains vague. Hincmar uses the word subrepta ("snatched away") with reference to religio ("religion") but does not tell us anything about any further consequences of Charlemagne's loss of "religion." The offence itself is termed praeiudicium de rebus ecclesiis ("prejudgment about the "church' property"). The text says nothing about the exact nature of this crime. However - in view of Hincmar's outrage - it has to be assumed that a property crime was committed by Charlemagne. He must have taken away property from the 'church'. In any case, Paulinus introduced countermeasures by persuading Charlemagne to record the ownership rights of the 'church'. Charlemagne subsequently confirms in writing that; firstly, ecclesiasticae res non sunt dividendae ("“church' property is not to be divided"), and secondly, any iactura ("diminution") will not be tolerated. ${ }^{25}$ It is striking that in the quoted extract, it is Charlemagne's Christian moral behaviour that is criticised. Heading down the path of aberration, he needed moral guidance from a cleric (i.e. Patriarch Paulinus). It was his instruction which allowed Charlemagne to save face. Hincmar wants to make the point that even Emperor Charlemagne had the need for ecclesiastical guidance, since his morals were not immaculate. Arguing in this manner, Hincmar hopes to encourage Charles the Bald to follow his instructions. Portraying all his predecessors as morally perfect would not have inspired Charles the Bald. ${ }^{26}$ At this point, Alcuin's Epist. 139 to Paulinus II of Aquileia should be used for comparison. In Epist. 139, Paulinus features as a fighter against heresy and a champion for the correct Christian doctrine. The text contains an extraordinary link between Charlemagne as an Old Testament king and the civitas Dei. Paulinus appears as the guardian of the doors of the civitas Dei as well as the holder of the clavis Daviticae potentiae ("key of David's power"), which conveys Alcuin's admiration and respect for the patriarch. In the conclusion of Epist. 139, the Carolingian 'state' is pictured as the perfect Christian community of the civitas Dei on earth, led by Charlemagne, who is cast first as King David, then as King Solomon, and is defended from ungodly attackers from the outside (the heretics) by Paulinus. In this situation, Charlemagne, under the pseudonym of an Old Testament king, 
certainly seems in need of ecclesiastical support - only, however, against irreligious assaults from the outside. The difference between the two representations of Charlemagne and Paulinus II of Aquileia is that in Alcuin's Epist. 139, the ecclesiastical support is not the consequence of any misconduct on the part of the ruler; Charlemagne is portrayed as being innocent and completely in the hands of the non-Christian enemies. ${ }^{27}$ In Hincmar's Quaterniones, however, the ecclesiastical support is mandatory for the restoration of the honour of Charlemagne, who has committed an offence. ${ }^{28}$

Only a few lines after Hincmar's criticism of Emperor Charlemagne, who appears as an intermediary between the Carolingian and the Christian Roman emperors, King David features as a sinner. Hincmar alludes to 2 Sam 11:1-12:25, where David conceitedly claims Bathsheba, the wife of Uriah the Hittite, impregnates her and finally gets Uriah - one of his most loyal soldiers - killed in battle, in order to marry Bathsheba. As a consequence, David is reprimanded by the prophet Nathan, who is sent by God and proclaims a punishment for his sins of adultery and murder; David and Bathsheba's son is doomed to die. Even though David turns all his pride into humility and repents by praying, fasting and sleeping on the ground during his son's illness, the child dies. David is reconciled with God, and his second son, Solomon, is again loved. Hincmar comments as follows on this scriptural passage:

What is lawful is not depicted, as it often tends to happen, in the eyes of men, but is nonetheless always depicted in the eyes of the Lord. But just as David who is to be extolled: Since the beginning of every sin is pride, acting against his avowal, which has been avowed, saying: The Lord lives, since I will frolic before God, and I will be humble in my own eyes the grace of the prophecy and the royal dignity, which he has lost by sinning, he has regained by repenting as a confessor before the eyes of Nathan. ${ }^{29}$

By using the image of the Biblical king who has offended against God, Hincmar, who is clearly casting himself as Nathan here, has two messages for Charles the Bald: firstly, that if a person acts in a manner considered lawful by men, it does not necessarily mean that it is also considered lawful by God. In the eyes of men, Charles the Bald and his direct officials have acted within the law; in the eyes of God, they have sinned, since superbia ("pride") is the sin itself. Secondly, David has repented of his sins and thus regained the favour of God. In other words, it is always possible for a person to correct what he has done wrong and restore his honour before God.

Subsequently, Hincmar lists all the promises Charles the Bald has already made to the 'church' at previous synods before the Frankish bishops (present and not present in person). ${ }^{30}$ Twice the concept of misericordia occurs in Charles the Bald's own sequence confirmed and signed with his own hand at the palace in Quierzy. ${ }^{31}$ Afterwards, Hincmar reproduces some written statements made by popes ${ }^{32}$ and then refers particularly to the Antiocheni canones and the Gangrenses canones, emphasising that the canons are directly inspired by the 
Holy Spirit. ${ }^{33}$ The words Hincmar quotes from the Antiocheni canones are exigent and unambiguous:

But also the canons of Antioch instruct accordingly thus: "What belongs to the 'church' may be preserved under all solicitude and good conscience, as well as faith which is in God, who considers and judges everything: these things are also to be distributed by the judgment and power of the pontifex, to whom the people has been committed, and the souls who are assembled within the "church"." And likewise: "The bishop should have the power over the ecclesiastical property for distribution to all those who are in need, with the highest reverence and fear of God. May also he himself partake in the things he needs, inasmuch as he still needs, for both his necessary future uses and those of the brethren who are received by him." 34

The selected passage not only demands that the ecclesiastical goods be regarded as inviolable and that the bishop has the power of disposition, but also considers it important to highlight the bishop's personal claim to a share in these possessions, beyond the mere financing of his clerics. Hincmar then returns a second time to the Christian Roman emperors in the context of proving that it is unlawful to summon a bishop before a secular court. Hincmar presents a law from the sixteenth book of the Codex Theodosianus, which is afterwards sanctioned by Constantine III. ${ }^{35}$ Theodosius I occurs as christianissimus imperator together with Ambrose, who is called humillimus. ${ }^{36}$ Other Christian Roman emperors (Valens, Gratian, Valentinian etc.) are mentioned in support of the aforementioned argument. ${ }^{37}$

Thereupon, Hincmar states the fact that all the property owned by the 'church' has been guaranteed by secular authorities. ${ }^{38}$ Hincmar corroborates this statement by quoting from Augustine's Sermo VI. Ioannis Evangelii. ${ }^{39}$ Ius humane is the "human law." The main point Hincmar wants to make is that people own property as a result of the law made by the ruler. Whoever claims ownership has possessions solely by royal law. Hincmar uses Augustine in order to emphasise the following: the rulers are always legally involved as far as 'church' property is concerned. 'Church' property has to be guaranteed by the law of the secular leader. Only via the mediation of the 'state' can the 'church' own property. The 'church' cannot own property on its own authority. 'Church' property is sanctioned by royal decree. As far as ecclesiastical property guaranteed by a royal decree is concerned, this guarantee cannot easily be revoked or declared invalid by a ruler.

What has been decided by previous emperors must be observed. Again, laws enacted by the Christian Roman emperors Honorius and Theodosius II are mentioned; any clerics who are accused before a bishop must be confirmed by witnesses, and the bishop himself needs to hear the case. This is so that as many people as possible will learn about the case if the accused clerics prove to be innocent.

Drawing on Augustine's Sermo VII. Ioannis Evangelii, Hincmar considers it to be a matter of secular law that anyone who has lied in any claims should not profit from what he has affected. This applies to people in general. Since any 
person may err, an emperor too may err, when taking up someone's entreaties. Likewise, if the 'state' has promised to grant a request made by the 'church' under false pretences, the 'state' is not obliged to follow it through. By referring to Augustine, Hincmar wants to show that it is a matter of secular law that anyone who has lied when making any claims should not benefit from what he has achieved through lies. In other words, Hincmar wants to say that Charles the Bald has erred and made a rash judgment, which he now needs to revise. Furthermore, Hincmar argues that a cautious (cautus) Christian (sanctus) king investigates a case diligently before making a judgment. ${ }^{40} \mathrm{He}$ adds that if the bishop (in this case Bishop Hincmar of Laon), when accused, will not accept the judgment of those he has elected or of those bishops esteemed by his metropolitan or the judgments of the synodal canons, then there will always be the judgment decreed by the sacred canons, which he has to uphold. Conversely, if the man of the king's military (in this case the son of a homo militaris named Liudon), when accused, refuses to obey to the royal missi and the secular laws, there will always be the legally binding judgment of the capitularies. Here, Hincmar makes it clear to Charles the Bald that canon law (as part of the ecclesiastical law) is to be applied to clerics, while capitularies (as part of the secular law) are to be applied to laymen.

Afterwards, mentioning Gregory the Great, Hincmar asserts:

"From there, a legal sentence - which the Blessed Gregory, just as his predecessors did, decreed to be canonical in a monitory letter given to John says: 'It is necessary that what has been done against the laws does not have strength."'41

Then, quoting from Augustine's De vera religione, Hincmar writes:

"Although in the matter of these temporal laws men judge over them when they establish them, nevertheless, once they have been established and confirmed, it will not be fitting for a judge to judge over them, but rather according to them. Notwithstanding, a legislator of temporal laws, if he is a good and wise man, should consult that eternal law, over which no soul is allowed to judge, so that he may discern according to its unchangeable rules what is to be ordered and prohibited at the moment. Thus, it is lawful that the worldly souls know the eternal law, but unlawful that they judge it."42

Supported by Augustine, Hincmar says the following to Charles the Bald; firstly, in secular law, although fallible humans judge over it when they enact it, a judge is not allowed to give a verdict on it, but is merely allowed to decide on the basis of it. Secondly, secular law, once made and confirmed by men, cannot easily be repealed. Thirdly, at most, a judge can say that a law tends to have a particular meaning and then make adjustments accordingly. Finally, there are eternal laws which a judge must never neglect in his decision-making. Hincmar wants to draw the king's attention to the fact that in the present case a fundamental Christian rule laid down in the Holy Scriptures has been violated, namely the 
tenth commandment of the Decalogue: "Thou shalt not covet." After a quote from Prosper, ${ }^{43}$ Hincmar continues as follows:

For if the Roman emperors declared their law to be eternal or perpetual, then the law which has been promulgated by the Holy Spirit is so much more eternal. Speaking about the distinction that has been shown in it, S. Leo ${ }^{44}$ says: "Whatever may have been either doubtful, or obscure, in them, we have known that this is to be followed, which is found neither to be contrary to the evangelical precepts, nor against the decrees of the saints." 45

Eventually, by first making reference to the Books of Kings, ${ }^{46}$ Hincmar returns to the Christian Roman emperors, in order to make his final principal statement. The passage reads as follows:

And in the sacred history of Kings it is written: If a man has sinned against a man, the Lord can be reconciled with him; but if a man has sinned against the Lord, who will pray for him? Remember the memorable deeds of Theodosius, and of the memorable man Ambrose, and because Theodosius transgressed like a man, Ambrose reprimanded him like a true priest, and Theodosius patiently and humbly received divine correction through him. And thus he has been exalted, by his merit as well as by his name, and by his honour of sanctity above all Roman emperors after Constantine. Happy is that emperor, who has had during his time the kind of priest who has managed to impose on him a worthy apology for the aberration, and to confirm a law that if any leader, in an angry state of mind, decided to claim against anyone too severely, the ministers of the 'state' dare not enforce that same law before thirty days, until the mind has cooled; and looking inwards, he would see what is true, and would decide what is lawful to do. For anger hinders the man so that he cannot discern truth, because, as a certain wise man has said, angry thoughts are the vipers of a generation: for they first eat the mind, their mother. And the Apostle: The anger of a man, he says, does not devote itself to the justice of God. And happy is Ambrose, the priest of God, who lived during the time of such an emperor. For it is written: Blessed the one who preaches justice to the attentive ear. Happy are indeed both, the priest as well as the emperor. For lest the anger of God come down upon the emperor for his aberration, he had during his time a priest, about whom the Lord has not complained $[\ldots]^{47}$

In this passage, Hincmar affirms that thanks to the bishop the emperor rectified his excessive punishment of the Thessalonians and then repented humbly of his $\sin$. He even enacted a law stating that when an enraged emperor imposes penalties, a period of thirty days has to be observed to see whether the emperor will decide otherwise when in a less agitated state. Although there is no direct evidence of Augustinian ${ }^{48}$ influence, as for instance in Alcuin's Epist. 139, where Charlemagne's realm is explicitly referred to as the civitas Dei, there is clear 
evidence of indirect Augustinian influence at both levels: the level of content and the formal level of Hincmar's text. At the level of content, the Roman emperors Constantine I and Theodosius I appear as extraordinary Christian rulers. Hincmar maintains that Theodosius I has been exalted above all Roman emperors other than Constantine I. In the De civitate Dei, Augustine dedicates two separate chapters (25 and 26 of Book V) to these Christian emperors. Hincmar expands on the incident when Ambrose and other bishops convinced Theodosius I to repent of his action of punishing the Thessalonians too harshly. This incident features in Book V of the De civitate Dei, in the chapter devoted to Theodosius I (26), where the emperor is held in very high regard for his humility and repentance. It becomes evident that Archbishop Hincmar, who is writing to King Charles, draws parallels between himself and Bishop Ambrose, and between King Charles and Emperor Theodosius $\mathrm{I}^{49}$ In a cunning and very self-assured manner, Hincmar criticises Charles the Bald for his prejudgment and rash decision to punish Bishop Hincmar of Laon in an unprecedented way and asks him to repent and correct his deed. At the formal level of the text, one can see that Hincmar adopts Augustine's use of felix and beatus by applying these terms to Emperor Theodosius I and Bishop Ambrose, who serve to represent King Charles and Archbishop Hincmar himself. Furthermore, one can find the concept of humilis/humilitas, which emerges as a key attribute of Christian rulers in the De civitate Dei, and as a particular virtue of Theodosius I. As far as Hincmar's repeated associations of Carolingian rule with the Roman imperial tradition are concerned, it is worth taking a final glance at Alcuin's Epistolae and considering Epist. 246, a letter which Alcuin sent to Archbishop Theodulf of Orléans in 801/802, following Charlemagne's imperial coronation. In the epistle, Alcuin similarly promotes a Roman law to Charlemagne in the context of a legal dispute - a dispute in Tours, which involved Alcuin, Charlemagne, Theodulf of Orléans and the community. Likewise, Alcuin, then the abbot of the monastery of Saint-Martin, writes in defence of his territory, the Basilica of Saint-Martin de Tours, and the associated community. The Roman law in question concerns the right of sanctuary in sacred places and was effective under Christian Roman emperors such as Honorius. Epist. 246 is exceptional because it integrates Charlemagne into the Roman imperial tradition. Alcuin's motive for referring to the Roman emperors in Epist. 246 corresponds to that of Hincmar in the Quaterniones; the linking of Charlemagne with the Roman imperial tradition is a strategy to put the Carolingian ruler under an obligation to acknowledge and uphold a particular law that was in force during the Roman imperial period. However, the nature of the connection between the Carolingian rulers and the Roman emperors, as well as the representations of both the Carolingian rulers and the Roman emperors, are different in the Quaterniones and in Epist. 246; while Hincmar admits that "[Theodosius I] has been exalted, by his merit as well as by his name, and by his honour of sanctity above all Roman emperors after Constantine, ${ }^{50}$ he is not explicit about the position of Charles the Bald in relation to these emperors. Since Hincmar parallels himself with Ambrose and parallels Charles the Bald with Theodosius I, it must be assumed that he views the two secular authorities as equals. They both have committed a violation of the 
law and now receive correction through the two religious authorities. Hincmar stresses Charles the Bald's likeness to Theodosius I in order to have him follow the legal advice he wants him to follow, which is rooted in the Roman legal tradition. In Epist. 246, however, Alcuin's explanation as to why it is indispensable for Charlemagne to endorse the law regarding the right of sanctuary in 'churches' is that "it is imperative that neither the dignity of the 'church', nor fear and reverence for it, should be smaller in the most excellent regnum and most powerful imperium." Rather, Alcuin says, they should continually grow for the praise and glory of Jesus Christ who honoured Charlemagne above all other kings and emperors with the beauty of sapientia and exalted him with the potentia regni. Although Alcuin relates Charlemagne to the Roman emperors with the aim of promoting this specific Roman law, he emphasises Charlemagne's superiority as a Christian emperor over all his exemplary antecessores, in order to have him follow said law.

The findings from comparing these passages where Augustine, Hincmar and Alcuin reflect on worldly rule therefore are that not only Alcuin but also Hincmar makes use of Augustine's De civitate Dei, both directly and indirectly at the level of content and at the formal level of the text. However, Hincmar is much more critical of worldly rule than Alcuin. As we have seen, by equalling the Carolingian rulers with the Roman emperors, Hincmar integrates Charlemagne and Charles the Bald smoothly into the Roman imperial tradition and contends together with examples of Old Testament kings that all these leaders did not have perfect moral integrity. Consequently, they all ultimately needed Christian guidelines and help (in the case of Charles the Bald the bishops' guidelines and help) for moral improvement. Alcuin, on the other hand, as several of his epistles clearly express, places Charlemagne above all other exemplary worldly rulers - including emperors Constantine I and Theodosius I - and claims that he was the only one to have secular power capable of fulfilling Augustine's condition of the implementation of God's true iustitia ("justice"), which is the sole precondition for a civitas Dei.

In each of the two last paragraphs of the Quaterniones, there is one direct reference to Augustine. In the penultimate paragraph,${ }^{51} \mathrm{Hincmar}$ makes one final attempt to explicate for Charles the Bald both the legal and the moral facets of the situation. He starts by elucidating the legal aspect. Hincmar quotes the beginning of a verse from St. Paul's 1 Corinthians ${ }^{52}$ (which originally refers to Israel as an example of a people who have sinned), in order to introduce another example of an Old Testament king (Uzziah) ${ }^{53}$ whose pride and sins against God were the cause of his downfall. By using a verse from the Gospel of Matthew, ${ }^{54}$ Hincmar declares that Uzziah's punishment is in accordance with those through whom the Holy Spirit speaks and through whom the ecclesiastical canons are promulgated. He says that whoever voluntarily and with deliberation violates and overthrows the constituta divina ("divine constitutions") is separated from the body of the 'church' and, unless he is reincorporated into the 'church' through penitence, will also be separated from the eternal 'church'. By drawing on a verse in St. Paul's 1 Corinthians, ${ }^{55}$ he adds that one should not even share a meal with the sort of person who pretends to be Christian but does not act accordingly. Moreover, Hincmar 
quotes from a verse spoken by St. Peter in the Acts of the Apostles ${ }^{56}$ with the aim of highlighting that because God does not consider the person but only whether someone fears Him and acts in a morally correct manner, everyone is equal before the law, including Charles the Bald. Hincmar then moves on to the moral facet of the case. He links the legal with the moral aspect by drawing on St. Paul's Ephesians. ${ }^{57} \mathrm{He}$ quotes the beginning of a verse that advises Christians not to partake in the fruitless deeds of darkness. The verse continues by saying that the misdeeds rather need to be exposed. Augustine tried to explain this verse (particularly the meaning of "exposing the misdeeds"), and Hincmar therefore turns to him and his exegesis. According to Augustine, there are two ways in which the evil does not stain you: firstly, in not consenting, and secondly, in actively contradicting. The first one means not communicating by not agreeing with the evil. The second one means disproving the evil. What Augustine says afterwards is concerned with the criticism of other people's sins and errors. He says that if one corrects others, one must be careful not to do it too proudly and high-handedly. The penultimate paragraph reads:

In this matter, since, just as the Scriptures say: although these things happened to them as an example, they have been written for our sake, it should be carefully noted that, as long as Uzziah worshipped the Lord, he held the realm peacefully and gained repeated victories against neighbouring and foreign races. But afterwards he did not take first his ceremonial service, and instead in his priestly office raised a presumptuous hand against divine law, and so until the day of his death he has remained cut off in his house, full of leprosy, and he has gained no victory: not even able to abide anymore with those others who waged the wars of the Lord for the enemies of Israel, that had held the image of the 'church', covered with leprosy he is, that is, beaten and ruined by grave sin. Because of this, and because of the judgment of those about whom the Lord says: It is not you who speak, but rather the Spirit of your Father who speaks within you, and through whom, by means of the same Spirit, the sacred canons have been promulgated; because of this, since Peter teaches, God is not an accepter of assumed characters, whoever is voluntarily and with intention violating and overthrowing the divine constitutions is separated from the body of the 'church', and unless he is reincorporated into that same 'church' through penitence and through the reconciliation of priestly benevolence, he will be separated also from the eternal 'church'. After that, the Apostle also advises, With such a person do not even share a meal. And in the same way, as Christ speaks within him, he cautions everyone, saying: Do not partake in the fruitless deeds of darkness. Explaining this sentence, the blessed Augustine says: "There are two ways in which the evil does not stain you: if you do not agree, and if you contradict; this is, not to communicate, and not to agree. It is indeed communicated, when a fellowship of will or approbation is attached to his deed. Accordingly, the Apostle cautions us, saying: Do not partake in the fruitless deeds of darkness. And since it was not enough simply to not agree, if negligence of the 
principle then followed, rather, he says, you must go further and also contradict. Observe how he includes each one: do not partake: do not agree, do not praise, do not approve. But what is this, then, go further and contradict? Reprehend, attack, correct. Then in the reprehension itself or in the correction of the sins of others, care should be taken that he who corrects another should not extol himself; and whoever thinks that he stands tall should make sure that he does not fall; in public the rebuke should resound fearsomely, internally the love of gentleness should be retained. In this way you should neither be consent to the evil, so that you approve it; nor should you neglect it, so that you do not contradict it; nor should you be haughty, so that you contradict rudely." 58

In summary, Hincmar's legal reasoning in the above passage is primarily supported by Old Testament examples of people who lost God's favour by sin and by reference to the ecclesiastical canons which are inspired by the Holy Spirit. Morally, however, Hincmar uses Augustine as the highest instance.

In the last paragraph, ${ }^{59}$ Hincmar focuses entirely on himself and his request to the king. He gives an explanation of his motive for sending this text to Charles the Bald. Furthermore, he feels a great urge to defend his position and justify why he has backed the 'church' and his nephew so vigorously with every available resource. He is assiduous in eliminating right away the three most plausible - and selfish - motives for defending Bishop Hincmar of Laon: a carnal fondness of kinship, and self-defence as well as self-interest - insofar as charges against a bishop from the province of Rheims are at the same time an insult to Hincmar himself as archbishop of Rheims. Instead, Hincmar introduces the true incentives for composing this text. Firstly, he mentions the zelus ("zeal") promoted in the Psalms (and in the Gospel), where it says: "The zeal for your house consumes me." What is meant here is the "zeal" for the universal 'church', which is the house of God, as well as for the sacred priestly order, to which that of the bishop belongs. By referring to the Second Book of the Maccabees, where people are praised who lost their lives in their fight for Christianity, he reconfirms the urgency to defend the 'church'. ${ }^{61}$ In other words, Hincmar, in his defence of ecclesiastical privileges, places himself on an equal footing with martyrs. Secondly, Hincmar speaks of his "zeal" for the welfare and prosperity of Charles the Bald himself. Here he introduces the theme of veritas ("truth") in his address to the king. What he writes would be repeated in terms of content, language and references in the praefatio of the De regis persona et regio ministerio a few years later (ca. 873). Hincmar asks the king to weigh modestly any words that may resound too sharply, since they are in fact friendly because their intent is well-meaning, whereas the blandishments from a flatterer are actually unfriendly. He supports this statement with a quotation from the Book of Proverbs, saying that the wounds of a friend are better than the kisses of a loathing enemy. ${ }^{62}$ Concerning the theme of veritas ("truth"), Hincmar reproduces the well-known sentence from Terence that complaisance begets friends, truth hatred. Then he recites the verse "you shall know the truth, and the truth shall make you free" ${ }^{\prime 3}$ from the Gospel of John. The final words of 
the Quaterniones include an explicit reference to Augustine and are in line with Hincmar's affirmed concern to provide Charles the Bald with a truthful and wellintentioned judgment. Hincmar insists that what Augustine says should stick in the king's mind: that it is the way of a deceitful or inexperienced physician to put a plaster on a wound in a manner that it either does harm or does not help. What Hincmar intends to say is that he himself is firstly honest and secondly experienced, and therefore, according to Augustine, his sincere and wise judgment must be taken into account. Hincmar therefore concludes that everything written above, which truth itself has brought forth through the mouths of truth-tellers without adulation and for the king's own welfare, shall not displease Charles the Bald. The last paragraph is as follows:

And do not think, dearest and most benign lord, that I have been provoked to write these things either because of some carnal fondness of kinship, or because those things have been done so outrageously against a bishop of Rheims, my own entrusted province; rather I write because of a zeal, which has been written about both in the psalm and in the Gospel: The zeal for your house consumes me, the zeal, clearly, is for the universal 'church', which is the house of God, and for the sacred priestly order, in which that of the bishop is one among all, and for the office of my littleness, reading that, because of the father's laws, God's elected even longed for the death of the body, and that the Catholic 'church' sings of him in divine praises as a saint: He who has fought for the law of his God even until death. It is no less a zeal for your welfare and prosperity, which we hope for, that I have written these things. Finally, I ask that you mark more carefully in this [letter] the obedience of my service, since, if anything at any point resounds rather sharply, this is not what is meant by my words: although they may pierce, your gentleness ought to weigh them temperately, since a flatterer is a seductive enemy. Which is indeed what the Scriptures say: Because the wounds of a friend are better than the kisses of a loathing enemy. Nor indeed does that well known sentence lay siege to your mind, although it holds captive the mind of some, which says: complaisance, that is, flattery, clearly adulation, begets friends, truth hatred: because, just as you love the truth as a friend of the truth, you know that it is said about the Truth: You shall know the truth, and the truth shall make you free. Therefore, what the blessed Augustine says should stick in your mind, because it is the way of a deceitful or inexperienced physician to put a plaster on a wound so that it either does harm or does not help. And the things written above, which truth itself has brought forth through the mouths of truth-tellers without adulation for your welfare, shall not displease you. ${ }^{64}$

The last paragraph, in particular, shows how self-assured Hincmar is in his argument. Augustine appears again as the highest moral instance; the Quaterniones end with a direct reference to him. Nevertheless, the content reveals that Hincmar in all likelihood mainly availed himself of Augustine's phrase because it seemed appropriate and suited the context. From this, it can be concluded that, clearly in 
the Quaterniones, unlike in the De regis persona et regio ministerio, Augustine was not an authority to be used for answering the legal questions at hand. In the Quaterniones, other material builds the corpus for the legal argument. Hincmar uses both ecclesiastical and secular texts as legal sources: from the Scriptures passages from the Old Testament with examples of kings prevail; papal decretals and, above all, the canons are also part of the ecclesiastical legal source material. Edicts issued by previous rulers as well as Carolingian capitularies make up the body of the secular source material. Augustine does not directly feature in the discussion concerned with the secular claims on ecclesiastical property. However, towards the end of the Quaterniones, Augustine emerges as an unchallenged religious authority and serves as proof that Hincmar's reasoning is not only legally correct but also morally sound and in line with the Christian code of conduct. In this respect, Augustine is used both for the moral instruction of Charles the Bald as well as for the justification of Hincmar's own opinion. Unlike Alcuin, Hincmar did not pose questions related to the Augustinian concept of an ideal civitas Dei. His awareness was built on the understanding that any Christian 'state' is in the spirit of God as long as it fulfils its obligations vis-à-vis the 'church': namely, that iustitia ("iustitia") is institutionalised and pax ("peace") is established. Hincmar was not a very original thinker in a theological sense, even though from a legal perspective his approach to the prejudgment made by the royal court (i.e. Charles the Bald) was ingenious. In the Quaterniones, Augustine was first and foremost a quotable moral authority.

\section{Hincmar's De regis persona et regio ministerio}

Hincmar's De regis persona et regio ministerio is a 'mirror for princes' ${ }^{65}$ written for King Charles the Bald. Unfortunately, we do not have a manuscript tradition of this text. ${ }^{66}$ However, it is an especially interesting work as far as both the explicit and implicit influences of Augustine are concerned.

The historical scholarship ${ }^{67}$ tends to agree with Schrörs ${ }^{68}$ that the work must have been composed around 873 . Already Schrörs holds that the time of writing cannot be determined with certainty. Together with Noorden, he assumes 873 to be the year of composition. In 873, Prince Carloman (in spite of an earlier pardon) raised the weapons against his father Charles the Bald for a second time and in consequence was sentenced to death. However, the sentence was finally mitigated to blinding. ${ }^{69}$ In line with E. Dümmler and Noorden, Schrörs finds that several passages in the De regis persona et regio ministerio may allude to this incident. ${ }^{70}$ His argument is plausible, since the following chapters may be indirectly or directly linked with the event: CAP. XVII., XVIII., XXV. and XXVII. on the importance of laws and their observance in general; CAP. XXIII., XXIV. and XXVI. on the legitimacy of violence such as killing and capital punishment on the ruler's authorisation; CAP. XIX., XX., XXVIII., XXXI. and XXXIII. on instances when forbearance and forgiveness are appropriate; CAP. XXIX. and $\mathrm{XXX}$. on the particular case of judging relatives. However, Augustine hardly features in the last two groups of chapters, which may be more directly associated 
with the case of Carloman as a relative of the king who has already been pardoned once. Instead, Augustine is more prominent in the first two groups of chapters, which are concerned with the very fundamental legal questions of the ruler's and the people's obligations with regard to the implementation and observance of iustitia ("justice") and of the legitimacy of violence (including killing and death penalty).

Devisse admits that a substantial part of the content seems to relate to Carloman's revolt. However, he does not deny that other circumstances may have led to the writing of the De regis persona et regio ministerio. He contends that, for the same reasons, one might also consider the years 868-871, when Charles the Bald experienced increasing difficulties with his son, or the winter of 858-859 (since Hincmar seeks to rouse the king's belligerent spirit). But according to Devisse, the evidence to abandon the date proposed by Schrörs (873) does not seem sufficient for him to establish an alternative hypothesis. ${ }^{71}$ Elsewhere, Devisse infers that in the De regis persona et regio ministerio, Hincmar - perhaps in memory of the consequences of too much indulgence on the part of Louis the Pious - tries to discourage cowardice (which would include, for instance, forgiving relatives) to Charles the Bald. The relatives of the king cannot escape the general rule. The king must always be exemplary; God did not spare his son. ${ }^{72}$ The reasons for the composition of the treatise are thus open to speculation. However, Devisse raises some other points worthy of note with regard to the key function of this text. He argues that it sheds light on Hincmar's attitude towards all the affairs on which he formerly had to judge or advise. These cases, which will be further explored here, include the conflict about the clerics ordained by Hincmar's predecessor Ebbo of Rheims, the controversy with Gottschalk, the divorce of King Lothar II, as well as the steps taken by the Bishop of Soissons against a priest. ${ }^{73}$

Before Hincmar received the archdiocese of Rheims from Charles the Bald in 845, Archbishop Ebbo of Rheims had been dismissed from office at the Synod of Thionville (835) on the grounds of disloyalty to Louis the Pious. He had transferred to the party of Lothar I, who had rebelled against his father Louis the Pious in 830 and 833 (together with his brothers Louis the German and Pepin I of Aquitaine).$^{74}$ After the death of Louis the Pious in 840 , Lothar I succeeded to the throne, and Ebbo was temporarily restored to office. ${ }^{75}$ But he was deposed again in 844, and Hincmar was appointed to the see. Since Hincmar regarded Ebbo's acts from the period of reinstatement (for the most part the ordination of certain clerics) to be legally invalid, he saw to it that these acts were abrogated at the Council of Soissons (853).$^{76}$ Hincmar's stand in this affair is very clear; firstly, it is right that a man holding an office loses his position irrevocably if he breaks his oath of fidelity to his superior. Secondly, any actions performed by a morally corrupt office-holder are invalid. ${ }^{77}$ Both judgments are further elaborated and placed in a wider context in the De regis persona et regio ministerio. They find expression in the following chapters: CAP. XXVII. "That laws from a just leader are to be officially acknowledged by anyone" and CAP. XXXI. "Whether one should exercise forbearance with regard to the biggest and official crimes." 
By presenting his doctrine of "double predestination" texts at the Synod of Mainz (848), where he countered his former abbot Rabanus Maurus (Archbishop of Mainz), Gottschalk started a debate in which Hincmar became involved. ${ }^{79}$ Gottschalk was found guilty of heresy, mistreated and transferred to the archbishop of Rheims. His case was discussed at the following councils: Quierzy (853), Valence (855) and Savonnières (859). In the meantime, unwilling to renounce, he had been permanently excommunicated and incarcerated in the monastery of Hautvillers. Although Pope Nicholas I then took on Gottschalk's case, the matter was never properly settled. When Gottschalk was ill and dying, Hincmar visited him but refused to give him the sacraments and had him buried without a Christian burial. This clearly shows that Hincmar himself had been exposed to the difficulty of establishing justice while demonstrating the right measure of forbearance (treated in CAP. XVIII., XIX., XX., XXVIII. and XXXI.) before writing the De regis persona et regio ministerio.

In 860, Hincmar took part in the dispute that arose about the separation of King Lothar II from his first wife. Since Lothar II had remained childless after his marriage to Teutberga, daughter of Boso the Elder, in 855, he wanted to separate from her with the intention of marrying his mistress Waldrada (with whom he already had an illegitimate son, Hugh). ${ }^{80}$ At Aachen, councils were convened several times (in January and February 860 and in April 862) to deal with the question of the separation. ${ }^{81}$ There were initially two parties involved in the dispute: the party surrounding Louis the German, which was in support of Lothar's endeavours, and the one surrounding Charles the Bald, which opposed his efforts. ${ }^{82}$ Eventually, with the backing of Emperor Louis II of Italy (his brother), Lothar II received approval from the clergy to divorce Teutberga and marry Waldrada in $862 .{ }^{83}$ Hincmar, acting as an adviser to Charles the Bald, had criticised Lothar's plan to obtain an annulment of the marriage in his De divortio Lotharii regis et Theutbergae reginae, written between March and September/October $860 .{ }^{84}$ In this memorandum, Hincmar treats matters of procedural law and assesses the validity of ordeals, oaths of purgation as well as different forms of legal separation. At the same time, the separation of the king also prompts him to more specifically define the rights and duties of a ruler. These preliminary reflections undoubtedly formed part of the groundwork for the composition of the De regis persona et regio ministerio.

The conflict of authority with Rothad, Bishop of Soissons, after 860 may also have compelled Hincmar to contemplate further legal questions such as usurpation. ${ }^{85}$ Rothad was a suffragan to Hincmar. He had removed a priest from office, and the decision had been authorised by an episcopal council. Hincmar's claim was that a suffragan bishop did not have the legal right either to depose a priest or to summon a council. He therefore demanded the reinstitution of that priest. However, due to a lack of compliance, Rothad himself was dismissed by Hincmar at a synod in Soissons (cloisters of St. Crispin) in 861. Thereupon, in 864, Rothad travelled to Rome equipped with the newly forged Pseudo-Isidorian Decretals, which attaches great weight to the papal authority. As a consequence, he was reinstated in 865 on the authorisation of Pope Nicholas I. A note in the Annales Bertiniani, claiming that the pope had decided "non regulariter sed potentialiter," 
conveys that, according to Hincmar, his judgment was the result of a confusion of ecclesiastical power with ecclesiastical law. ${ }^{87}$

In a broader sense, Devisse maintains that in the De regis persona et regio ministerio, Hincmar essentially wants Charles the Bald to be extremely rigorous in the implementation of the law. This, according to Hincmar, is one of the foremost duties of the royal ministry. Furthermore, Hincmar arrives at the judgment that a reasonable balance must be achieved between iustitia and caritas. ${ }^{88}$

An examination of the preface of Hincmar's De regis persona et regio ministerio will provide more information about the motive for Hincmar's writing as well as the nature, content and general structure of the text. Furthermore, it will show what can be expected from this work in terms of explicit and implicit references to other authors and sources. Hincmar writes:

To the glorious master faithfully devoted and devotedly faithful.

Obeying the precept of the Lord who orders through the prophet, ask the priests about my law, it has pleased you to consult me about certain capitula. About this, since Truth per se says, He who speaks of himself, seeks personal glory, I have considered it appropriate not to respond to you in my own bare speech, but through what the Holy Spirit in the Holy Scriptures and the Catholic doctors says, and to briefly bring together for you into a whole certain fragrant little flowers - actually, like flowers from the full field, that is, the field of the Scriptures, to which the Lord has given His blessing. And knowing the pledge, What you will have spent over and above, I will give back to you on my return, I have added above and beyond the things which I have seen to be adequate for the kingly ministry committed to you by God, a sort of twinkling spark to the light of your knowledge. Because truly, just as Comicus says:

Complaisance begets friends, truth hatred,

and assent, that is to say adulation, should not please a leader and master of the earth; also, not in the least does it behove a priest to follow it; if you will have found anything that is rather sharply said in the sentences about the person of the king and the kingly ministry collected by me, I beg that you do not believe that they have been collected against you, but rather for you, since I either know that you are of such a kind out of benignity and goodness and act in the way the sentences themselves describe, or I wish that you should be of such a kind and act in this way. Moreover, the sentences of this little book are separated in a triform collection. Firstly, about the person of the king and the kingly ministry in the general cause of the 'state'. Then, about what should be the moderation in the implementation of forbearance, and about the punishment of special persons, who, if acting fatally, cannot be corrected otherwise than being ordered to be punished with earthly death, which is said to be contradicted by some. Thereupon that the king because of the kingly ministry should also not spare on account of any relations of kinship those acting criminally against God and the Holy 'church' as well as against the 'state' by carnal affection. ${ }^{89}$ 
The second sentence of the preface conveys that Charles the Bald has sought advice from Hincmar as a member of the clergy regarding certain capitula. ${ }^{90}$ Putting forward a hypothesis based on G. Laehr, Devisse seeks to determine these capitula further. ${ }^{91} \mathrm{He}$ indicates that Laehr has drawn attention to particularities in the structure and composition of Hincmar's work and has noticed a close relationship between some capitula contained in a Paris manuscript and the De regis persona et regio ministerio. On the whole, Devisse rejects both Laehr's proposition that these capitula constitute the preparatory draft of the De regis persona et regio ministerio, as well as the possibility that they were compiled in retrospect by a reader of Hincmar's treatise. However, he sums up the argument by saying: "Les parentés sont cependant telles qu'il faut bien admettre que, pour une large part mais pas pour la totalité du texte - ces capitula ont constitué l'armature du traité d'Hincmar." 92 Devisse asserts that there is clear evidence of Hincmar's use of these capitula; the patristic texts of the Paris manuscript are borrowed in the same fragmented and simplified form and with the same gaps in the text. He adds that evidence also exists of careful work on these texts consulted and commented on; references often unclear in the collection are almost always vetted for accuracy and clarification; additional texts are quoted or mentioned; awkward wording is not reused but rather the same ideas expressed differently. Nevertheless, Devisse points out that, once the references had been clarified, Hincmar was mostly content to weld the title contained in the table of titles of the collection to the patristic text quoted in the main body of the collection: thus, for instance, bringing together two capitula while neglecting others. Hincmar's work merely consisted of reprocessing and reclassifying the texts that had been sent to him. ${ }^{93}$

In the third sentence of the De regis persona et regio ministerio, Hincmar states that he will not use his own words when responding to Charles the Bald but will rather draw on the Scriptures and works of the Church Fathers. In the last sentence of the first part of the preface, he says that he will add to the necessary guidelines for 'state' leadership some additional information in order to make Charles the Bald stand out as an illustrious, knowledgeable ruler. Hincmar gives a justification for relying heavily on the Scriptures and canonical 'church' literature. He argues that people who express their own thoughts only aim at personal recognition. Furthermore, he maintains that the Holy Spirit speaks from these sacred texts that have been blessed by God. The exact reason for choosing this style of writing in this work cannot be established. Since Hincmar writes regarding the advice he provides that he "briefly brought it together into a whole," it may be that he did not have the time to treat the questions in a more detailed manner and expand on his own point of view. In light of what Hincmar says in the second part of the preface, however, it is also possible that he uses the Christian texts in order to legitimise his critical stance on the moral conduct of laymen and clergymen of any social rank. Hincmar then explains that his work is composed of three parts: the first part dealing with kingship as an office and the importance of morally correct governance (CAP. I-XVIII); the second part teaching moderation in the implementation of forbearance, the administration of the penal power and the imposition of the death penalty (CAP. XIX-XXVIII); the third part reminding 
the ruler not to spare his close ones on account of kinship if they acted criminally against God, the 'church' and the 'state' (CAP. XXIX-XXXIII).

With regard to the direct references to other authors and sources, it is noticeable that very long quotations permeate the De regis persona et regio ministerio. Compared to Alcuin, Hincmar's quotations are clearly longer, and an independent processing of the matter is not readily perceptible.

A more detailed examination of the structure of the De regis persona et regio ministerio will reveal, firstly, that of all the authors and sources cited and quoted, Augustine prevails, and, secondly, that of all of Augustine's works cited and quoted, the De civitate Dei prevails. Here is a table of the chapters and the authors treated in them (Table 7.1). ${ }^{94}$

It can be seen that the De regis persona et regio ministerio opens with Augustine and that he features eighteen times overall (i.e. in eighteen chapters), on eight of these occasions (i.e. in eight chapters) with reference to the De civitate Dei. Gregory the Great appears eight times; while we find Cyprian three times, Innocent three times, Ambrose twice, Jerome twice, Orosius once, Celestine once and John Chrysostom once. As far as the number of explicit references to Augustine in Hincmar's texts is concerned, it can be said that the De regis persona et regio ministerio is the work in which Augustine's De civitate Dei is most often quoted. Furthermore, it should be noted that in the De regis persona et regio ministerio, Hincmar - like Alcuin generally - refers exclusively (with one exception) to the first five books of the De civitate Dei: he quotes from Books I, IV, V and IX. When considering Hincmar's works as a whole, it seems that quotations from the first and the last books of the De civitate Dei are most frequent. However, as is shown in the analysis of Hincmar's epistolae (devoted to locating direct evidence of Augustine), it appears that Hincmar was not influenced by Augustine to the extent Alcuin was. Gregory the Great and Cyprian (and in other works Bishop Remigius of Rheims and Gelasius) are also prominent in Hincmar's writing.

What can be done in view of the fact that the De regis persona et regio ministerio is a compilation of quotations rather than an independent work is to try to consider the composition as a whole and to ask the following questions: how does Hincmar understand the ideas he borrows from other authors and sources? What place does Augustine take among them? What is the meaning of these old ideas in the new context? What is Hincmar's general statement? The subsequent analysis will focus on indirect evidence of Augustinian influence at both the level of content and the formal level of Hincmar's text. The political terms imperare/imperium and gentes/gentilitas; the expressions dilatare and subiugare; the concepts of pax, iustus/iustitia, felix/felicitas and felicitas aeterna, beatus/beatitudo, misericors/misericordia and humilis/humilitas, as well as the figures of the Old Testament kings David and Solomon will be considered (either independently or as part of certain fixed expressions). I will explore how some of these concepts - which have roots in both ancient Greek philosophy (Platonic, Aristotelian, Epicurean, Stoic) and the Old Testament and which were also absorbed in Christian thought before Augustine - are applied to social and 
Table 7.1 Authors treated in the De regis persona et regio ministerio by chapter

\begin{tabular}{|c|c|c|}
\hline Chapter & Title & Authors \\
\hline CAP. I. & "That God makes good kings, permits bad ones." & $\begin{array}{l}\text { Augustine; Gregory } \\
\text { the Great }\end{array}$ \\
\hline CAP. II. & $\begin{array}{l}\text { "That a good king means happiness to the } \\
\text { people, a bad king unhappiness." }\end{array}$ & Cyprian \\
\hline CAP. III. & $\begin{array}{l}\text { "Correct administration is the means of } \\
\text { great power." }\end{array}$ & Gregory the Great \\
\hline CAP. IV. & $\begin{array}{l}\text { "To what kind of advisers the king should } \\
\text { turn to." }\end{array}$ & Ambrose \\
\hline CAP. V. & $\begin{array}{l}\text { "Nothing is more favourable than if those who } \\
\text { are ruling have the skill of ruling." }\end{array}$ & $\begin{array}{l}\text { Augustine } \\
\qquad \text { (De civitate Dei) }\end{array}$ \\
\hline CAP. VI. & $\begin{array}{l}\text { "That it is useful that good kings reign } \\
\text { continually and far and wide." }\end{array}$ & $\begin{array}{l}\text { Augustine } \\
\quad \text { (De civitate Dei) }\end{array}$ \\
\hline CAP. VII. & $\begin{array}{l}\text { "Necessity alone impels that good kings wage } \\
\text { war and expand the realm." }\end{array}$ & $\begin{array}{l}\text { Augustine } \\
\qquad(\text { De civitate Dei) }\end{array}$ \\
\hline CAP. VIII. & $\begin{array}{l}\text { "The zeal of the king in the readiness for war, } \\
\text { and the exhortation to the soldiers." }\end{array}$ & Augustine \\
\hline CAP. IX. & $\begin{array}{l}\text { "That those who have waged war under the } \\
\text { authority of God did not sin." }\end{array}$ & $\begin{array}{l}\text { Augustine } \\
\qquad \text { (De civitate Dei) }\end{array}$ \\
\hline CAP. X. & $\begin{array}{l}\text { "That those who are at war, and serve under } \\
\text { arms, do not displease God." }\end{array}$ & Augustine; Jerome \\
\hline CAP. XI. & $\begin{array}{l}\text { "That a soldier, obeying a power, does not sin if } \\
\text { he kills a man." }\end{array}$ & $\begin{array}{l}\text { Augustine } \\
\qquad \text { (De civitate Dei) }\end{array}$ \\
\hline CAP. XII. & $\begin{array}{l}\text { "That victory in war is given by the Almighty to } \\
\text { whom he wants it to have." }\end{array}$ & $\begin{array}{l}\text { Augustine } \\
\qquad(\text { De civitate Dei) }\end{array}$ \\
\hline CAP. XIII. & $\begin{array}{l}\text { "That God stands by when war is waged, and } \\
\text { prepares the victory for the just party." }\end{array}$ & Augustine \\
\hline CAP. XIV. & $\begin{array}{l}\text { "That one must not despair of the small number } \\
\text { if the Lord is with the soldiers." }\end{array}$ & Orosius \\
\hline CAP. XV. & $\begin{array}{l}\text { "That one has to make offerings for those who } \\
\text { have died in war." }\end{array}$ & - \\
\hline CAP. XVI. & $\begin{array}{l}\text { "That kings serve the Lord of kings, also giving } \\
\text { laws for him." }\end{array}$ & Augustine \\
\hline CAP. XVII. & $\begin{array}{l}\text { "That it is also compelled to the observance } \\
\text { of justice." }\end{array}$ & $\begin{array}{l}\text { Augustine; Gregory } \\
\text { the Great }\end{array}$ \\
\hline CAP. XVIII. & $\begin{array}{l}\text { "That he serves Christ who reproves the wicked } \\
\text { by love of justice." }\end{array}$ & $\begin{array}{l}\text { Augustine } \\
\qquad \text { (De civitate Dei) }\end{array}$ \\
\hline CAP. XIX. & $\begin{array}{l}\text { "About the moderation in the implementation } \\
\text { of forbearance." }\end{array}$ & Ambrose \\
\hline CAP. XX. & $\begin{array}{l}\text { "Whom the leader or judge should rightly be } \\
\text { allowed to forgive." }\end{array}$ & $\begin{array}{l}\text { Gregory the Great; } \\
\text { Augustine }\end{array}$ \\
\hline CAP. XXI. & $\begin{array}{l}\text { "The leader should fear that he is deceived by } \\
\text { gifts or adulation of any criminal." }\end{array}$ & - \\
\hline CAP. XXII. & $\begin{array}{l}\text { "It is to be avoided by the leaders that they are } \\
\text { connected by friendships of criminals." }\end{array}$ & Gregory the Great \\
\hline CAP. XXIII. & $\begin{array}{l}\text { "That holy men have punished the accused with } \\
\text { death by law in order to inflict fear." }\end{array}$ & Augustine \\
\hline CAP. XXIV. & "That killing a man is not always criminal." & $\begin{array}{l}\text { Augustine } \\
\qquad \text { (De civitate Dei) }\end{array}$ \\
\hline
\end{tabular}


Table 7.1 Continued

\begin{tabular}{|c|c|c|}
\hline Chapter & Title & Authors \\
\hline CAP. XXV. & $\begin{array}{l}\text { "It is proper that the king is the corrector of } \\
\text { the unjust." }\end{array}$ & Cyprian \\
\hline CAP. XXVI. & $\begin{array}{l}\text { "That for the punishment of the guilty the sword } \\
\text { has been permitted to the leader by God." }\end{array}$ & Innocent \\
\hline CAP. XXVII. & $\begin{array}{l}\text { "That laws from a just leader are to be officially } \\
\text { acknowledged by anyone." }\end{array}$ & $\begin{array}{l}\text { Innocent; Cyprian; } \\
\text { Augustine }\end{array}$ \\
\hline CAP. XXVIII. & $\begin{array}{l}\text { "That to those who are to be punished for } \\
\text { their crimes forbearance is to be yielded } \\
\text { sometimes." }\end{array}$ & - \\
\hline CAP. XXIX. & $\begin{array}{l}\text { "That the king should not spare his relatives } \\
\text { acting in a corrupted manner by carnal } \\
\text { affection." }\end{array}$ & $\begin{array}{l}\text { Gregory the Great; } \\
\text { John Chrysostom; } \\
\text { Jerome }\end{array}$ \\
\hline CAP. XXX. & $\begin{array}{l}\text { "To what extent children and relatives, if they } \\
\text { have sinned, should be spared." }\end{array}$ & Gregory the Great \\
\hline CAP. XXXI. & $\begin{array}{l}\text { "Whether one should exercise forbearance with } \\
\text { regard to the biggest and official crimes." }\end{array}$ & $\begin{array}{l}\text { Celestine; Gregory the } \\
\text { Great; Augustine }\end{array}$ \\
\hline CAP. XXXII. & $\begin{array}{l}\text { "What is the rod of punishment of the good king, } \\
\text { and the manna of sweetness." }\end{array}$ & - \\
\hline CAP. XXXIII. & $\begin{array}{l}\text { "On account of the difficulty in the instance of a } \\
\text { plurality of the sinning the punishment to be } \\
\text { overlooked or postponed." }\end{array}$ & Innocent \\
\hline
\end{tabular}

political ethics by Augustine, and in what shape they appear in the new context of Hincmar's work.

The following list contains themes that run through the De regis persona et regio ministerio. Discussion of them will illuminate how Hincmar understood and reused Augustinian political ethics and political thought:

1 that political power and military success are always ordained by God and are always just;

2 that a rex bonus is iustus and means felicitas to the people, while a rex malus is iniustus and means infelicitas to the people;

3 that morally correct Christian governance requires humilitas on the part of the ruler as well as putting his power at the service of God, the 'church' and the people;

4 the meaning of the term felicitas in the context of worldly Christian rule and its relation to beatitudo;

5 belligerare as necessitas and its relation to felicitas;

6 the value of belligerare and pax;

7 the legitimation of violence - be it military violence or physical punishment including capital punishment - on the authorisation of God or the ruler who is divinely empowered (drawn and adapted from Augustine and St. Paul);

8 that the Christian ruler serves God by enacting iustitia on God's behalf, compelling its observance and reproving the wicked by amor iustitiae (how does Hincmar's understanding of iustitia relate to Augustine's and Cicero's? 
in what way does it differ from Augustine's notion of iustitia which is the precondition for a civitas Dei?);

9 that it is the ultimate aim of any Christian leader to apply the right measure of misericordia in order to achieve iustitia (drawn and adapted from Augustine and Cicero).

The content of the De regis persona et regio ministerio will be explored in chronological order and with emphasis on the mentioned themes. In the treatment of the last two themes, I will furthermore engage with the argument made by R. Dodaro in the Augustinus-Lexikon s.v. iustitia..$^{95}$ Dodaro claims that in some letters to public officials and authorities engaged in secular pursuits, Augustine outlines an argument concerning the transformation of the four virtutes civiles beyond the fundamental level of virtue attained by pagan politicians who lack vera pietas. He maintains that, by allowing their conception of iustitia to be transformed by fides, spes and caritas, Christian politicians will fight wars in a more virtuous manner than that which is sustained by the Roman concept of bellum iustum, and that they will punish offenders with iustitia tempered with misericordia. I will investigate how Hincmar brings to bear this correspondence together with quotations from the De civitate Dei that relate either to the Christian Roman emperors or to Cicero's model of a just social order. The question will be posed of what function is played by Hincmar's resorting to Augustine's discussion of Christian leadership.

As has been established, Augustinian influence is already present in CAP. I. Hincmar quotes a sentence from Augustine's De dono perseverantiae: "Nothing is done that is not done or justly permitted to be done by God [...]." 96 The content of this sentence can also be found in Gregory the Great's Moralia in Iob. Hincmar then expands on the meaning of the quote by saying that boni reges ("good kings") are good because they have God's grace and they reign because God makes them reign, while mali reges ("bad kings") are bad by their own misconduct and they reign because they are permitted to reign by divine judgment, which is occasionally hidden but never unjust. ${ }^{97}$ By partly drawing on Gregory the Great, Hincmar adds that God permits the rule of bad kings in order to punish the people for their sins.

Even though the work is not quoted here, the same ideas are put forward in the first books of the De civitate Dei, where Augustine takes a stand on the gradual decline of the Roman empire, embedding this process into salvation history and assessing the heathen and Christian Roman 'states' by expressing particular approval of the Christian emperors Constantine I and Theodosius I. Although Hincmar mentions neither of these emperors explicitly, he unmistakably alludes to the last chapters $(24,25$ and 26) of Book V of the De civitate Dei by declaring that good kings reign by the grace of God, while bad kings reign merely because God permitted that they come to power. In Chapters 12-17 of Book V, Augustine expresses the idea that God rewarded the Romans' love of glory by giving them earthly fame despite the fact that they worshipped false gods, while in Chapter 34 of Book IV he maintains that the Jewish people were punished by dispersal for 
not having recognised Christ, despite the fact that they initially worshipped the true God. In Chapters 17, 21 and 33 of Book IV, Augustine interjects that God nevertheless grants political power and success to good and bad people, since his iudicium is occultum, but always iustum. (Hincmar quotes Chapter 17 of Book IV in CAP. XII., where he notes that God decides to whom he wants to give victory in war. In CAP. XIII. - again using Augustine - he asserts that victory is always given to the just party.) Augustine writes at the beginning of Chapter 21 of Book $\mathrm{V}$ : " [...] the true God, who gives happiness in the realm of heavens only to the pious; but the earthly realm to both the pious and the impious, just as it seems right to him, to whom nothing seems right unjustly." things the one and true God guides and governs entirely, as it seems right; and if the reasons are hidden, are they unjust?" 99 The formula of the iudicium occultum, sed iustum, which resembles that of Hincmar in CAP. I., can be found in crucial Chapter 28 of Book XII of the De civitate Dei. There, Augustine claims that the civitas Dei and the civitas terrena emerge like 'states' as two societies from the first man Adam "[...] by God's hidden, but nevertheless just judgment."100 In the Augustinus-Lexikon s.v. iustitia ${ }^{101}$ it is noted that the concept of iustitia occulta or iudicium occultum is Augustinian. Throughout the De civitate Dei, Augustine refers to God's hidden justice and typically argues that God's judgment and reasoning are beyond human comprehension.

Hincmar's central message to Charles the Bald in CAP. I. is that all secular power is ordained by God and is therefore just. Charles the Bald as a ruler is not privileged simply because power has been granted to him by God; he is subject to God's judgment like any other human being and, in consequence, is obliged to follow the Christian moral code. Hincmar tries to set out what Augustine defines in Chapter 33 of Book IV: "And the earthly realms are therefore given by Him to both the good and the bad, in order that His worshippers, hitherto children in the development of their soul, should not desire these gifts from Him as something highly esteemed." 102

A next cluster of chapters thematically related in terms of Augustinian influence is CAP. V-VIII. CAP. V. contains the first lengthy quote from Augustine's De civitate $\mathrm{Dei}$ - and it has to be noted again that, due to the intermediary source material Hincmar uses, most quotations are not verbatim. Firstly, they are generally abbreviated. Secondly, the concept of imperare/imperium/imperator - the key element of Augustinian political discourse, which had been so ingeniously recycled by Alcuin - has mostly been replaced by regnare/regnum/rex. ${ }^{103}$ This expresses that there was no longer such stringent terminology attached to the function of secular rulership. In the De regis persona et regio ministerio. it appears that, for Hincmar, a ruler was essentially a ruler. Kings as well as emperors could take Constantine I and Theodosius I as models of Christian rulership. For Augustine and Alcuin, the title of imperator was much more clearly defined. It referred exclusively to a ruler who was ruling over multiple gentes and had the supremacy over other rulers in power. Alcuin used this concept of imperator based on Augustine in order to justify Carolingian rulership by an emperor in contrast with a king. With regard to Hincmar's conception of empire, Nelson writes: "Churchmen tended to be 
preoccupied with politics at the level of the kingdom, and the idea of empire, like the collective responsibility of Carolingian brother-kings for the one Church, came to mean little to the aged Hincmar. It had been resurrected to legitimise Frankish imperialism. Frankish divisions made it hard to sustain." 104 Devisse, likewise, thinks that the division of Francia at the Treaty of Verdun in 843, which brought into being the cores of three kingdoms, ${ }^{105}$ weakened the imperial idea established under Charlemagne. Devisse maintains: "Hincmar n'a attaché que très peu d'importance à la function et au titre impériaux: c'est un homme d'après Verdun [...]." ${ }^{106}$ He says that "il semble bien que, pour lui [Hincmar], l'empereur, après la mort de Lothaire $1^{\text {er }}$, soit un roi local qui a reçu une dignité supplémentaire, rien de plus." ${ }^{107}$ Nelson, however, raises an additional point. She contends that in the case of Charles the Bald, the title of imperator implied that "Charles was a ruler over more than one people." 108 Furthermore, based on the label "so-called emperor of Italy," which Hincmar uses with regard to Emperor Louis II in the Annales Bertiniani (written by Hincmar from 861 to 882 ) and which implies a narrow territorial circumscription, Nelson supposes that Hincmar was one of the promoters of this definition of Charles the Bald's imperial title. ${ }^{109}$ Although Nelson points out that at the beginning of the seventh century the composer of a treatise on official posts had extracted Romanity from this hegemonial conception of empire, which C. Erdmann termed a "Rome-free" imperial idea, she recognises the relation of this medieval conception to that of the Christian Roman empire, which also had a "multi-provincial" character. ${ }^{110}$ In conclusion, one may say that Augustine and Alcuin's concept of imperator was not unfamiliar to Hincmar, but it was clearly diluted or simply less relevant to Hincmar's concerns.

In CAP. V., Hincmar lays out the fundamental moral precepts of a Christian ruler by quoting from the eminent Chapters 19 and 24 of Book V of the De civitate Dei, where Augustine expands on the characteristics of the Christianos imperatores felices ("happy Christian emperors") - replaced in Hincmar's text by Christianos reges felices ("happy Christian kings"). Good Christian kings who have the skill of ruling are thus associated with the idea of felicitas ("happiness"). The "happy kings," it says, have to make their power serve God, the 'church' and the promotion of the Christian faith. They need to fear, love and worship God. They have to prefer the realm of God to the earthly realm. They ought to use their penal power exclusively for the necessity of the governance and maintenance of the 'state'. All this they must do, not because of any zeal for worthless glory, but because of their love for "eternal happiness" (felicitas aeterna).

Two Christian virtues, which prove to be indispensable to rulership, since they occur repeatedly in the De regis persona et regio ministerio, are included in Augustine's passage from Chapter 24 of Book V: misericordia ("forbearance") and humilitas ("humility"). Forms of misericordia and humilitas can also be found in the celebrated Chapter 26 (on Theodosius I) of Book V of the De civitate Dei. ${ }^{111}$ In accordance with these chapters, Hincmar sets the moral standards for King Charles the Bald: a careful exercise of "forbearance"; to live in "humility"; to reject the gifts and flatteries of subordinates; to correct the evil as well as not to spare family members and close ones if they acted improperly. Hincmar reasons 
that "forbearance" and "humility" are essential virtues since they grant the rulers the willpower to resist the dangerous temptations that worldly power implies (CAP. III., V., XVIII., XIX., XX., XXVIII., XXX. and XXXI.). What is more, King David features as an exemplary king who represents these virtues (humilitas/humilis in CAP. III. and XXX.; misericors/misericordia in CAP. XXXI.).

In CAP. VI., Chapters 3-4 of Book IV of the De civitate Dei are quoted. ${ }^{112}$ By using Augustine, Hincmar explains why and to whom - as soon as the true God is worshipped and the Christian code of conduct is observed - it is profitable when good rulers reign "continually and far and wide." Augustine's argument is that when they reign "continually and far and wide," it is less useful for the rulers themselves than it is for the people. For, as far as they are concerned, their piety and probity will do in order to gain vera felicitas ("true happiness"), which Augustine specifically defines as "spending this life well and one day attaining eternal life." 113 It is emphasised that the rulership of the good is beneficial to the conditions and human affairs on earth. While the rulership of the bad mainly affects the rulers themselves, it does not affect their subordinates, since righteous subordinates do not sin by obeying bad rulers (St. Paul). They themselves remain free. However, bad rulers are slaves to each of their own sins. Hincmar then attaches the rhetorical question "In the absence of justice, what are realms, therefore, but big bands of robbers?" 114 - with which Augustine opens Chapter 4 of Book IV - to the end of CAP. VI. ${ }^{115}$

The central piece of information to Charles the Bald is: if those who hold a political office are bad, they will only harm themselves (as sons of the Christian God) by minimising their chances of attaining eternal life. For, as sons of God, they are equal with everyone else. This clearly shows that Hincmar assumes a separation of the political function and the person of the ruler. ${ }^{116}$ If the holders of power aim at reigning longe lateque ("far and wide"), i.e. by military expansion, they should not do so in their own interest, for it will not be them but the people who will profit. Likewise, the people will be judged by God solely on the basis of the quality of their personal relationship to Him. Only because all power derives from God, the people do not sin by following the orders of the holder of the governmental office but in fact owe obedience to him. This idea developed from St. Paul (Rom 13:1-7), together with the argument founded on Augustine and Gregory the Great in CAP. I. - that the unjust ruler comes to power because of disorder in society which is attributable to the people's sins - bars any insurrection against those in political office. Tyrannicide and even deposition by force are unlawful since the seizure of power by a tyrant is merely the result of a disturbance of the social order. ${ }^{117}$ The people must endure the tyrant they themselves have brought into existence. In general, Hincmar's texts put forward for consideration the notion that obedience to a holder of a political office might find its limits when the holder goes against the teachings of Christ. This would mean that a ruler is only elevated above the other people in his function of holder of power as long as his governance is in line with Christian doctrine. ${ }^{118}$ However, according to Hincmar, it would be exclusively the clergy's responsibility to take a stand against an unjust ruler. ${ }^{119}$ The extent to which Hincmar believes the clergy should 
be entitled to intervene has been investigated in the analysis of the Expositiones ad Carolum Regem.

In CAP. VII. and VIII., the value of belligerare ("to wage war"), regnum dilatare ("to expand the realm") and pax ("peace") ${ }^{120}$ is debated with reference to Augustine. (CAP. VII. quotes from Chapter 15 of Book IV of the De civitate Dei.) CAP. VII. contains the following statement from Augustine: "[...] to wage war and expand the realm by conquered races is perceived as happiness by the bad, as necessity by the good." 121 Afterwards, Augustine adds nuance to this idea: "But since it would be worse if the unjust dominated the juster ones, also this is not unsuitably called happiness." 122 Then he continues by saying that beyond doubt it is a "greater happiness" (felicitas maior) to have a good neighbour than to subjugate a bad neighbour. For it is a bad desire to wish to have someone to hate or fear, in order to have someone to subjugate. ${ }^{123}$ It should be highlighted here that felicitas in this context seems to refer to something like a "happy state of affairs in this world" and necessitas to a "necessary state of affairs in this world." Moreover, felicitas maior is used in order to denote the preferred "state of peace on earth" with one's neighbour as opposed to the "state of war on earth," which may be called necessitas or even felicitas (in the case of an unjust neighbour). (Earlier in this chapter Augustine also uses the phrase feliciores res humanae ${ }^{124}$ to refer to the "happier human circumstances" of having small but peaceful realms.) CAP. VIII. has similar content. Drawing on Augustine, ${ }^{125}$ Hincmar proclaims: "Necessity should make war, in order that, after discord has been stilled, peace can be restored." 126 In other words, in CAP. VII. and VIII., Hincmar explains to Charles the Bald that war serves the purpose of peace.

The concept of felix/felicitas has so far occurred in various senses and combinations (e.g. felix as an attribute to the "good Christian ruler" in this world, felicitas as a "happy state of affairs in this world," felicitas with complements such as in regno caelorum, aeterna and vera referring to "eternal life" and the instance of felicitas maior referring to the "state of peace on earth" which is preferred to the "state of war on earth"). Since felix/felicitas does not feature as a lemma in the Augustinus-Lexikon, it will be explored further. Its appearance in the De civitate $D e i$ will be juxtaposed with its use by Hincmar.

As has been established in the third chapter of Part I, the correct English translation of the Latin adjective felix is "happy." Correspondingly, the Latin noun felicitas translates as "happiness." In the De civitate Dei, Augustine confers the attribute of felix on the Christian Roman emperors. The concept of felix/felicitas occurs particularly in Chapters 24 and 25 (on Constantine I) of Book V. ${ }^{127}$ Likewise, it has been confirmed that beatus signifies "blessed" or "made holy," and, accordingly, beatitudo denotes "blessedness." Beatus essentially means "happy" but in addition has the connotation of "being endowed with divine favour and protection." All the statements already discussed from the first five books of the De civitate Dei have shown that in the Augustinian political discourse, felicitas is used exclusively with reference to worldly happiness - and in the cases where it does allude to "eternal life" it is, as we have seen, complemented by in regno caelorum, aeterna, vera and also plena. ${ }^{128}$ Only by these complements 
felicitas becomes really synonymous with beatitudo ("blessedness"). At least in the first five books of the De civitate Dei, which focus on the Roman secular power, Augustine is consistent in his usage of these concepts. By being very precise in his application of this terminology, Augustine consciously avoids any potential association of worldly rulers - including Christian Roman emperors with "divine privilege" in the sense of a prospect of "eternal life." In this perspective, the concept of felix/felicitas ("happy/happiness") stands in opposition to that of beatus/beatitudo ("blessed/blessedness").

If we return to Hincmar's De regis persona et regio ministerio, we find that in CAP. X., concerned with the art of warfare according to Christian ethics, Hincmar recycles Augustine's letter to Bonifacius in a manner that is not in agreement with the political discourse underlining the De civitate Dei: a long extract from Augustine's epist. 205 ad Bonifacium features in CAP. X. ${ }^{129}$ The occurrence of the second person singular creates the impression that King Charles the Bald is the direct addressee of this writing. The central piece of instruction is at the end of the quotation, where Augustine writes:

For if faith, once promised, is to be held even with the enemy against whom we wage war, by how much more then is it to be held with the friend for whose sake we go to war? The will demands to have peace, necessity to have war, so that God liberates us from necessity, and preserves us in peace. For peace is not striven for in order to revive war, but war is waged in order to get peace. Therefore, also by battling thou shalt be pacific, in order that you lead those whom you fight to the advantage of peace by vanquishing them. For blessed are the pacifists, says the Lord, since they are called sons of God. ${ }^{130}$

The extract contains Mt 5:9 of the Beatitudes in the Sermon on the Mount. The use of the attribute of beatus takes on a new meaning in this context where a Christian ruler is addressed. In Hincmar's 'mirror for princes', the concepts of felix/felicitas and beatus/beatitudo are not clearly separated in their use. They seem to be merged.

Augustine, who uses this Latin terminology consistently in the first five books of the De civitate Dei, would not have integrated this Bible quotation into a discourse on secular rulership - in order to avoid associating a worldly ruler with "divine happiness" and "eternal life." Nevertheless, regarding the question of the use of "happy"/"happiness" and "blessed"/"blessedness" in the De civitate Dei, there is one remarkable instance in Chapter 13 of Book IX, ${ }^{131}$ where Augustine is merging these two concepts in a similar manner to Hincmar. In this case, however, Greek terminology is involved. Chapter 13 of Book IX analyses the similarities between the daemones ("demons") and the dii ("gods"), on the one hand, and the daemones and the homines ("men"), on the other. Augustine reflects on the Platonic definition of daemones provided by the Latin prose writer Apuleius, who placed the daemones in the middle between the dii and the homines and established the five characteristics of the daemones: "ensoulment" and "rationality" (two features that all three living beings have in common), the "aerial consistency 
of the body" (a feature pertaining to the daemones only), "eternality" (a feature borrowed from the dii) and "passion" (a feature borrowed from the homines). It is made apparent that the derivation of the latter two characteristics results in the middle position of the daemones between the dii and the homines. Augustine furthermore explains that these characteristics of "eternality" and "passion" which the daemones have in common with the dii and the homines respectively bring about their "wretched eternality" or "eternal wretchedness." Augustine states: "That is, however, the very wretched eternality or eternal wretchedness of the demons." ${ }^{\prime 32}$ Augustine goes on to say that, since Apuleius did address the passionate nature of the daemones, he should also have called it "wretched." Because of the demon-worshippers among the Platonists, however, he was reluctant to do so. In the following sentence, where Augustine highlights the polarity between the daemones, whom Augustine terms miseri ("wretched") on account of their "passion," and the dii, whom he terms beati ("blessed") on account of their "blessedness," the merging of the concepts of "happy"/"happiness" and "blessed"/"blessedness" occurs. Augustine contends: "If, therefore, the blessed are correctly called happy, the demons are not happy, those who have been placed in the middle between the men and the gods." ${ }^{133}$ The adjective eudaemon, -onis is derived from the Greek عibaí $\mu \omega v$, -ovos, which means "blessed with a good genius," "fortunate" or "happy"134 and which is the equivalent of the Latin adjec-

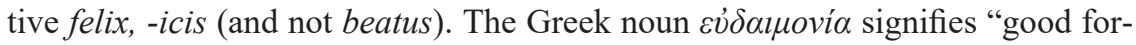
tune" or "true/full happiness" 135 and is the equivalent of the Latin noun felicitas. This suggests that there must be another word in Greek that expresses the concept of "blessed"/"blessedness." The Greek term that comes closest to the Latin term

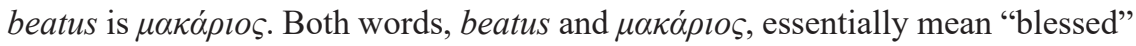
and may have a meaning similar to "excellent" when used as titles of the higher clergy (e.g. bishops). ${ }^{136}$ It thus seems that Augustine has merged the meanings of "happy"/"happiness" and "blessed"/"blessedness" in the sentence, where he says that "the blessed are correctly called happy." There is a Greek work, which may also be seen as belonging to the genre of literature providing direction on how to lead a life according to certain ethical principles. It is the Epistula ad Menoeceum ("Letter to Menoeceus") by Epicurus, dating from around $300 \mathrm{BC}$. In this manual of conduct, Epicurus in turn gives practical advice to Menoeceus on how to conduct his life by adhering to particular ethical prescripts. The text, which follows Aristotle (e.g. in ethics and logic), shows that Epicurus as well makes a clear distinction in his use of the concepts of "happy"/"happiness" (which appears as $\varepsilon \dot{b} \delta \alpha i \mu \omega v / \varepsilon \dot{b} \delta \alpha u o v i \alpha$ ) and "blessed"/"blessedness" (which appears as

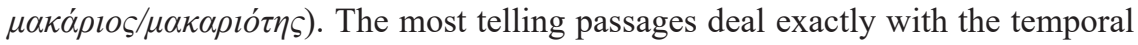
"happiness" achievable by men and the "blessedness" and "eternality" attributable to deity alone. Epicurus first maintains: "But the one who either says that the right time to engage in philosophy has not yet begun or says that the right time has passed, is like someone who says that the right time for happiness is either not there or no longer there," ${ }^{137}$ and then he carries on "[...] and so one must practise the things that bring about happiness, for if indeed it is present, we have everything, but if it is absent, we do everything to have it." ${ }^{" 138}$ Further down, he 
exhorts: "First of all, on the one hand, acknowledge god as an eternal and blessed living being, just as the common understanding of god outlines, attach to him neither anything that is alien to eternality nor anything that is incongruous with blessedness [...]." ${ }^{139}$ It remains to be said that in the De civitate Dei, for one reason or another, the concepts of "happy"/"happiness" and "blessed"/"blessedness" are evidently no longer enforced consistently in the passage ${ }^{140}$ where Augustine makes use of both Greek and Latin terminology.

Furthermore, there is the political term gentes that is worth consideration. When looking at the overall use of gentes in Hincmar's writing, it is noticeable that the author does not have the same understanding of this word as Augustine or Alcuin. He also does not use gentes as often. Considered as a whole, the nouns gentiles and gentilitas as well as the adjective gentilis - which all have a connotation of paganism (since from the fourth century onwards gentiles took the place of gentes in the language of the 'church' councils ${ }^{141}$ ) - are much more frequent in Hincmar's works. Strikingly, there are only two instances in the De regis persona et regio ministerio in which gentes appears with Augustine's specific meaning of "less influential groups of people who are to open up to conversion." They can be found in CAP. V. and CAP. VII., which are dealing with the use of political power according to Christian ethics. In both cases, gentes is part of a quote from Augustine's De civitate Dei. CAP. V. quotes from Chapter 24 of Book V, while CAP. VII. quotes from Chapter 15 of Book IV. In these passages from the De civitate Dei, gentes appears in clusters of words that have been established as characteristic of Augustine in contexts concerned with secular power and military expansion; Chapter 24 of Book V contains the phrase gentes imperare ("to rule over races/tribes/nations"); in Chapter 15 of Book IV., the formulas perdomitis gentibus dilatare regnum ("to expand the realm by conquered races/tribes/ nations") and vicinum subiugare ("to subjugate the neighbour") are included. These findings show that in contexts where Hincmar reflects on secular and military power, he makes use of passages from the De civitate Dei, and, moreover, those he selects contain the term gentes in Augustine's particular sense.

Apart from gentes, the only related word that can be found in the De regis persona et regio ministerio is gentilitas ${ }^{142}$. It occurs in CAP. IV. and is part of a quote from Ambrose's De officiis. Ambrose here uses gentilitas in the sense of "paganism." The sentence containing gentilitas reads:

If you assist the one who declares a severe fight against a widow and orphans, or attempts to seize their possessions by any force, the liberality is not proven, if someone tears what is granted to the one away from the other, desiring it unjustly, and believing it to be distributed justly: not before at some point, just as the well-known Zachaeus, you give back fourfold to the one you have cheated, and compensate for the vices of paganism with eagerness of faith, and with action of a believing man. ${ }^{143}$

This quotation expresses that gentilitas, which explicitly refers to "paganism" (unlike gentes), is directly associated with iniustitia. For Ambrose (and for 
Augustine in his early texts, in cases where he applies iustitia to social and political ethics), the congruence of the Biblical-Christian and philosophical-juridical senses of iustitia means that, as a virtue, it can be practised in its most genuine form (as vera iustitia) only by those who practise vera pietas, which consists in the knowledge and love of the true God. In consequence, pagans (and other nonChristians) are not able to practise vera iustitia. ${ }^{144}$

CAP. IX-XI. are influenced by Augustine largely on the basis of St. Paul's political theology of the love of one's neighbour. They define the cases in which and the conditions under which the commandment "Thou shalt not kill" is invalid. In CAP. IX., Hincmar chooses a passage from the De civitate Dei (Chapter 21 of Book I) in which three important notions of Augustine's understanding of iustitia are included: iustissimae rationis imperium ("order of the justest reasoning"), lex iusta ("just law") and fons iustitiae Deus ("God as the source of justice"). First, Augustine maintains "[...] and therefore have these by no means acted against this precept, in which it says: Thou shalt not kill, who have waged war under the authority of God or have punished criminals with death, supporting a person of public power according to His laws, which is an order of the justest reasoning," 145 then he concludes "These therefore have been made the exception, when either a just law in general or God himself as the source of justice specifically commands the killing of anyone who has killed a man or himself, or whoever is entangled in the crime of homicide." 146

According to the Augustinus-Lexikon s.v. iustitia, Augustine makes reference to "a sense belonging to the inner man" by which reason is able to discriminate between iustitia and iniustitia. ${ }^{147}$ It is claimed that Augustine indicates in both the De civitate Dei and the De Trinitate that all humans are able to identify iustitia, even in the case that they themselves are not righteous. This explains the essence of iustissimae rationis imperium ("order of the justest reasoning") and the ease with which Augustine uses the term lex iusta ("just law") in the above quotations. Augustine's argument is grounded on St. Paul, in whom, he argues, the people recognise the forma iustitiae ("form of justice"). By loving this form, their capability to comprehend and love iustitia grows, and they become more righteous. This is how Augustine perceives the interaction between the mind's knowledge and love of iustitia and their unity in the mind's knowledge and love of God. In alleging that God is fons iustitiae ("source of justice"), Augustine puts forward that iustitia is knowable only as far as God is known and that God is only known insofar as He is loved.

By relying on Augustine and the mentioned Augustinian terms and concepts, Hincmar proves that God's and the ruler's orders are recognised as "just" by all humans. They are recognised as "just" even to the extent that the love of neighbour and the commandment "Thou shalt not kill" take a subordinate position. This clause - that God's and the ruler's laws compel the people's observance - holds throughout the De regis persona et regio ministerio.

In substance, CAP. XVI-XVIII. propose that the goal of legislation is the promotion of the Christian religion and moral code. This is achieved by the ruler who acts in the service of God (see CAP. XVI.) and can only be realised when law 
and order are enforced. If necessary, means of coercion may be applied in order to force to the iustitiae observatio ("observance of justice") (see CAP. XVII.). The impetus for reproving the bad is amor iustitiae ("love of justice") (see CAP. XVIII.). This is entirely in line with Augustine's social and political ethics, where amor iustitiae acquires the ethical function of being the motive behind the soul's effort to overcome concupiscence and $\sin .{ }^{148}$ Eventually, Hincmar draws the conclusion; the one who advocates iustitia ("justice") and uses the penal power in the right way serves the Christian God. This statement is made in CAP. XVIII., which is arguably where Augustine's political ethics and political thought show most clearly their impact on Hincmar's perception of Charles the Bald's realm as a Christian 'state'. As will be subsequently displayed, the entire argument regarding the correct exercise of iustitia ("justice") in the subsequent chapters, including the use of the penal power and death penalty, is based on this inference.

CAP. XX. is entitled "Whom the leader or judge should rightly be allowed to forgive." It gives reasons by citing evidence from firstly Gregory the Great and secondly Augustine. At the beginning of the chapter, Hincmar writes: "In the Gospel Homilies ${ }^{149}$ the blessed Gregory therefore shows whom the leader or judge should rightly be allowed to forgive, under a just and merciful decider, who forgives the converting and repenting." ${ }^{150}$ The key point Hincmar makes in CAP. XX. is that the one who offers hope for moral improvement deserves to be forgiven by the leader or judge, while against the recidivist a strict judgment is necessary. In any case, Hincmar says by quoting from Augustine's Sententiae, ${ }^{151}$ a sinner will eventually be disciplined for his offence: "Sins, whether minor or major, cannot go unpunished, since they are punished either by the repenting person or by the judging God. For godly vengeance ceases if human conversion precedes. For God indeed loves to spare the confessing and not to judge those who judge themselves." 152 By combining forbearance with rational judgment, a decider acts in the service of the Christian God.

CAP. XXIII-XXIV. are concerned with the purpose and use of the penal power and death penalty. The question of the lawfulness of the death penalty is debated with reference to Augustine. The chapters are headed "That holy men have punished the accused with death by law in order to inflict fear" (CAP. XXIII.) and "That killing a man is not always criminal" (CAP. XXIV.) In both cases, Hincmar argues in favour of the death penalty. He contends that it is a ruler's right to impose the death penalty. Besides the usual purpose of punishing the offender, the death penalty may have the function of serving as a deterrent against further serious violations of the law on the part of the people. The imposition of the death penalty by the Christian ruler is lawful because it compels to the iustitiae observatio ("observance of justice") in the Christian society.

CAP. XXVII. and CAP. XXXI. are entitled "That laws from a just leader are to be officially acknowledged by anyone" and "Whether one should exercise forbearance with regard to the biggest and official crimes." They both include quotations from Augustine. In CAP. XXVII., Hincmar's reasoning is: a Christian 'state' must serve the Christian God. If a Christian ruler, who advocates iustitia ("justice") and uses the penal power in the right way, serves the Christian God, the people need 
to obey his command. Furthermore, by referring to Augustine's De vera religione (the same passage Hincmar already quoted in 868 in the Quaterniones ${ }^{153}$ of the Expositiones ad Carolum Regem), Hincmar says about the Christian secular authorities who are in charge of enacting laws: even though men judge over the temporal laws when they legislate, once a law has been made, a judge is not allowed to judge over it, but only according to it. Hincmar insists that not only the Christian people but also their leaders must follow the law that is authorised by the Christian God. In CAP. XXXI., Hincmar discusses the procedure in the event of felonies and crimes against the 'state'. Again, by using Augustine inter alia, Hincmar advises that the repentant may be spared - however, only to the extent that peace and order in the Christian society are maintained.

As we have seen (especially in the discussion of CAP. IX.), iustitia in the Biblical and Christian sense is a virtue that is closely linked with the love of God in the first instance and the love of neighbour (which is also reflected in the Decalogue) in the second instance. In his early works, Augustine started to apply this Christian notion of iustitia to social and political ethics. His reasoning was that, because the right love of God involves the right love of neighbour, the 'church' instils the teaching that relations between family members, citizens as well as between subordinates and superiors (e.g. the people and their ruler) must be maintained by caritas, which iustitia compels. ${ }^{154}$ In early Christianity, it was a matter of course that pietas and caritas form a pair. However, early Christianity was not in the first place concerned about the 'state'. Caritas was considered to be a responsibility of the individual rather than the 'state'. Only when Christianity was made the 'state' religion in the fourth century, caritas started to become a public concern of ruler and citizen. Along these lines, caritas gained importance in Augustine's political ethics as one of the foremost civic duties. The presence of caritas in the political sphere also brought a new, Christian dimension to the concept of iustitia. The merging of Biblical-Christian with philosophical-juridical senses of iustitia in Augustine's political thought resulted in the belief that vera iustitia presupposes vera pietas, whose essential feature is the knowledge and love of the true God (as we have seen in the instance where gentilitas is identified with iniustitia in CAP. IV. as part of a quote from Ambrose's De officiis).

From this, it follows that, throughout the De civitate Dei, Augustine argues that a societas iusta is one that worships God correctly. This societas is synonymous with the civitas Dei, since in the De civitate Dei Augustine - based on Cicero - establishes iustitia as the precondition for a civitas Dei. Already in the Confessiones, Augustine says: "iusta est societas hominum, quae servit tibi" (conf. 3,17). ${ }^{155}$ The content of CAP. XVI., XVII. and XVIII. of the De regis persona et regio ministerio essentially suggests that Hincmar wants Charles the Bald's 'state' to be a "societas hominum, quae servit Deo," i.e. a 'state' that obeys the divine will in all things. However, it has not yet been evaluated what according to Hincmar the notions of iustitia (and pax) imply, which form the basis of such a 'state'. In the following, I will therefore elaborate on Hincmar's concept of iustitia in comparison with Cicero's, Augustine's and Alcuin's understandings of iustitia (and pax). The aim will be to ascertain what Hincmar's perception of 
these ideas tells us about his view of Charles the Bald's Christian 'state' and its particular association with God.

The concepts of iustitia (and pax) have emerged as most prominent in Hincmar's reflections on the 'state', its order and its government. It has further turned out that in the De regis persona et regio ministerio, Hincmar treats iustitia (and pax) predominantly in connection with Augustine or even the De civitate Dei. CAP. XVIII., where Cicero's ideas of iustitia and misericordia are reflected in a quote from the De civitate Dei, has been defined as the most critical chapter in terms of influence of Augustinian political ethics and political thought. For this reason, we cannot escape analysing the differences in Cicero's, Augustine's, Alcuin's and Hincmar's notions of iustitia (and pax) and investigating how they affect the perception and valuation of a worldly 'state'. A summary of each author's position will pave the way for a subsequent conclusion.

\section{Cicero}

The concept of iustitia ("justice") in the thought of Cicero is most prominent in his model of social organisation. His thinking is influenced by Aristotle's maxim, "man is by nature a political animal." In Cicero's De re publica, Scipio holds:

'Consequently,' says Africanus, 'a 'state' is the affair of a people; however, a people is not any crowd of human beings united in any sort of way, but a crowd of great number associated in a consensus with respect to justice and welfare for the community. But its primary cause of assembling is not so much helplessness as a certain uniting of men as if produced by nature. $[\ldots]^{3156}$

The quotation from the De re publica shows that for Cicero, justice is fundamental to the orderly organisation of the 'state'. Cicero's statement is the starting point for Augustine's debate around the definition of the 'state' in the De civitate Dei and contains Cicero's definitions of 'people' and 'state'. According to Cicero, a 'state' is only the "affair" (res) of a people if someone governs it justly - be it a king, a few aristocrats or the people collectively. ${ }^{157}$ Cicero disapproves of the Romans' loss of moral values over the years ${ }^{158}$ and promotes the legitimacy of certain people being in power and ruling over other members of the 'state'. ${ }^{159}$ Cicero presents a series of connected allegories, proceeding from God, who, being the supreme commander, rules over man, to the human spirit that is in charge of the human body, and, at last, to reason, which controls human desires as well as other evil stirrings of the soul to the benefit of men. ${ }^{160}$

\section{Augustine}

In the De civitate Dei, Augustine expatiates on Cicero's example and determines that true iustitia ("justice") in a 'state' can only be attained if God is the commander of all people; the human spirit is in charge of the human body, and reason controls human desires and other evil stirrings of the soul. By adopting Cicero's 
principle that justice is a prerequisite for a 'state', he professes that the Roman power is not and has never been a 'state'. ${ }^{161}$

Augustine then admits that from a certain point of view the Roman power is nevertheless a 'state', ${ }^{162}$ and he therefore seeks to find a more appropriate definition for such an earthly community. ${ }^{163}$ Augustine retains Cicero's idea of a "state" (res publica) as the "affair of a people" (res populi) ${ }^{164}$ but changes his definition of 'people'; he argues that "a people is a rational union of a crowd associated in a concordant communion over things that it loves" (populus est coetus multitudinis rationalis rerum quas diligit concordi communione sociatus). ${ }^{165}$ Expressed in a different way, a 'people' is not "associated in a consensus with respect to justice,"166 but united by a mutual interest in whatever is loved. The Roman community is now a 'people' since it does not matter what the shared interest is that builds its common ground. Consequently, the "affair" of the Roman people is their "affair" and their 'state'. ${ }^{167}$ Augustine concludes that, just as the Romans, other earthly communities - such as the Athenians and other Greeks, the Egyptians and the Babylonians - are a 'people' who possess a 'state'. Each of these Augustine calls a civitas impiorum ("state of the impious"). ${ }^{168}$ Because their members do not acknowledge the Christian God as their supreme commander, these "states" lack true justice. ${ }^{169}$

Having seen Augustine's criticism of Cicero's definition of 'state' and the conclusion he provides in Book XIX, ${ }^{170}$ it appears that Augustine considers all worldly 'states' to be equally unjust. However, following his new definition of "people" in Book XIX, Augustine recommends that some worldly 'states' are superior to others from a moral point of view since people or 'states' can be judged according to the things they love as a community. A people or 'state' is the more virtuous, the more honourable, the matter is that is valued in common. ${ }^{171}$ A classification of worldly 'states' according to moral standards is possible for Augustine because he recognises a definition of the 'state' based on natural law alongside the other definition based on divine law. That Augustine corrects his first definition of 'state' in order to be able to rank some worldly 'states' higher than others reflects the conflict in the De civitate Dei between an acknowledgement and a denial of worldly power.

Augustine examines 'states' from an eschatological perspective and assesses different worldly 'states' according to their moral standards; he ranks the 'state' of the monotheistic Jewish nation at the bottom of the hierarchy. Then, in some respects superior to the Jews with regard to moral standards are, according to Augustine, other worldly 'states' prior to the foundation of Rome. Augustine argues that divine providence has decreed that two temporal realms are rated even higher, namely the pagan 'states' of the Assyrians and the Romans. ${ }^{172}$ Augustine presents the polytheistic Assyrians in the East as the typos ("pre-image") and the polytheistic/pre-Christian Romans in the West as the antitypos ("counter-image"). ${ }^{173}$ Both 'states' are two large and, in their own way, good ${ }^{174}$ worldly 'states' which parallel the civitas Dei. ${ }^{175}$ One of their functions for Christianity is that, due to their longevity, size and influence, they were able over a long period of time to secure $\operatorname{pax}$ ("peace") among the earthly community. ${ }^{176}$ Besides safeguarding peace, their 
significance in the context of God's providential plan is that the Assyrian empire as the typos is relevant for events pertaining to the Old Testament, ${ }^{177}$ while the Roman empire as the antitypos is relevant for the New Testament. ${ }^{178}$ At the top of Augustine's hierarchy of worldly 'states' are the Christian 'states'. Augustine expands on the Christian Roman empire and emperors, which are mainly praised. Prime examples are emperors Constantine I and Theodosius I. ${ }^{179}$ However, Augustine's praise of the Christian Roman emperors is restricted to deeds that are historically verifiable. The main focus lies on the Roman emperors' achievements in the promotion of the Christian faith. Notwithstanding, in Augustine's view, all members of a 'state', including its ruler, must place themselves completely under the authority of God in order to achieve true iustitia ("justice"), the essential precondition for a 'state' that can legitimately be called a civitas Dei. This, according to Augustine, cannot be achieved on earth.

In Part I of this book, it has been observed that Arquillière, who has F. Dvornik's ${ }^{180}$ support with regard to his theory of Augustinisme politique, was aware of the conflict manifested in the De civitate Dei. Arquillière asserted, contrary to Bernheim, that Augustine does attribute a legitimate power, in conformity with God's providential plan, even to the ancient pagan realms before the emergence of Christianity. According to Arquillière, Augustine also pleads (in line with St. Paul and the patristic tradition) for obedience on the part of the people to any ruler - unless the ruler's will is against Christian moral principles. ${ }^{181}$ Dvornik notes that some scholars, including Bernheim, assumed that Augustine considers the good deeds of the citizens of the civitas Dei alone to be legitimate virtues. While Dvornik admits that for Augustine the legitimate virtues which grant men eternal salvation are the deeds done by members of the civitas Dei, he emphasises that Augustine at the same time also accepts the existence of natural virtues, which prevailed among the heathen Romans and helped them to expand and protect their 'state'. ${ }^{182}$ In the Augustinus-Lexikon s.v. iustitia, Dodaro argues along these lines. ${ }^{183}$ Arquillière, Dvornik and Dodaro rightly give prominence to the natural dimension of the concepts of iustitia and pax. Both concepts permeate the De civitate Dei and have the purpose of establishing true order in human society. ${ }^{184}$ They function in like manner in the civitas Dei as in the civitas terrena. Their double meaning - i.e. their natural vs. divine sense - can be defined as follows: the natural form of iustitia or pax $x^{185}$ is the iustitia or pax given by men to men; the divine form of iustitia ${ }^{186}$ or pax ${ }^{187}$ is the iustitia and pax given by God to men. As soon as the concepts of iustitia and pax are spiritualised, they are determined by the Gospel's main law of love of God and of one's neighbour. Arquillière stated that Bernheim saw correctly the importance of the Augustinian concepts of iustitia and pax in later (medieval) political reflections. Bernheim seemed not to have realised that for Augustine their natural, worldly forms likewise have a substantial value for life on earth. ${ }^{188}$ Arquillière maintained that the devaluation of the natural forms of these goods started in Merovingian times when kingship gradually began to be seen as subservient to the 'church'. Accordingly, earlier medieval thinkers, such as Gregory the Great and Isidore of Seville, and later Smaragdus of Saint-Mihiel and Jonas of Orléans, retained from Augustine merely the extreme 
statements that devalued the earthly 'state'. Dvornik believes that in Isidore's texts from the late seventh century, the idea of the 'state' based on natural law had almost disappeared. He reasons that Isidore regards the 'state' as necessary only for the defence and protection of the 'church'. ${ }^{189}$ This shift in focus, away from the recognition of the natural law of the 'state', Arquillière termed Augustinisme politique. ${ }^{190}$ What is most striking is that Arquillière saw exceptional circumstances under Charlemagne's reign; he argued that under Charlemagne, Catholicism did not exist as a separate entity because of the merging of political and religious affairs. ${ }^{191}$ While Augustine had separated Catholicism from political affairs, Augustinisme politique did not. Under Charlemagne, iustitia and pax were wholly safeguarded by the omnipotent emperor. ${ }^{192}$ The political and religious domains were both successfully dominated by Charlemagne. He was the one medieval emperor who, by taking on the task of implementing iustitia and pax could give to these concepts the religious meanings they had adopted since Merovingian times under the influence of Augustinisme politique. ${ }^{193}$

\section{Alcuin}

As the research on Alcuin has conveyed, Arquillière presumably based his argument on Alcuin when he affirmed that Charlemagne, by implementing iustitia ("justice") and pax ("peace") in a certain way, could give to these concepts the religious contents they had adopted since Merovingian times under the so-called Augustinisme politique. A re-evaluation of relevant passages from Alcuin's Epistolae will expose a relation in the texts between Alcuin's use of the notions of pax, iustitia and civitas Dei as well as the figures of Old Testament kings.

Epist. 41, written to the king, is the first letter in which Alcuin draws a parallel between Charlemagne and King David. ${ }^{194}$ In the text, Alcuin puts forward that, similar to David, elected and loved by God, ${ }^{195}$ Charlemagne conquered the neighbouring tribes and enlightened them about the true faith as well as the law of God. In Alcuin's description, both Charlemagne and David appear as kings of a people that have God as their leader. Alcuin portrays Charlemagne and David as two rulers who are ruling entirely in accordance with God's will and are implementing the law of God. This parallel is then followed by another comparison drawn between Charlemagne and Christ. Alcuin evidently links Charlemagne and David with Christ by pointing out that Christ is of the house of David. Alcuin avails himself of the formula populus Christianus ("Christian people") in order to make reference to Christ's heavenly realm.

Epist. 217, written to King Charles the Younger, supports the claim that Charlemagne and his heirs are higher in rank than all the former Christian rulers. ${ }^{196}$ The main motive of Epist. 217 is the celebration of the royal coronation of the second son of Charlemagne. Charlemagne is again referred to as David when Alcuin declares that the coronation took place with Charlemagne's consent. In the following, Alcuin indicates that, in order for his wishes to come true, Charles the Younger must first and foremost implement iustitia ("justice") and exercise misericordia ("forbearance") - the two essential components that constitute a 
God-placating rule, according to King Solomon. Alcuin once more chooses the term populus Christianus, which is applied to Christ's heavenly realm in Epist. 41. By availing himself of Solomon, Alcuin draws a comparison between Charles the Younger and Solomon and establishes a role model of a true Christian king. However, shortly afterwards, Alcuin simply advises Charles the Younger to follow the example of his father Charlemagne. Charlemagne is then presented as rector et imperator populi christiani ("ruler and emperor of the Christian people").

In Epist. 177, where Alcuin exhorts Charlemagne to intercede on the side of Pope Leo III, he also makes use of the pseudonym David ${ }^{197}$ Alcuin explains that Charlemagne is the only nominee who has the right to direct the judicial investigation. Alcuin addresses Charlemagne as decus populi christiani ("glory of the Christian people"). Besides the military defence of the Christianum imperium ("Christian empire") and the protection of the Catholic faith, Alcuin mentions the spread of the principles of justice as a third core responsibility of the Christian ruler - which in the course of the letter becomes increasingly important when Alcuin portrays Charlemagne as the only man alive endowed with the power to fulfil what pleases God. The acts of performing justice and making law are repeated later on in the epistle among the other duties of the Christian ruler. As a reward for accomplishing these tasks, Alcuin maintains, God will bless Charlemagne's sons richly and preserve the royal throne to all of his descendants, just as he did with his favourite, King David.

In the De civitate Dei, it is argued that true iustitia ("justice") in a 'state' can only be achieved if God is the commander of all people and all of them obey Him. ${ }^{198}$ This, Augustine finds, cannot possibly be realised on earth, wherefore a worldly civitas Dei becomes inconceivable. However, Epist. 41, Epist. 217 and Epist. 177 propose that Alcuin thinks otherwise as far as the Carolingian 'state' is concerned; in Epist. 41 Alcuin describes both Charlemagne and Christ as descendants of King David. In Epist. 41, populus Christianus occurs with reference to the people of the kingdom of Christ, while in Epist. 217 and Epist. 177 the same formula stands for both the people of Charles the Younger and the people of Charlemagne. Epist. 41 contains a phrase that is extremely telling with regard to the profundity of Alcuin's political statement in these epistles concerned with the status of the Carolingians as Christian rulers. Alcuin writes: "Blessed is the nation, whose master is their God." ${ }^{\prime 199}$ This attribution makes the Carolingian 'state' meet Augustine's prime condition for being a godly 'state' on earth. It also takes the existence of indirect evidence of Augustinian influence in Alcuin's correspondence to a new level, as it now stands to reason that Alcuin has very well grasped the terms set by Augustine in the De civitate Dei that render a 'state' worldly or godly. Alcuin's goal is to show that the Carolingians are Christian rulers who are able to lead a people to the furthest extent possible under the divine commandments of the Christian God. Correspondingly, Alcuin maintains that the forms of iustitia ("justice") and pax ("peace") that exist in the Carolingian 'state' are not the worldly forms but are the justice and peace given to the Christian ruler and his Christian people by God. In Epist. 41, Charlemagne, just as David, who had been instituted by Christ as leader of the people of God, is said to be 
"a chosen preacher of the law of God." ${ }^{200}$ In Epist. 174 to Charlemagne (of early summer 799), Alcuin says to the ruler (who is addressed as King David): "You are the judge of the crimes, you are the guide of the erring" (Tu vindex scelerum, tu rector errantium). ${ }^{201}$

When looking at the occurrences of pax ("peace") independently, it emerges that there is again no doubt as to the quality of this concept; the peace within the Carolingian realm is the peace granted by the Christian God. The most striking reference to peace can be found in the first lines of Epist. 198, after Charlemagne is greeted as King David. ${ }^{202}$ There, Alcuin titles Charlemagne's 'state' perpetuae pacis civitas ("city of eternal peace"), which comes very close to a city of God realised on earth. Furthermore, Charlemagne's civitas is presented as superior to Jerusalem and the reign of the Old Testament kings, which are doomed to failure.

Alcuin reused Augustine to suit his own purpose. He availed himself of the ideas of iustitia ("justice") and pax ("peace") in his correspondence with Charlemagne and, in Epist. 41 and Epist. 229, alluded to Psalms 32 and 143 (including the verses Beata gens cuius est Dominus Deus eius and beatus populus cuius Dominus Deus eius), whose content Augustine had made the precondition for a civitas Dei. He concluded that, while even the Christian Roman emperors had not fully succeeded in meeting Augustine's challenge, Charlemagne was the first ruler capable of doing so, by leading a people perfectly under the command of the Christian God.

\section{Hincmar}

Devisse has dealt extensively with Hincmar's understanding of justice. He comprehends Hincmar's notion of "justice" (iustitia) as follows: Firstly, according to Hincmar, iustitia always belongs to God in the last instance. Secondly, iustitia is administered by means of "laws" (leges). Devisse recognizes three different kinds of "law" (lex) in Hincmar's oeuvre. ${ }^{203}$

The first one is the "law of God," which is the foundation of the other "laws." St. Paul refers to it as "enacted by angels and preached by a mediator ${ }^{204}$ due to transgressions." ${ }^{205}$ Devisse adds that the oldest representations of this "law" are, according to Augustine, the Decalogue and the Pentateuch. ${ }^{206}$

The second form is the "law" imparted by the Holy Spirit to the clergy assembled in 'church' councils. Hincmar's line of reasoning is that popes, because they decided alone and not in an assembly of judges, initially established a number of venerable, yet imperfect, rules. ${ }^{207}$ The ecumenical councils, whose ecclesiastical canons are directly inspired by the Holy Spirit, then perfected these earlier drafts, since the councils are intangible due to the presence of the Holy Spirit. ${ }^{208}$ However, a brief remark is in order regarding this second category of "law." Hincmar indeed uses the argument of the Holy Spirit taking part in councils in his Expositiones ad Carolum Regem in order to lay stress on the authority of the mentioned canon law enacted at certain named councils; ${ }^{209}$ but at the same time, in the De regis persona et regio ministerio, Hincmar asserts that the Holy Spirit speaks through the Holy Scriptures as well as through the Church Fathers, and therefore he will refer to 
these sources rather than write freely. ${ }^{210}$ This shows that it cannot be the case that Hincmar sees canon law as a separate category of "law," for the sole reason that he believes in the presence of the Holy Spirit at 'church' councils.

The third kind of "law," Devisse writes, is the "human law" (ius humane ${ }^{211}$ ) designed to govern human societies. It is envisaged by Hincmar - more than the other two forms of "law" - as an instrument for regulating the social life. ${ }^{212}$ Furthermore, Devisse says: “[ $\ldots$.$] c'est en ce sens, très souvent dans son oeuvre,$ pour ne pas dire exclusivement, que le prélat utilise le mot lex [...].”213 Devisse then expands on Hincmar's historical understanding of this legislation. In his outline, Devisse distinguishes between the "law" made by men before Christ (which naturally does not always have the "law of God" as its foundation), the civil "law" established by laymen in accordance with the teachings of Christ and the "law" of the 'church' (established through 'church' councils and decretals), which evolved as a legislation complementary to and at times overlapping with the civil "law." Devisse raises this difficulty of a shared responsibility. ${ }^{214}$ First, he says about the "law" of the "church": "La loi canonique a progressivement créé un domaine réservé où l'autorité civile ne doit ni juger ni pénétrer. Il n'y a cependant pas séparation radicale des deux mondes, l'un laïque, l'autre ecclésiastique, qui auraient, chacun, ses lois positives et qui n'obéiraient qu'à elles." ${ }^{215}$ Then he explains: "Si elles sont conformes au christianisme, les lois civiles s'imposent à tous, clercs et laïcs, au moins dans certaines de leurs prescriptions, dans tout le ressort politique où s'exerce leur autorité. La législation canonique s'adresse, par essence, essentiellement aux clercs. Mais elle déborde à son tour vers le monde des laïcs, quelle que soit leur origine. [...] Nul clerc cependant ne peut s'abriter derrière le droit canon, nul laïc derrière le droit civil pour échapper aux sanctions que permet de lui appliquer 'l'autre loi'."'216 Moreover, with regard to Hincmar's understanding of the civil "law," Devisse observes that, just as it was not ideal that the first popes established rules on their own, it is not advisable that kings make decisions alone, even though their authority over the civil "law" has never been contested. ${ }^{217}$ As stated by Devisse, Hincmar saw the notion of "justice" (iustitia) as composed of three different forms of "law" (lex). However, not least the finding that the argument of direct inspiration by the Holy Spirit is not unique to canon law calls for a reassessment of Hincmar's concept of "justice" (iustitia) and "law" (lex) - which, after all, may not be as complex as Devisse has conceived it.

CAP. XVIII. of the De regis persona et regio ministerio, where not only Augustine's but also Cicero's ideas of iustitia and misericordia are represented in a quote from the De civitate Dei, will provide further insight into how these authors imagined iustitia could best be implemented in a worldly 'state'. However, before scrutinising CAP. XVIII., the relation between iustitia and misericordia in Ciceronian thought, as well as the relevant chapter (Chapter 5 of Book IX) in the De civitate Dei, will be introduced. Cicero as a thinker was a follower of the New Academy. This is to say, he adhered to the Platonic principles but at the same time refused the possibility of recognising an absolute truth. ${ }^{218} \mathrm{He}$ tended towards Scepticism. As a philosopher, Cicero considered himself as a Stoic (like Seneca) or an Epicurean. Nevertheless, his way of seeking out the pros and cons - for 
instance of the different constituents of the doctrine of virtue - was unique. The concept of misericors/misericordia appears among the Stoics (including Seneca)

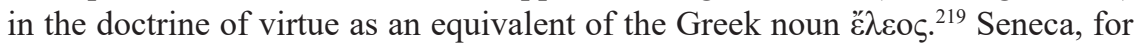
example, distinguishes between clementia and misericordia and regards the former as a minor, the latter as a major, vitium. His argument is that, just as severitas may degenerate into crudelitas, clementia may decline into misericordia. Misericordia is first and foremost condemnable for the reason that it is prompted by pity felt on account of another person's suffering without considering the cause of the person's suffering. Hence, there is an aspect of irrationality to misericordia. In contrast, Cicero described the misericordia of Caesar as one of the ruler's highest virtues. In the texts by Christian authors (including Augustine), misericordia then also features as a virtue. In the De civitate Dei, more precisely in Chapter 5 of Book IX, Augustine endorses Cicero's praise for Caesar's misericordia, contrary to the general belief of the Stoics. ${ }^{220}$ The chapter is concerned with the Christian doctrine of virtue imparted by the Holy Scriptures and explains that the Christians are not seduced into sinning by passions. The teachings of the Bible as rendered by Augustine resemble Cicero's model of a social order in which iustitia is implemented. It includes a God, who, being the supreme commander, rules over man, the human spirit that is in charge of the human body, and finally reason, which controls human desires to the benefit of men. In this chapter, Augustine relates Cicero's idea of the moderation of human emotions and passions to Christianity and its teachings. He evaluates the human emotion of misericordia in a Christian context while taking into account the views of Cicero and the Stoics. Augustine emphasises that the Christian doctrine of virtue contained in the Holy Scriptures teaches that within Christians the human desires (for instance misericordia) are curbed by the Christian God as the highest authority in a manner that they are subservient to iustitia. In other words, this suggests that a Christian ruler, due to his ability to control his emotions and passions, is able to govern a 'state' more justly than a non-Christian ruler. In this regard, Dodaro argues conclusively when he says that in the case of a Christian politician the four virtutes civiles are transformed beyond the fundamental level of virtue attained by a pagan secular leader and that, by allowing his conception of iustitia to be transformed by fides, spes and caritas, he punishes offenders with iustitia tempered with misericordia. A Christian ruler is capable of regulating his emotions in a way that they are useful to him in passing judgment. What Augustine writes next in Chapter 5 of Book IX (of the De civitate Dei) is quoted by Hincmar in CAP. XVIII. (of the De regis persona et regio ministerio). Augustine says that, according to Christian doctrine, having emotions per se is not necessarily an immoral act, but that the determining question is what these emotions are caused by. He carries on by claiming: "For to be angry with the sinner so that he may correct himself, to be sad on behalf of the miserable one so that he may be relieved, to fear for the endangered so that he may not perish, I do not know whether anyone would reprove that by rational consideration." 221 Then Augustine mentions the Stoics and Cicero. He observes that Cicero, contrary to the opinion of the Stoics, already recognised the virtuous quality of misericordia in his praise of Caesar. What follows is a key statement on 
which Hincmar ends his CAP. XVIII.: containing not only a definition of misericordia but also an explanation of the relation of misericordia and iustitia to one another. Augustine writes:

But what is forbearance if not compassion in our heart for a certain misery belonging to someone else, by which we are compelled to help by all means as much as we can? This emotion, namely, is in the service of reason if forbearance is granted to such an extent that justice is observed, be it when the one in need is endowed, or when the repentant is forgiven. ${ }^{222}$

The content of Augustine's statement is the following: when governed by reason, misericordia is correctly administered and can thus help bring about iustitia. But, according to Augustine, misericordia is only governed by a person's ration if his highest authority is the Christian God. After this passage, which is contained in Hincmar's CAP. XVIII., Augustine continues his argument in Chapter 5 of Book IX. He points out that Cicero's view of misericordia as a virtue is in fact not as opposed to that of the Stoics than generally presumed. He mentions the Stoic philosopher Epictetus who endorsed emotions such as misericordia in the wise men who are supposed to be free of vices. This shows, Augustine notes, that also the Stoics recognised human emotions as virtues if they occur in wise men in a manner that they neither affect the virtue of the mind nor reason. Here, Augustine's reasoning in the process of relating Ciceronian and Stoic philosophy to Christianity and its teachings is revealed: Augustine observes that already in Ciceronian and Stoic thought emotions were granted to the wise man, and he argues that it would therefore be even more justified to grant them to a Christian man. Emotions such as misericordia are better administered by a Christian - and best by the Christian God himself who is the only one capable of achieving vera iustitia. It can be seen that, according to Augustine, it is the most favourable situation for the implementation of iustitia on earth if the ruler is a Christian. This is moreover the reason why for Augustine misericordia is first and foremost an attribute of a Christian secular leader. Hence, Dodaro is right when he alleges that in the case of Christian secular authorities, Augustine considers iustitia to be transformed beyond the fundamental level of virtue, since Christian politicians alone are able to administer misericordia in a way that it benefits iustitia. The extract Hincmar quotes in CAP. XVIII. starts with the declaration that the Christian doctrine of virtue does not see emotions per se as immoral, because it primarily looks at their cause when evaluating their quality. Having thus established the virtuous quality of misericordia, Cicero's approval of the misericordia of the pagan Roman ruler Caesar is mentioned. What follows is a definition of misericordia and a clarification of the relation between iustitia and misericordia. Hincmar must have selected this passage in order to claim that the Christian moral code of secular leadership is superior to heathen political ethics. He differentiates between the vera iustitia of Christian rulers and the iustitia of pagan rulers. Unlike Augustine, who attributes a better administration of iustitia to rulers who are Christian but only attributes vera iustitia to 


\section{Hincmar of Rheims}

the Christian God, Hincmar does not differentiate between the Christian iustitia of Christian politicians and vera iustitia. The reason is that - as the analysis of separate chapters of the De regis persona et regio ministerio has exposed - in Hincmar's view iustitia is authorised by God and implemented by the ruler who gives laws on God's behalf. On this basis, Hincmar calls for their observance by everyone. While for Augustine it is impossible that everyone in a 'state' lives according to Cicero's and the Holy Scriptures' model of a social order in which iustitia is implemented, Hincmar does not call into question the realisability of this ideal in a 'state' as a whole. By choosing this extract from Chapter 5 of Book IX of the De civitate Dei, where misericordia features as an attribute of a secular leader (Caesar), Hincmar mainly considers the ruler's perspective. He does not refer to Augustine's argument in the De civitate Dei that in a social order misericordia can only be administered correctly - and hence bring about vera iustitia - if all members of the social order accept the Christian God as the highest authority.

\section{Notes}

1 On the chain of disputes concerning Hincmar of Laon, see West 2011, pp. 317-330. For an overview of the literature on Hincmar of Laon, see ibid., p. 318 (note 3); Patzold 2008, pp. 402-405.

2 The following information about the time of creation of the Expositiones ad Carolum Regem is taken from Devisse 1976, pp. 730-736. Devisse himself bases his argument on Amann.

3 Ibid., p. 730 (note 20).

4 Ibid.; Tavard 1973, p. 596.

5 Et requisito et non invento advocato illius, qui de eius capite ex praedicta causa redderet rationem, excepta ecclesia et episcopii domo, ac clericorum claustro, quidquid de rebus et facultatibus ecclesiasticis sibi in episcopali ordinatione munere Spiritus sancti ad gubernandum et dispensandum commissis acceperat, iussione vestra, per vicecomitem ipsius pagi, in bannum, quod ius lingua latina proscriptio confiscando vocatur, est missum. PL 125, col. 1037A-1037B.

6 Novum est enim quod nunc factum est, quia non est sub isto coelo auditum, ut episcopus cum Ecclesia sua proscriptionis titulo ab ullo religioso principe, laicorum iudicio, usque modo fuerit confiscatus, postquam Constantinus magnus imperator legem universis clericis dedit, dicens: "Constantinus clericis salutem dicit. Iuxta sanctionem quam dudum meruisse perhibemini, fundos et mancipia vestra nullus novis collationibus obligabit, sed vacatione gaudebitis." Cum enim dicit "nullus," nemo excipitur; verum in hac comprehensione etiam principalis potestas concluditur. Ibid., col. 1038C-1038D.

7 See the recent article by Schmitz 2015, pp. 127-152.

8 Ibid., col. 1052C.

9 See also Nelson 1986, pp. 135, 162.

10 Because the Quaterniones provide the author's own opinion, Hincmar defends the position he has taken so rigorously at the end of the text. PL 125, col. 1058C-1060A. (This will be explored in detail further below.)

11 Deinde iussistis praefatum episcopum, ut die et loco denominato veniret ad causas vestras, id est, ad saecularia iudicia, et suum advocatum de suo capite, videlicet de suo quod ipse egit actu, id est, non conscio quocunque coepiscopo suo, donaret. Qui mittens ad dominationem vestram, excusationem impossibilitatis suae illuc veniendi 
mandavit. Requisita est quam patriotica lingua nominamus exonia, quia venire nequiverit: quod hactenus est inauditum. Ibid., col. 1037A.

12 Et licet credendum sit de vestrae christianitatis religione, quoniam ad ipsius correctionem episcopi hoc egeritis; tamen miranda est vestra sapientia, quae sic medicamentum illius vulneri temperavit, ut de medicamento ipsa vulneraretur: cum Dominus mensuram in proximi dilectione talem ponat, ut proximum sicut nos ipsos, et non plus nos ipsos diligamus. Fama enim, quin potius infamia haec, Burgundiam et Provinciam, atque Italiam penetrans, Romam perveniet; et per regnum nepotis vestri, non solum usque ad citeriorem, verum et usque Germaniam ulteriorem perveniet, Aquitaniam et Septimaniam per Neustriam volitans occupabit. Et quis oculum simplicem, id est, rectam intentionem, quam in vobis nescit, putabit: ubi factum Domino contrarium, et inimicum sacris canonibus, sicut beatus Leo scribit, Spiritu Dei conditis et totius mundi reverentia consecratis, quorum conditores in coelo cum Domino regnantes, et in terris miraculis coruscantes, adhuc nobiscum in constitutionibus vivunt; sed et legibus, quibus una cum eisdem sacris canonibus moderatur Ecclesia, constat adversum? Ibid., col. 1037C-1038A.

13 Ibid., col. 1038D.

14 Ibid., col. 1038D-1039A.

15 Quaecunque, inquiunt, a parentibus nostris diversis sunt statuta temporibus, manere inviolata atque incorrupta circa sanctas Ecclesias praecipimus. Ibid., col. 1039A.

16 Civ. V 24, pp. 236-237.

17 Civ. V 19, p. 230.

18 Civ. V 26, pp. 239-240.

19 On the historical context of Ambrose's intervention against Theodosius I, see Young 2010, pp. 658-659; Markus 1988, pp. 94-96.

20 Quid autem fuit eius religiosa humilitate mirabilius, quando in thessalonicensium gravissimum scelus, cui iam episcopis intercedentibus promiserat indulgentiam, tumultu quorundam, qui ei cohaerebant, vindicare compulsus est et ecclesiastica cohercitus disciplina sic egit paenitentiam, ut imperatoriam celsitudinem pro illo populus orans magis fleret videndo prostratam, quam peccando timeret iratam?

Haec ille secum et si qua similia, quae commemorare longum est, bona opera tulit ex isto temporali vapore cuiuslibet culminis et sublimitatis humanae; quorum operum merces est aeterna felicitas, cuius dator est Deus solis veraciter piis. Civ. V 26, p. 240, 11. 16-27.

21 Multa etiam hic poni poterant, quae ab omnibus salubriter regnantibus, et iuste iudicantibus longo tempore conservata sunt; sed scio sapientiam vestram ex his quae de decimo sexto libro Theodosianae legis sunt posita, debere comprehendere plura. PL 125, col. 1039D. J. M. Wallace-Hadrill is right that Charles the Bald was familiar with the Codex Theodosianus. Wallace-Hadrill 1975, p. 195.

22 PL 125, col. 1040A-1040B.

23 The liber Capitulorum imperalium, cap. 67 cited by Hincmar is a reference to the Collectio capitularium Ansegisi, cap. 77, which supposedly collected Charlemagne's capitularies on ecclesiastical law. Cap. Ansegisi, p. 475, lin. 13-p. 477, lin. 5. However, this capitulary is from the Capitulare ecclesiasticum, which was issued by Louis the Pious (not by Charlemagne). Cap. Hludowici Pii, p. 275, lin. 37-p. 276, lin. 1.

24 Et horum imperatorum imitantes religionem antiqui etiam et moderni reges Francorum, immunitates ecclesiis et servis Dei facere consueverunt, quas qui non servant, de illorum eleemosyna peccata sua accumulant. Itaque cum de aliis memorabilibus imperatoribus ac regibus loquimur, avi vestri, magni imperatoris Caroli non est praetereunda memoria. Cui cum, sicut assolet, adulantium linguis subreptam fuerit, ut ecclesiis de rebus suis praeiudicium quoddam inferret; obsistentibus episcopis, et specialiter Paulino patriarcha, sicut vobis bene notum esse cognosco, adeo se recognovit, et ecclesiae ac episcopis satisfecit; ut praesens oris sui confessio ei non 


\section{Hincmar of Rheims}

suffecerit, sed ad posteros suos, qui ex illius progenie exorturi erant, confessionis et correctionis suae scriptum manu sua firmatum transmiserit. De quo edicto partem in libro vestro, qui appellatur liber Capitulorum imperalium, scriptum habetur, cap. 67 ubi scriptum est: "Quia iuxta sanctorum Patrum traditionem novimus res Ecclesiae vota esse fidelium, pretia peccatorum, et patrimonia pauperum: cuique non solum habita conservare, verum etiam multa Deo opitulante conferre optamus: tamen ut ab ecclesiasticis de non dividendis rebus illius suspicionem dudum conceptam penitus amoveremus, statuimus, ut neque nostris, neque filiorum, et Deo dispensante, successorum nostrorum temporibus, qui nostram vel progenitorum voluntatem, vel exemplum imitari voluerint, ullam penitus divisionem aut iacturam patiatur.” PL 125, col. 1039D-1040B.

25 Ibid., col. 1040B.

26 It will be seen that later in the Quaterniones, King David (with reference to Bathsheba: 2 Sam 11:1-12:25) and Theodosius I are presented as sinners. (The Old Testament episode of David's seduction of Bathsheba is also illustrated in an ivory carving at the centre of the jewelled back cover of Charles the Bald's Psalter. Nees 1995, pp. 202-212.)

27 See Wallace-Hadrill's discussions in support of this argument. Wallace-Hadrill 1971, p. 103; Wallace-Hadrill 1975, pp. 189, 193.

28 This is in line with H. H. Anton's argument that Hincmar avoids deriving any royal inviolability from such Bible quotations. Anton 1968, pp. 290-291.

29 Quod licet non fiat, sicut saepe solet accidere, in oculis hominum, fit tamen semper in oculis Domini. Sed sicut superbiendo David: Quia initium omnis peccati superbia faciens contra professionem suam, quam professus est, dicens: Vivit Dominus, quia ludam ante Dominum, et ero humilis in oculis meis prophetiae gratiam et dignitatem regiam, quam peccando perdidit, confessus coram Nathan poenitendo recuperavit. PL 125, col. 1040D-1041A.

30 Ibid., col. 1041B-1042D.

31 Ibid., col. 1042C.

32 Ibid., col. 1042D-1043C.

33 Ibid., col. 1043D-1044B.

34 Sed et Antiocheni canones, ita inde praecipiunt: "Quae sunt ecclesiae, sub omni sollicitudine et conscientia bona, et fide quae in Deum est, qui cuncta considerat iudicatque, serventur: quae etiam dispensanda sunt iudicio et potestate pontificis, cui commissus est populus, et animae quae intra ecclesiam congregantur." Et item: "Episcopus ecclesiasticarum rerum habeat potestatem ad dispensandum erga omnes qui indigent, cum summa reverentia et timore Dei. Participet autem et ipse quibus indiget, si tamen indiget, tam suis, quam fratrum qui ab eo suscipiuntur, necessariis usibus profuturis." Ibid., col. 1043D-1044A.

35 Ibid., col. 1045B-1045C.

36 Ibid., col. 1045C-1045D.

37 Ibid., col. 1045C-1049B.

38 Regarding property law and Christian doctrine, see H. Chadwick's reference to Augustine. Chadwick 1988, p. 14.

39 In the Quaterniones, Hincmar quotes the same passages from Augustine's Sermo Ioannis Evangelii that he quoted in Epist. 108 (in the foreword to his Collectio de ecclesiis et capellis) between 857 and the spring of 858 .

40 PL 125, col. 1052B.

41 Unde legalis sententia, quam ut praedecessores illius, B. Gregorius in commonitorio Ioanni dato decrevit esse canonicam, dicit: "Necesse est ut quod contra leges est actum firmitatem non habeat." Ibid., col. 1055C.

42 "In istis temporalibus legibus quanquam de his homines iudicent, cum eas instituunt; tamen cum fuerint institutae atque firmatae non licebit iudici de ipsis iudicare, 
sed secundum ipsas. Conditor tamen legum temporalium si vir bonus et sapiens est, illam ipsam consulit aeternam, de qua nulli animae iudicare datum est, ut secundum eius incommutabiles regulas quid sit pro tempore iubendum vetandumque discernat. Aeternam igitur legem mundis animis fas est cognoscere, nefas est iudicare." Ibid., col. 1055C-1055D.

43 Drawn from Epigrammata ex sententiis Augustini, XLI. De providentia Dei. PL 51, col. 0510C.

44 Pope Leo I (the Great) (440-461).

45 Nam si imperatores Romanorum suam legem aeternam, vel perpetuam appellaverunt, multo magis lex illa aeterna est, quae est sancto Spiritu promulgata. De qua S. Leo post discretionem quae in ea est ostensam dicit: "In his quae vel dubia fuerint, vel obscura, id novimus sequendum, quod nec praeceptis evangelicis contrarium, nec decretis sanctorum inveniatur adversum." PL 125, col. 1055D.

$461 \mathrm{Kgs} 2$.

47 Et in sacra Regum historia scriptum est: Si peccaverit vir in virum, placari ei potest Dominus: si autem in Domino peccaverit vir, quis orabit pro eo? Mementote facti memorandi Theodosii, et memorabilis viri Ambrosii, et quia excessit ut homo Theodosius, corripuit eum ut verus sacerdos Ambrosius, et recepit patienter atque humiliter per illum divinam correctionem Theodosius. Et ideo exaltatus est, et merito et nomine, et sanctitatis insigne super omnes post Constantinum Romanos imperatores. Felix ille imperator qui suo tempore talem habuit sacerdotem, qui post dignam pro excessu satisfactionem fecit illi ponere, et confirmare legem, ut si moto animo severius vindicare in aliquos princeps quisque decerneret, ministri reipublicae usque ad triginta dies eamdem legem exsequi non auderent, donec refrigerato animo, et in se reverso, quid verum esset, videret, et exsequi quod iustum esset, decerneret. Nam impedit ira virum ne possit cernere verum, quia, ut quidam sapiens dixit, cogitationes iracundi vipereae sunt generationis; prius enim mentem comedunt, matrem suam. Et Apostolus: Ira, inquit, viri iustitiam Dei non operatur. Et felix sacerdos Dei Ambrosius, qui in tempore talis fuit imperatoris. Scriptum est enim: Beatus qui enarrat iustitiam auri audienti. Felices quoque ambo, et sacerdos et imperator. Quia ne ira Dei pro excessu descenderet super imperatorem, habuit suo tempore sacerdotem, de quo non questus est Dominus [...]. PL 125, col. 1056C-1057A.

48 By 'Augustinian', I refer to the thought that is manifested in Augustine's later work in particular, the De civitate Dei.

49 This is not the only instance where Hincmar associates the Frankish episcopal authority with Bishop Ambrose. See De Jong 2009, pp. 267-268.

50 PL 125, col. 1056C-1056D.

51 Ibid., col. 1058C-1059B.

521 Cor 11.

532 Kgs 14-15, 2 Chr 26.

54 Mt 10:20.

551 Cor 5:11.

56 Acts 10:34.

57 Eph 5:11.

58 In quo facto, quia sicut Scriptura dicit: Haec autem in figura contingebant illis, scripta sunt autem propter nos, diligenter attendendum est quandiu Ozias Dominum coluit, pacifice regnum tenuit, et contra vicinas et alienigenas gentes crebras victorias habuit. Postquam autem officium non suum praesumpsit, sed in sacerdotale ministerium contra fas manum praesumptionis extendit, usque ad diem mortis suae lepra plenus in domo separata permansit, et victoriam nullam fecit: nec cum aliis qui bellabant bella Domini pro inimicis Israel, qui Ecclesiae typum tenuerat, perfusus lepra, id est, gravi peccato percussus atque perculsus habitare praevaluit. Sic et eorum iudicio quibus dicit Dominus: Non vos estis qui loquimini, sed Spiritus Patris vestri qui loquitur in 


\section{Hincmar of Rheims}

vobis, et per quos eodem Spiritu sacri promulgati sunt canones; voluntarie atque ex deliberatione quiscunque violans et convellens constituta divina, quia docente Petro, Non est personarum acceptor Deus, ab Ecclesiae corpore separatus, nisi per poenitentiam et sacerdotalis indulgentiae reconciliationem eidem Ecclesiae fuerit reincorporatus, erit ab aeterna Ecclesia separatus. Unde et Apostolus praecipit, Cum huiusmodi nec cibum sumere. Et item omnibus, Christo in se loquente, denuntiat dicens: Nolite communicare operibus infructuosis tenebrarum. Quam sententiam exponens beatus Augustinus, dicit: "Duobus modis non te maculat malus: si non consentias, et si redarguas; hoc est non communicare, non consentire. Communicatur quippe, quando facto eius consortium voluntatis vel approbationis adiungitur. Hoc ergo nos admonens Apostolus, ait: Nolite communicare operibus infructuosis tenebrarum. Et quia parum non erat consentire, si sequeretur negligentia disciplinae, magis autem, inquit, et redarguite. Videte quemadmodum utrumque complexus est: nolite communicare: nolite consentire, nolite laudare, nolite approbare. Quid est autem, magis et redarguite? Reprehendite, corripite, coercete. Deinde in ipsa reprehensione vel coercitione aliorum peccatorum, cavendum est ne se extollat qui alterum corripit; et qui se putat stare, videat ne cadat; foris terribiliter personet increpatio, intus lenitatis teneatur dilectio. Neque ergo consentientes sitis malis, ut approbetis; neque negligentes, ut non arguatis; neque superbientes, ut insultanter arguatis." PL 125, col. 1058C-1059B.

59 Ibid., col. 1059C-1060A.

60 Ps 69:10.

612 Mc 6-7.

$62 \operatorname{Prv} 27: 6$.

63 Jn 8:32.

64 Et nolite putare, domine charissime ac benignissime, quia quocunque carnalis propinquitatis affectu, vel quia tantum in episcopo Rhemensis provinciae indignitati meae commissae ista sunt acta, commotus haec scripserim; sed zelo, de quo et in psalmo et in Evangelio scriptum est: Zelus domus tuae comedit me, videlicet zelo universalis Ecclesiae, quae domus Dei est, et sacri ordinis sacerdotalis, quod unum in omnibus episcopis est, et officii meae exiguitatis, legens electos Dei propter leges paternas, etiam mortem corporis appetisse, et in laudibus divinis Ecclesiam catholicam cantare sanctum: Qui pro lege Dei sui certavit usque ad mortem. Vestrae nihilominus zelo salutis et optandae nobis prosperitatis haec scripsi. Tandem peto ut in hoc servitutis meae obsequio diligentius discernatis, quoniam si quaedam ibidem mordacius resonant, non mihi verba sunt sensus: quae etsi forent, mansuetudo vestra debet modeste perpendere, quoniam adulator blandus est inimicus. Quod Scriptura dicit: Quia meliora sunt vulnera amici, quam odientis inimici oscula. Non enim occupatam tenet vestram, sicut quorumdam captivatam mentem possidet vobis bene noti sententia, quae dicit: obsequium, id est, assentatio, videlicet adulatio, amicos, veritas odium parit: quia, ut veritatis amicus veritatem diligitis, scientes a Veritate dictum: Cognoscetis veritatem, et veritas liberabit vos. Inhaereat itaque menti vestrae quod beatus Augustinus dicit, quia dolosi vel imperiti medici est, sic vulneri emplastrum imponere, ut aut noceat, aut non prosit. Et supra posita quae sine adulatione ad vestram salutem veritas per ora veridicorum protulit, vobis non displicebunt. PL 125, col. 1059C-1060A.

65 On the genre, see Stone 2012, pp. 42-46.

66 Devisse 1976, p. 710.

67 Ibid., p. 710 (in note 225, the dating of the De regis persona et regio ministerio is discussed).

68 Schrörs 1884, p. 385 (in note 26, Schrörs on his part bases his argument on that of C. F. J. von Noorden).

69 For further details, see De Jong 2009, pp. 264ff.

70 Schrörs 1884, p. 385. 
71 Devisse 1976, p. 710 (note 225).

72 Ibid., pp. 714-717.

73 Ibid., p. 561; Ganz 1990, p. 285, 297, 300.

74 Ganz 1990, p. 285.

75 Ibid.

76 Ibid., pp. 297, 300.

77 See Wallace-Hadrill 1971, p. 125; Wallace-Hadrill 1975, p. 196; Nelson 1986, pp. 164-165, 167.

78 The doctrine of "double predestination," "two-fold predestination" or "absolute predestination" refers to a belief in predestination to salvation as well as predestination to condemnation. The most important doctrinal questions relating to the debate over predestination are outlined in Ganz 1990; Marenbon 1990.

79 Ganz 1990, pp. 286-287.

80 Heidecker 2010, pp. 51ff., 54, 64ff.

81 Ibid., p. 43.

82 Ibid., pp. 100-104.

83 Ibid., p. 109.

84 On Hincmar's treatise, see ibid., pp. 46ff.

85 On the case of Rothad of Soissons, see Nelson 1986, pp. 157ff.

86 PL 125, col. 1222C.

87 Tavard 1973, p. 596.

88 Devisse 1976, pp. 714-717.

89 Domino glorioso fideliter devotus et devote fidelis.

Obaudientes praeceptum Domini per prophetam iubentis, Interroga sacerdotes legem meam (Agg. II, 12), super quibusdam capitulis me consulere vobis placuit. De quibus quoniam per se Veritas dicit, Qui a semetipso loquitur, gloriam propriam quaerit (Joan. VII, 18), dignum duxi non nudo meo sermone vobis respondere, sed quid in Scripturis sacris et per catholicos doctores inde loquatur Spiritus sanctus, quosdam odoriferos flosculos, ut revera de agro pleno, Scripturarum scilicet campo, cui benedixit Dominus, breviter in unum vobis colligere. Et sciens pollicitum, Quod supererogaveris, ego cum rediero reddam tibi (Luc. X, 15), de his quae regio ministerio vobis a Deo commisso competere vidi, quasi scintillas micantes lumini scientiae vestrae superadieci. Quia vero, ut Comicus dicit (Ter. in Andr.):

Obsequium amicos, veritas odium parit,

et non assentatio, videlicet adulatio, principi ac domino terrae placere debet, minime autem sacerdotem sectari eam oportet, si quiddam mordacius dictum in sententiis a me collectis de regis persona et regio ministerio inveneritis, non contra vos, quaeso, sed pro vobis eas me collegisse putetis, quoniam aut talem in benignitate ac bonitate, sicut ipsae describunt sententiae, vos esse et sic agere scio, aut talem esse et sic agere cupio. Huius autem libelli sententiae triformi sunt collectione distinctae. Primo quidem de persona regis et regio ministerio in generali reipublicae causa. Deinde quae debeat esse discretio in misericordia, et de ultione specialium personarum, quae si exitialiter agentes aliter non potuerint corrigi, temporali morte praecipiuntur multari, quod a quibusdam dicitur contradici. Tum quia rex propter ministerium regium, etiam nec quibuscunque propinquitatis necessitudinibus, contra Deum sanctamque Ecclesiam atque contra rempublicam agentibus criminaliter, affectu carnali parcere debeat. PL 125, col. 0833B-0834B.

90 Anton righty sees in these capitula on the duties of the Christian ruler, a culmination of the "political Augustinianism" in the ninth century. Anton 1968, pp. 230-231.

91 Devisse 1976, pp. 710-713.

92 Ibid., p. 711. This view was already taken by Anton. See the scholarly debate in Anton 1968, pp. 225, 230-231, $286 \mathrm{ff}$.

93 Devisse 1976, pp. 712-713. 


\section{Hincmar of Rheims}

94 The authors' works will not be mentioned, although quotations from Augustine's De civitate Dei will be indicated. Quotations of the Scriptures will not be referred to at this point.

95 AL vol. 3 2004-2010, p. 879.

96 Nihil fit nisi quod aut Deus facit, aut fieri iuste permittit [...]. PL 125, col. 0834B.

97 See also Nelson 1986, p. 138.

98 ... Deus ver[us], qui dat felicitatem in regno caelorum solis piis; regnum vero terrenum et piis et impiis, sicut ei placet, cui nihil iniuste placet. Civ. V 21, p. 232, 11. $25-27$.

99 Haec plane Deus unus et verus regit et gubernat, ut placet; et si occultis causis, numquid iniustis? Ibid., p. 233, 11. 25-27.

100 [...] occulto Dei iudicio, sed tamen iusto. Civ. XII 28, p. 556, 11. 15-16.

101 AL vol. 3 2004-2010, pp. 870-871, 877-878.

102 Et ideo regna terrena et bonis ab illo dantur et malis, ne eius cultores adhuc in provectu animi parvuli haec ab eo munera quasi magnum aliquid concupiscant. Civ. IV 33, p. 188, 11. 15-18.

103 See "The Imperial Title and the Problem of Political Unity" in the ninth century by Meens 2007, pp. 498-505.

104 Nelson 1994, pp. 71-72. See also her French publication, Nelson 2011, pp. 241-254.

105 Ibid., p. 64.

106 Devisse 1976, p. 673.

107 Ibid., p. 674.

108 Nelson 1996, p. 92.

109 Ibid., pp. 92-93.

110 Nelson 1994, p. 69; Nelson 1996, p. 93.

111 Civ. V 26, pp. 238-242.

112 Civ. IV 3-4, pp. 149-150.

113 Civ. IV 3, p. 150, 11. 4-5.

114 Remota itaque iustitia quid sunt regna nisi magna latrocinia? Civ. IV 4, p. 150, 11. 19-20.

115 On Hincmar's use of Augustine in his discourse on justice, see Anton 1968, p. 301.

116 This corresponds to ibid., pp. 285ff.; Wallace-Hadrill 1975, pp. 192-195; Devisse 1976, pp. 696-697; Markus 1988, pp. 95-102. Nelson relates the distinction between person and office to Augustine. Nelson 1986, pp. 134-135.

117 This important point is made clear by Devisse 1976, pp. 705-707; Wallace-Hadrill 1971, pp. 127-128; Wallace-Hadrill 1975, pp. 184-185, 195-197; Nelson 1986, pp. 134f.

118 Devisse 1976, pp. 696-697.

119 Nelson 1986, p. 139.

120 Hincmar's extensive treatment of pax ("peace") is summarised in Kershaw 2011, pp. 221-223.

$121[\ldots]$ belligerare, et perdomitis gentibus dilatare regnum, malis videtur felicitas, bonis necessitas. Civ. IV 15, p. 164, 11. 26-27. See also the brief discussion in Kershaw 2011, pp. 222-223.

122 Sed quia peius esset, ut iniuriosi iustioribus dominarentur, ideo non incongrue dicitur etiam ista felicitas. Civ. IV 15, p. 164, 11. 27-29.

123 Ibid., p. 164, 11. 29-31.

124 Ibid., p. 164.

125 For details on Augustine's morality of warfare, see Markus 1988, pp. 115-116. Although Augustine never developed systematic rules for the conditions under which wars might be just, I concur with Markus, who states: "It is clear from his [Augustine's] scattered statements that relatively few wars, especially few wars which were not defensive, would have qualified." Ibid., p. 115. 
126 Bellum necessitas faciat, ut, sopita discordia, pax recuperari possit. PL 125, col. 0841A.

127 Civ. V 24, pp. 236-237, V 25, pp. 237-238.

128 Civ. IV 33, p. 188.

129 On Hincmar's use of this extract in the De regis persona et regio ministerio, see also Kershaw 2011, pp. 222-223.

130 Fides enim quando promittitur, etiam hosti servanda est contra quem bellum geritur, quanto magis amico pro quo pugnatur? Pacem habere debet voluntas, bellum necessitas, ut liberet Deus a necessitate, et conservet in pace. Non enim pax quaeritur ut bellum excitetur, sed bellum geritur ut pax acquiratur. Esto ergo etiam bellando pacificus, ut eos quos expugnas ad pacis utilitatem vincendo perducas. Beati enim pacifici, ait Dominus, quoniam filii Dei vocabuntur. PL 125, col. 0842B.

131 Civ. IX 13, pp. 384-386.

132 Ipsa est autem illa daemonum misera aeternitas vel aeterna miseria. Ibid., p. 385, 11. $22-23$.

$133 \mathrm{Si}$ igitur beati recte dicuntur eudaemones, non sunt eudaemones daemones, quos inter homines et deos isti in medio locaverunt. Ibid., p. 385, 11. 28-30.

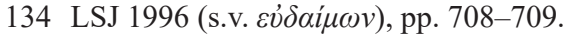

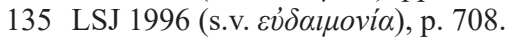

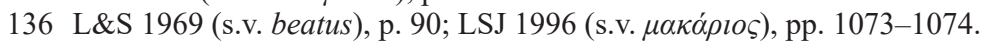

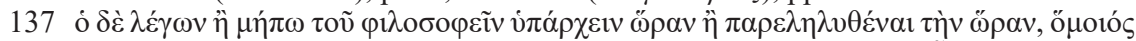

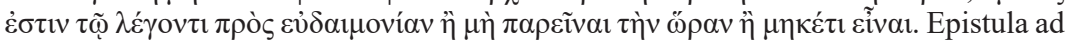
Menoeceum, 122.

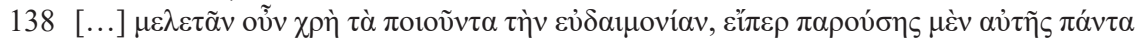

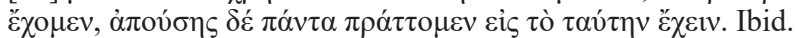

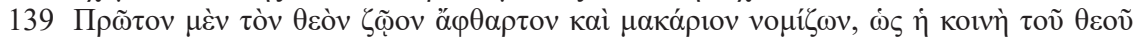

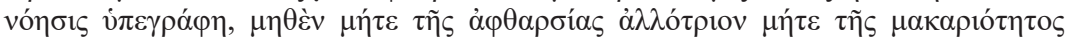

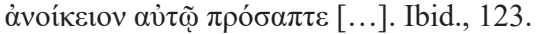

140 Civ. IX 13, pp. 384-386.

141 AL vol. 3 2004-2010, p. 140.

142 PL 125, col. 0839B.

$143 \mathrm{Si}$ adiuves eum qui adversus viduam et pupillos gravi decernit iurgio, aut vi aliqua possessiones eorum eripere conatur, non probatur largitas, si quod alteri largitur, alteri quis extorqueat, si iniuste quaerat, et iuste dispensandum putet: nisi forte, ut ille Zachaeus (Luc. XIX), reddas prius ei quadruplum quem fraudaveris, et gentilitatis vitia fidei studio, et credentis operatione compenses. Ibid.

144 AL vol. 3 2004-2010, pp. 878-879.

$145[\ldots]$ et ideo nequaquam contra hoc praeceptum fecerunt, quo dictum est: Non occides, qui Deo auctore bella gesserunt, aut personam gerentes publicae potestatis, secundum eius leges, hoc est iustissimae rationis imperium, sceleratos morte punierunt. PL 125, col. 0841B.

146 His igitur exceptis, quos vel lex iusta generaliter, vel ipse fons iustitiae Deus specialiter occidi iubet, quisquis hominem, vel seipsum, vel quemlibet occiderit, homicidii crimine tenetur. Ibid., col. $0841 \mathrm{C}$.

147 AL vol. 3 2004-2010, p. 876.

148 Ibid.

149 Hom. 32.

150 Cui ergo licite ignoscere liceat principi vel iudici, sub iusto et misericordi iudice, qui convertenti et poenitenti ignoscit, beatus Gregorius in homilia Evangelii demonstrat. PL 125, col. 0847A.

151 Sent. 210.

152 "Peccata, sive parva, sive magna, impunita esse non possunt, quia aut homine poenitente, aut Deo iudicante plectuntur. Cessat autem vindicta divina, si conversio 


\section{Hincmar of Rheims}

praecurrat humana. Amat enim Deus confitentibus parcere, et eos qui semetipsos iudicant non iudicare." PL 125, col. 0847D.

153 Ibid., col. 1055C-1055D.

154 AL vol. 3 2004-2010, p. 878.

155 Ibid., pp. 878-879.

156 'Est igitur' inquit Africanus 'res publica res populi; populus autem non omnis hominum coetus quoquo modo congregatus, sed coetus multitudinis iuris consensus et utilitatis communione sociatus. Eius autem prima causa coeundi est non tam imbecillitas, quam naturalis quaedam hominum quasi congregatio. ...' Rep. I 39, p. 28; see also Civ. II 21, p. 81.

157 Ibid.

158 Ibid., pp. 79, 81-82.

159 Ibid., pp. 80-81, XIX 21, pp. 390-391.

160 Civ. XIX 21, p. 391.

161 Ibid., XIX 23, p. 399.

162 Civ. II 21, p. 83.

163 Civ. XIX 24.

164 Ibid., p. 400.

165 Ibid., p. 400, 11. 6-7.

166 Civ. II 21, p. 81.

167 Civ. XIX 24, p. 400.

168 Ibid.

169 Ibid., pp. 400-401.

170 Civ. XIX 24.

171 Ibid., p. 400.

172 Civ. XVIII 2, pp. 256-259, 22, p. 284, 27, p. 292, V 13, p. 217, 21, pp. 232-233, IV 6-7, pp. 152-154.

173 Civ. XVIII 2, pp. 256-259, 22, p. 284, 27, p. 292, V 13, p. 217, IV 6-7, pp. 152-154.

174 Civ. V 19, p. 230.

175 Civ. XVIII 1, pp. 255-256, 2, p. 259.

176 Civ. XVIII 2, p. 256, 22, p. 284, XV 4, p. 63.

177 Civ. XVIII 2, p. 257, 3, pp. 259-260.

178 Civ. XVIII 27, p. 292.

179 Civ. V 25, 26.

180 Dvornik 1966, p. 849.

181 Ibid., p. 841; Chadwick 1988, pp. 12-13. On the Carolingians see the discussions in Wallace-Hadrill 1971, pp. 127-128; Wallace-Hadrill 1975, pp. 193-195.

182 Dvornik 1966, pp. 846-847.

183 AL vol. 3 2004-2010, p. 879.

184 On Augustine's concept of iustitia in the De civitate Dei, see also Dodaro 1999, pp. 181-183; Markus 1970, pp. 64f., 99f., 208; Wilks 1967, pp. 496-499; Baynes 1936, pp. 16-17. The concept of pax is discussed by Schofield 2010, pp. 667-671; Martin 1972, p. 214ff.; Markus 1970, pp. 68f., 83f., 95f.

185 Dvornik defines the natural pax as "natural mutual accord" in human society. Dvornik 1966, p. 846.

186 Arquillière states that Augustine's divine iustitia basically corresponds to St. Paul's evangelical justice. He claims, however, that Augustine was the first to apply it to the constitution of 'states'. Arquillière 1934, p. 21.

187 Dvornik's translation of Augustine's definition of divine pax in Chapter 13 of Book XIX of the De civitate Dei is: "The peace of the heavenly city is a perfectly ordered and fully concordant fellowship in the enjoyment of God and in mutual enjoyment by union with God; the peace of all things is a tranquillity of order." Dvornik 1966, p. 845.

188 Arquillière 1934, pp. 151f. 
189 Dvornik 1966, p. 848.

190 Arquillière 1934, p. 152.

191 His argument is supported by Wallace-Hadrill 1971, p. 103; Wallace-Hadrill 1975, pp. 189, 193.

192 Arquillière 1934, p. 128.

193 Ibid., p. 131.

194 Epist. 41, pp. 84-85.

195 At the beginning of Epist. 148 in his address to Charlemagne, who is referred to as King David, Alcuin also presents the king as chosen and loved by God. Epist. 148, pp. 237-241.

196 Epist. 217, pp. 360-361.

197 Epist. 177, pp. 292-293.

198 Civ. XIX 21, p. 391, XIX 23, p. 399.

199 Beata gens, cuius est dominus Deus eorum. Epist. 41, p. 84, lin. 12.

200 Ibid., p. 84, lin. 14.

201 Epist. 174, pp. 288-289.

202 Epist. 198, p. 327, lin. 2.

203 Devisse 1976, pp. 549-564.

204 Moses takes the role of a mediator.

205 Gal 3:19. See Devisse 1976, p. 550.

206 Enarrationes in Psalmos LVII I. See ibid.

207 Hincmar's argument for the superiority of the many in judgment is remarkable in this context. His line of thought is surely influenced by Aristotle's summation argument

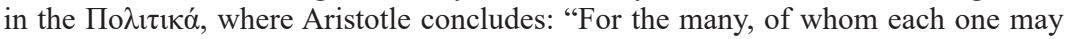
not be an excellent man, it is nevertheless possible that when they have come together they are better than those [few best], not as each one but as all together [...]. For when there are many, each one has a small piece of excellency and prudence, and when they have come together they may become just like one person [...]. Therefore, the many

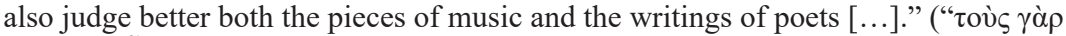

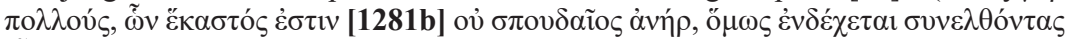

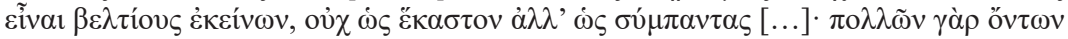

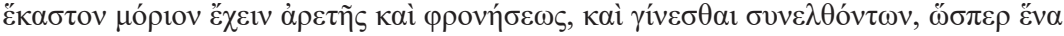

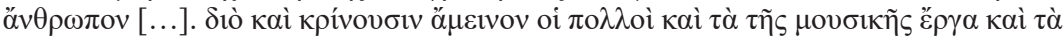
$\tau \tilde{\omega} \nu \pi \mathrm{o} \eta \tau \tilde{\omega} \nu[\ldots] . ")$

208 Devisse 1976, pp. 552-553.

209 PL 125, col. 1038A, 1040D, 1044B, 1058D-1059A.

210 Ibid., col. 0833B.

211 Ibid., col. 1051B.

212 Devisse 1976, p. 551.

213 Ibid.

214 Ibid.

215 Ibid., pp. 551-552.

216 Ibid., p. 554.

217 Ibid.

218 See Atkins 2010, pp. 503-504.

219 AL vol. 4, 1/2 2010-2013, p. 34.

220 Civ. IX 5, pp. 374-376.

221 Irasci enim peccanti ut corrigatur, contristari pro adflicto ut liberetur, timere periclitanti ne pereat nescio utrum quisquam sana consideratione reprehendat. Ibid., p. 375, 11. 4-7.

222 Quid est autem misericordia nisi alienae miseriae quaedam in nostro corde compassio, qua utique si possumus subvenire compellimur? Servit autem motus iste rationi, quando ita praebetur misericordia, ut iustitia conservetur, sive cum indigenti tribuitur, sive cum ignoscitur paenitenti. Ibid., p. 375, 11. 13-18. 


\section{Bibliography}

\section{Primary sources}

Alcuinus: Epistolae. Ernst Dümmler (ed.) (MGH Epp. 4). Berlin, 1895.

Collectio capitularium Ansegisi. Gerhard Schmitz (ed.) (MGH Capit. N. S. 1). 1996, 431-681.

Augustinus Hipponensis: Sancti Aurelii Augustini episcopi De civitate Dei libri XXll 2 vols. Bernhard Dombart et Alfons Kalb (recogn.). (5th ed.). Stuttgart, 1993.

Epicuri epistulae tres et ratae sententiae a Laertio Diogene servitatae. Peter von der Muehll (ed.) (accedit Gnomologium Epicureum Vaticanum). Stuttgart, 1975 [1922].

Hludowici Pii capitularia. Alfred Boretius (ed.) (MGH Capit. 1). 1883, 261-315.

Marcus Tullius Cicero: De re publica; De legibus; Cato maior de senectute; Laelius de amicitia. J. G. F. Powell (recogn. brevique adnotatione critica instruxit). Oxford and New York, 2006.

\section{Secondary sources}

Anton, Hans, Hubert: Fürstenspiegel und Herrscherethos in der Karolingerzeit. Bonn, 1968.

Arquillière, H.-X.: L'Augustinisme politique: Essai sur la formation des théories politiques du Moyen-Âge. Paris, 1934.

Atkins, E. Margaret: Cicero, in: Christopher Rowe and Malcolm Schofield (eds.): The Cambridge History of Greek and Roman Political Thought. (5th printing). Cambridge, 2010, 477-516.

Baynes, Norman Hepburn: The Political Ideas of St. Augustine's De Civitate Dei. Historical Association Pamphlet 104, 1936, 3-18.

Chadwick, Henry: Christian Doctrine, in: James Henderson Burns (ed.): The Cambridge History of Medieval Political Thought c. 350-c. 1450. Cambridge, 1988, 11-20.

De Jong, Mayke: The Penitential State: Authority and Atonement in the Age of Louis the Pious, 814-840. Cambridge, 2009.

Devisse, Jean: Hincmar: Archevêque de Reims 845-882. Genève, 1976.

Dodaro, Robert: Church and State, in: Allan Fitzgerald (ed.): Augustine Through the Ages: An Encyclopedia. Grand Rapids Michigan, 1999, 176-184.

Dvornik, François: Early Christian and Byzantine Political Philosophy: Origins and Background 2 vols. Washington, D. C., 1966.

Ganz, David: The Debate on Predestination: in: Margaret Templeton Gibson and Janet Laughland Nelson (eds.): Charles the Bald: Court and Kingdom. (2nd revised ed.). Aldershot, 1990, 283-302.

Heidecker, Karl: The Divorce of Lothar II: Christian Marriage and Political Power in the Carolingian World. Ithaca and London, 2010.

Kershaw, Paul: Peaceful Kings: Peace, Power and the Early Medieval Political Imagination. Oxford, 2011.

Marenbon, John: John Scottus and Carolingian Theology: From the De Praedestinatione, Its Background and Its Critics, to the Periphyseon, in: Margaret Templeton Gibson and Janet Laughland Nelson (eds.): Charles the Bald: Court and Kingdom. (2nd revised ed.). Aldershot, 1990, 303-325.

Markus, Robert Austin: Saeculum: History and Society in the Theology of St Augustine. Cambridge, 1970. 
Markus, Robert Austin: The Latin Fathers, in: James Henderson Burns (ed.): The Cambridge History of Medieval Political Thought c. 350-c. 1450. Cambridge, 1988, 92-122.

Martin, Rex: The Two Cities in Augustine's Political Philosophy. Journal of the History of Ideas 33, 1972, 195-216.

Meens, Rob: Sanctuary Penance, and Dispute Settlement under Charlemagne: The Conflict between Alcuin and Theodulf of Orléans over a Sinful Cleric. Speculum, 82(2), 2007, 277-300.

Nees, Lawrence: Carolingian Art and Politics, in: Richard Eugene Sullivan (ed.): The Gentle Voices of Teachers: Aspects of Learning in the Carolingian Age. Columbus, 1995, 186-226.

Nelson, Janet Laughland: Politics and Ritual in Early Medieval Europe. London, 1986.

Nelson, Janet Laughland: Kingship and Empire in the Carolingian World, in: Rosamond McKitterick (ed.): Carolingian Culture: Emulation and Innovation. Cambridge, 1994, $52-87$.

Nelson, Janet Laughland: Translating Images of Authority: The Christian Roman Emperors in the Carolingian World, in: Janet Laughland Nelson (ed.): The Frankish World, 750900. London and Rio Grande 1996, 89-98.

Nelson, Janet Laughland: Le partage du Verdun, in: Michèle Gaillard et al. (eds.): De la mer du Nord à la Méditerranée: Francia Media, une région au cour de l'Europe (c. 840-c. 1050): Actes du colloque international, Metz, Luxembourg, Trèves, 8-11 février 2006. Luxembourg, 2011, 241-254.

Patzold, Steffen: Episcopus: Wissen über Bischöfe im Frankenreich des späten 8. bis frühen 10. Jahrhunderts. Ostfildern, 2008.

Schmitz, Gerhard: Verfilzungen. Isidor und Benedict, in: Karl Ubl and Daniel Ziemann (eds.): Fälschung als Mittel der Politik? Pseudoisidor im Licht der neuen Forschung: Gedenkschrift für Klaus Zechiel-Eckes. Wiesbaden 2015, 127-152.

Schofield, Malcolm: Epilogue in: Christopher Rowe and Malcolm Schofield (eds.): The Cambridge History of Greek and Roman Political Thought. (5th printing). Cambridge, 2010, 661-671.

Schrörs, Heinrich: Hinkmar, Erzbischof von Reims: Sein Leben und seine Schriften. Freiburg i. Br., 1884.

Stone, Rachel: Morality and Masculinity in the Carolingian Empire. Cambridge, 2012.

Tavard, George Henry: Episcopacy and Apostolic Succession According to Hincmar of Reims. Theological Studies 34(4), 1973, 594-623.

Wallace-Hadrill, John Michael: Early Germanic Kingship in England and on the Continent: The Ford Lectures Delivered in the University of Oxford in Hilary Term 1970. Oxford, 1971.

Wallace-Hadrill, John Michael: The Via Regia of the Carolingian Age, in: Idem (ed.): Early Medieval History. Oxford, 1975, 181-200 (first published Oxford, 1965, 22-41).

West, Charles: Evaluating Conflict at Court: A West Frankish Perspective, in: Matthias Becher and Alheydis Plassmann (eds.): Streit am Hof im frühen Mittelalter Super alta perennis: Studien zur Wirkung der Klassischen Antike XI, 2011, 317-330.

Wilks, Michael John: Roman Empire and Christian State in the De Civitate Dei. Augustinus 12, 1967, 489-510.

Young, Frances: Christianity, in: Christopher Rowe and Malcolm Schofield (eds.): The Cambridge History of Greek and Roman Political Thought. (5th printing). Cambridge, 2010, 635-660. 


\section{Hincmar of Rheims}

\section{Dictionaries and lexica}

A Greek-English Lexicon: With a Revised Supplement, 1996. Compiled by Henry George Liddell and Robert Scott, revised and augmented throughout by Sir Henry Stuart Jones with the assistance of Roderick McKenzie. (Repr. of the new, 9th ed. 1940). Oxford, 1996.

Lewis, Charlton T. and Short, Charles: A Latin Dictionary: Founded on Andrews' Edition of Freund's Latin Dictionary. Revised, enlarged, and in great part rewritten. (1st ed. 1879). Oxford, 1969.

Mayer, Cornelius Petrus et al. (eds.) Augustinus-Lexikon vols. 1-4, Doppelfasz. 5/6. Basel, 1986-2017.

Oxford Latin Dictionary: A - Z 2 vols. Oxford, 1968-1976. 


\section{Conclusion}

This book examined the political advice of the pre-eminent Carolingian authors Alcuin of York and Hincmar of Rheims. It explored how these thinkers used Augustinian ${ }^{1}$ political thought and ethics as manifested in the De civitate Dei in order to give more weight to their instructions to the rulers. A philologicalhistorical approach allowed the identification of coherences at multiple levels of the texts.

Even though Alcuin and Hincmar were equally prolific authors and had a broad knowledge of Augustinian thought, each came away with a substantially different understanding of Augustine. This conclusion aims to shed some light on how Carolingian political thought developed and enquires into the causes of Alcuin's and Hincmar's different interpretations of Augustine.

Besides living at different times of the Carolingian period - Alcuin was an adviser to Charlemagne, ruler of the first generation, Hincmar to Charles the Bald, ruler of the third generation - the two authors also had different statuses and functions as writers and advisers. Alcuin, born in the Northumbrian kingdom, joined Charlemagne's court as a foreigner around $782 .{ }^{2} \mathrm{He}$ was only gradually accepted into the king's inner circle since his authority had first to be established. ${ }^{3}$ Apart from his extensive literary activity, he was teaching at the Frankish court ${ }^{4}$ and in his capacity as adviser guided Charlemagne in decisions regarding the 'state' and the 'church'. ${ }^{5}$ I have argued that Alcuin's opinion gained authority from 794 onward (after Charlemagne's move to Aachen) in the discourse leading up to the imperial coronation. In 796, Alcuin reluctantly left the Aachen palace when Charlemagne installed him as abbot of the monastery of Saint-Martin, although he was merely a deacon and had never in fact been ordained priest. ${ }^{6}$ He kept up a correspondence and continued to provide advice until his death. Hincmar, a native born into a noble family of Northern Francia, was appointed archbishop of Rheims in 845 and from 840 onwards was an adviser to Charles the Bald. Since he was the head of the most influential archdiocese of Western Francia, he was inclined to voice reservations about a secular power that he saw as too sovereign 7 and was critical of the imperial title conferred on Charles the Bald in $875 .{ }^{8}$ As far as his literary activity was concerned, his work was limited to specific events that had relevance to him and his archdiocese: for example, he wrote extensively in response to legal disputes. 
In my survey of the main influences on the De civitate Dei and Augustine's understanding and definitions of politically organised communities, it could be seen that the Augustinian conception of God and the ruler underwent an intellectual development from a Greco-Roman to a Judaeo-Christian view via neo-Platonism and St. Paul. A pattern in the development of 'state' formation, 'state-church' relations and political thought in the Latin West and Carolingian empire emerged; the history of ideas between 400 and 800 revealed an intellectual tradition that extended from Cicero and Virgil to Ambrose of Milan and Augustine, and was transmitted, inter alia, via Isidore of Seville ${ }^{9}$ to reach Bede and the Carolingians via Alcuin. ${ }^{10}$ Having evaluated Augustine's influence in the works of both an earlier and a later Carolingian author, it is fair to say that it was a trend to use Augustine in eighth- and ninth-century Carolingian literature - particularly in the event of political crises.

\section{Carolingian political thought c. 800-c. 900}

There are other Carolingian authors I could have included in my discussion. In the early ninth century, Smaragdus of Saint-Mihiel wrote the Via regia,${ }^{11}$ the first Carolingian 'mirror for princes'. ${ }^{12}$ The text was composed for Louis the Pious in $811 \times 814 .{ }^{13}$ It is structured into a discussion of virtues and foregrounds sapientia ("wisdom"). This is in line with Alcuin and arguably played a role in the earlier advice discourse, which consolidated and legitimised the rule of the Carolingian dynasty. Even in terms of vocabulary and mode of expression, the work resembles Alcuin's epistles. David and Solomon are strongly represented in the Via regia; while Solomon appears most in references to the virtue of sapientia, David appears often in exhortations foregrounding iustitia ("justice"), humilitas ("humility") and pax ("peace"). Similarly, sapientia appears in the vicinity of the noun gentes ("races," "tribes," "nations") in the sense of "unbelievers" who, by contrast to the Jews and Muslims, will easily open up to conversion and therefore must be "subjected" (Alcuin ${ }^{14}$ and Smaragdus ${ }^{15}$ both use the verb subicere). Thus, in the same manner as Alcuin and the Church Fathers (notably Augustine, Book V of the De civitate Dei ${ }^{16}$ ), gentes appears in the specific sense of "less influential groups of people who are to open up to conversion." This earlier political discourse, which was strongly influenced by the patristic language, reflects the earlier Carolingian political agenda that highlighted mission and expansion.

Later in the ninth century, Jonas of Orléans laid the foundation for a clearer definition of Carolingian 'state-church' relations. His political advice is characterised by a reformulation of the position of the episcopate, which was then endorsed and consolidated by Hincmar. Jonas' works are the De institutione laicali, ${ }^{17}$ a 'lay mirror' ${ }^{18}$ written for Matfrid of Orléans in 818 x 828, and the De institutione regia,${ }^{19}$ a 'mirror for princes' composed for Pepin I of Aquitaine in 831. Gelasius features prominently at the very beginning of the first chapter of the De institutione regia..$^{20}$ Departing from Gelasius, Jonas defines the bishops' responsibility for the kings' fulfilment of religious and secular duties. ${ }^{21}$ In agreement with Gregory the Great, Isidore and Smaragdus, he retains from Augustine mainly the statements 
that devalue the earthly 'state'. ${ }^{22}$ While Solomon and David are still present in passages concerning the virtues (esp. iustitia and humilitas), a variety of sources are referenced in an effort to define the episcopal duties in relation to the king. Fulgentius, Gregory the Great and, in particular, Isidore of Seville occur often. The hexameter parcere subiectis et debellare superbos from Virgil's Aeneid ${ }^{23}$ is quoted via Bede. ${ }^{24}$ The mirror work ends with a quotation from Chapter 24 of Book V of the De civitate Dei, where Augustine defines the felicitas ("happiness") of the Christian emperors. ${ }^{25}$ However, there is no trace of Jonas using the noun gentes or the verb subicere independently in a patristic sense.

Agobard of Lyon (Spanish-born author, priest and archbishop) provided direct and indirect advice to Louis the Pious and defended the 'church' property and freedom of the priests. ${ }^{26} \mathrm{He}$ commented on legal questions, and regretting the fragmentation of the empire, his efforts for unification were inspired by Augustine's concept of the civitas Dei. ${ }^{27}$

The De rectoribus Christiani ${ }^{28}$ of Sedulius Scottus is a very different 'mirror for princes' influenced by the insular tradition. Sedulius' notion of 'state-church' relations did not rely on Gelasius or Fulgentius. While Sedulius adhered to an older idea of the 'state' and 'church' unified under a king, he used res publica in opposition to ecclesia..$^{29}$ However, a clear definition of 'state-church' relations is missing in his work. Chapters VII and VIII of the De rectoribus Christianis are devoted to impii reges ("impious kings") representing bad governance; Chapter XIII advises against superbia ("pride"), which gives rise to iniustitia ("injustice"); Chapter XVII is dedicated to peaceful kings: prime examples are Alexander the Great, Constantine I and Theodosius I.

Lupus Servatus (abbot of Ferrières) integrated Christian and classical elements into his Epistolae, ${ }^{30}$ of which ca. 130 letters survive from the years 836-862. Despite his predominantly religious concerns, the admonitory letters to Charles the Bald (Epist. 33, 64 and 93) deserve to be counted among the mirror works. The high standard of his literary style is reflected in these letters, which are influenced by Cicero and contain personal political advice. Ciceronian elements in the Epistolae form part of a code of communication between him and other authorities. $^{31}$

\section{Alcuin's and Hincmar's uses of Augustine in the light of changing 'state-church' relations}

As far as my first approach to the Carolingian sources was concerned, which considered different kinds of direct references to Augustine, the findings on Augustine's influence in Alcuin and Hincmar were similar; Alcuin used Augustine explicitly as the most distinguished authority and as a binding guideline in questions relating to Christian doctrine. Hincmar made direct reference to Augustine as the prime authority in the struggle against heresy (in his epistles concerning Gottschalk's doctrine of predestination), and as a moral authority (in the Quaterniones of the Expositiones ad Carolum Regem and in the De regis persona et regio ministerio). 
Regarding the second approach to the sources, which explored the implicit evidence of Augustinian influence at the level of content and the formal level of the Carolingian texts, the findings on Augustinian influence in Alcuin and Hincmar were different; Hincmar used Augustine's De civitate Dei in a decidedly more critical way than Alcuin.

In the study of Alcuin's Epistolae, the use of the terms imperium ("supreme power") (or alternatively potestas or potentia) and sapientia with reference to Charlemagne has emerged as a recurring theme. This is not surprising, seeing that sapientia together with its antithesis fortitudo ("strength") had been an established topos among moral ideals since Virgil. ${ }^{32}$ However, it has been shown that Alcuin borrows the term imperium together with other terms from Augustine. In the De civitate Dei, imperium primarily appears in the books concerned with politics and the characteristics of Roman power. In many instances, imperium occurs in the sense of "empire" or "world power" and frequently refers to the Roman empire (imperium Romanum). Often imperium also means "supreme power (of Roman emperors)" and "command." Consequently, for Augustine, imperium as a term for a 'state' is reserved for a power that has supremacy over other 'states' and is significant within God's providential plan because it is meaningful for the development of Christianity. The title of imperator appears analogously and in similar contexts. Only once does imperium occur as a purely spiritual concept. ${ }^{33}$ Hence, for Augustine, the civitas Dei is incompatible with any form of military power.

Alcuin adopts the strong military connotation of imperium in the De civitate Dei by attributing to it an immediate political function. However, to Alcuin, the notions of imperium and imperator, which gain prominence in the correspondence leading up to Charlemagne's imperial coronation, refer to an actual people of God on earth. Alcuin imbues imperium with an additional spiritual meaning; when using the term imperium and the title of imperator with reference to Charlemagne and his 'state', it is not enough for him to link Charlemagne's empire with the eschatologically relevant empires of the Assyrians and Romans and to equate Charlemagne with the Roman imperatores. By asserting that God presented Charlemagne with the two gifts of imperium and sapientia to a higher degree than any other secular leader given the title of imperator, and by claiming that Charlemagne's perpetuae pacis civitas ranks higher than David's Old Testament Jerusalem, Alcuin portrays Charlemagne as superior to any past or present ruling figure. Throughout Alcuin's epistles, the attribute of imperium (or alternatively potestas or potentia) has a political function, that of sapientia, a religious function. While imperium serves to express Charlemagne's capacity for expanding, defending and safeguarding the empire, sapientia reflects Charlemagne's capacity for learning, spreading and defending Catholic Christian doctrine. The consistency with which Alcuin applies these terms (imperium and imperator), as well as the other Augustinian terms under discussion in this book, allows the reader to attribute to them a new, clear-cut and well-defined meaning relating to Christian Carolingian political thought.

J. Devisse maintains that Alcuin may speak up in cases where cruel methods are used in Charlemagne's military campaigns. However, the dilatatio imperii as 
such is never questioned by him. ${ }^{34}$ Military expansion that goes hand in hand with Christianisation is perfectly legitimate and is celebrated as one of Charlemagne's greatest and noblest achievements - in fact, the achievement that sets him apart from all previous and contemporary secular authorities. Charlemagne's military success is seen as God's reward for the Christian piety of the Franks.

While Alcuin does not question the legitimacy of war and military violence in the context of Charlemagne's campaigns to expand his realm, Hincmar (e.g. in the De regis persona et regio ministerio) thoroughly re-evaluates the lawfulness of war and violence in general, and he does so by drawing on Augustine's De civitate Dei. Hincmar indicates to Charles the Bald that it is not morally just for a ruler to conquer other races merely for personal glory and profit. Peace should always be the ultimate aim of any Christian ruler. ${ }^{35}$ By the later ninth century, Vikings, Muslims and Magyars had attacked the borders and brought instability to the Frankish realm. Devisse rightly observes that under these circumstances the question of the Christian piety of the Frankish people arises for Hincmar. His view, based on St. Paul and developed by Augustine and Gregory the Great, ${ }^{36}$ that disorder in society is attributable to the people's sins, explains his fear of a decline in the Christian moral standards of the Franks. Consequently, Hincmar reflects on the lawfulness of military service and of homicide in combat and as a punitive measure by referring to Augustine. ${ }^{37}$ Devisse reasons that, because of the realm's political instability, Hincmar feels compelled to support not only military service but also stringent laws that are put into writing. ${ }^{38}$ Both imply advocating a violence that is institutionalised (be it military violence or violence in the form of physical punishment) and authorised by the ruler on God's behalf. ${ }^{39}$ In contrast to violence that is governmentally approved, Hincmar condemns any form of private violence because it is not divinely authorised. ${ }^{40}$ It is striking that Hincmar attaches the rhetorical question, "In the absence of justice, what are realms, therefore, but big bands of robbers?" 41 - with which Augustine opens Chapter 4 of Book IV of the De civitate Dei - to the end of CAP. VI of the De regis persona et regio ministerio. It appears that Hincmar deliberately wants to lay stress on the importance of morally correct worldly rulership that is authorised by the Christian God.

As far as the example of the Christian Roman empire and emperors is concerned, Hincmar, on account of his legal interests, places more emphasis on Theodosius I and Theodosius II than on Constantine I. For the Christian Roman empire Augustine lived under, Augustine himself promoted a certain relationship between the 'state' and the 'church',42 above all, he recognised the imperfect worldly 'state' as an instrument of power for missionary purposes. ${ }^{43}$ Hence, he saw a functional relationship between the 'state' and the 'church' insofar as the 'state' could be used to serve the 'church'. ${ }^{44}$ Apart from that, however, he regarded the 'state' as a worldly system of power separate from the 'church' ${ }^{45}$ In the ninth century Carolingian 'state' of Charles the Bald, Hincmar also recognises a distinction between secular and ecclesiastical authority and power. ${ }^{46}$ J. L. Nelson observes:

"In a time of political crisis, the episcopate became increasingly conscious of its own unity and responsibility - a consciousness at once the cause and the 
effect of frequent synodal activity - and the archbishop of Rheims was using all his resources of political influence and canonical expertise to bring his suffragans under firmer metropolitan control." ${ }^{47}$

Similarly, Hincmar also links the royal power with the priestly authority; ${ }^{48}$ he fashions kingly professions for West Frankish royal consecrations on the model of already existing professions for episcopal ordinations. ${ }^{49}$ He formulates an idea of kingly duty on an idea of episcopal duty. ${ }^{50}$ However, on the basis of Gelasius' notion of episcopal superiority in dignity ${ }^{51}$ over royal power, Hincmar is able to determine the bishops' role as consecrators in West Frankish royal consecrations. ${ }^{52}$ The consecration-rites developed by Hincmar insist on the king's promise "to keep the laws and statutes for the people committed by God's mercy to me to rule. ${ }{ }^{53}$ In other words, beyond offering mere spiritual guidance, they point to the 'church's' authority over the king as an individual Christian ${ }^{54}$ and establish the bishops' jurisdiction over the king's comportment in a duty for which the bishops had consecrated him. ${ }^{55}$ However, although Hincmar expresses this unequivocally in his texts - as has been seen in the Quaterniones of the Expositiones ad Carolum Regem - he makes no literal claim for legal authority on the part of the bishops to depose a West Frankish king. ${ }^{56}$ Nelson takes the view that in recent scholarship a tendency has remained to understand the limitations that Hincmar places on kingship as fundamentally moral. According to her, the evidence rather indicates that Hincmar nevertheless demands, in addition to spiritual authority, a particular jurisdiction over the inaugurated king. ${ }^{57}$ It is in fact this statement that marks the contrast between Augustine's and Hincmar's perceived 'state-church' relationship; Augustine and Hincmar both envisage the 'state' and the 'church' as two separate bodies which are in a certain relationship with one another. In both cases, this relationship is characterised by a superiority of the 'church'. However, the nature of the superiority is different in each case. According to Augustine, the 'church's' superior role is not to be understood in a worldly sense at all. ${ }^{58}$ The 'church' has an immortal soul and an eternal mission, which the 'state' lacks. ${ }^{59}$ Augustine's 'church' firstly cannot be compared to any earthly systems of rule due to its timelessness, and secondly, it lacks a clear hierarchical structure. ${ }^{60} \mathrm{~K}$. Flasch and M. De Jong note that Augustine's 'church' has features similar to a community. ${ }^{61}$ Hincmar, however, when framing the royal professions in terms analogous to the episcopal professions, shows that he considers the 'church' as part of the same category as the 'state'. At the same time, he asserts the bishops' role as consecrators in royal consecrations, which implies that the royal promise is guaranteed to the 'church'. He ranks the 'church' above the 'state' within the same category. This shows that Hincmar assumes a superiority of the 'church' over the 'state' that is meant very much in a worldly sense. While there are certainly correspondences between Augustine's and Hincmar's understandings of 'state-church' relations, Hincmar never uses Augustine's notion of the civitas Dei in the way Alcuin does when establishing a formal Carolingian ruler legitimation. Hincmar omits the idea of the civitas Dei on the basis of pragmatism. His aims are practical and revolve around solving political and legal problems. Nelson writes: 
"In the painful struggle towards a positive response to contemporary political change, Hincmar was forced to modify Western ideological tradition as evolved before, and especially during, the reign of Charlemagne, in order to cope with the new realities of the reign of Charles the Bald. For Hincmar's interests as a politician were basically practical [...]." ${ }^{2}$ She adds: "His own lifetime (805/6-882) spanned the Carolingian Empire from its heyday to its dissolution: his political thought forms a bridge between the ideologies of theocratic and feudal kingship." ${ }^{3}$ Hincmar recognises that the "church' lost a lot of property through war waged by secular authorities. He also realises that the 'church' is stronger as a moral institution separate from the secular power. A condition of this is that the royal office is subject to criticism by the 'church'.

Alcuin's central goal as an adviser to the first Carolingian emperor, on the other hand, is to shape a formal legitimation of Carolingian rulership, and he does so by using the notion of the civitas Dei as an analogy to Charlemagne's 'state'. Alcuin depicts Charlemagne's 'state' as the realised Augustinian civitas Dei. Under the power of Charlemagne, the spiritual and the secular are closely joined together. It emerged that in Alcuin's epistles Charlemagne is continuously represented as the unchallenged religious leader of his people. Nelson remarks that Charlemagne himself crowned his son, Louis the Pious, in 813, and Louis in turn crowned his own son, Charles, in $838 .{ }^{64}$ By 866 , when Charles assisted in the coronation of his first wife Ermentrude at Soissons, Nelson notes that the Frankish bishops had involved themselves in both coronations and anointings. Nelson points out that, from the mid-ninth century, "coronation became, alongside anointing, permanently part of the ecclesiastical procedures of king-making." 65 In contrast to Hincmar, Alcuin does not draw on the De civitate Dei in order to tell the ruler that, as a Christian leader, he must act according to the moral code of the Frankish 'church', and that, should he fail to do so, he must humbly repent of his sins, just as his exemplary antecessores Constantine I, Theodosius I and the Old Testament kings, who were praised for their humilitas. Rather, Alcuin uses Augustine to tell Charlemagne that he is the first Christian ruler who can fulfil Augustine's condition - namely to lead a people fully under the will of God by implementing God's vera iustitia ${ }^{66}$ - for a civitas Dei.

In the Augustinus-Lexikon s.v. iustitia, Dodaro observes that Augustine's argument in the De civitate Dei is that the Romans (who lacked vera pietas) never reached the status of a res publica in Cicero's terms. ${ }^{67}$ Dodaro remarks that, in Augustine's view, the civitas Dei alone meets Cicero's definition of a res publica. Moreover, he says that based on a number of statements made by Augustine, scholarship tends to agree that even though Augustine separates vera pietas from the virtues of the pagans, he regards the latter as sufficient for maintaining a limited pax ("peace") and order in society. However, Dodaro highlights that scholarship does not agree on the extent to which Augustine regards either the imperium Romanum ("Roman empire") as a whole, whether Christian or heathen, or its individual politicians, as exhibiting anything more than a short-lived or even an Ersatz-virtue. Furthermore, he claims that in some letters to public officials and authorities engaged in secular pursuits (e.g. Augustine's epist. 48 
ad Vincentium, quoted in Hincmar's De regis persona et regio ministerio), Augustine outlines an argument concerning the transformation of the four virtutes civiles (sapientia/prudentia, temperantia, fortitudo/magnitudo animi and iustitia) beyond the fundamental level of virtue attained by pagan politicians who lack vera pietas (which consists of the knowledge and love of the true God). By allowing their conception of iustitia to be transformed by fides, spes and caritas, Christian politicians will, according to Augustine, fight wars in a more virtuous manner than that which is sustained by the Roman concept of bellum iustum, and they will punish offenders with iustitia tempered with misericordia ("forbearance"). ${ }^{68}$

I have investigated how Hincmar utilises this correspondence together with the quotations from the De civitate Dei that relate either to the Christian Roman empire or to Cicero's model of a just social order. The question has been posed about the function performed by Hincmar's resorting to Augustine's discussion of Christian leadership. Looking at the virtue of iustitia from Hincmar's point of view, a clear distinction has been revealed between iustitia and vera iustitia (achieved only by those who practise vera pietas, which consists of the knowledge and love of the true God). That a ruler practices vera pietas is the precondition for the people to obey him as well as the laws enforced by him. The Christian form of iustitia (i.e. vera iustitia) is used by Hincmar as a means to compel the people to its observance and practice. Secondly, Hincmar differentiates between the vera iustitia of Christian rulers and the iustitia of pagan rulers, in order to dissociate the Germanic heathen idea of rulership from the Christian idea of rulership (e.g. the one held by the Christian Roman emperors). Hincmar aims to show that the Christian moral code of secular leadership (and Christian political ethics in general) is superior to the heathen one. It is therefore justified to say that, according to Hincmar's understanding, the Christian iustitia (i.e. vera iustitia) is exalted. Hincmar does not, however, enquire whether this Christian form of iustitia enforced in Charles the Bald's realm fulfils the criteria for that realm to be equivalent to a civitas Dei. This is chiefly because Hincmar looks at the Christian form of iustitia (i.e. vera iustitia) only from the ruler's point of view, without reflecting on its realisation within a social order as a whole. Unlike in Alcuin's epistles, in which vera iustitia or divina iustitia as well as pax appear as timeless, transcendent concepts, Hincmar's pondering does not reach beyond the point where vera iustitia, from the ruler's perspective, can compel the people to the observance of the law - on which basis pax is enforced - and where it can claim distinctness from the pagan (Germanic) iustitia. That is to say, Hincmar fundamentally institutionalises vera iustitia or divina iustitia and pax. According to Hincmar, vera iustitia or divina iustitia can solely be implemented by being put into writing. The law imposed and recorded by Charles the Bald's predecessors, the Christian Roman emperors, as well as by the 'church' councils, is part of the vera iustitia or divina iustitia. Hincmar instrumentalises the concept of vera iustitia or divina iustitia in order to alert Charles the Bald - together with the Frankish people - to the importance of observing the law that derives directly from God 
and is enforced by the ruler on God's behalf. Hincmar argues along these lines with the aims of establishing peace and order and promoting the Christian faith in Carolingian society; his goal was that everyone should understand the urgency of participating in this affair.

The main concern of this book has been to investigate how the political thought of Augustine of Hippo was understood and modified by two pre-eminent Carolingian-era writers to serve their own distinctive purposes. Internationally, more interdisciplinary, comparative and inclusive research is needed on the Latin West - both in terms of source analysis and methodology. My study has contributed to interdisciplinary research in the history of political thought, early medieval European 'state' formation, and the developments between religious and secular power in Western Europe from the ancient to the medieval world. Further work is certainly required to disentangle these complexities. However, the philologicalhistorical approach I propose aims to encourage debate on methodologies in the study of Latin political advice and to enable research to reach beyond national and disciplinary traditions. Further enquiries into the language of governance in Latin sources may contribute towards an understanding of foreign terms used within European research on ideas of rulership. The proposed method may even be applied to intercultural/interlingual studies in the history of political thought and relations between religious and secular power, for example, between the Latin West, the Greek East and the Muslim world.

\section{Notes}

1 By 'Augustinian', I refer to the thought that is manifested in Augustine's later work - in particular the De civitate Dei.

2 Bullough 2004, pp. 164-165, 331-337.

3 Ibid., pp. 390, 401.

4 For details regarding Alcuin's restructuring of the teaching system at the Frankish court, see Brunhölzl 1967, pp. 32-41.

5 Bullough 2004, p. 372.

6 Ibid., pp. 306, 435.

7 On resistance to kings and emperors in the Carolingian age, see Wallace-Hadrill 1971, pp. 127-128 and Wallace-Hadrill 1975, pp. 184-185, 192-197.

8 See Anton 1968, p. 282.

9 Leyser 2012, p. 453.

10 Nelson 1988, p. 230.

11 Via reg.

12 Anton 1968, pp. 132-179; Bovendeert 2006, pp. 239-252; Eberhardt 1977, pp. 197263; Hadot 1900/1999, p. 622; Kershaw 2011, pp. 177-180; Rädle 1974, pp. 62-71; Scharf 1961, pp. 333-371; Schmidt 1961, pp. 16f.; Stone 2012, p. 42.

13 I adhere to Stone 2012, p. 29 and Anton 1968, pp. 161-168 on the date and addressee of the Via regia.

14 Epist. 178, pp. 294-296; Epist. 257, pp. 414-416.

15 Exteras etiam gentes fortiter facit debellare minaces, et nationes subjici diras, et reges calcari feroces, et ut ita dicam, in sapientia constat regni dispositio cuncta. Via reg. PL 102, col. 0943C. ... et cordi tuo intellectum sapientiae multiplicet; quae tibi multarum gentium colla subjiciat .... Ibid., col. 0946A. 


\section{Conclusion}

16 Civ. V.

17 De inst. laic.; Savigni 2002, pp. 71-80; Sedlmeier 2000, pp. 191-372; Sot 2009, pp. $341 \mathrm{ff}$; S Stone 2012, p. 36.

18 Stone 2012, pp. 36-42. Blum underlines the uniqueness of this kind of advice for the layman in the Latin West. Blum 1981, pp. 12, 49f.

19 De inst. regia. See also Reviron 1930.

20 Vnde Gelasius Romanae imperatorem scribens: "Duae sunt, inquit, imperatrices augustae, quibus principaliter hic regitur mundus: auctoritas sacra pontificum et regalis potestas. In quibus tanto est grauis pondus sacerdotum, quanto etiam pro ipsis regibus hominum in diuino sunt examine rationem reddituri." De inst. regia, 176, 11. 9-16.

21 Anton 1968, pp. 198-245; Blum 1981, pp. 11f.; Hadot 1900 / 1999, p. 622; Scharf 1961, pp. 371-384; Schmidt 1961, pp. 23-40.

22 Arquillière 1934, pp. 148-152.

23 Aen. 6.853.

24 De inst. regia, 208, 11. 59-60.

25 Ibid., 282-284, 11. 9-42.

26 Acker van 1981.

27 Schmidt 1961, pp. 72-77; Boshof 1969; De Jong 2009a, pp. 51-53, 142ff.; Kershaw 2011, pp. 189-196; Stone 2012, pp. 43f.

28 De rect. Christ. According to Stone and Staubach, the text was designed for Charles the Bald in 869 x 870. Stone 2012, 42, 92-93; Staubach 1993, 105-197. Older scholarship assumes that the work was written for King Lothar II in 855 x 859. Anton 1968, 261281; Blum 1981, 12; Hadot 1900/1999, 622-623; Kershaw 2011, 223-234; Schmidt 1961, 61-68.

29 Anton 1968, 279-280; Schmidt 1961, 68.

30 Levillain 1927-1935; for a translation, see Regenos 1966.

31 For further reading, see Anton 1968, pp. 248-254; Davy 2005, pp. 49-71; Kershaw 2011, pp. 216-218; Margalhan-Ferrat 1999, pp. 7-21; Noble 1998, pp. 232-250; Orlandi 2004, pp. 99-122; Patzold 2008, pp. 249f., 260-264, 269f.; Ricciardi 2005; Schmidt 1961, pp. 69-72; Steckel 2011, pp. 377-485; Stone 2012, pp. 29, 64, 85, 86, 135, 244.

32 Curtius 1961, pp. 171-190. As far as the classical topoi of "wisdom" and "strength" are concerned, we of course find them represented in the ancient Greek epic poetry attributed to Homer. According to Homer, the optimal performance in war is achieved by a balance between "mind" and "strength." Only in Odysseus, however, do "wisdom" and "strength" seem to be united in equal measure. Cicero, who reformulated the argument of Polybius by saying that according to Roman history the key element in the Romans' rise was first from the wisdom and moral superiority of individuals, contributed to the integration of these ideals into Roman political thinking. After Virgil's Latin epic poem, the Aeneid, which is linked in many ways to Homer, sapientia and its antithesis fortitudo became an established topos among moral ideals in classical Latin literature. In the Early Middle Ages, Germanic epic poetry originating from the Ostrogoths existed in the form of heroic songs, which were, however, oral rather than literary. In late antique and early medieval Latin epic poetry, the novels about Troy by Dictys Cretensis (Ephemeris belli Troiani, fourth century) and Dares Phrygius (De excidio Troiae historia, fifth/sixth century) were important in shaping the medieval topoi of sapientia and fortitudo. Fulgentius was prominent in late antique Latin literary theory. According to his allegory, the topoi of sapientia and fortitudo were contained in the very opening words of Virgil's Aeneid, namely in arma virumque cano ("I sing of arms and the man"): while arma was supposed to represent fortitudo, virum was supposed to represent sapientia. Isidore of Seville, an intermediary between the ancient and the Carolingian worlds, writes in his reflections on epic: "It is called heroic song, because it recounts the deeds of brave men. For heroes are men who are worthy of heaven on 
account of their wisdom and strength." Cited in ibid., p. 184. The topoi of sapientia and fortitudo are henceforth used in medieval threnody, panegyric and epic. Ibid., pp. 176-184.

33 Civ. II 29, p. 96, 11. 7-8.

34 Devisse 1976, p. 529. This is also well formulated in Wallace-Hadrill 1971, p. 105.

35 See Devisse 1976, p. 530.

36 See CAP. I. of the De regis persona et regio ministerio.

37 See Devisse 1976, p. 531.

38 Devisse finds that written laws have a fundamental social value according to Hincmar, since they are immediately and easily coercive for the person who transgresses them and allow for the rapid restoration of justice in a disrupted society. Ibid., p. 560.

39 Ibid., pp. 531-534.

40 Ibid., p. 533.

41 Remota itaque iustitia quid sunt regna nisi magna latrocinia? Civ. IV 4, p. 150, 11. 19-20.

42 Flasch 2003, pp. 391, 393.

43 See Campenhausen von 1964, pp. 238-240. Regarding imperial repression, see Dodaro 1999, pp.180-181. On Augustine and religious coercion under Theodosius I and his successors, see Markus 1988, pp. 113-115.

44 Flasch 2003, pp. 164, 391-393. This is confirmed by R. Dodaro, who writes that with the reign of Emperor Constantine I “... and continuing into the early Middle Ages, the governing structures of the Christian church and of the Roman Empire developed closer relationships, even while retaining their separate identities.” Dodaro 1999, p. 176. See also Markus 1988, p. 86; Baynes 1936, pp. 14-15.

45 Flasch 2003, pp. 391-392; Dempf 1973, p. 134; Baynes 1936, p. 15.

46 This is supported by Anton 1968, pp. $311 \mathrm{ff}$.

47 Nelson 1986, p. 144.

48 Hincmar probably played the leading role in the appropriation of the royal rite by West Frankish bishops. Ibid., pp. 137, 149.

49 Ibid., pp. 138, 145-146, 155; Nelson 1994, p. 66.

50 Four of the ordines, the texts written for Carolingian royal consecrations, were compiled by Hincmar: the ordo $(V)$ for the marriage and coronation of Judith (daughter of Charles the Bald) at Verberie (Oise) on 1 October 856; the ordo (VI) for the anointing and coronation of Ermentrude (first wife of Charles the Bald) at Soissons on 25 August 866; the ordo (VII) for the coronation of Charles the Bald as king of Lorraine in the cathedral of St. Stephen in Metz on 9 September 869; the ordo (VIII) for the coronation of Louis the Stammerer as king of the West Franks at Compiègne on 8 December 877. See Ord., pp. 73, 80, 87, 110; Nelson 1986, pp. 137-138. A more in-depth treatment of how the ordines may reflect the nature of royal power in the ninth century can be found in Wallace-Hadrill 1971, pp. 133-135; Nelson 1986, pp. 142-171; Nelson 1996b, pp. $102 \mathrm{ff}$.

51 Nelson argues that the consecrators' maior dignitas implies superior governmental position in addition to superior sacramental powers. Nelson 1986, pp. 140, 142.

52 According to Gelasius, the authority of the 'church' is superior to secular authority. In his understanding, the 'church' will eventually be held accountable for the actions of the secular leaders, whose power has been given by the 'church'. See also Anton 1968, pp. 307, 311ff.

53 Nelson 1994, p. 66; see also Nelson 1986, p. 153.

54 On the development of the principle that rulers as individual Christians are subject to ecclesiastical censure, see Anton 1968, pp. 285ff.; Wallace-Hadrill 1975, pp. 192-195; Nelson 1986, pp. 134-135; Markus 1988, pp. 95-102.

55 Nelson 1986, p. 169; Nelson 1994, p. 66. 
56 This becomes evident, inter alia, in CAP. I. of the De regis persona et regio ministerio. The point also emerges from the discussions in Wallace-Hadrill 1971, pp. 99, 125, 127-128, 133-135; Wallace-Hadrill 1975, pp. 192-197. Nelson, however, in contrast to previous scholars (e.g. M. David, K. F. Morrison, J. M. Wallace-Hadrill, H. H. Anton), takes her argument one step further. She seems to attribute to Hincmar not only an elaborate reassessment of the royal office, but also a refined procedure for confronting “... the problem of controlling its exercise." Nelson 1986, p. 135. She argues convincingly that Hincmar claimed both sacramental powers and a specific episcopal jurisdiction over the consecrated king. Ibid., pp. 155-164, 169. However, it appears that Hincmar left the mechanics of earthly deposition unspecified. Ibid., pp. 164-171. Thus, it must be Hincmar's refined treatment of law and liturgy that tempted Nelson to consider Hincmar as a "theorist" and attribute to him a "... theory of restraints on Christian kingship ....” Ibid., p. 134; Nelson 1992, p. 49.

57 Nelson 1986, p. 169.

58 Flasch 2003, p. 391; Baynes 1936, pp. 14-15.

59 Flasch 2003, p. 392. R. A. Markus uses the phrase “... an 'otherworldly' Church ..." to render this meaning. Markus 1970, p. 133.

60 Flasch 2003, pp. 386-388.

61 Ibid., p. 388; De Jong 2009b, p. 242.

62 Nelson 1986, p. 169.

63 Ibid., p. 171.

64 Nelson 1996b, p. 103.

65 Ibid.

66 Civ. II 21, p. 83, 11. 9-14.

67 AL vol. 3 2004-2010, p. 879.

68 Ibid.

\section{Bibliography}

\section{Primary sources}

Acker van, Lieven (ed.): Agobardi Lugdunensis opera omnia. (CCCM 52). Turnhout, 1981.

Alcuinus: Epistolae. Ernst Dümmler (ed.) (MGH Epp. 4). Berlin, 1895.

Augustinus Hipponensis: Sancti Aurelii Augustini episcopi De civitate Dei libri XXll 2 vols. Bernhard Dombart et Alfons Kalb (recogn.). (5th ed.). Stuttgart, 1993.

Aurelianensis, Ionas: De institutione laicali. (PL) vol. 106, cols. 121-278.

Aurelianensis, Ionas: De institutione regia = Le métier de roi. Introduction, texte critique, traduction, notes et index par Alain Dubreucq (Sources chrétiennes 407). Paris, 1995.

Levillain, Léon (ed. and trans.): Loup de Ferrières: Correspondance, 829-862 2 vols. (Les Classiques de l'histoire de France au moyen âge 10, 16). Paris, 1927-1935.

Ordines Coronationis Franciae: Texts and Ordines for the Coronation of Frankish and French Kings and Queens in the Middle Ages. Richard Jackson (ed.). Philadelphia, 1995.

Regenos, Graydon W.: The Letters of Lupus of Ferrières. The Hague, 1966.

Reviron, Jean: Les idées politico-réligieuses d'un évêque du IXe siècle: Jonas d'Orléans et son De institutione regia. Paris, 1930.

Scottus, Sedulius: De rectoribus Christianis. Ed. and transl. by Robert Dyson. Woodbridge, 2010.

Smaragdus: Via regia. (PL) vol. 102, cols. 933-71.

Vergilius Maro, Publius: Aeneis. Gian Biagio Conte (recensuit atque apparatu critico instruxit). Berlin, 2009. 


\section{Secondary sources}

Anton, Hans Hubert: Fürstenspiegel und Herrscherethos in der Karolingerzeit. Bonn, 1968.

Arquillière, H.-X.: L'Augustinisme politique: Essai sur la formation des théories politiques du Moyen-Âge. Paris, 1934.

Baynes, Norman Hepburn: The Political Ideas of St. Augustine's De Civitate Dei. Historical Association Pamphlet 104, 1936, 3-18.

Blum, Wilhelm: Byzantinische Fürstenspiegel: Agapetos, Theophylakt von Ochrid, Thomas Magister. Stuttgart, 1981.

Boshof, Egon: Erzbischof Agobard von Lyon: Leben und Werk. Kölner historische Abhandlungen 17, 1969.

Bovendeert, Jasmijn: Royal or Monastic Identity? Smaragdus' Via regia and Diadema monachorum reconsidered, in: Richard Corradini, Rob Meens, Christina Pössel and Philip Shaw (eds.): Texts and Identities in the Early Middle Ages. Wien, 2006, 239-251.

Brunhölzl, Franz: Der Bildungsauftrag der Hofschule, in: Bernhard Bischoff (ed.): Das geistige Leben, Karl der Grosse: Lebenswerk und Nachleben vol. 2. (3rd ed.). Düsseldorf, 1967, 28-41.

Bullough, Donald A.: Alcuin: Achievement and Reputation: Being Part of the Ford Lectures Delivered in Oxford in Hilary Term 1980. Leiden, 2004.

Campenhausen von, Hans: The Fathers of the Latin Church. Transl. by Manfred Hoffmann. London, 1964.

Curtius, Ernst Robert: Europäische Literatur und lateinisches Mittelalter. (3rd ed.). Bern and München, 1961.

Davy, G.: Les enjeux du conseil dans les écrits de Loup de Ferrières (805-862) "non est consilium contra dominum". Revue française d'histoire es des idées politiques 21, 2005,49-71.

De Jong, Mayke: The Penitential State: Authority and Atonement in the Age of Louis the Pious, 814-840. Cambridge, 2009a.

De Jong, Mayke: The State of the Church: Ecclesia and Early Medieval State Formation, in: Walter Pohl and Veronika Wieser (eds.): Der Frühmittelalterliche Staat-Europäische Perspektiven. Budapest, 2009b, 241-254.

Dempf, Alois: Sacrum imperium: Geschichts- und Staatsphilosophie des Mittelalters und der politischen Renaissance. (4th ed.; 1st ed. 1929). Darmstadt, 1973.

Devisse, Jean: Hincmar: Archevêque de Reims 845-882. Genève, 1976.

Dodaro, Robert: Church and State, in: Allan Fitzgerald (ed.): Augustine Through the Ages: An Encyclopedia. Grand Rapids, Michigan, 1999, 176-184.

Eberhardt, Otto: Via Regia: Der Fürstenspiegel Smaragds von St. Mihiel und seine literarische Gattung. Münstersche Mittelalter-Schriften 28,1977.

Flasch, Kurt: Augustin: Einführung in sein Denken. (3rd, supplemented ed.). Stuttgart, 2003.

Hadot, Pierre: Fürstenspiegel. Rome, 1900/1999.

Kershaw, Paul: Peaceful Kings: Peace, Power and the Early Medieval Political Imagination. Oxford, 2011.

Leyser, Conrad: Augustine in the Latin West, 430-ca 900, in: Mark Vessey (ed.): $A$ Companion to Augustine. Chichester 2012, 450-464.

Margalhan-Ferrat, C.: Loup de Ferrières et la papauté: une question d'eeclésiologie carolingienne. Mémoires de la Société pour l'Histoire du Droit est des Institutions des Anciens Pays Bourguignons, Comtois et Romands. 56, 1999,7-21. 
Markus, Robert Austin: Saeculum: History and Society in the Theology of St Augustine. Cambridge, 1970.

Markus, Robert Austin: The Latin Fathers, in: James Henderson Burns (ed.): The Cambridge History of Medieval Political Thought c. 350-c. 1450. Cambridge, 1988, 92-122.

Nelson, Janet Laughland: Politics and Ritual in Early Medieval Europe. London, 1986.

Nelson, Janet Laughland: Kingship and Empire, in: James Henderson Burns (ed.): The Cambridge History of Medieval Political Thought c. 350-c. 1450. Cambridge 1988, 211-251.

Nelson, Janet Laughland: Charles the Bald. London and New York, 1992.

Nelson, Janet Laughland: Kingship and Empire in the Carolingian World, in: Rosamond McKitterick (ed.): Carolingian Culture: Emulation and Innovation. Cambridge, 1994, 52-87.

Nelson, Janet Laughland: The Lord's Anointed and the People's Choice: Carolingian Royal Ritual, in: Janet Laughland Nelson (ed.): The Frankish World, 750-900. London and Rio Grande, 1996, 99-131.

Nicol, Donald MacGillivray: Byzantine Political Thought, in: James Henderson Burns (ed.): The Cambridge History of Medieval Political Thought c. 350-c. 1450. Cambridge, 1988, 51-79.

Noble, Thomas F. X.: Lupus of Ferrières in His Carolingian Context, in: Alexander Callander Murray (ed.): After Rome's Fall: Narrators and Sources of Early Medieval History. Toronto, 1998, 232-250.

Orlandi, G.: Lupo die Ferrière e la saggezza di epistolare. Filologia mediolatina, 11, 2004, 99-122.

Patzold, Steffen: Episcopus: Wissen über Bischöfe im Frankenreich des späten 8. bis frühen 10. Jahrhunderts. Ostfildern, 2008.

Rädle, Fidel: Studien zu Smaragd von Saint-Mihiel. Medium Aevum: Philologische Studien 29, 1974.

Ricciardi, A.: L'epistolario di Lupo di Ferrières: Intellettuali. relazioni culturali e politica nell' età di Carlo il Calvo, in: Instituzioni e società, 7, Spoleto 2005.

Savigni, R.: Les laics dans l'ecclésiologie carolingienne: Normes statutaires et idéal de "conversion", in: M. Lauwers: Guerriers et moines: Conversion et sainteté aristocratiques dans l'Occident médiéval (IXe-XIIe siècle). Antibes, 2002, 41-92.

Scharf, Joachim: Studien zu Smaragdus und Jonas. Deutsches Archiv für Erforschung des Mittelalters 17(1), 1961, 333-384.

Schmidt, Werner Andreas: Verfassungslehren im 9. Jahrhundert: Die Fürstenspiegel und politischen Schriften des Jonas von Orléans, Hinkmar von Reims, Sedulius Scottus, Servatus Lupus von Ferrières und Agobard von Lyon. Mainz, 1961.

Sedlmeier, F.: Die laienparänetischen Schriften der Karolingerzeit. Untersuchungen zu ausgewählten Texten des Paulinus von Aquileia, Alkuins, Jonas' von Orléans, Dhuodas und Hinkmars von Reims. Neuried, 2000, 451-518.

Sot, Michel: Concordances et disconcordances entreculture des élites laïques et culture des élites cléricales à l'époque carolingienne: Jonas d'Orléans et Dhudda, in: François Bougard, Régine Le Jan and Rosamond McKitterick (eds.): La culture du haut moyen âge. Une question d'élites? Turnhout, 2009, 341-361.

Staubach, Nikolaus.: Rex christianus: Hofkultur und Herrschaftspropaganda im Reich Karls des Kahlen. Teil 2: Die Grundlegung der "religion royale”. Köln, 1993.

Steckel, Sita: Kulturen des Lehrens im Früh- und Hochmittelalter: Autorität, Wissenskonzepte und Netzwerke von Gelehrten. Norm und Struktur, 39, 2011, 377-485. 
Stone, Rachel: Morality and Masculinity in the Carolingian Empire. Cambridge, 2012.

Wallace-Hadrill, John Michael: Early Germanic Kingship in England and on the Continent: The Ford Lectures Delivered in the University of Oxford in Hilary Term 1970. Oxford, 1971.

Wallace-Hadrill, John Michael: The Via Regia of the Carolingian Age, in: Idem (ed.): Early Medieval History. Oxford, 1975, 181-200 (first published Oxford, 1965, 22-41).

\section{Dictionaries and lexica}

Mayer, Cornelius Petrus et al. (eds.): Augustinus-Lexikon vols. 1-4, Doppelfasz. 5/6. Basel, 1986-2017. 
$\Longrightarrow$ Taylor \& Francis Taylor \& Francis Group http://taylorandfrancis.com 


\section{Index}

1 Corinthians 178

2 Maccabees 180

Abbot Angilbert of Saint-Riquier 4, 69, 106

Abbot Lupus Servatus of Ferrières 135, 138,225

Acts of the Apostles 179

Adoptionism 75, 90

Aeneas 47, 84, 111

Alaric I 22

Alcuin of York: correspondence 69, 75, 82, 86, 89; Epistolae 4, 9, 69-70, 72-76, 81-99, 101-106, 109-110, 112-114, 134-139, 141, 143-153, 168, 172-173, 176-178, 204-206, 224, 226, 229-230; political ideas 69 ; political thinking $4,69,106$; texts $6,8,70,94,97,108$, $111-112$

Anton, H. H. 2, 12n20

Apuleius 195-196

Archbishop Amolo of Lyons 135, 146

Archbishop Ebbo of Rheims 183

Archbishop Rabanus Maurus of Mainz 138, 155n54, 184

Archbishop Remigius of Lyon 138-139

Archbishop Theodore 137, 143

Archbishop Theodulf of Orléans 82, 91, 168,177

Archbishop Wenilo of Sens 140

Arendt, H. 33-34, 46, 57n2

Arianism 40, 170

Arquillière, H.-X. 1-2, 54-55, 63n104, 70, $86,161 \mathrm{n} 120,203-204$

Assyrians 108-109, 111, 113; empire 36, 203, 226; polytheistic 35,202 ; realms 84; state $36,60 \mathrm{n} 36,202$

Athenians 25, 30n69, 35, 72, 111, 202

Auerbach, E. 5-6, 8, 93-94
Augustine of Hippo: Academic Scepticism 22; belief in Providence 53; birth 22; Carolingian interpretation of 5 ; church 9, 228; conception of the city of God 2; criticism of Cicero 32, 202; death 137, 140; De civitate Dei 1, 3-4, 6-9, 11, 21-25, 32, 34-36, 38-40, 46-51, 53-57, 69-70, 81, 84-85, 88-89, 94-95, 100-102, 104-111, 113, 133-136, 144, 147-148, 153, 168, 170, 177-178, 187, 190-195, 197-198, 200-203, 205, 207-208, 210, 223-227, 229-230; denouncing Roman gods 47-48; discourse on divine and earthly rule 56; doctrine of predestination 137; doctrine of salvation 138; evaluation of Christian earthly rulership 100; on heresy 40 ; hierarchy of worldly 'states' 203; humilitas 39; ideas 5, 8; influence on Alcuin 5-6, 69, 81, 112, 205, 225-226; influence on Carolingian political thought 2; influence on Hincmar 5-6, 133, 137, 190-191, 225-226; influence on Isidore's terminology 112; interpretation of the Psalms 111; judgment on Jewish people 35; Lexikon 53, 55, 110, 133-134, 190-191, 194, 198, 203, 229; moral values 5; political discourse 93, 101, 191, 194; political ethics $6,113,134,136,189,199-201$; political ideas $6,21,54$; on politically organised communities 32,57 ; political reflections 32 ; political thought 5,37 , $46,54,56,70,113,134,200,223$; pseudo- 137-138, 153; retirement to Cassiciacum 22; on rulership 81; safeguarding peace on earth 35 ; spiritual community 48,111 ; terminological inconsistency 46; theology of the 
saeculum 2 ; thought $2,6-8,24,33,35$, $53,70,93,113,138$; worldly rulership 32,100

Avars 13n67, 74, 104

Baynes, N. H. 1, 27n25, 61n58

Beatitudes 54, 195

Bede 106, 135, 137, 143, 149, 224-225

Bishop Ambrose of Milan 22-23, 26n18, $38-39,75,168,170,174,176-177,187$, 197, 200, 224

Bishop Arn of Salzburg 4, 69, 106

Bishop Cyprian of Carthage 72-73, 75, 149, 187

Bishop Ebbo of Grenoble 141-142, 183

Bishop Elipandus of Toledo 90

Bishop Fulgentius of Ruspe 71, 73, 225, 232n 32

Bishop Hincmar of Laon 165-166, 169, $175,177,180$

Bishop Ibas 141

Bishop Joseph of Tours 82

Bishop Julian of Eclanum 150

Bishop Pardulus of Laon 138

Bishop Prudentius of Troyes 138

Bishop Remigius of Rheims 137, 143, 187

Bishop Rothad of Soissons 165, 184

Boler, J. 2, 41n1

Bullough, D. A. 2, 69-70, 106-107, 110, 112

Byzantine: emperor 99; imperial dignity 99-100; ruler 99

Caesar Augustus 112

Caesar Octavian 111

Candidus 86, 106

Carolingian: administrative structure 9; advisers 56; authors 6-7, 223-224; capitularies 168,182 ; condition 8 ; court 82,86 ; dynasty 224 ; empire $1,5,9,224$, 229 ; era 5; history 2,9 ; imperial dynasty 1, 8; law 10; legal proceedings 137; literature 224; manuscripts 109; material 3, 21; period 1-2, 137, 223; political advisers 3; political agenda 224; political ideas 6,10 ; political relations 10; political statements 7; political thought $2-5,8,24,56,136,223,226$; politics 9-10; realm 70, 89, 114, 206; rule $1,4-5,10,96,101,113,177$; rulers 3, 9-10, 89, 102, 136, 177-178, 191, $205,228-229$; society 10,231 ; sources 3, 6-7, 21, 46, 133, 225; supremacy
103; texts $1,6-8,21,226$; theologians 137; thought 2, 7; see also Augustine; church, state

Cassiodorus 71, 73, 144

Catholic 141; church 90, 92, 114, 152, 181; doctors 185; doctrine 72-73, 90, 134, 143, 226; exposition 145; faith 85, 87-88, 91, 113-114, 134, 143, 205; Fathers 140; learning 71; non- 140; peace $115 \mathrm{n} 24$; preaching 87

Catholicism 55, 90, 204

Charlemagne: and Catholicism 55, 204; imperial coronation $70,82-84,87$, $101,103,106,112,168,177,223,226$; imperial plan 1; loss of religion 172; military campaigns 3,226 ; move to Aachen 86, 92, 112, 223; political and religious responsibilities 83,85 ; power 84, 103, 105, 229; pseudonyms 86; realm 176; reign 2-3, 55, 87, 204, 229; thirst for gathering wisdom 71; see also Alcuin of York; empire

Christ 23, 35-37, 40, 48, 53, 71-72, 75, 83-84, 87, 89, 92-93, 96-97, 99, 102, $113,138,151,178-179,191,193$, 204-205, 207

Christian: argument 24; belief 38, 101, 170; code of conduct 149, 182, 193; community 23 , 90-91, 93, 114, 172; doctrine 5, 40, 70-72, 74-75, 85, 112 , 134, 172, 193, 208-209, 225-226; emperors 23, 37-38, 40, 100, 109, 151, 170, 177, 190, 192, 225; ethics 39, 195,197 ; faith $2,38,40,74,85,93$, 102, 105, 112-113, 134, 192, 203, 231; influence 5; institution 9; Judaeo- 10, 56, 224; life 4, 136; morals 23, 54, 91 , 172, 191, 203, 209, 227, 230; order 23, 51; philosophers 39; political ethics 4, 136, 230; political thought 23-24, 57, 134; prophecy 38 ; religion $9,40,48$, $101,103,105,198$; rulers $4,39-40,56$, $81,87,89,113,136,177,191,204-205$, 209, 230; society 199-200; spiritual power 9; texts 5, 186; thought 5, 23, 187; tradition 23; see also church; power Christianising 2, 23, 104

Chrysostom, John 187 church: authority 228; Carolingian 9, 138; of Christ 83, 96, 99; Christian 21, 26n13, 38, 41, 56, 87, 100, 102, 138, 170; councils 9, 143, 197, 206-207, 230 ; dignity of 178 ; earthly 40 ; 
eternal 178-179; Fathers 5-6, 70, 113, 144-145, 152, 186, 206, 224; Frankish 229 ; growth of 35 ; holy mother 92 ;

Holy Roman 143; immunity 170; involvement 149; Latin 138, 142; law 207; as mediator 56 ; property 4,165 , 167, 171-172, 174, 225; provinces 138-139; right of sanctuary 178; sacred 170; state- 224-225, 228; superiority of 228; universal 180-181; wealth 3; see also Catholic

Cicero, Marcus Tullius 23-25, 32, 34, 39, 47-50, 56, 81, 108, 189-190, 200-202, 207-210, 224-225, 229-230; Stoicism 23, 209

Classical Roman Period 48, 50-51, 101,111

conflict 2, 32-33, 49, 82, 165, 183-184, 202-203

council: African 142; of Carthage 114n9; of Cividale 90; ecumenical 206; episcopal 14n69, 184; of Frankfurt 14n72, 90; late Roman 9; of Orange 137; of Quierzy 184; of Regensburg 90; of Savonnières 184; of Soissons 183; of Toledo 152; of Valence 184; see also church

damnation 146-147, 153

Devisse, J. 135, 154n3, 155n54, 183, 185186, 192, 206-207, 226-227, 233n38

diocese 2, 145, 151, 166; arch- 165, 183, 223; of Chur 94

divine: affairs 71, 134, 151; clemency 91; commandments 89, 205; constitutions 178-179; correction 176; dimension 34; dispensation 97-98; examination 151; favour 53-54, 194; foreordaining of damnation 146; grace 84, 95, 104; happiness 195; honour 143; judgment 190; justice 55, 203; kingship 125n219; law 25, 29n62, 33, 56, 179, 202; memory 143 ; origin 50 ; piety 97 , 116 n26; power $84,102,105$; privilege 54, 195; prophecies 35; providence $35,96,110,202$; rule $25,52,56$; sense 29n62, 55, 203; spiritual goods 52; will 200; wisdom 145; world order 52

Dodaro, R. 13, 55, 190, 203, 208-209, 229, 233n 44

Dunbabin, J. 11

Dvornik, F. 2, 32, 54-55, 63n105, 203-204 ecclesiastic: agreement 166; authority 227 ; canons 178, 180, 206; court 149; culture 21; goods 166-167, 171, 174; guidance 172; instruction 38, 170; law 165, 175, 185 ; legal source material 182 ; power 2, 185, 227; privileges $165,170,180$; property 174,182 ; provinces 2,139 ; sanctions 152; support 173; texts 182; tribunal 167; tributaries 167

Egyptians 25, 35, 108, 111, 202

Emperor Arcadius 170

Emperor Constans 170

Emperor Constantine I 7, 22-23, 38-41, 44n81, 53, 56-57, 82, 100, 109, 133, $135,167,169-170,177-178,190-191$, 194, 203, 225, 227, 229

Emperor Constantine IV 99-100, 174

Emperor Constantius II 170

Emperor Gratian 38, 174

Emperor Honorius 82, 170, 174, 177

Emperor Lothar I 138-139, 141, 183

Emperor Louis II of Italy 184, 192

Emperor Theodosius I 7, 38-41, 56-57, $100,109,133,168,170,174,176-178$, 190-192, 203, 225, 227, 229

Emperor Theodosius II 82, 168, 171, 174, 227

Emperor Valens 170, 174

Emperor Valentinian I 170, 174

Emperor Valentinian II 38

empire (imperium): Assyrian 36, 203, 226; Carolingian 1, 5, 9, 224, 226, 229; Charlemagne's 2, 84-85, 87; Frankish 103; Roman 3-4, 9, 21, 23, 36-37, 47-48, 51, 100, 102, 105, 109-110, 170, 190, 192, 203, 226-227, 229-230; worldly 47; see also Christian

Ephesians 179

Epicurean 24, 187, 207

ethics $1,4,7,21,39,54,56,196,223$; political 2-8, 21, 133-134, 136, 189, 198-201, 209, 230; social 198-200; see also Christian

Eusebius of Caesarea 23, 36-37, 51

Fathers 71-72, 74-75, 135, 144, 146; Catholic 140; Church 6, 70, 144-145, 152, 186, 206, 224; holy 140, 145, 172; Orthodox 143, 147

Felix of Urgel 90, 143

Flasch, K. 2, 9, 13n61, 49, 228

Fleckenstein, J. 86

Flodoard of Rheims 136 
Francia 3, 98, 192; Northern 223; Western 134, 165, 223

Frankish: bishops 173, 229; clerics 106; court 135, 223; divisions 192 ; imperialism 192; kings 56, 228; nation 91; people 92, 104, 227, 230; predecessors 168,171 ; realm 86,227 ; rulers 171; territory 2 ; see also law

free will 74, 106, 137-139, 143-144, 148, $155 n 54$

Fridugisus 106

Ganshof, F. L. 2, 9, 83, 87, 106-107

Garrison, M. 91-92, 111

Gelasius 137, 143, 150-153, 187, 224-225, 228

God: authority of $34,39,41,81,170,198$, 203; blessing of 89; Christian 34, 48, 50, 82-83, 89, 113, 193, 199-200, 202, 205-207, 209-210, 227; city of 2, 90, 94-95, 106, 113, 206; conception of 39; contempt of 34; false 35, 190; the Father 72; heathen 40; in heaven 23; Kingdom of 89; law of $87,104,204,206-207$; love of 55, 87-88, 170, 198, 200, 203; plan of salvation 52; providential plan 4, 36, 54, 70, 81, 83-84, 86, 203, 226; realm of 37 ; revelation of 53 ; Roman 47-48; son of 72, 75, 97; true 37,47 , 50, 53, 55, 93, 191, 198, 200, 230; veneration of 37 ; of vengeance 39 ; will of 85, 87, 98-99, 150, 204, 229; word of 52, 74, 85, 87, 95-97, 114, 145; see also salvation

Gospel 36, 52, 55, 74, 110, 147, 180-181, 203; Homilies 199; of John 180; of Matthew 74, 178

Gottschalk of Orbais 135, 137-139, 143-146, 152-153, 183-184, 225

Gregory the Great 1, 32, 55, 69, 75, 135, 137, 143-144, 149-150, 152, 175, 187, $190,193,199,203,224-225,227$

heathen $32,35,40,50,74,109,190$, 229-230; Babylonian 84; Gods 40; political ethics 209; practices 38; races 101; see also Romans

Hilary 75, 137, 144, 146, 148, 152

Hincmar, Archbishop of Rheims: conception of empire 191; criticism of Charlemagne 173; criticism of Gottschalk's doctrine 145; death 134; ideas on kingship 135; interpretation of Augustine 143; political advice 2,
57; political ethics 4; on predestination $137,146,152-153$; sources 133 ; texts 6, 8, 133-136, 167-168, 187, 192-193; understanding of justice 206

Hippo Regius 22

Holy Scriptures 135, 137, 145-146, 149, $175,185,206,208,210$

Isaac 36,72

Isidore of Seville 1, 32, 55, 69, 75, 108, 111-112, 203-204, 224-225

Israel 35, 87, 91-92, 101, 104, 110, 178-179

Jaspers, K. 33

Jerome 74-75, 144, 149, 187

Jerusalem 89-92, 95, 113-114, 206, 226

Jewish: kingdom 36; nation 35-37; people 35, 190, 202; state 35; ungodliness 97

John the Baptist 98

Jonas of Orléans 55, 203, 224-225

Juno 47-48

Jupiter 47

King Carloman I 3

King Carloman II 134, 182-183

King Charles the Bald 2-4, 7-8, 57, 136$139,144,151,153,165-169,171-173$, 175, 177-186, 191-195, 199-201, 223, 225, 227, 229-230

King Charles the Younger 86-89, 204-205

King David 7, 57, 86-92, 94, 104, 113-114, 133, 135, 149, 168, 172-173, 187, 193, 204-206, 224-225

kingdom (regnum) 9-11, 46-47, 51, 83, 108, 145, 147, 178, 191-192; Charlemagne's 97; of Christ 89, 205; eternal 147; of God 89, 170; heavenly 111; Hebrew 59n36; Jewish 36; Northumbrian 223

King Edwin 105

King Lothar II 137, 139, 144, 148-150, 152-153, 183-184

King Solomon 7, 57, 86-91, 113, 133, 142, 172-173, 187, 205, 224-225

law: Biblical 91; canon 149, 167-168, 175, 206-207; Carolingian 10; civil 149, 167, 207; court 149; divine 25, 33, 56, 179, 202; ecclesiastical 165, 175, 185; eternal 175; Frankish 149; human 152, 174, 207; imperial 152; natural 25, 29n62, 32-33, 55-56, 161n120, 202, 204 ; power of 149 ; procedural 184 ; 
royal 152,174 ; temporal 175,200 ;

Theodosian 171; written 10; see also secular

Louis III 134

Louis the German 144, 183-184

Louis the Pious 149, 183, 224-225, 229

Löwe. H. 106-107

McKitterick, R. 10, 70, 106

Magnus Maximus 38

Manichaeism 22-23, 52

Markus, R. A. 2, 11, 23, 62n75

Martel, Charles 103

Martin, R. 11

medieval: commentators 5; emperor 56, 204; England 106; Frankish kings 56; life 2; political thought 1, 55, 203; texts 108 ; theologians 32 ; treatises 4 ; world 231

Meens, R. 82

Megenfried 96, 98, 116n26

Merovingian 1, 55-56, 86, 171, 203-204

Messiah 35-37

Middle Ages 2, 5, 54, 165

moral 4, 24, 88, 107, 172, 179, 181, 228; approach 136; authority 136, 182, 225; behaviour 36-37, 172; civilisation 51; code 191, 198, 209, 229-230; conduct 3, 152,186 ; criteria 136; failure 136,149 ; guidance 172; ideals 226; improvement 178, 199; institution 229; instruction 182 ; integrity 178 ; issues 4 ; obligation 104; point of view 33, 202; precepts 192; principles 4, 54, 203; standards 4, $33-35,37,192,202,227$; superiority 24 , $34,36,56$; values $5,25,136,201,136$, 201; see also Christian

Morrison, K. F. 49

\section{Nathan 173}

nation $50,81,87,89,101,104-105,108$, 112, 197, 205, 224; Frankish 91; Israel 92; Jewish 35, 37, 202; ruling over 40; warring 36

Nelson, J. L. 2, 10, 53, 106, 191-192, 227-229, 234n56

\section{Orosius 187}

pagan (pagani) 9, 22, 32, 39, 50-51, $56,81,101,106,171,197-198,202$, 229-230; connotation 197; cults 9, 22; leader 208; opposition 49; politicians
$55,190,230$; races 87 ; realms 54,203 ; rulers 32, 209, 230; states 35-37, 48, 51; tyrant 38; vices 197

Passion of Christ 72, 97

Paulinus II of Aquileia 90-91, 114, 137, 143, 168, 171-173

Pepin I of Aquitaine 183, 224

Persians 35, 108, 111

Philo 23

philosophy 24, 86, 91, 196; ancient Greek 187; Aristotelian 28n43, 187; Athenian 72; Ciceronian 209; Epicurean 187; Greek 28n43; Hellenistic 28n43; Platonic 28n43, 187; Stoic 24, 187, 209

Pippin of Herstal 91, 103-104

Platonic 23-24, 28n43, 161n120, 187, 195-196; ideas 24; interpretation of Christianity 26n24; neo- 22-23, 56, 224; principles 24, 207; proverbs 91

Polybius 24, 56

Pope Celestine 140-141, 143, 149, 187

Pope Innocent 142, 149, 187

Pope Leo III 4, 88, 91, 98, 100, 116n26, 205

Pope Nicholas I 139, 184

Pope Stephen II 91

Pope Zacharias 91

power: Christian 99; divine 84, 102 , 105 ; earthly 35,83 ; ecclesiastical 185 ; healing 48; instrument of 8-9; of king 46-47; legitimate 54, 203; military 48, 106, 112, 197, 226; political 9, 111, 189, 191, 197; religious 149; Roman 24-25, 36, 47-48, 56, 84, 102, 105-106, 110, 202, 226; royal 91, 107-108, 151, 228; ruling 4, 83; spiritual 9, 150-153; supreme 40, 48, 83-84, 101-102, 106-107, 113, 134, 151, 226; system of 9; triumphal 87 ; of words 8 ; worldly 32-34, 36-37, 41, 47-48, 56, 81, 101, 105, 113, 193, 202, 226; see also secular

predestination: arguments on 137 ; conditional 138; dispute on 139,144 , 153; doctrine of 137, 139, 144-145, 152 , 154n27, 225; double 137-138, 147-148, 153, 184; of God 148; interpretation of 143; moderate view of 138; public debate over 138, 146; result of 146-147; to salvation 138 ; single 138

prescience 145-148

Prosper of Aquitaine 137-141, 143-148, 152, 176 
Psalms 92, 95, 111, 111, 180-181; Psalm 32, 92, 113, 206; Psalm 48, 94-95; Psalm 58 72-73; Psalm 87 95; Psalm 103 144; Psalm 143 92, 113, 206

Pseudo-Isidorian Decretals 167, 184

Ratramnus (monk of Corbie) 138 redemption 53, 71-73, 97, 100, 138 regnum see kingdom religion 50, 151-152, 171-172; gnostic 23 ; loss of 172 ; priestly 151 ; state 5,40 , 101, 200; see also Christian

ritual 10; coronation 56; of inauguration 2 Romans 24-25, 35-36, 47-48, 56, 84, 102, 107-109, 111, 113, 190, 201-202, 226, 229; classical 51; early 36 ; heathen 22 , 36-37, 40, 48, 55, 161n120, 203; loss of moral values 25; pre-Christian 35, 202

St Paul 22, 29n62, 54, 56, 71-72, 74, 137, 144-146, 149, 178-179, 189, 193, 198, 203, 206, 224, 227

St Peter 145-146, 149, 179

Sallust 24, 28n52, 35-36

salvation 33, 96, 99, 104, 138-139, 151; economy of 52, 96; eternal 55, 62n75, 203; God's plan of 52, 96; history 35 , $53,109-110,190$; of the human race 71 , 97 ; receivers of 35

Schieffer, R. 135

Schrörs, H. 135, 182-183

Scipio 24, 201

secular: affairs 151-152; authority 85 , 136-137, 143, 152, 171, 174, 177, 200, 209, 227, 229; claims 182; court 167, 169, 174; duties 81, 224; figures 149; goods 166 ; history $62 \mathrm{n} 75$; law 149-150, 152-153, 168, 174-175; leader 56, 84, 134, 150, 152-153, 174, 208-210, 226, 230; politics 4, 92; power 2, 4, 7, 34, 54, 99, 109-112, 136, 149-153, 165, 178, 191, 195, 197, 223, 229, 231; property 152; pursuits 55, 190, 229; rulership 191, 195; texts 182; tribunal 169

Sedulius Scottus 225

Semi-Pelagianism 137, 156n70

Seneca 39, 207-208

Sermon on the Mount 54, 195

Skinner, Q. 8, 58n23

Smaragdus of Sain-Mihiel 55, 203, 224 society 9-10, 21, 23, 50, 54, 108, 193; Carolingian 10, 231; disorder in 227; human 23, 55, 203; order in 229; politically organised 11 ; temporal 38 , 171; see also Christian

spiritual: authority 228 ; body 49 ; community 48, 50-51, 58n36, 106, 111; concept 47, 51, 105, 226; connotation $83,86,112$; dependence 107 ; function 151 ; goods 52; groups 50; guidance 228; meaning 48, 106-107, 111, 226; power 9, 150-153; process 150; sense 47; states $34,47,50-51$; veneer 171 ; wisdom 83,102 ; world 33 ; world of light 23

Stoic 24, 72, 187, 207-209; belief 39; doctrine of virtue 24; text 52; tradition 39; see also Cicero; philosophy

subjugation 92-93, 113

Synod: of Aachen 149; of Africa and Orange 138-140; canons 175; of Fismes 135; of Langres 137-139; Mainz 184; of Pîtres 4, 136, 165-166; of Quierzy 138-139, 141, 144; of Savonnières 138-139; of Soissons 184; of Thionville 183; of Toucy 139; of Valence 138-139, 142-144, 153

Testament: New 23, 36, 46, 52-53, 71-72, 84, 96, 111, 203; Old 23, 36, 53, 56-57, $70,72,81,84,88,90-92,101,111$, 113-114, 133, 168, 172, 178, 180, 187, 203-204, 206, 226, 229

theology 73, 76, 133, 140, 142, 144; Carolingian 137; controversy 155; Donatist 23; of history 53; medieval 32; pagan 42n27; political 198; of the saeculum 2; Saxon 137; sense 182 theory: literary 232; political $2,11 \mathrm{n} 8$, $58 \mathrm{n} 36$; of speech acts 8; thoughtprovoking 54

Treaty: peace 105; of Verdun 192 tribes 37, 50, 101, 197, 224; hostile 102; lower-ranking 103; neighbouring 204; subordinate 103, 105; surrounding 87 ; unsubdued 84

Trinity 52, 90; elucidation of the 72; Holy $75,85-86,90$

Tyconius 23, $61 \ln 58$

\section{Valerius 22}

van Oort, J. 2, 23, 26n16, 27n26, 49, $58 \mathrm{n} 36,60 \mathrm{n} 40,61 \mathrm{n} 58$

Varro 35, 42n27

Venus 47

violence 227; legitimacy of 182-183, 189n7; military 227 
Virgil 47-48, 102, 106-108, 224, 226; Aenieid 47, 84, 102, 225, 232n32; hexameter 84-85, 103-104

Wallace-Hadrill, J. M. 2, 12n18, 118n60, $119 \mathrm{n} 62,125 \mathrm{n} 219$

war $35,38,55,85,108,190,194-195$; civil 111; connotations of 106 ; cycle of 106; -fare 195; labour of 84, 104; lawfulness of 227; legitimacy of 227; of the Lord 179; Saxon 13n67; state of 194; unnecessary 170; victories in 84, 191; wage 194-195, 198, 229-230

Wilks, M. J. 2, 30n69, 161n120

Wormald, P. 10 


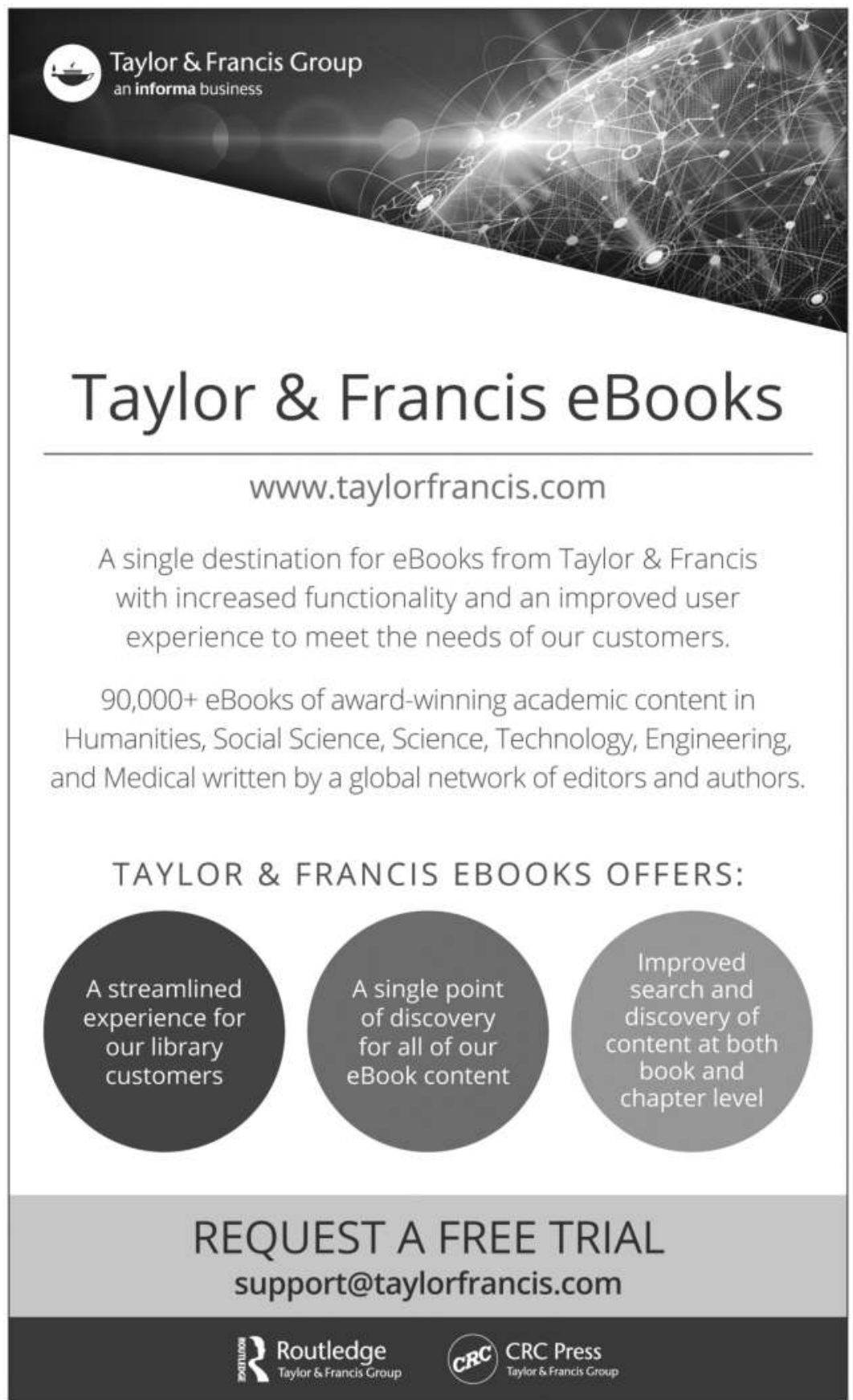

